\title{
Olaj és nyersanyagpiacok makrogazdasági összefüggései
}

Uliha Gábor 
Matematikai Közgazdaságtan és Gazdaságelemzés Tanszék

Témavezető:

Vincze János, DSc

egyetemi tanár

(C) Uliha Gábor 
Budapesti Corvinus Egyetem

Közgazdaságtani Doktori iskola

\section{Olaj és nyersanyagpiacok makrogazdasági összefüggései}

Ph.D. értekezés

Uliha Gábor

Budapest, 2016 



\section{Tartalomjegyzék}

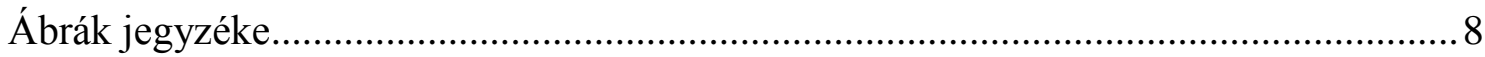

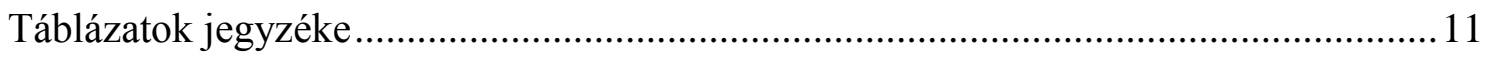

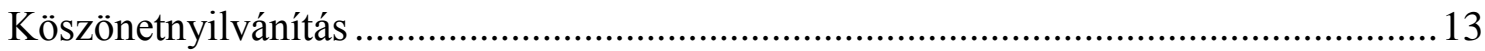

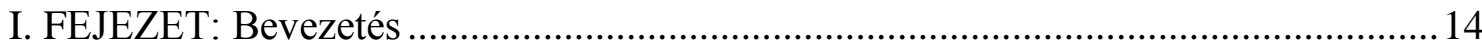

II. FEJEZET: Az olajár gyengülő makrogazdasági hatásai: két versengő elmélet szintézise

II.1.: A vonatkozó szakirodalom áttekintése.............................................................. 17

II.1.1. Olajválság és stagfláció ............................................................................... 18

II.1.2. Mi mozgatja az olaj árát? ............................................................................ 20

II.1.3. Milyen makrogazdasági következményekkel jár az árváltozás?...................24

II.1.4. Mi lehet a csökkenő hatás eredete? …………………………………….......2

II.2.: Az olajár gyengülő makrogazdasági hatásai: két versengő elmélet szintézise ..28

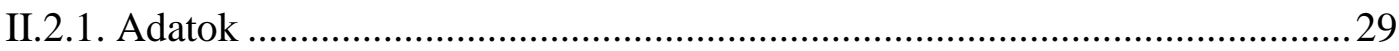

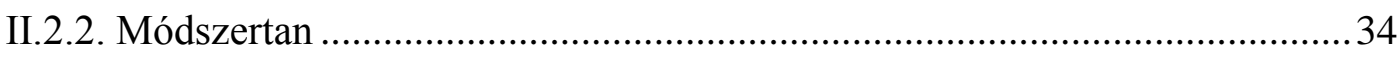

II.2.3. Olajpiaci sokkok makrogazdasági hatásai ....................................................... 39

II.2.4. A makrogazdasági hatások időbeli változása ..................................................47

II.2.5. Robusztusság vizsgálat...............................................................................56

II.2.6. Konklúziók és továbblépési lehetőségek ......................................................62

II.3.: A 2014-ben kezdődő áresés elemzése ………………………………………....65

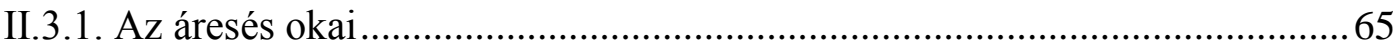

II.3.2. Makrogazdasági hatások ……………………………………………….... 71

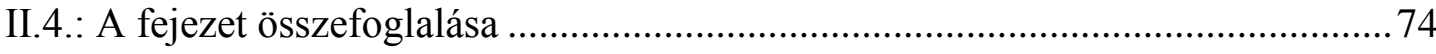

III. FEJEZET: Az olajár és a makrogazdaság kapcsolatának elemzése folytonos wavelet transzformáció segítségével - Svédország és Norvégia példáján ......................................76

III.1. Szakirodalom áttekintése ………………………………………………..........

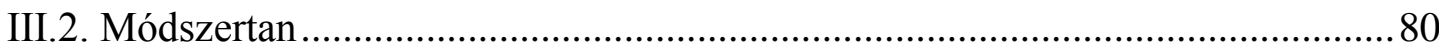




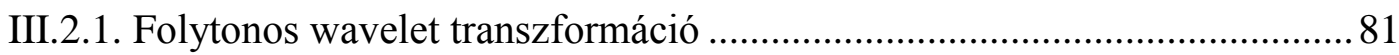

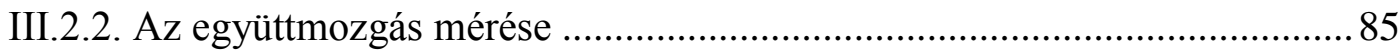

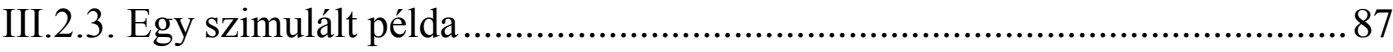

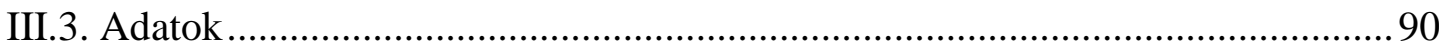

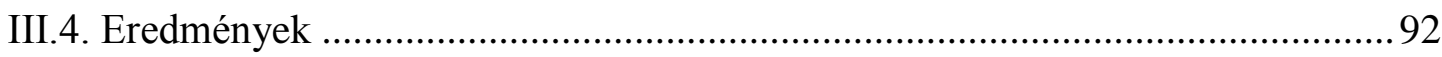

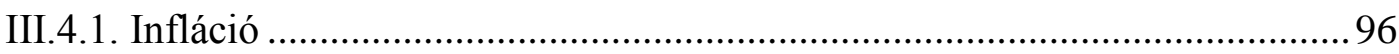

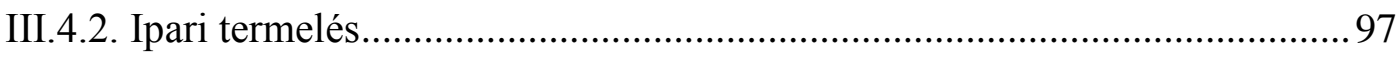

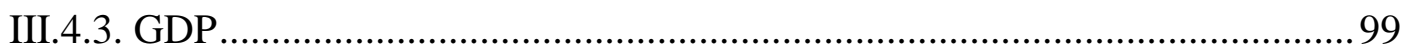

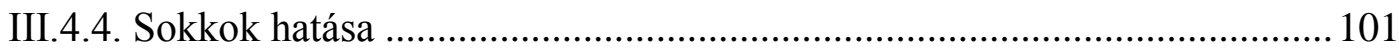

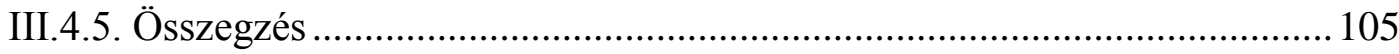

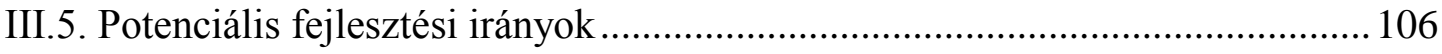

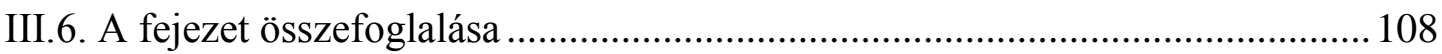

IV. FEJEZET: Rövid távú olajár-előrejelzések teljesítményének stabilitása ................ 109

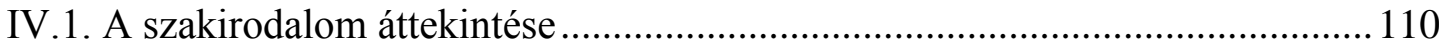

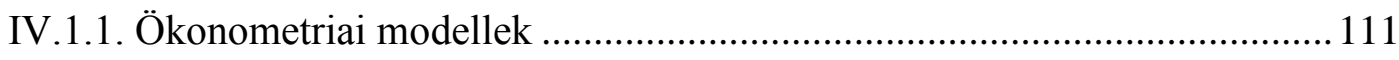

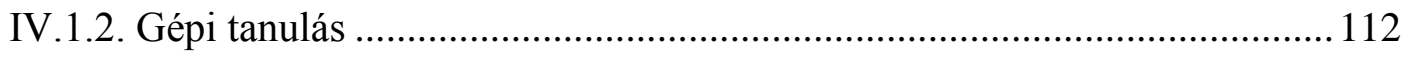

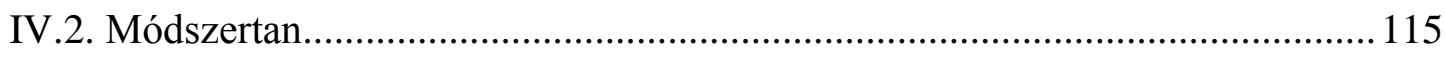

IV.2.1. Heurisztikus modellek - Véletlen bolyongás ..................................... 115

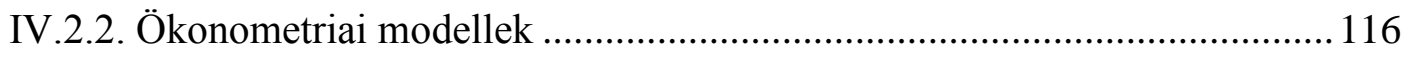

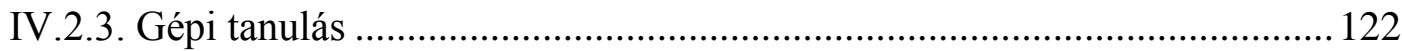

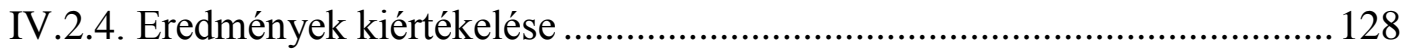

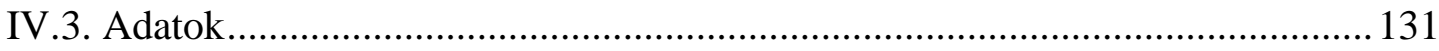

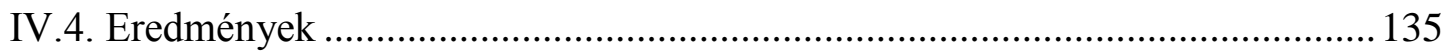

IV.5. Kiegészítés: előzetes szelekció alkalmazása................................................ 144

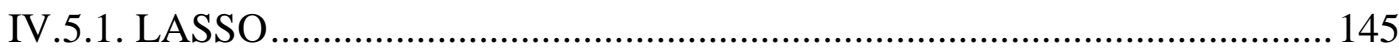

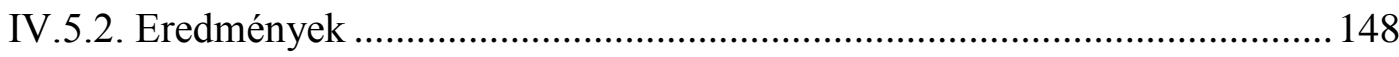

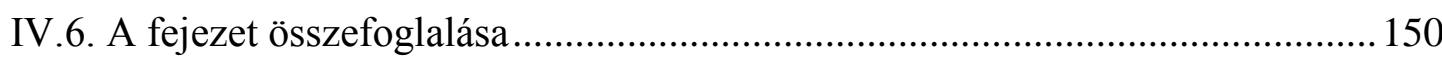




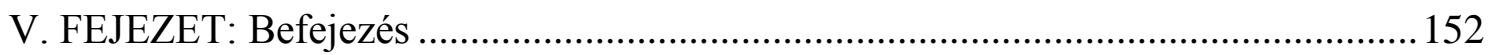

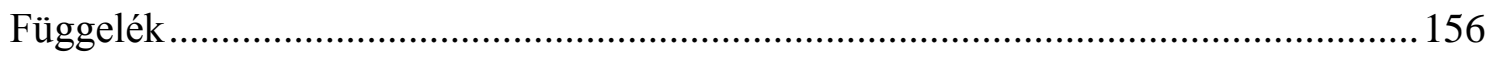

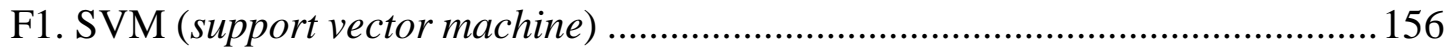

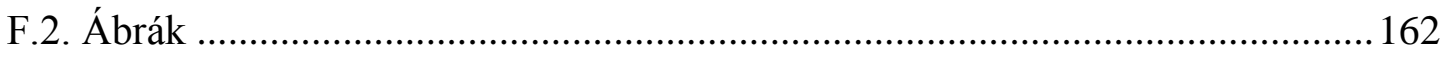

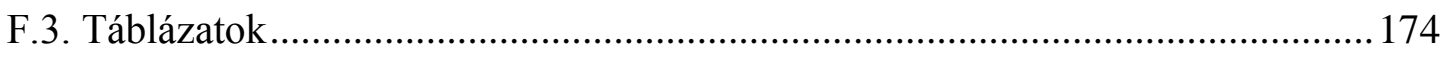

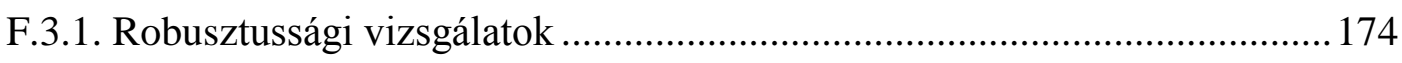

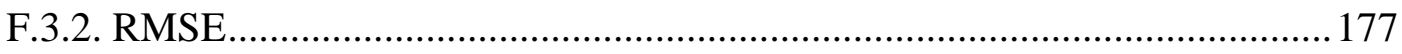

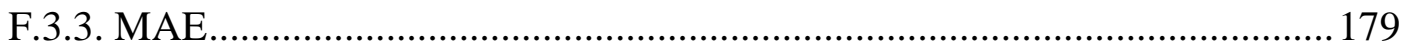

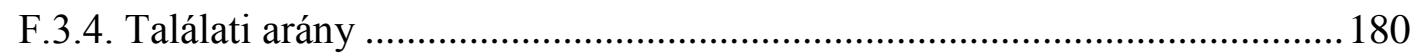

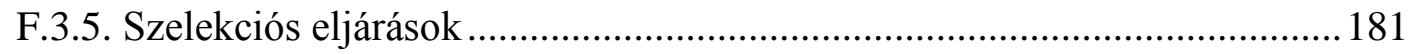

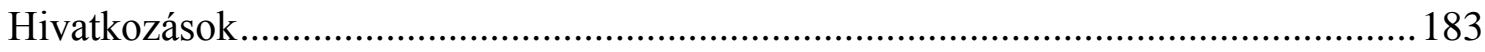

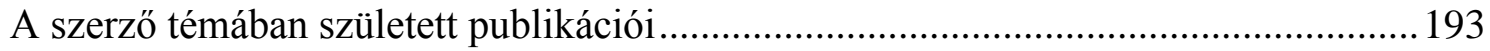




\section{Ábrák jegyzéke}

1. ábra: WTI reálár és az Egyesült Államok makrogazdasági mutatói (1970Q1 - 2014Q4)

2. ábra: A globális nyersolaj-termelés és az amerikai reál olajár idősorai (1973M12014M12). 30

3. ábra: Globális reál aktivitás index (1973M1-2014M12). 31

4. ábra: GDP és munkanélküliségi ráta évesített negyedéves növekedési ütemei (1973Q12014Q4)

5. ábra: CPI és implicit árindex évesített negyedéves növekedési ütemei (1973Q12014Q4)

6. ábra: Impulzus válasz függvények egy szórásnyi sokk esetén, valamint az egy és két standard hibányi konfidencia intervallumok (0-24 hónap).

7. ábra: A sokkok olaj reálárára vonatkozó kumulatív hatása (havi bontás, 1975M12014M12).

8. ábra: A sokkok kumulált hatása az Egyesült Államok makrogazdasági mutatóira (0-12 negyedév) 46

9. ábra: Egységnyi kínálati sokk hatása az Egyesült Államok makrogazdasági mutatóira (időben változó paraméterü modell eredményei).

10. ábra: Egységnyi aggregált keresleti sokk hatása az Egyesült Államok makrogazdasági mutatóira (időben változó paraméterü modell eredményei) 54

11. ábra: Egységnyi specifikus keresleti sokk hatása az Egyesült Államok makrogazdasági mutatóira (időben változó paraméterü modell eredményei) .................55

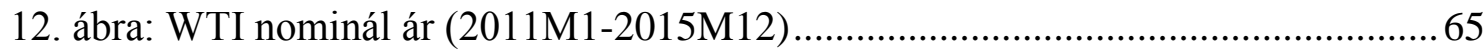

13. ábra: Az Egyesült Államok átlagos napi olajtermelése (1970M1-2015M12) ..........66

14. ábra: Az Egyesült Államok heti kereskedelmi olajkészlete (1982.08.20-2015.12.11.)

15. ábra: Szaúd-Arábia részesedése a világ olajkínálatából (1980-2014) ......................69

16. ábra: Az észak-amerikai palaolaj projektek breakeven árai (2014 ősz).................... 71

17. ábra: A munkanélküliségi ráta változása az Egyesült Államok egyes tagállamaiban

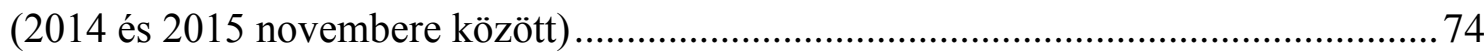

18. ábra: Az idő-frekvencia tulajdonságok összehasonlítása (Rua [2012] alapján) ....... 83

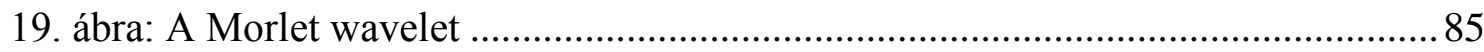

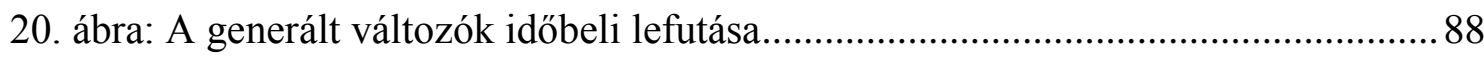

21. ábra: A generált változók wavelet koherenciája és fáziskülönbsége ....................... 90 
22. ábra: Korrelációs mutatók időbeli alakulása és a kétoldali t-próbához tartozó p-értékek

23. ábra: Svéd-norvég, illetve svéd-német wavelet koherenciák alakulása a makrogazdasági változók (CPI, ipari termelés, GDP) viszonylatában .96

24. ábra: A havi CPI infláció és a nominális olajár havi százalékos változásai közti wavelet koherenciák és fáziskülönbségek alakulása Svédország, illetve Norvégia esetében

25. ábra: A reál ipari termelés és a reál olajár havi százalékos változásai közti wavelet koherenciák és fáziskülönbségek alakulása Svédország, illetve Norvégia esetében ......98 26. ábra: A reál ipari termelés és a reál olajár havi százalékos változásai közti parciális wavelet koherenciák és parciális fáziskülönbségek alakulása Svédország, illetve Norvégia esetében, a globális reál aktivitás kiszürése után

27. ábra: A reál GDP és a reál olajár negyedéves százalékos változásai közti wavelet koherenciák és fáziskülönbségek alakulása Svédország, illetve Norvégia esetében .... 100 28. ábra: A reál GDP és a reál olajár negyedéves százalékos változásai közti parciális wavelet koherenciák és parciális fáziskülönbségek alakulása Svédország, illetve Norvégia esetében, a globális reál aktivitás kiszürése után 101

29. ábra: A CPI havi százalékos változása és az olajpiaci sokkok közti wavelet koherenciák alakulása Svédország, illetve Norvégia esetében 103

30. ábra: A reál ipari termelés havi százalékos változása és az olajpiaci sokkok közti wavelet koherenciák alakulása Svédország, illetve Norvégia esetében 104

31. ábra: A reál GDP negyedéves százalékos változása és az olajpiaci sokkok közti wavelet koherenciák alakulása Svédország, illetve Norvégia esetében .....

32. ábra: A makrogazdasági változók és az olajár közti wavelet koherencia alakulása Oroszország esetében 107

33. ábra: A használt előrecsatolt neurális háló sematikus ábrája ............................... 123

34. ábra: Napi WTI spot ár (USD/hordó, 2002.01.02-2014.11.04.) ............................ 133

35. ábra: Benzin és fütőolaj spreadek (2002.01.02-2014.11.04.) …............................. 133

36. ábra: A sokkok kumulált hatása az Egyesült Államok PPI és PCE mutatóira (0-12 negyedév)

37. ábra: Egységnyi sokk kumulált hatása az amerikai PPI indexre (időben változó paraméterü modell eredményei).

38. ábra: Egységnyi sokk kumulált hatása az amerikai PCE indexre (időben változó paraméterü modell eredményei). 164 
39. ábra: Egységnyi sokk kumulált hatása az amerikai CPI-re (Kilian [2009] féle modell eredményei a minta első és második felére külön megbecsülve) 165

40. ábra: Egységnyi sokk kumulált hatása az amerikai GDP-re (Kilian [2009] féle modell eredményei a minta első és második felére külön megbecsülve) 166 41. ábra: Egységnyi sokk kumulált hatása az amerikai implicit árindexre (Kilian [2009] féle modell eredményei a minta első és második felére külön megbecsülve) 167 42. ábra: Egységnyi sokk kumulált hatása az amerikai PCE-re (Kilian [2009] féle modell eredményei a minta első és második felére külön megbecsülve) 168 43. ábra: Egységnyi sokk kumulált hatása az amerikai PPI-re (Kilian [2009] féle modell eredményei a minta első és második felére külön megbecsülve) 169 44. ábra: Egységnyi sokk kumulált hatása az amerikai munkanélküliségi rátára (Kilian [2009] féle modell eredményei a minta első és második felére külön megbecsülve)... 170 45. ábra: Egységnyi kínálati sokk hatása az Egyesült Államok makrogazdasági mutatóira (időben változó paraméterü bővített modell eredményei) 171

46. ábra: Egységnyi aggregált keresleti sokk hatása az Egyesült Államok makrogazdasági mutatóira (időben változó paraméterü bővített modell eredményei) 172

47. ábra: Egységnyi specifikus keresleti sokk hatása az Egyesült Államok makrogazdasági mutatóira (időben változó paraméterű bővített modell eredményei) . 173 


\section{Táblázatok jegyzéke}

1. táblázat: A változók leíró statisztikái és az egységgyök tesztek (ADF) p-értékei ...... 34

2. táblázat: A költségvetési egyensúlyhoz szükséges olajár néhány közel-keleti és északafrikai exportörnél (USD/hordó, nominál). 68

3. táblázat: Az elemzéshez használt változók rendelkezésre állása (felbontás, idősor terjedelme, ország) . ... 91

4. táblázat: Svédország (SWE) és Norvégia (NOR) makrogazdasági mutatóinak leíró statisztikái. .92

5. táblázat: Az előrejelzés során használt modellek összefoglaló táblázata. 115

6. táblázat: A dlog idősorok leíró statisztikái (2002.01.02-2014.11.04.). 134

7. táblázat: A spread [ln(változó)-ln(WTI spot)] idősorok leíró statisztikái (2002.01.022014.11.04.)

8. táblázat: RMSE benchmark értékek (eltolás nélküli véletlen bolyongás, USD/hordó) 136

9. táblázat: MAE benchmark értékek (véletlen bolyongás eltolással, USD/hordó).......136 10. táblázat: Találati arány (DA) benchmark értékek (véletlen bolyongás eltolással, kivéve 2014) 136

11. táblázat: Profit benchmark értékek („buy and hold”, kivéve 2012 és 2014) 136

12. táblázat: A benchmark értékeknél jobban teljesítő modellek aránya az összes modellhez képest.

13. táblázat: A benchmark értékeknél 0, 1, 2, 3 ill. 4 alkalommal (évben) is jobban teljesítő modellek aránya az összes modellen belül 138

14. táblázat: A benchmark értékeknél a legtöbb alkalommal jobban teljesítő modellek halmazának közös része 138

15. táblázat: Az olajszármazék és futures spread modellek találati arányainak jellemző értékei (átlag, medián, 90. percentilis)

16. táblázat: A teljes előrejelzési periódus (2011-2014) alatt a 20 legmagasabb profitmutatót eredményező modell .... 142

17. táblázat: A gépi tanulásos modellek ökonometriai modellekhez mért relatív teljesítménye (mediánok hányadosa) 143

18. táblázat: Illeszkedési mutatók a teljes mintán (2011-2014) 149

19. táblázat: A Kalman-szürőből származó kumulált IVF-ek negyedéves értékeiből számolt átlagok különbsége a minta első és második fele között 174 
20. táblázat: A Kalman-szürőből származó kumulált IVF-ek negyedéves értékeiből számolt lineáris trendparaméter előjele és szignifikanciája ........................................ 175

21. táblázat: Az időben lineáris trend szerint változó hatások indulóértékei................ 176

22. táblázat: Az időben lineáris trend szerint változó hatások trendparaméterei ........... 177

23. táblázat: 1 napos elörejelzések tekintetében az RMSE benchmarkot a legtöbb évben (3 alkalommal) meghaladó modellek. 177

24. táblázat: 2 napos előrejelzések tekintetében az RMSE benchmarkot a legtöbb évben (3 alkalommal) meghaladó modellek. 178

25. táblázat: 3 napos elörejelzések tekintetében az RMSE benchmarkot a legtöbb évben (3 alkalommal) meghaladó modellek. 178

26. táblázat: 1 napos előrejelzések tekintetében a MAE benchmarkot a legtöbb évben (3 alkalommal) meghaladó modellek 179

27. táblázat: 2 napos elörejelzések tekintetében a MAE benchmarkot a legtöbb évben (4 alkalommal) meghaladó modellek 180

28. táblázat: 3 napos előrejelzések tekintetében a MAE benchmarkot a legtöbb évben (4 alkalommal) meghaladó modellek 180

29. táblázat: 1 napos elörejelzések tekintetében a DA benchmarkot a legtöbb évben (4 alkalommal) meghaladó modellek 180

30. táblázat: 2 napos előrejelzések tekintetében a DA benchmarkot a legtöbb évben (4 alkalommal) meghaladó modellek 181

31. táblázat: 3 napos elörejelzések tekintetében a DA benchmarkot a legtöbb évben (3 alkalommal) meghaladó modellek 181

32. táblázat: Illeszkedési mutatók (2011) 181

33. táblázat: Illeszkedési mutatók (2012) 182

34. táblázat: Illeszkedési mutatók (2013) 182

35. táblázat: Illeszkedési mutatók (2014) 182 


\section{Köszönetnyilvánítás}

Köszönet illeti témavezetőmet, Vincze Jánost, a disszertációhoz füzött értékes megjegyzéseiért, az évek során nyújtott segítségéért. Szintén köszönet illeti Várpalotai Viktort, Vonnák Balázst, Szabó-Bakos Esztert, Elek Pétert, Barta Juditot, Varga Balázst, Kucsera Henriket és Badics Milánt a dolgozat alapjául szolgáló cikkek, konferencia tanulmányok értékeléséért, az általuk adott hasznos tanácsokért. A fennmaradó hibákért a felelősség kizárólag engem terhel. 


\section{FEJEZET: Bevezetés}

A disszertáció fejezetei a nyersanyagpiaci folyamatok, azon belül is az olajár alakulása, valamint annak makrogazdasági hatásai köré szerveződnek. Célom, hogy betekintést nyújtsak a nemzetközi szakirodalom kapcsolódó eredményeibe, teszteljem, illetve továbbgondoljam azok főbb konklúzióit. Az egyes fejezetek önálló tanulmányokat képezve külön-külön is olvashatóak.

Az II. fejezetben ${ }^{1}$ körbejárom az olajárak makrogazdasági hatásainak időbeli alakulását, részletesen elemezve a területen született munkák föbb konklúzióit, az azok közötti összefüggések és ellentmondások, tehát a szakmát megosztó viták főbb pontjait. Látni fogjuk, hogy az 1970-es és 1980-as évek stagflációs periódusait a közel-keleti eseményeknek, egészen pontosan az olajtermelés visszaesésének tulajdonító elméletek nem feltétlenül helytállóak, és bár elegáns magyarázatot kínálnak a pénzromlás felgyorsulására, illetve a vele párhuzamosan jelentkező recesszióra, a jelenség mögött komplexebb összefüggések - többek között az amerikai monetáris politikai lépések állhatnak.

Szintén a II. fejezetben mutatom be kvantitatív eszközökkel Kilian [2010], illetve Blanchard és Galí [2007] elméleteinek kompatibilitását. Míg Kilian az olajárak növekedésének alacsonyabb inflációnövelő és kibocsátáscsökkentő hatását az áremelkedést előidéző fundamentumokkal magyarázta, addig Blanchardék az Egyesült Államok (és egyéb, általuk vizsgált nemzetgazdaságok) jobb ellenálló képességét jelölték meg elsődleges okként. A két elmélet összeegyeztethetőségét a Kilian [2009] által kidolgozott modellből nyert olajpiaci (kínálati, aggregált és specifikus keresleti) sokkok makrogazdasági hatásainak időbeli változásával fogom bizonyítani, amihez a Kalmanszürő eljárást veszem igénybe. Végül a 2014 közepén indult áresést és annak lehetséges makrogazdasági következményeit is megvizsgálom a kapcsolódó szakirodalom és saját eredményeim tükrében.

A III. fejezetben Svédország és Norvégia, azaz egy importőr és egy exportőr gazdaság példáján keresztül mutatom be, hogy a klasszikus idősoros megközelítés mellé hasznos

\footnotetext{
${ }^{1}$ A második fejezet Uliha [2012] és Uliha [2016b], a harmadik Uliha [2016a], míg a negyedik Uliha [2015] szerkesztett változata.
} 
kiegészítést nyújthat a folyamatok együttmozgásának frekvenciatérben történő elemzése. A folytonos wavelet transzformáción alapuló eljárások segítségével igazolom, hogy az olajár és a makrogazdasági változók közti együttmozgás sokszor különböző frekvenciákon, és akár ellentétes előjellel valósul meg, így a szimplán az idő dimenzióban történő vizsgálat könnyen vezethet hamis konklúziókhoz. Ebben az esetben is kimutatom a változók közti kapcsolat időbeli módosulását, valamint azt, hogy ok-okozati összefüggések feltáráshoz nem magával az árral, hanem az azt mozgató sokkváltozókkal érdemes dolgozni.

A IV. fejezetben az olajárak rövid távú (1-3 napos) előrejelezhetőségét, valamint a projekciók teljesítőképességének stabilitását tesztelem különböző ökonometriai és gépi tanuláson alapuló modellek segítségével. Az eredményekből kiderül, hogy a legjobban teljesítő modellek halmaza mind az előrejelzési horizont (1, 2 vagy 3 napos előrejelzés), mind a kiértékelési időszak (2011, 2012, 2013 vagy 2014) dimenziójában instabil, nincs univerzális, a többi módszert domináló eljárás. Emellett látni fogjuk, hogy a hibamutató megválasztása is erősen befolyásolja az alkalmazott modellek teljesítőképességének megítélését, illetve az input változók előzetes szelekciója sem oldja meg a teljesítménybeli robusztusság hiányát. 


\section{FEJEZET: Az olajár gyengülő makrogazdasági hatásai: két versengő elmélet szintézise}

Az 1970-es évek két nagy olajválságát követő stagflációs periódusok kialakulását a tankönyvi megközelítés a gazdaságok aggregált kínálati görbéjének módosulásával magyarázza (lásd Mankiw [1999] 274-275. oldal). A levezetés szerint a kőolaj reálárának exogén emelkedése a termelési költségek növelésén keresztül balra tolta az importőr gazdaságok aggregált kínálati görbéjét, ezzel kisebb GDP-t és magasabb munkanélküliséget, illetve árszintet eredményezve. Az 1980-as évek során a kőolaj világpiaci ára korrigált, mégsem következett be globális fellendülés. Ugyanígy elmaradt a világgazdaság élénkülése az ázsiai válság által kiváltott árzuhanás után, mi több, a 2003 tól megindult tartós drágulás sem okozott recessziót és/vagy gyorsuló pénzromlást az importőr országokban. Az olajárak makrogazdasági hatásainak megfigyelt gyengülését számos tényezővel próbálták magyarázni. Az 1980-as évek eseményeit még igazolni látszott az aszimmetrikus hatás hipotézise, amely szerint egy áremelkedés hatása abszolút értékben meghaladja egy ugyanolyan volumenü csökkenését (Mork [1994], Hamilton [2003], Jimenez-Rodriguez és Sanchez [2005], Edelstein és Kilian [2009]). Ez azonban nem ad magyarázatot a 2000 utáni időszakra, amikor az áremelkedés hatása nem - vagy legalábbis sokáig nem - jelentkezett a föbb makrogazdasági mutatókban. A jelenséget megfejteni próbáló tanulmányok egy része a gazdaságok jobb ellenálló képességében (Blanchard és Gali [2007]), mások az olajárváltozás szerkezetében (Kilian [2009], [2010], Bodenstein et al. [2012]) keresték a megoldást. Blanchard és Galí [2007] szerint a 2000-es évekre a technológiai fejlődés (egységnyi GDP előállítása kevesebb kőolaj felhasználását igényelte), a rugalmasabb munkaerőpiac, valamint a hatékonyabb monetáris politika tette lehetővé az Egyesült Államokban - és néhány másik fejlett gazdaságban - a kedvezőtlen makrofolyamatok mérséklődését. Ezzel szemben a Kilian [2010] féle nézet szerint az olajárak exogenitásának feltevése hibás identifikációs stratégiát eredményez, mivel az árak endogén komponense (nemcsak az árak hatnak a makroaggregátumokra, hanem azok is az árakra) miatt az elemzésekben alkalmazott ceteris paribus megkötés a valóságban nem lehetséges. A magas olajárak és a velük párhuzamosan megfigyelt magas infláció például nem feltétlenül áll ok-okozati kapcsolatban egymással, elképzelhető, hogy az aggregált kereslet monetáris politika által generált fellendülése okozza mind az árszínvonal, mind az olajár megugrását (Barsky és 
Kilian [2001]). Kilian [2009] eredményei szerint „,nem minden olajár sokk egyforma”, így az olajpiaci események eltérő szerkezetében kell keresni a változás eredetét. A két olajválság során nem ugyanazok a tényezők okozták az árak emelkedését, mint a 2000es években, amikor a bővülő ázsiai kereslet hajtotta felfelé a jegyzéseket, így az USAban megfigyelt jobb ellenállóképesség valójában az árváltozás szerkezetében (aggregált keresleti sokkok) keresendő. Az olajárak endogenitásának elmélete az elmúlt években széles körben elfogadottá vált, és kétségkívül konzisztens magyarázatot nyújt a stagflációk elmaradására. Ugyanakkor a két elmélet - eltérő forrás, megváltozott gazdasági szerkezet - nem zárja ki egymást, elképzelhető, hogy együtt magyarázzák a megfigyelt jelenséget. Ebben a fejezetben időben változó paraméterű ökönometriai modellek segítségével vizsgálom a hipotézisek kompatibilitását az Egyesült Államok példáján, és megmutatom, hogy nem csupán az árváltozás forrása számít, de bizonyos esetekben a különböző típusú sokkok negatív hatásai is enyhültek az évtizedek folyamán. Annak megválaszolása, hogy az enyhülő hatást a Blanchard és Gali [2007] által megjelölt tényezők okozták-e, nem e dolgozat célja eldönteni, itt csupán a folyamat jelenlétét próbálom igazolni.

Az II. fejezet felépítése a következő. Az első alfejezetben bemutom a témában született főbb kutatási eredményeket, mégpedig a következő témakörök köré szervezve: az olajár mozgását meghatározó tényezők, az árváltozás makrogazdasági hatásai és azok időbeli változása, valamint az utóbbi jelenséget magyarázó elméletek. A második alfejezetben Blanchard és Gali [2007], valamint Kilian [2010] elméleteinek kompatibilitását bizonyítom, a harmadikban pedig azt mutatom be, hogy a szakirodalom és a saját eredményeim alapján mi okozhatta az olajár 2014 közepén indult esését, és ennek milyen következményei lehetnek az OPEC jövőjét, valamint az amerikai és más gazdaságok kilátásait illetően. A negyedikben összefoglalom a fejezet fő következtetéseit.

\section{II.1.: A vonatkozó szakirodalom áttekintése}

Az olajár alakulásának makrogazdasági változókra - különös tekintettel az inflációra és a gazdasági növekedésre - gyakorolt hatása talán a legtöbbbet kutatott kérdés a nyersanyagpiacok és a gazdaság kapcsolatát leíró elemzésekben. Ennek oka az olaj „energiamixen” belüli magas aránya, a piacát jellemző szerkezeti sajátosságok, valamint jelentős geo- és gazdaságpolitikai vonatkozásai. Ebben az alfejezetben a szakirodalom feldolgázásán keresztül mutatom be, miként fejlődött, bővült a területen alkalmazott 
módszerek és elméletek köre, különös tekintettel az olajár mozgását befolyásoló tényezőkre, azok makrogazdasági következményeire és időbeli változására.

\section{II.1.1. Olajválság és stagfláció}

A közgazdaságtan stagflációnak ${ }^{2}$ nevezi azt a jelenséget, amikor a magas inflációs ráta alacsony gazdasági növekedéssel (akár visszaeséssel) és magas munkanélküliséggel jár együtt. Az, hogy mi számít magasnak és alacsonynak nem pontosan definiált, de az 19701980-as években tapasztalt - az olajválságokat követő - gazdasági mutatókat annak szokás tekinteni. Akkor az olajár drasztikus emelkedését okolták a kialakult helyzetért. A 2000-es években aztán újabb árrobbanás szemtanúi lehettünk, a stagfláció azonban elmaradt. A GDP a korábbiaknak megfelelően bővült, az infláció pedig ritkán lépett a monetáris politika által még tolerálható szint fölé, ahogy az 1. ábrán is látható ${ }^{3}$. Ez a jelenség felveti a kérdést: mitől gyengült az olajár makrogazdasági mutatókra gyakorolt hatása? Egyáltalán gyengült-e, vagy talán egészen más okok húzódnak a stagflációk kialakulása mögött, mint amire eddig gondoltunk?

\footnotetext{
${ }^{2}$ A kifejezést elsőként Iain Macleod brit konzervatív politikus használta egy 1965-ös parlamenti beszédében.

${ }^{3}$ Számtalan lehetőség közül lehet választani mind az olajár, mind a makrogazdasági mutatók tekintetében. Mivel az irodalom többsége az Egyesült Államokkal foglalkozik, ezért a tengerentúlon mérvadónak számító West Texas Intermediate olajtípus spot reálárát és az Egyesült Államok GDP és CPI adatait mutatom be. Látható, hogy a két olajválság idején tapasztalt stagfláció nem jelentkezett az új évezred (korábbiakhoz hasonló volumenü) energiaár-emelkedései ellenére sem. Több más nyugati országban is hasonló dinamikák mentek végbe, tehát nem USA-specifikus jelenségröl van szó (lásd Blanchard és Gali [2007]). Az adatok forrása a Federal Reserve Economic Database (FRED).
} 
1. ábra: WTI reálár és az Egyesült Államok makrogazdasági mutatói (1970Q1 2014Q4)

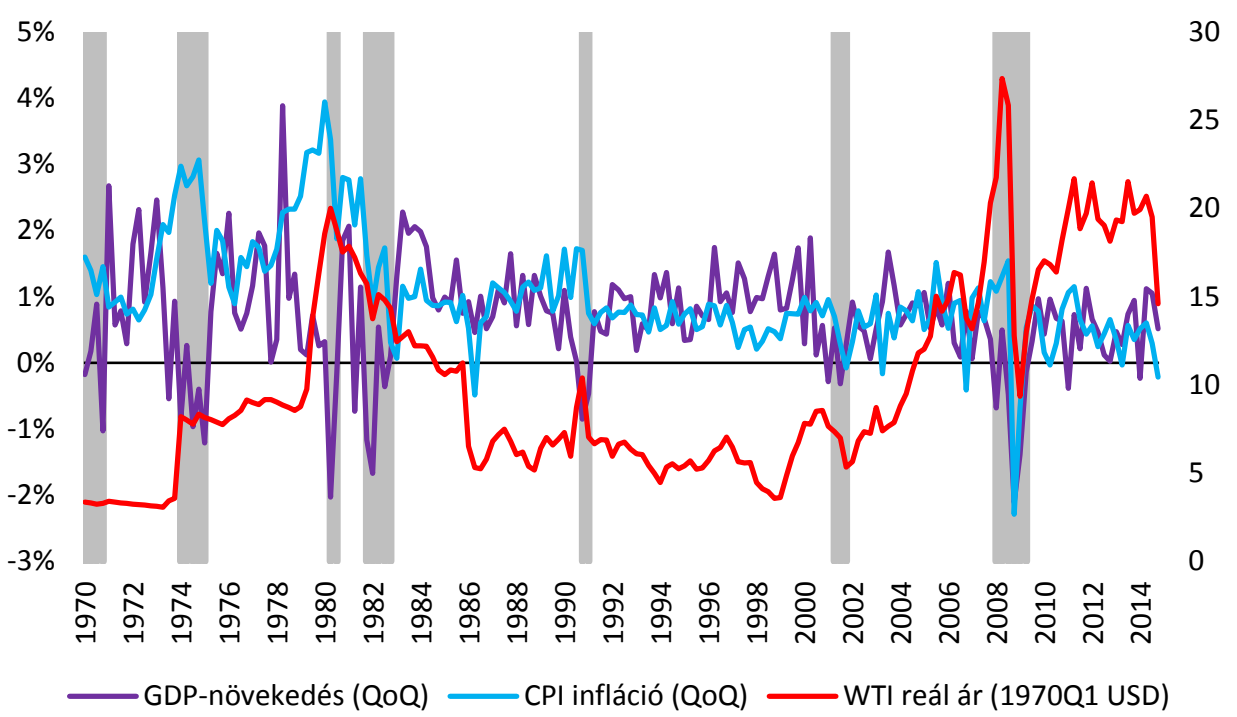

Forrás: FRED.

Megjegyzés: A reál WTI az amerikai GDP-deflátor segítségével állt elő. A szürke sávok az NBER által recesszióként megjelölt időszakokat jelölik.

Az 1973-1974-es majd az 1979-1980-as áremelkedések és az azt követő válságok miatt az olajpiac sokáig a gazdaságpolitika és a közgazdaságtan fó vizsgálati terepeinek egyike volt, azonban a stagflációk elmúltával a kérdés hamar lekerült a napirendről, nagyobb számban csak az ezredforduló után kezdtek újra megjelenni a témával foglalkozó tudományos elemzések. Ezek egy része az árat mozgató tényezők leírásával, másik része annak gazdasági hatásaival foglalkozik. A legfrissebb eredmények pedig arra engednek következtetni, hogy nem az árak változását, hanem azok forrását kell vizsgálni. A témáról jó összefoglalást nyújtanak Barsky és Kilian [2004], Hamilton [2011], illetve Kilian [2014], mely munkákra nagyban támaszkodom az elméletek ismertetésekor.

Azonban még mielőtt belekezdenénk a kutatási eredmények tanulmányozásába, érdemes végiggondolni, hogy a statikus kereslet-kínálati modell ebben az esetben nehezen alkalmazható. A legegyszerübb megközelítés szerint az 1970-es években az OPEC révén a kínálati, a 2000-es években a fejlődő gazdaságok miatt a keresleti függvény tolódott el, mindkét esetben az ár emelkedését előidézve. Ugyanakkor a kőolaj egy kimerülö ${ }^{4}$, raktározható erőforrás, amelynek árát döntően befolyásolják a jövőre vonatkozó

\footnotetext{
${ }^{4}$ A kimerülő erőforrások közgazdaságtanáról lásd Hotelling [1931] klasszikus művét.
} 
várakozások. Ez szükségessé teszi, hogy dinamikus keretben tárgyaljuk a problémát. A helyzetet tovább bonyolítja, hogy az elmúlt négy évtized során a kínálati oldalt nem egymással versengő, árelfogadó termelők alkották, hanem meghatározó szerep jutott egy kartellnek, így az elemzés megköveteli a kifinomultabb módszertani eszközök használatát.

A következőkben az árak „hirtelen” változásainak, a sokkoknak a hatásait vizsgálom, ami elsősorban rövid távú elemzésekre alkalmas ${ }^{5}$. Ha az árban fellelhető trendszerü változásoknak a következményeit szeretnénk kutatni, ahhoz valamelyest eltérő módszertani eszközökre van szükség. Az IMF kiadványa (IMF [2011]) az olaj szükösségéből eredő hosszú távú makrogazdasági hatások bemutatásán keresztül világítja meg ezt a kérdéskört.

\section{II.1.2. Mi mozgatja az olaj árát?}

A lehetséges okok két csoportba sorolhatók: gazdaságiak és nem gazdaságiak. „Nem gazdasági” vagy exogén források alatt az olyan eseményeket értjük, mint az országok közötti vagy országon belüli háborúk, illetve az ezekkel összefüggő, előre nem látható termelésbővítés/szűkítés. Például egyes katonai konfliktusok idején a termelési volumen változása nemcsak abból adódott, hogy a szemben álló felek kitermelése csökkent az olajlétesítményeket érő támadások vagy a logisztikai nehézségek miatt, hanem abból is, hogy más országok - elsősorban a komoly tartalékokkal rendelkező Szaúd-Arábia pótolták a kieső mennyiség egy részét. Egy ilyen lépés mögött több ok is húzódhat. Egyrészt az ellátási bizonytalanságok miatt az importőr országok tartalékok felhalmozásába, a beszerzési források diverzifikálásába, alternatív energiaforrások kiaknázásába és takarékossági intézkedések támogatásába kezdhetnek, ami hosszú távon rontja a termelő gazdaságok piaci pozícióit. Másrészt nem elhanyagolható az a geopolitikai feszültség sem, amely a Közel-Kelet egymással szemben álló hatalmai közt okoz folyamatos problémákat. A legnagyobb tartalékokkal rendelkező Szaúd-Arábia mindig is rászorult az amerikaiak védelmére Irakkal, manapság pedig Iránnal szemben, így előfordulhat, hogy az említett lépéseknek részben biztonságpolitikai magyarázatai

\footnotetext{
${ }^{5}$ A bemutatandó kvantitatív elemzések (SVAR- és DSGE-modellek) a sokkok makrogazdasági hatásait számszerüsítik. Hogy pontosan mit tekintünk sokknak, az mindig a modell felépítésétől, az identifikációs stratégiától függ. Ez persze - mint látni fogjuk - komoly bonyodalmakat, nem ritkán egymásnak ellentmondó eredményeket szül.
} 
vannak (ám ez a kérdéskör messze túlmutat a közgazdasági elemzés határain, így vizsgálatától a továbbiakban eltekintek).

Ezen nem gazdasági események visszavetik a kitermelést, ami a fosszilis tüzelőanyag drágulásához vezet. Kilian [2008] szerint ezek az exogén események az elmúlt 40 évben az 1973-as arab-izraeli háború, az 1973-1974-es olajembargó, az 1978-1979-es iráni forradalom, az 1980-1988-as iraki-iráni háború, az 1990-1991-es Öböl-háború, a 2002-es venezuelai megmozdulások, valamint Irak 2003-as inváziója voltak ${ }^{6}$. Kilian [2008] ugyanakkor ökonometriai módszerek használatával arra a konklúzióra jutott, hogy ezen események csak kevés esetben idéztek elő szignifikáns változást az olaj árában (vagy az USA gazdasági teljesítményében). A kínálat visszaesése marginálisnak tekinthető a piac méreteihez képest, nem utolsósorban a gyakori szaúdi közbelépésnek köszönhetően. Egy másik cikkében Kilian [2009] azt találja, hogy bizonyos esetekben a háborúk okozta bizonytalanság valóban vezethet áremelkedéshez a „biztonsági vásárlásokon” keresztül. Például az Öböl-háború idején jelentősen nőtt annak kockázata, hogy Irak lerohanja Szaúd-Arábiát, és elzárja a csapokat. A szűkös időkre készülve többen előre beszerezték a számukra szükséges mennyiséget, ami áremelkedéshez vezetett. Ez azonban csak közvetve tekinthető exogén - politikai okokra visszavezethető - drágulásnak.

Az árváltozások eredetét ezek szerint inkább a gazdasági körülmények módosulásában kell keresni. Ezek egyike lehet a spekuláció, amit sokan a 2008-as árcsúccsal hoznak összefüggésbe ${ }^{7}$, azonban ennek mértéke, hatása nehezen számszerüsíthető. Itt fontos meghatározni, hogy pontosan mit is értünk spekuláció alatt. Egyrészt annak tekinthetjük az említett biztonsági/elővigyázatossági vásárlásokat, másrészt azokat az ügyleteket, amelyek során a befektetők készletek felhalmozásába kezdenek, hogy a piaci mozgások nyomán nyereséggel adjanak túl a számukra egyébként önmagában haszontalan erőforráson ${ }^{8}$. A készletek felhalmozása alatt nem kizárólag a kőolaj fizikai birtoklását kell érteni. Egy spekuláns határidős ügyletek kötésével vásárolhat nyersanyagot, és még a fizikai leszállítás előtt értékesítheti a rendelkezésre álló mennyiséget. Ebből persze az is

\footnotetext{
${ }^{6}$ Időközben tovább bővülhetett e lista az arab tavasz részét képező líbiai, valamint az Iszlám Állam térnyerését követő iraki és szíriai eseményekkel, illetve az iráni embargóval.

7 Peersman és Stevens [2010] szerint a 2000-es évek áremelkedéseit nagyrészt ez okozta, bár akadnak ellenvélemények is. Kilian [2009] a gyorsuló világgazdasági növekedés generálta többletkereslettel magyarázza a jelenséget.

${ }^{8}$ A spekuláció természetesen az ellenkező irányba is történhet, amikor az árak esését várják.
} 
következik, hogy az ilyen jellegü müveletek a határidős piacon valósulnak meg, és onnan gyürüznek be az azonnali (spot) árakba.

Hamilton [2009a] a 2005-2008 közötti időszak áremelkedéseinek okait kutatva két alternatív hipotézist vizsgált. Az egyik szerint az árakat a fundamentumok hajtották felfelé (növekvő kereslet, stagnáló kínálat), a másik szerint a befektetők által támasztott (nem elővigyázatossági jellegü) spekulációs kereslet. Utóbbi két módon is emelheti az azonnali árat. Egyrészt a magas határidős árak miatt a finomítók hamarabb próbálják beszerezni a termeléshez szükséges mennyiséget, ami növekvő keresletet, következésképp magasabb azonnali árakat eredményez. Emellett a határidős jegyzések emelkedő tendenciája arra ösztönözheti a kitermelöket, hogy csökkentsék a piacra dobott mennyiséget, a jövőben pedig magasabb áron értékesítsék azt (a Hotelling [1931] által leírtaknak megfelelően). Hamilton [2009a] megmutatta, hogy a 2008 júliusában érvényes határidős árak ugyan mutattak némi emelkedő tendenciát az év végéig, de 2009 februárjától már folyamatosan csökkentek. Ez alapján a termelőknek nem állt volna érdekükben visszafogni a felhozatalt ${ }^{9}$. Ami a másik csatornát illeti, Hamilton kimutatta, hogy ebben az esetben a spekulációs hipotézis csak akkor müködhetett, ha az üzemanyagok keresletének árrugalmassága meglehetősen alacsony volt, különben a finomítók irreálisan nagy készleteket halmoztak volna fel. A spekuláció által felhajtott határidős árak a finomítókat vásárlásra ösztönzik, emiatt viszont emelkednek a spot jegyzések, így az üzemanyag ára is. Ha nem nulla az üzemanyag-kereslet árrugalmassága, akkor a fogyasztás visszaesése miatt a finomítói készletek kényszerüen emelkednek (a finomítók nyersolaj iránti kereslete élénkül, miközben üzemanyag-értékesítésük visszaesik). Magas árrugalmasság esetén a készletnövekedés túl nagy lenne egy racionálisan müködő finomító számára. A gondolatkísérlet végeredménye tehát az, hogy a spekulációs hipotézis csak akkor állja meg a helyét, ha feltesszük, hogy az üzemanyagkereslet árrugalmassága eléggé alacsony és a kitermelés nem alkalmazkodott az árváltozásokhoz (azaz stagnált). Ezek azonban megegyeznek a fundamentumok által okozott áremelkedés hipotézisének feltételeivel. Hogy a drágulásból mennyit okozott a spekuláció, és mennyit a fundamentumok változása, ez alapján nem dönthető el,

\footnotetext{
${ }^{9}$ Persze lehet, hogy a termelők nem tekintik megbízható elörejelzésnek a határidős árakat, ebben az esetben viszont a spekulációs kereslet sem okozhatja a kitermelés visszafogását. Ahogy Hamilton [2009a] SzaúdArábia esetén rámutat: a felhozatalt inkább azért fékezték, hogy hosszabb távon, a következő generációknak is jusson az olajvagyonból.
} 
mindenesetre Hamilton szerint a spekuláció önmagában aligha tehető felelőssé a teljes elmozdulásért.

Egy másik lehetséges ok a kartellelméletből olvasható ki. Green és Porter [1984] szerint egy olyan piacon, ahol a kibocsátás csak késve és nehezen figyelhető meg (az olajtermelés tipikusan ilyen), ott a kartellt összetartó erők időben változnak. Alacsony reálkamatláb és gyors gazdasági növekedés mellett az együttműködés ösztönzői dominálnak, viszont dekonjunktúra és magas reálkamatlábak idején a jövőbeli kifizetés jelenértéke alacsony, ezért erősebb a kísértés a kartell szabályainak megszegésére, az eladások növelésére. Nem kizárt, hogy az OPEC működése jól közelíthető ezzel az elméleti modellel. A 2007-2008as pénzügyi válság folyamán előfordult, hogy a hordónkénti 30 dollár közelébe zuhanó nominális árakat a termelés visszatartásával próbálták megfékezni, azonban a bejelentett intézkedéseknek csak töredéke valósult meg: az alacsony bevételek mellett a legtöbb tag nem engedhette meg magának jövedelme további csökkenését (még az esetenként negatív reálkamatlábak ellenére sem). Kérdéses persze, hogy ezt kizárólag a megváltozott világpiaci környezet okozta, vagy talán más (esetleg politikai) folyamatok is szerepet játszottak benne (például a tagországok közötti erőviszonyok módosulásán keresztül). Mindenesetre a modell rávilágít arra, hogy egy kartellt nem lehet tisztán statikus szemléletben vizsgálni ott, ahol a környezet folyamatos mozgásban van. Az OPEC 2015ös látványos „,szétesése” is ezt bizonyítja.

Feldstein [2008] emellett arra hívja fel a figyelmet, hogy az energiahordozó árát dollárban jegyzik, így annak értéke nem érdektelen az exportőrök számára. Ha a dollár leértékelődik, akkor a dollárbevétellel rendelkező termelők reáljövedelme csökken, a keletkező veszteséget pedig az árak emelésével próbálják korrigálni (ezt pedig a keresleti oldal is megengedi, hiszen számukra a gyenge dollár olcsóbb importot eredményez). Ez azonban növeli az USA importkiadásait, így a külkereskedelmi deficit is halmozódik. Utóbbi a valuta további leértékelődését vonja maga után, és az egész kezdődik elölről (multiplikátor hatás). Az árváltozás egy része tehát egyszerűen abból adódik, hogy a termék dollárban, nem pedig más pénznemben denominált. Ez persze elsősorban a nominális árakat érinti, a reálárakra már jóval kisebb befolyása lehet.

Egyesek szerint az említetteknek csak marginális hatásuk volt az olajválságok során, a volatilitást elsősorban a világpiaci kereslet határozta meg. Barsky és Kilian [2001] az 1970-es évek áremelkedéseit az elhibázott amerikai monetáris politikával indokolják. A 
Bretton Woods-i rendszer összeomlása után a Fed expanzív monetáris politikába kezdett, miközben a kormányzat is túlköltekezett. Emiatt növekedett az aggregált kereslet, de nemcsak az USA-ban, hanem a többi fejlett országban is, mivel valutájuk túlzott erősödésétől félve, ők is a monetáris lazítás eszközét választották. Normál esetben a nagyobb kereslet nagyobb árat eredményezett volna, de az olajnál ez másként történt. A nagy termelő vállalatok ekkoriban olyan szerződéseket kötöttek az exportőr országokkal, amelyek szerint adott áron - a technológiai feltételek szabta kereteken belül - annyi kőolajat hozhattak felszínre, amennyit csak akartak, ezért a növekvő keresletet kezdetben nem volt képes megfékezni az emelkedő ár. Az OPEC-országok aztán (érzékelve a megváltozott piaci környezetet) felmondták a számukra elönytelen kontraktusokat, aminek a vége hirtelen áremelkedés és a termelés csökkenése lett. A második olajválság kirobbanása előtt szintén egy globális monetáris expanzió pörgette fel a világgazdaságot, ami a szerzők szerint kiváltotta az újabb áremelkedést.

\section{II.1.3. Milyen makrogazdasági következményekkel jár az árváltozás?}

Az olajárak makrogazdasági hatásait két részre, közvetlen és közvetett csatornákra bonthatjuk (Kilian [2014]). Az olajár emelkedése negatívan hat a GDP-re a háztartások csökkenő elkölthető jövedelmén (Dhawan és Jeske [2008], Bodenstein és Guerrieri [2011]), valamint a vállalatok megnövekedett költségein (Rotemberg és Woodford [1996], Atkeson és Kehoe [1999], Finn [2000]) keresztül. Ezzel párhuzamosan az emelkedő termelési költségek inflációt okoznak, ugyanakkor a háztartási oldalon dezinflációs hatásokat figyelhetünk meg. Az - energiafogyasztáson felüli - elkölthető jövedelem redukálása után az egyéb javak iránti kereslet csökken, és ez a hatás annál erősebb, minél rugalmatlanabb az energia iránti kereslet. Márpedig Kilian és Park [2009] azt találta, hogy az exogén olajár változásokra az energetikai szektorba sorolható amerikai részvények kevésbé érzékenyek, mint azok, amelyek a végső fogyasztástól függnek (kiskereskedelem, turizmus), ami az energiakereslet alacsony árrugalmasságára utal. Az olajárak emelkedésének közvetlen hatásaként tehát csökken ugyan a GDP, az árszínvonal esetén azonban egymással ellentétes hatások nehezítik a tisztánlátást. A közvetett hatások ráadásul tovább bonyolítják a képet.

Ezek a közvetett hatások azért kerültek a közgazdasági elemzések fókuszába, mert a közvetlen csatornák modellbe illesztésével két komoly probléma is akadt. Egyrészt az olajár emelkedése a modellekben nem okozott a vártnak megfelelő nagyságú recessziót 
és inflációt, másrészt nem tudta megmagyarázni, miért nem követte a masszív árcsökkenéseket egy erőteljes gazdasági fellendülés. Az indirekt hatások beépítése némi segítséget nyújtott ezen hiányosságok kiküszöböléséhez. Kilian [2014] összefoglaló tanulmánya három típust nevez meg: allokációs és bizonytalansági hatást, illetve a monetáris politikai választ ${ }^{10}$.

Az allokációs elmélet lényege, hogy a drágulás visszaveti az olajintenzív termékek keresletét, így a gazdaság termelési szerkezetét a relatíve kevés energiával előállítható áruk és szolgáltatások javára módosítja. Ez a strukturális változás számos igazodási költséggel és piaci súrlódással jár, ami végső soron kisebb kibocsátást eredményez (Hamilton [1988]). Ezen felül a humán és a fizikai tőkének bizonyos formáit egyszerüen nem lehet más iparágakban újrahasznosítani, ami elsüllyedt költségekhez vezet (IMF [2011]). A legrosszabb forgatókönyv szerint pedig egy nagyobb csődhullám a banki mérlegeken keresztül a gazdaság más ágazatait is bajba sodorhatja. Könnyen belátható, hogy ez a fajta átcsoportosítási mechanizmus akkor is müködik, amikor az olaj ára csökken, azaz egy nagyobb elmozdulás az energia árában így is, úgy is strukturális átalakulásokhoz vezet, extra költséggel terhelve a gazdaságot. Ez azt jelenti, hogy az aktivitást érintő közvetlen hatásokat - az olajár változásának előjelétől függetlenül - az allokációs hatás negatív irányba korrigálja. Tehát az olajárak növekedése által okozott GDP csökkenést felerősíti, míg az árak mérséklődésének pozitív direkt hatásait részben ellensúlyozza a leírt folyamat.

Ehhez hasonló kimenetet eredményez a bizonytalansági hatás. Bernanke [1983] szerint az olajárak volatilitásának növekedése a reál opciós elmélet értelmében a vállalatokat beruházásaik elhalasztására ösztönzi (feltéve, hogy a kifizetés valamilyen módon függ az olaj árától). Ehhez hasonlóan a háztartások a tartós fogyasztási cikkek beszerzését halasztják el (IMF [2011]). Így összességében az allokációs hatáshoz hasonló folyamatot figyelhetünk meg, a bizonytalanság növekedése erősíti a GDP visszaesését és tompítja annak bővülését.

Bernanke et al. [1997] amellett érvelnek, hogy az olajválságok során a Fed szigorú monetáris politikája nem enyhítette, inkább mélyítette a válságot. Az olajárak növekedésére ugyanis az irányadó ráta emelésével válaszolt, ami tovább fokozta a

\footnotetext{
${ }^{10}$ Megjegyzendő, hogy mindhárom elmélet a reál olajár változásának aszimmetrikus makrogazdasági hatásaira épít, aminek jelenlétére utalnak Mork [1994], illetve Hamilton [2003] eredményei is.
} 
recessziót, ráadásul a lehorgonyzott inflációs várakozások miatt az árszínvonal csak lassan reagált (Bernanke és Gertler [1995]), így egy ideig a gazdaság visszaesését gyors ütemü pénzromlás kísérte (stagfláció). Ezzel szemben fordított esetben kevésbé volt „galamb lelkü” a Nyíltpiaci Bizottság (FOMC), és az olajárak esésénél nem csökkentette olyan mértékben a kamatlábat, mint amennyire korábban - pozitív irányú elmozdulás mellett - megemelte azt. Így Bernanke et al. [1997] szerint a Fed monetáris politikája közvetett módon hozzájárult az olajárak makrogazdasági hatásainak megfigyelt alakulásához. A stagflációk monetáris eredete mellett érvel Barsky és Kilian [2001] is.

A közvetett (aszimmetrikus) hatások elemzése ígéretes iránynak tünt az 1980-as és az 1990-es évek áreséseit követő események, a robusztus gazdasági fellendülés elmaradásának magyarázatára, valamint a stagflációk kialakulásának modellezésére, azonban a 2000-es évek nagy áremelkedéseivel párhuzamos prosperálás már nem fért bele e keretrendszerbe. A reál olajár növekedése nem érintette az amerikai és más importőr gazdaságok GDP és inflációs mutatóit ${ }^{11}$, amelynek okát egyesek a gazdaság jobb ellenálló képességében (Blanchard és Galí [2007]), míg mások az olajárak endogenitásában (Kilian [2009], [2010]) vélték felfedezni.

\section{II.1.4. Mi lehet a csökkenő hatás eredete?}

Blanchard és Galí [2007] VAR modellek segítségével arra a következtetésre jutottak, hogy az USA, Nagy-Britannia, Olaszország, Franciaország és részben Németország esetében is csökkent a GDP-deflátor, a CPI és a bérinfláció, valamint a GDP és a foglalkoztatás olajárra való érzékenysége. A gazdaságok jobb ellenálló képességét négy tényezővel magyarázták. A technológiai fejlődés eredményeképp a termelésben jelentősen csökkent a kőolaj felhasználási hányada, azaz egységnyi reál GDP előállítása kevesebb olajinputot igényelt. A rugalmasabb munkaerő-piacok a sokkokra adott reakcióidőt mérsékelték, és lehetővé tették az optimálishoz közeli kiigazítás elvégzését. A monetáris politikába vetett bizalom növekedése a gazdaságpolitikai beavatkozások hatékonyságát erősítette, a „Great Moderation” utáni évtizedekben az infláció sokkal kevésbé szóródott, a várakozások alacsony és stabil pénzromlási ütem mellett lettek

\footnotetext{
${ }^{11}$ Bár Hamilton [2009a] szerint a 2007 negyedik és 2008 harmadik negyedéve közötti amerikai recesszió magas olajárak hiányában nem alakult volna ki, és az USA lassú, de pozitív GDP növekedést produkált volna. Ezzel cseng egybe Kilian [2010] megállapítása is, aki szerint a pozitív aggregált keresleti sokkok kifutása erősítette a bruttó hazai termék visszaesését.
} 
lehorgonyozva. Emellett Blanchardék megemlítik, hogy korábban más nyersanyagpiacokon is masszív áremelkedések szemtanúi lehettünk, míg a 2000-es években ez elmaradt. Távolabbról nézve azonban ez az állítás nem állja meg a helyét. Ahogy azt később látni fogjuk, a kínai fellendülés fütötte globális növekedés más nyersanyagok keresletét is megemelte ebben a periódusban.

Ezzel szemben Kilian [2010] azzal érvel saját korábbi eredményeire (Kilian [2009]) hivatkozva, hogy nem minden olajár sokk egyforma, és a termelés volumenét érintő kínálati sokkok impulzus válasz függvényei szignifikanciájukat és alakjukat tekintve is eltérnek az áremelkedést okozó keresleti sokkok hatásaitól. Utóbbiaknál a világpiaci aktivitást érő, ezáltal a nyersanyagok összességére ható aggregált, illetve a kifejezetten az olajpiacot érintő specifikus keresleti sokkokat ${ }^{12}$ különböztette meg. Érvelése szerint amit a II.2. alfejezetben egy kibővített mintán és változóhalmazon fogok bemutatni - az eltérő sokkok eltérő makrogazdasági hatásokkal bírnak, és időben folyamatosan változott a reál olajár hullámzását meghatározó tényezők fontossági sorrendje. Ebből következően a 2000-es években azért nem láttunk recessziót, mert a kínai növekedés fütötte nyersanyagár emelkedések negatív hatását a kedvező globális környezet, azaz a gyors világgazdasági növekedés egy darabig ellensúlyozni tudta.

Az olajár változásának strukturális elemzése mára elfogadott eszközzé vált a szakirodalomban. Kilian és Park [2009] az amerikai részvényárak és az olajpiaci sokkok összefüggéseit vizsgálták ${ }^{13}$, Li és Zhao [2011] Kilian modelljét az USA pénzkínálatával bővítették, míg Peersman és Van Robays [2011] 11 országra építettek SVAR modelleket, és becsülték meg a sokkok makrogazdasági hatásait. Anzuini et al. [2014] az Egyesült Államok aktivitási és inflációs idősoraira illesztettek VAR modellt egy kétlépcsős eljárás segítségével, és közelítették a biztonsági vásárlások által kiváltott olajár emelkedés következményeit. Peersman és Stevens [2010], illetve Bodenstein et al. [2012] DSGE keretben elemezték az árváltozás szerkezeti összetevőinek hatásait. Baumeister és

\footnotetext{
${ }^{12}$ Kilian [2009] olajspecifikus keresleti sokk alatt végig elővigyázatossági vásárlásokat ért, de nem világos, hogyan tudja elkülöníteni az elővigyázatossági vásárlást a korábban említett spekulációtól, amit a modell látszólag egyáltalán nem vesz figyelembe. Peersman és Stevens [2010] a kettőt együtt kezeli, és feltételezhető, hogy valójában a Kilian-féle sokk is tartalmazza ezt az elemet.

${ }^{13}$ Ebből kiderült, hogy a sokkok eltérő hatása nem csak a reálgazdasági változók esetében figyelhető meg. Konklúziójuk szerint az 1975-2006-os időszakban a reálhozamok varianciájából mintegy 22\%-ot magyaráztak az olajpiacot érő sokkok, azaz meghatározó szerepük volt a tőzsdei folyamatokban. Emellett rámutattak, hogy egy kínálati sokknak nem volt szignifikáns hatása, míg egy keresleti sokk következményeként nőhettek, csökkenhettek is a hozamok. Elöbbi akkor, ha a sokk az aggregált keresletet, utóbbi akkor, ha a biztonsági vásárlásokat érintette.
} 
Peersman [2012], [2013] pedig időben változó paraméterü modelleket használtak az olajpiaci volatilitásnak és a kínálati sokkok makrogazdasági hatásainak leírására. Utóbbihoz kapcsolódik jelen tanulmány is, hiszen célja, hogy Kilian [2009] modelljéből kiindulva megmutassa a különböző típusú olajpiaci (kínálati, aggregált és specifikus keresleti) sokkok makrogazdasági hatásainak időbeli változását, ezáltal rávilágítson a Blanchard és Gali [2007] elméletével való kompatibilitásra.

\section{II.2.: Az olajár gyengülő makrogazdasági hatásai: két versengő elmélet szintézise}

Az előző alfejezetben leírtak alapján az olajár 2000-es években megfigyelt emelkedését nem követte az olajválságok idején tapasztalt stagflációs periódus, a globális gazdasági bővülés üteme gyors, a pénzromlásé alacsony maradt (legalábbis a fejlett országokban). Az olajár csökkenő makrogazdasági hatásainak lehetséges okairól több elméletet is áttekintettünk, melyek alapján két magyarázat lehetséges:

- Blanchard és Galí [2007] szerint az olajfogyasztás GDP-hez mért hányada az elmúlt 40 évben szignifikánsan csökkent, a munkaerö-piac rugalmasabb lett, és a monetáris politika hatékonysága is javult

- Kilian [2010] szerint az olajpiaci események eltérő szerkezetében kell keresni a változás eredetét, mivel - Kilian [2009] alapján - „nem minden olajár sokk egyforma”, és a két olajválság során nem ugyanazok a tényezők okozták az árak emelkedését, mint a 2000-es években, amikor a bővülö ázsiai kereslet hajtotta felfelé a jegyzéseket

Bár a két megközelítés alapvetően más szempontból vizsgálja a makrogazdasági hatások változását, valójában nem zárják ki egymást, elképzelhető, hogy a kettő együttesen magyarázza a megfigyelt jelenséget. Ebben az alfejezetben arra teszek kísérletet, hogy empirikusan igazoljam a két hipotézis „kiegészítő” kapcsolatát: a gyengülő makrogazdasági hatásokat az olajsokkok eltérő szerkezete, valamint e sokkok makrogazdasági hatásainak időbeli változása közösen okozta.

Az alfejezet felépítése a következő. Az első és második szakaszban a felhasznált adatok és módszerek kerülnek bemutatásra. A harmadikban Kilian [2009] modelljének eredményeit prezentálom egy kibővített mintán és változóhalmazon, míg a negyedikben az olajpiaci sokkok makrogazdasági hatásainak időbeli változását elemzem. Az ötödik 
szakasz tartalmazza a robusztussági vizsgálatokat, míg a hatodik az összefoglalást, a felmerülő problémákat és a potenciális továbblépési irányokat tárgyalja.

\section{II.2.1. Adatok}

$\mathrm{Az}$ elemzés során nyersanyagpiaci és makrogazdasági változókkal dolgozom. A nyersanyagpiaci változók (az olaj világpiaci kínálatának, a világpiaci reál aktivitásnak és az olaj reálárának idősorai) 1973 januárjától 2014 decemberéig terjednek. A kínálati adatok az Energy Information Administration (EIA) adatbázisából ${ }^{14}$ származnak, mértékegységük ezer hordó/nap. Ugyanitt lehet hozzáférni az Egyesült Államok által importált olaj finomítói felvásárlási áraihoz (dollár/hordó), amelyet az amerikai CPI-vel diszkontálva kaptam meg az elemzés során használt reál változót (1974M1-es dollár/hordó) ${ }^{15}$. Mivel a finomítói árak idősorai csak 1974 januárjától állnak rendelkezésre, ezért a megelőző egy év adatait Barsky és Kilian [2001] alapján számoltam vissza. A 2. ábrán az import olaj reálárát és a kínálati idősort találjuk. Látható, hogy az 1980-as évek elején mért csúcsról az OPEC árbefolyásoló erejének csökkenése miatt a jegyzés nagyot esett, és a 2000-es évek elejéig nem is tudott tartósan elmozdulni ebből a helyzetből. Ezt követően egészen a gazdasági válságig emelkedett, onnan megint visszacsúszott, majd 2014 közepéig egy - a korábbi évtizedekhez mérten - magasabb szinten stabilizálódott. A globális nyersolaj-termelés az 1970-es évek végén jelentősen csökkent, és az addigi napi 60 millió hordó helyett mintegy fél évtizeden át az 50-55 millió hordós sávban mozgott. A szaúdiak stratégiaváltása után azonban hirtelen növekedett (ez okozta az árak nagymértékü csökkenését), majd folyamatosan emelkedve 2014 végére 80 millió hordó/nap közelébe került ${ }^{16}$, amit az OPEC-en kívüli termelés felfutása, illetve az ennek következtében megváltozott OPEC stratégia (a piaci részesedés megtartására való törekvés) egyaránt elősegített. Érdekes megfigyelés, hogy kisebbnagyobb megszakításokkal ugyan, de a termelés folyamatosan nőtt, nem jellemezte az árakéhoz hasonló magas volatilitás.

\footnotetext{
${ }^{14} \mathrm{http} / / / w w w . e i a . g o v / p e t r o l e u m /$ data.cfm

15 Blanchard és Galí [2007] a WTI olajfajtát használják, amit az amerikai GDP-deflátor segítségével diszkontálnak. A CPI-t és az importtermék finomítói felvásárlási árait Kilian [2009] alkalmazza. A fogyasztóiár-index előnye, hogy az implicit árindexszel szemben havi bontásban is hozzáférhető.

${ }^{16}$ Gyakran találkozni napi 90 millió hordó fölötti kínálati adatokkal. Az eltérést definícióbeli különbségek magyarázzák.
} 
2. ábra: A globális nyersolaj-termelés és az amerikai reál olajár idősorai (1973M1-

2014M12)

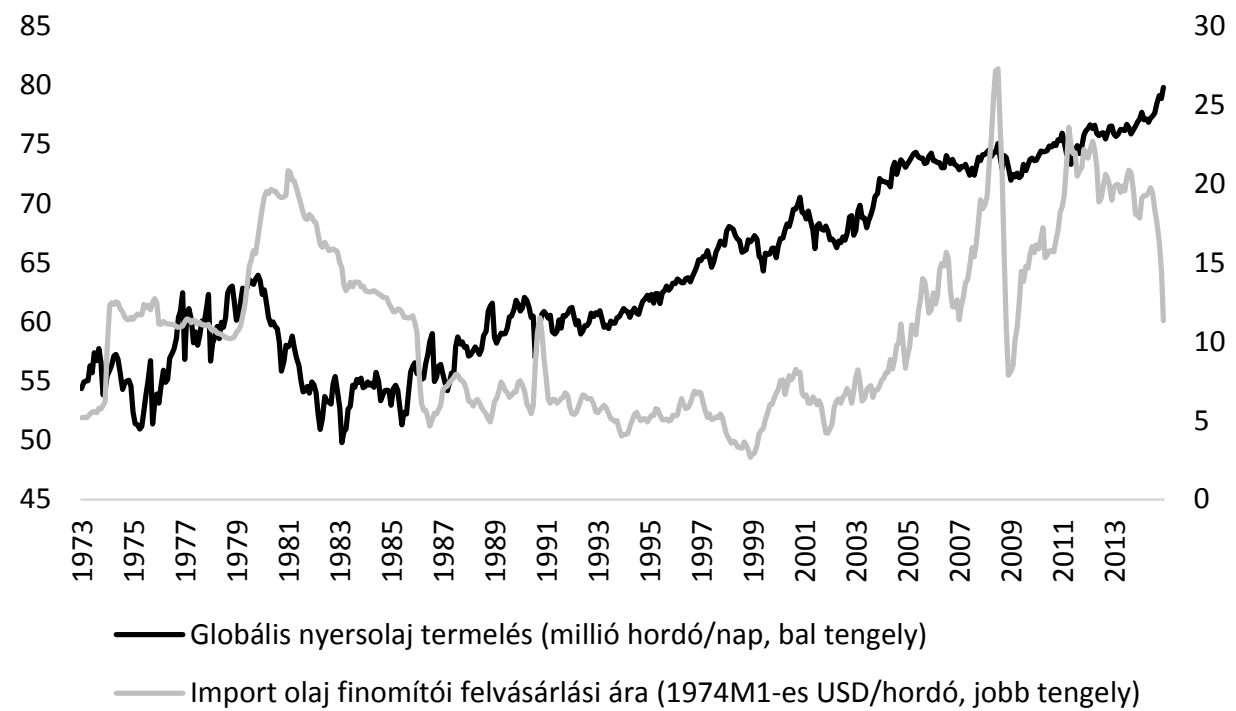

Forrás: EIA (Energy Information Administration).

A világgazdasági reál aktivitás idősorait Lutz Kilian szerkesztette, az adatok az ő honlapjáról származnak, és először Kilian [2009]-ben szerepelnek. Mivel látens változóról van szó, maga a mutató csak egy proxy, ami vízi szállítási adatokból származik, és célja, hogy számszerűsítse a nyersanyagok iránti világpiaci kereslet változását. Ahogy később látni fogjuk, erre azért van szükség, hogy a modellezés során külön lehessen választani az olajkereslet változásait aggregált és specifikus (kizárólag az olajpiacon megjelenő) részre. A globális GDP ugyanis erre nem igazán alkalmas. Egyrészt az árfolyamok kezelése, valamint az eltérő módszerrel számolt GDP-k aggregálása nem triviális feladat, másrészt nem elhanyagolható körülmény, hogy a globális hozzáadott érték változása miből származik, mivel az ipar és a szolgáltatások energiaigénye jelentősen eltér egymástól. A mutató részletes leírása megtalálható Kilian [2009] 1056. oldalán, itt csak annyit érdemes megjegyezni, hogy a száraz rakomány ( $d r y$ cargo) szállítási díjának (freight rate) időbeli alakulásából származik, és logaritmizálás, valamint lineáris trendszürés után alkalmas a ciklikus változások megragadására ${ }^{17} . \mathrm{Az}$ idősor ábrázolásából (3. ábra) kiderül, hogy a két olajválság idején nagy volt a reál aktivitás, azaz nemcsak az olaj, de a többi nyersanyag iránt is megnőtt a kereslet

\footnotetext{
${ }^{17}$ A trendszűrés a technológiai fejlődés árcsökkentő hatása miatt szükséges. Az eredeti idősor emiatt nem stacionárius. Megjegyzendő azonban, hogy a lineáris megközelítés közel egyenletes (és törésmentes) technológiai fejlődést feltételez, aminek teljesülése nem garantált.
} 
(összhangban Barsky és Kilian [2001] megállapításával), és ugyanez látszik 2002-től kezdve. A gazdasági és pénzügyi válság hatására azonban visszaesett a mutató, és a vizsgálati periódus végén ismét a negatív tartományba került, azaz a nyersanyagok iránti kereslet elmaradt a hosszú távú trendtől (ahogy arra egyébként a szén, a földgáz és számos más nyersanyag áresése is utal).

3. ábra: Globális reál aktivitás index (1973M1-2014M12)

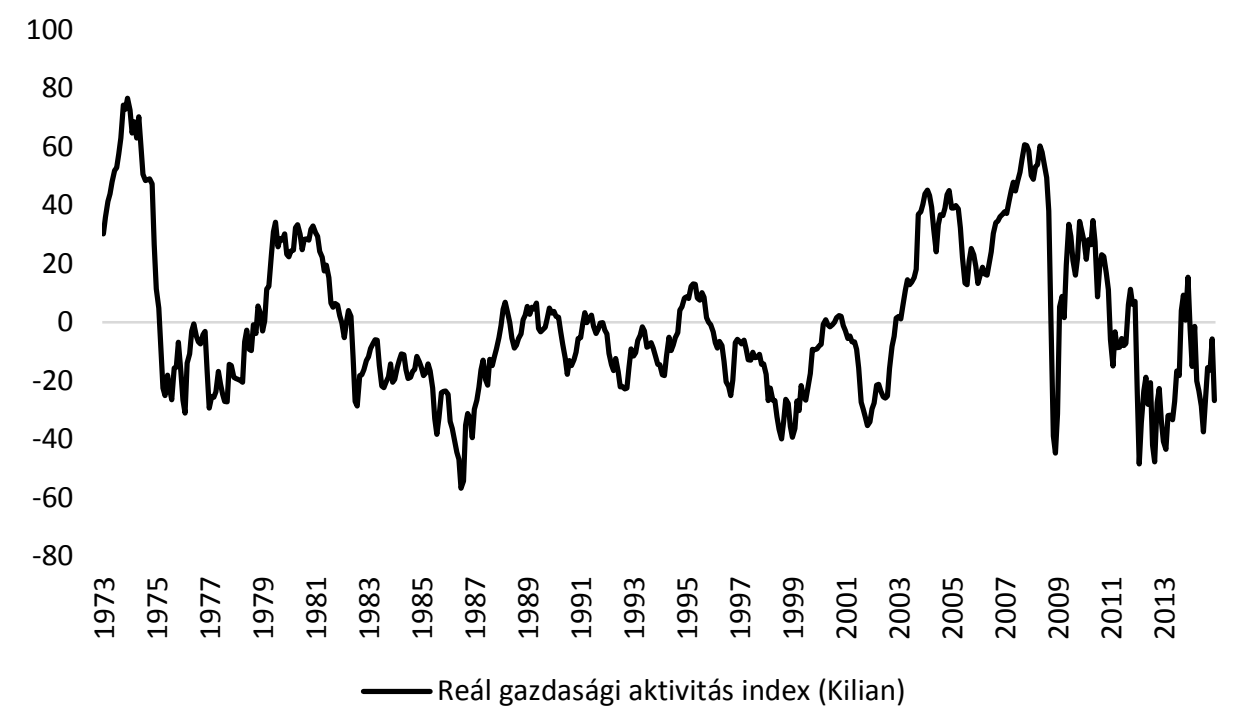

Forrás: http://www-personal.umich.edu/ lkilian/reaupdate.txt

A modellezés során a kitermelés logaritmikus differenciájával, valamint a reál olajár logaritmusával számolok. A kitermelésnél a havi növekedési ütem évesítése is megtörténik, mégpedig a kapott dlog érték 12-vel történő felszorzása révén. A könnyebb értelmezhetőség kedvéért a modellbe mindhárom mutató 100-zal felszorozva kerül, összhangban Kilian [2009] megközelítésével, ami az eredmények összehasonlíthatóságát segíti.

Az olajárak makrogazdasági hatásait négy szezonálisan szürt változón vizsgálom. Ezek sorrendben a 2009-es áron számolt reál GDP, a munkanélküliségi ráta, a fogyasztóiárindex (CPI) és a GDP-deflátor. Mindegyik változó az Egyesült Államokra vonatkozik, és a Federal Reserve adatbázisából származik ${ }^{18}$. A GDP és a GDP-deflátor csak negyedéves, a másik két változó havi frekvencián érhető el, de az elemzésben utóbbiak is negyedéves

\footnotetext{
${ }^{18} \mathrm{https}: / /$ research.stlouisfed.org/fred2/categories
} 
aggregátumként szerepelnek, mégpedig úgy, hogy a kapott változó a negyedév során bekövetkező változást mutassa:

$$
C P I^{Q}=\ln \left(C P I_{M 3}^{Q}\right)-\ln \left(C P I_{M 3}^{Q-1}\right)
$$

Ahol $C P I^{Q}$ a $C P I$ negyedéves aggregátumát, $C P I_{M 3}^{Q}$ az adott negyedév, $C P I_{M 3}^{Q-1}$ pedig az előző negyedév utolsó hónapjára jellemző $C P I$ értéket jelöli. A munkanélküliségi ráta $(U)$ esetén is hasonló az eljárás, de logaritmusok nélkül:

$$
U^{Q}=U_{M 3}^{Q}-U_{M 3}^{Q-1}
$$

A negyedéves növekedési ütemek minden változó esetén felszorzással lettek évesítve. A 4. ábráról leolvasható, hogy a munkanélküliségi ráta kontraciklikus változó, konjunktúra idején csökken, míg dekonjunktúra idején emelkedik. Ennek megfelelően nagyobb pozitív kilengések (a ráta hirtelen emelkedése) a két olajválság mellett az 1980-as és 1990-es évek fordulóján, a 2000-es évek elején (dotcom válság) és 2009-ben figyelhetőek meg. Az utolsó néhány évben az amerikai gazdaság fellendülését a GDP növekedése és a munkanélküliségi ráta csökkenése kísérte.

4. ábra: GDP és munkanélküliségi ráta évesített negyedéves növekedési ütemei (1973Q1-2014Q4)

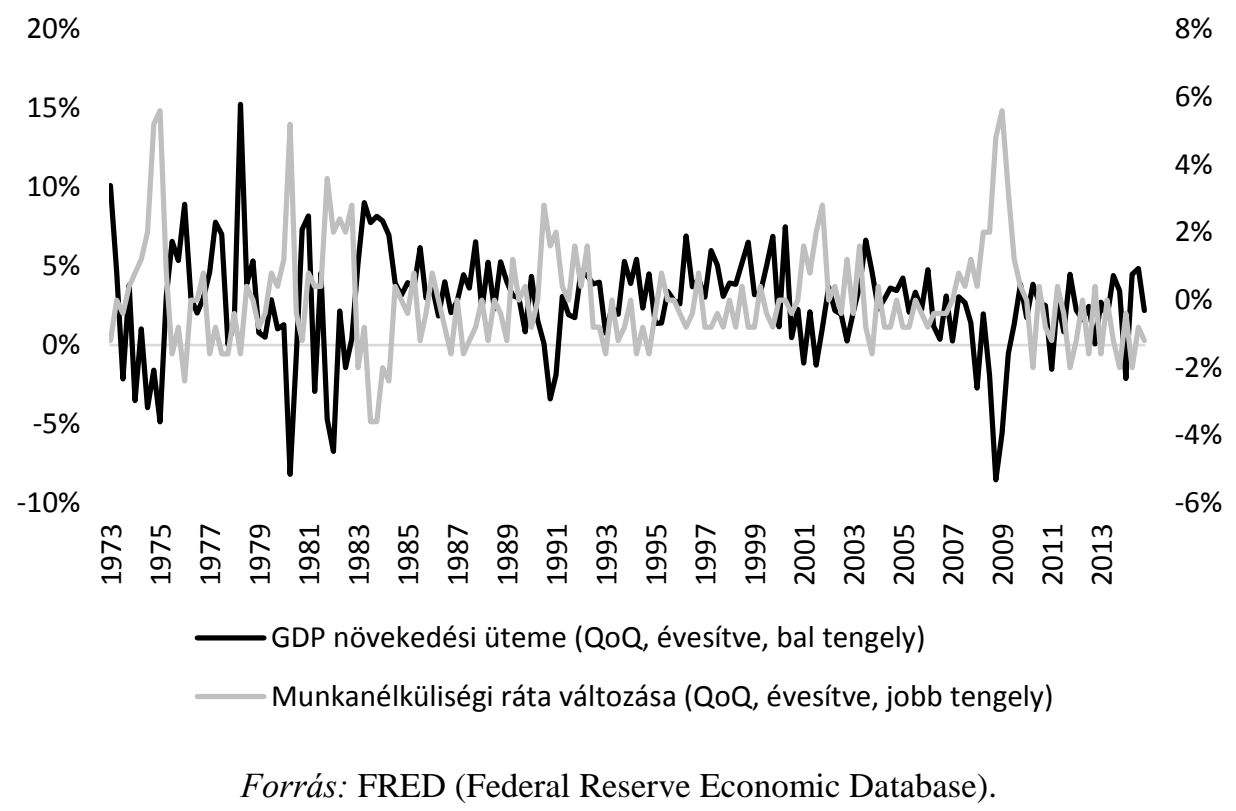


Az inflációs mutatók tekintetében megállapítható, hogy míg az 1980-as évek elejéig magasan tartózkodtak, utána kivétel nélkül stabilizálódtak (Great Moderation), és csak 2008 harmadik negyedévében, illetve az azt követő rövid időszakban láthatunk nagy volatilitást (5. ábra). Ekkor a kibontakozó gazdasági és pénzügyi válság hatására negatív infláció alakult ki, a fogyasztási javak árváltozását mérő CPI egy rövid időre (2008Q4) 10-15\%-os mínuszt is produkált, ami 2,5-4\%-os árcsökkenésnek felel meg egyetlen negyedév alatt. Ehhez hasonló utat járt be a GDP-deflátor is, de jóval kisebb volatilitás mellett. A 2014 utolsó negyedévében tapasztalt visszaesésre gyakori magyarázat az olajárak csökkenése, ám mint arról már szó esett, nemcsak az olaj, hanem más nyersanyagok jegyzése is mérséklődött ebben az időszakban, ráadásul a Federal Reserve is felhagyott a korábbi mennyiségi lazítási programmal, így nem feltétlenül helyes egyetlen tényezőnek tulajdonítani a teljes korrekciót. Erre a II.2.4. szakaszban még visszatérek.

5. ábra: CPI és implicit árindex évesített negyedéves növekedési ütemei (1973Q1-

$$
\text { 2014Q4) }
$$

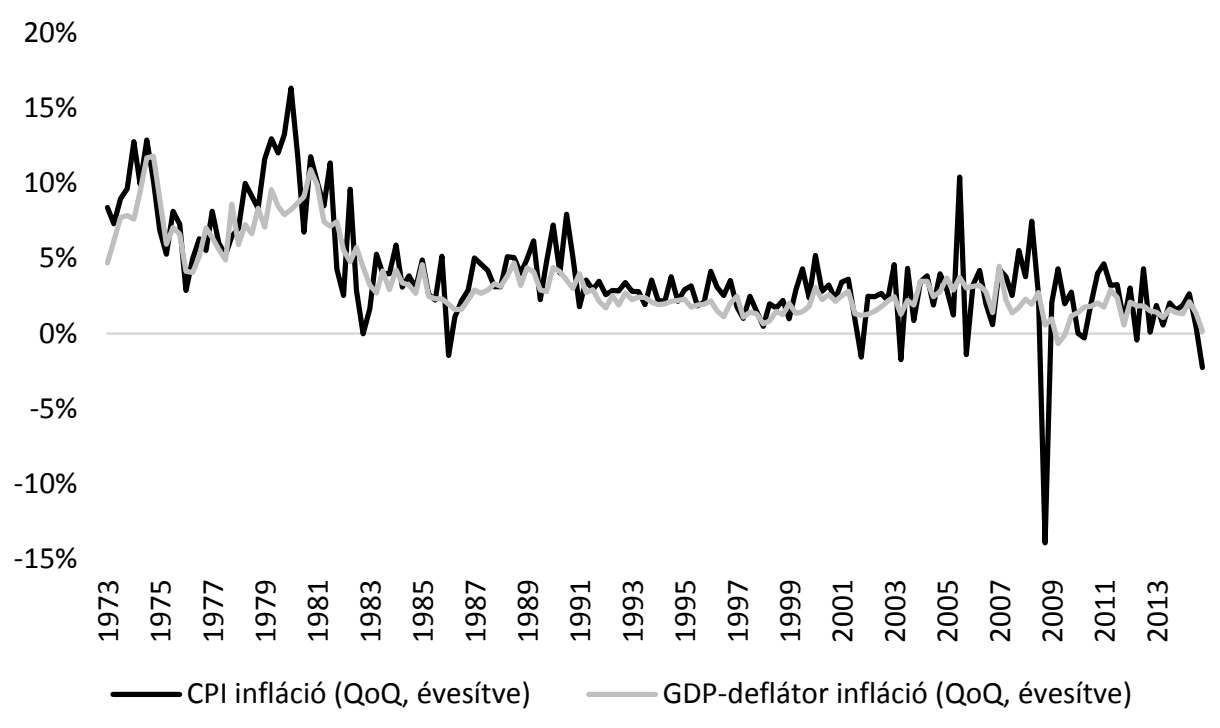

Forrás: FRED (Federal Reserve Economic Database).

Az elemzés során használt vektor-autoregresszív (VAR) modell megköveteli a változók stacionaritását, ezért az 1. táblázat a leíró statisztikák mellett tartalmazza az összes (tehát nemcsak a VAR modellben, de a későbbi vizsgálatokban is használt) idősorokra vonatkozó kiterjesztett Dickey-Fuller (ADF) tesztek eredményeit (MacKinnon [1996]). A nullhipotézis minden esetben az, hogy a folyamat eltolásos véletlen bolyongást követ, 
míg az alternatív hipotézis szerint egy nem nulla várható értékü, stacionárius idősorról van szó. Mind az olajpiaci (termelés, aktivitás, olajár), mind a makrogazdasági változók a korábban bemutatott, transzformált alakban szerepelnek (logaritmikus differencia, évesítés stb.), de míg az első csoportnál havi, addig a másodiknál negyedéves bontásban. A mintaidőszak 1973-tól 2014-ig terjed. Az eredményekből kitűnik, hogy 10\% feletti pérték csupán a GDP-deflátor esetében fordul elő. Ugyanakkor a változó nem szerepel a VAR modellben, így a stacionaritás hiánya sem okoz problémát, ezért újabb transzformáción már nem esik át.

1. táblázat: A változók leíró statisztikái és az egységgyök tesztek (ADF) p-értékei

\begin{tabular}{|c|c|c|c|c|c|c|c|}
\hline & Termelés & Aktivitás & Olajár & CPI & GDP & GDP-defl. & Munkanélküliség \\
\hline Átlag & $0,9 \%$ & 0,26 & 12,67 & $4,1 \%$ & $2,7 \%$ & $3,5 \%$ & $0,0 \%$ \\
\hline Medián & $2,3 \%$ & $-5,27$ & 22,55 & $3,2 \%$ & $3,0 \%$ & $2,6 \%$ & $0,0 \%$ \\
\hline Maximum & $78,0 \%$ & 76,56 & 117,59 & $16,3 \%$ & $15,3 \%$ & $11,8 \%$ & $5,6 \%$ \\
\hline Minimum & $-118,9 \%$ & $-56,71$ & $-114,78$ & $-13,9 \%$ & $-8,5 \%$ & $-0,7 \%$ & $-3,6 \%$ \\
\hline Szórás & $19,0 \%$ & 25,73 & 51,22 & $3,6 \%$ & $3,3 \%$ & $2,5 \%$ & $1,5 \%$ \\
\hline ADF & $0,0 \%$ & $0,8 \%$ & $5,5 \%$ & $5,0 \%$ & $0,0 \%$ & $24,0 \%$ & $0,0 \%$ \\
\hline $\mathbf{N}$ & 503 & 503 & 503 & 168 & 168 & 168 & 168 \\
\hline
\end{tabular}

Megjegyzés: EIA (termelés évesített növekedési üteme, reál olajár logaritmusának 100-szorosa), FRED (évesített CPI és GDP-deflátor infláció, GDP növekedés és a munkanélküliségi ráta változása (százalékpont)), Kilian (reál aktivitási index).

\section{II.2.2. Módszertan}

A bemutatásra kerülő modellek Kilian [2009] cikkére épülnek, ahol az olajpiaci sokkok identifikálása SVAR (strukturális vektor-autoregresszív) modellel történt, Cholesky dekompozíció mellett. A VAR struktúrája a következő ${ }^{19}$ :

$$
A_{0} z_{t}=\alpha+\sum_{i=1}^{24} A_{i} z_{t-i}+\varepsilon_{t}
$$

Ahol $z$ az endogén változók, $\alpha$ a konstansok, $\varepsilon$ pedig az ortogonális és autokorrelálatlan hibák oszlopvektora. A $z$ vektor elemei sorrendben a világpiaci olajtermelés változása (a kitermelési volumenekből logaritmikus differenciával számolva), a világpiaci reál

\footnotetext{
${ }^{19}$ A modell alaposabb leírása megtalálható Kilian [2009] 1058. oldalán.
} 
aktivitás és az olaj reálárának logaritmusa. Az adatok havi bontásúak, a minta 1973 januárjától 2014 decemberéig terjed. A fenti strukturális modell persze közvetlenül nem becsülhető, csak annak redukált változata:

$$
z_{t}=\beta+\sum_{i=1}^{24} B_{i} z_{t-i}+e_{t}
$$

Ahol $\beta=A_{0}^{-1} \alpha, \quad B_{i}=A_{0}^{-1} A_{i}$ és $e_{t}=A_{0}^{-1} \varepsilon_{t}$. Az impulzus válasz függvények generálásához plusz feltevésekre van szükség. Kilian az említett Cholesky dekompozíciót használta identifikációs stratégiának:

$$
e_{t}=\left[\begin{array}{c}
e_{t}^{\text {kitermelési }} \\
e_{t}^{\text {reál aktivitás }} \\
e_{t}^{\text {reálár }}
\end{array}\right]=\left[\begin{array}{ccc}
a_{11} & 0 & 0 \\
a_{21} & a_{22} & 0 \\
a_{31} & a_{23} & a_{33}
\end{array}\right]\left[\begin{array}{c}
\varepsilon_{t}^{\text {kitermelési }} \\
\varepsilon_{t}^{\text {reál aktivitás }} \\
\varepsilon_{t}^{\text {reálár }}
\end{array}\right]
$$

Kilian a kitermelés idősorából származó innovációkat olajkínálati sokkoknak nevezte el, a reál aktivitás innovációjának azon részét, amelyet nem magyaráz a kínálati sokk, aggregált keresleti sokknak hívja (ami az olaj és más nyersanyagok iránt egyidejüleg jelentkező keresletnövekedést takarja), végül az olajár idősorában lévő innovációk azon részét, melyet az előző kettőből egyik sem magyaráz, olajspecifikus keresleti sokk néven definiálja, és az elővigyázatossági vásárlásokkal hozza összefüggésbe. A feltevések szerint a reál aktivitás és az olajár változására a termelők nem tudnak ugyanabban a hónapban reagálni, amit a kitermelési volumen módosításának magas költsége (technológiai akadályok), valamint a bizonytalanság (tartósan magas/alacsony marad-e az ár) magyaráznak. A következő feltevés szerint a világpiaci reál aktivitást is leghamarabb egy hónapos késéssel képes befolyásolni az olaj árának változása. Ezt magyarázhatja a megkötött szerződések miatti rugalmatlanság, illetve konzisztens azzal, amit a reálár és aktivitás idősorok dinamikájában tapasztalunk, hiszen a nagyobb árváltozásokat sosem követte az aktivitás egyidejü elmozdulása. Az ár viszont gyorsan, akár ugyanabban a hónapban képes reagálni a másik két változó mozgására, ami a piac likviditásából és az árak gyors alkalmazkodóképességéből következik. Látható, hogy a havi bontású adatokra azért van szükség, mert negyedéves alapon ez az egyszerü felírás már érvényét vesztené. 
A SVAR OLS-sel egyenletenként becsülhető, a standard hibák pedig Goncalves és Kilian [2004] bootstrap módszere alapján számolhatóak ${ }^{20}$. Innen a sokkok idősorai is kinyerhetőek, így a különböző makrogazdasági aggregátumokra való hatásuk is vizsgálható. Az olajkínálati sokk a termelés változását, az aggregált keresleti sokk nemcsak az olaj, hanem az egyéb nyersanyagok iránti növekvő keresletet, az olajspecifikus keresleti sokk pedig az elővigyázatossági vásárlásokat jellemző innovációkat foglalja magában ${ }^{21}$. Mivel a GDP és az implicit árindex csak negyedéves bontásban hozzáférhető, a makrohatások számszerüsítésénél a sokkok negyedéves átlagával érdemes számolni:

$$
\hat{\xi}_{j t}=\frac{1}{3} \sum_{i=1}^{3} \hat{\varepsilon}_{j t i}
$$

Ahol $\hat{\xi}_{j t}$ a j. típusú (kínálati, aggregált vagy specifikus keresleti) sokk átlagos becsült értéke a t. negyedévben, $\hat{\varepsilon}_{j t i}$ pedig a j. típusú sokk becsült értéke a t. negyedév i. hónapjában $(\mathrm{i}, \mathrm{j}=1,2,3)$. A makrogazdasági idősorok ezután regresszálhatók az exogén sokkokkal, mivel a hibatag és a regresszorok korrelálatlansága miatt a parciális hatások OLS becslése torzítatlan és konzisztens. Az egyenletek bal oldalán a már bemutatott makrogazdasági változók szerepelnek $\left(\Delta y_{t}\right)$, míg a jobb oldalon egy konstans tag $(\delta)$, és a vizsgált sokkhatás 13 negyedévi értéke (az egyidejű illetve a megelőző 3 év sokkjai együtt):

$$
\Delta y_{t}=\delta+\sum_{i=0}^{12} \theta_{i} \hat{\xi}_{j t-i}+u_{t}
$$

Ahol $\theta_{i}$ jelöli a sokknak a függő változóra vonatkozó, i negyedévvel későbbi parciális hatását. A fenti típusú egyenletből összesen 12 becslés készül, a három sokk és a négy makrogazdasági változó összes kombinációját végigpróbálva. Mivel előfordulhat, hogy a

\footnotetext{
${ }^{20}$ A modell becslése MATLAB-ban történt. A Kilian által használt eredeti .m fájlok az American Economic Review honlapján (https://www.aeaweb.org/articles.php?doi=10.1257/aer.99.3.1053) érhetők el. A konfidencia intervallumok számításához 50000 ismétlést használtam.

21 Kilian végig elővigyázatossági vásárlásokat említ, de alighanem ebbe a tagba kerülnek a tágabb értelemben vett spekulációs keresletet érintő sokkhatások is, ha van egyáltalán érdemi szerepük. A témáról lásd bővebben Hamilton [2009a], Peersman és Stevens [2010], Fattouh et al. [2013], Kilian és Murphy [2013], Knittel és Pyndick [2013], Fattouh és Mahadeva [2014], illetve Kilian és Lee [2014].
} 
hibatagoknál autokorreláció lép fel, ezért a konfidencia intervallumok block bootstrap eljárással számolódnak ${ }^{22}$. Hangsúlyozandó, hogy az eljárás a Kilian-féle VAR-ból származó sokkok exogenitására épül, ám elképzelhető, hogy az Egyesült Államok világgazdaságban betöltött szerepe, valamint kiterjedt olajszektora miatt ez nem teljesül, és az egyenletek becslésekor endogenitási probléma lép fel. Például a makrováltozók hatással lehetnek a globális olajpiac müködésére, adott esetben magát a sokkot is kiválthatják. Ennek ellenőrzésére Granger oksági teszteket végeztem, melyekből kiderült, hogy a keresleti sokkok esetén nem áll fenn ilyen probléma ${ }^{23}$. A kínálati sokkoknál azonban más a helyzet. A GDP bővülési ütemének esetében különösen erős a Granger oksági kapcsolat jelenléte, és bizonyos beállítások (késleltetésszám) mellett a GDPdeflátor és a CPI növekedéséről is ugyanez mondható el. Emiatt a kínálati sokkok makrogazdasági hatásaira kapott eredmények fenntartással kezelendők. Szintén a kínálati sokkokkal függ össze egy másik, inkább értelmezésbeli probléma. Amennyiben az elővigyázatossági vásárlások élénkülése egy olyan lehetséges (például katonai konfliktus miatti) termeléskisés miatt történik, ami később valóban bekövetkezik, akkor az árak emelkedését a termelés vagy a várakozások számlájára írjuk? Az első esetben a kínálati sokk becsült hatásaihoz hozzá kell adni az általa kiváltott készletezési kereslet hatásait. Az eredmények értelmezésekor a második megközelítéssel dolgozom, mivel nem lehet egyértelműen eldönteni, hogy a készletezési kereslet felfutásának mekkora része kötődik egy később megvalósuló eseményhez.

Miután Kilian [2009] modelljeit a kibővített adatbázison futtatom, megvizsgálom az olajpiaci sokkok makrogazdasági hatásainak időbeli változását, ami Kilian eredményeit új aspektusba helyezi. Szignifikáns eltérések felfedezése esetén elmondható, hogy a két versengő elmélet (Kilian [2010], illetve Blanchard és Galí [2007]) kompatibilis egymással, és mindkét tényező (eltérő jellegü olajpiaci folyamatok, ellenállóbb makrogazdasági struktúra) szerepet játszott az olajár gyengülő hatásában. Az időben változó paraméterü ökonometriai modellek becslése Kalman-szürő segítségével történik,

\footnotetext{
22 4-es blokkméret és 50000 ismétlés mellett. Az eljárás kezeli az esetleges autokorrelációból adódó torzítást, de nem veszi figyelembe, hogy az egyenlet jobb oldalán generált regresszorok szerepelnek.

${ }^{23}$ A szokásos szignifikancia szintek mellett nem utasíthatók el az „X makrováltozó nem Granger oka az Y sokknak" jellegü nullhipotézisek.
} 
ahol a fenti egyenletek paraméterei a látens változók ${ }^{24}$. A Kalman-szürő lényegében egy állapot-tér modell, ahol az állapot és megfigyelési egyenletek a következő alakot öltik:

$$
\begin{gathered}
v_{t+1}=F v_{t}+\mu_{t+1} \\
z_{t}=G^{T} x_{t}+H^{T} v_{t}+\omega_{t}
\end{gathered}
$$

Ahol $x$ és $z$ a megfigyelhető, $v$ pedig a nem megfigyelhető (látens) változók vektora, míg a $T$ felső index a mátrix transzponáltját jelöli. A $\mu$ és $\omega$ hibatagokról (pontosabban hibavektorokról) felteszem, hogy nulla várható értékü többdimenziós normális eloszlást követnek, és a két egyenlet hibatagjai egymással korrelálatlanok ( $Q$ és $R$ jelölik $\mu$ és $\omega$ kovariancia mátrixait) ${ }^{25}$ :

$$
\left[\begin{array}{c}
\mu_{t} \\
\omega_{t}
\end{array}\right] \sim N\left(\left[\begin{array}{l}
0 \\
0
\end{array}\right],\left[\begin{array}{ll}
Q & 0 \\
0 & R
\end{array}\right]\right)
$$

Az olajpiaci sokkok makrogazdasági hatásainak vizsgálatakor az állapot egyenletek a konstans tagok és a parciális hatások időbeli alakulását foglalják magukba. Itt azzal a feltevéssel élek, hogy a koefficiensek eltolás nélküli véletlen bolyongást követnek. Ennek megfelelően az állapot egyenletek:

$$
\begin{gathered}
\delta_{t+1}=\delta_{t}+\gamma_{t+1} \\
\theta_{i t+1}=\theta_{i t}+\rho_{i t+1}
\end{gathered}
$$

Ahol $\gamma$ és $\rho_{i}$ nulla várható értékü gaussi fehér zajok $(\mathrm{i}=0, . ., 12)$. Azaz a korábbi jelölésekkel $v_{t}=\left[\begin{array}{lllll}\delta_{t} & \theta_{0 t} & \ldots & \theta_{12 t}\end{array}\right]^{T}, \quad F \quad$ a $14 \times 14$-es identitás mátrix és $\mu_{t+1}=$ $\left[\begin{array}{llll}\gamma_{t+1} & \rho_{0 t+1} & \ldots & \rho_{12 t+1}\end{array}\right]^{T}$. A megfigyelési egyenletek az általános forma átírásából jönnek,

\footnotetext{
${ }^{24}$ A Kalman-szürő módszertanának alapos leírása megtalálható Hamilton [1994] 13. fejezetében. A paraméterek becslése rugalmas legkisebb négyzetek módszerével (flexible least squares, FLS) is lehetséges, de ahogy Montana et al. [2009] megmutatták, a két eljárás majdnem ekvivalens. A módszertan hazai alkalmazásaihoz lásd Varga [2011], [2014], Darvas és Varga [2014].

${ }^{25}$ Bár a Kalman-szürő egyik legkedvezőbb tulajdonságának a becslés robusztusságát szokták nevezni, az eloszlással kapcsolatos feltevések változtatása az eredményeket is módosítja. A témáról lásd bővebben Smith és Miller [1986], Meinhold és Singpurwalla [1989], Bradley et al. [1992], illetve Naveau et al. [2005].
} 
mégpedig $z_{t}=\Delta y_{t}, H=\left[1 \hat{\xi}_{j t} \ldots \hat{\xi}_{j t-12}\right]^{T}$ és $\omega_{t}=u_{t}$ behelyettesítés mellett, a $G^{T} x_{t}$ tag elhagyásával:

$$
\Delta y_{t}=\delta_{t}+\sum_{i=0}^{12} \theta_{i t} \hat{\xi}_{j t-i}+u_{t}
$$

Tehát a makrogazdasági hatások becsléséhez használt egyenletek annyiban módosulnak, hogy koefficienseik időben változnak, ugyanakkor a változás nem lehet túl nagy (a paraméterek csak kicsit mozdulhatnak el egyetlen negyedév alatt). A későbbiekben a modellből számított paraméterek simított (smoothed) verzióival dolgozom, melyekből a sokkokhoz tartozó impulzus válasz függvények fognak kirajzolódni. A Kalman-szürőhöz tartozó szimulációkat az EViews 7 programcsomag segítségével végeztem.

\section{II.2.3. Olajpiaci sokkok makrogazdasági hatásai}

A 6. ábra a SVAR modellből származó impulzus válasz függvényeket, illetve az ezekhez tartozó egy és két standard hibányi konfidencia intervallumokat mutatja egy szórásnyi sokk mellett, a bekövetkezést követő 2 évben, havi bontásban. Az eredeti IVF-ek némi módosításon estek át. Az olajkínálati sokkok esetén a szórás mínusz egyszeresével (egy váratlan termeléskieséssel) dolgozom, míg a termelésre vonatkozó hatásoknál az impulzus válasz függvények kumulált alakja szerepel, így mindhárom változó esetén a szintben bekövetkező elmozdulások kerülnek feltüntetésre.

A kínálati sokk termelésre vonatkozó hatása idővel gyengül, ami helyettesítésre utal, azaz más térségekben részben vagy egészben pótolják az így kiesett mennyiséget. A reál aktivitásra és az olaj reálárára vonatkozó hatás azonban inszignifikáns, akár az egy, akár a két standard hibányi konfidencia intervallumot tekintjük. Az eredményekböl következik, hogy a vizsgált periódusban a nem várt termeléskiesés legfeljebb marginális hatással lehetett az olaj reálárára és a világgazdasági aktivitásra (legalábbis az átlagos hatást tekintve).

Ellenben egy aggregált keresleti sokk szignifikánsan növelte a reálárat (időben egyre magasabb szintre tornázva a kurzust) és a kitermelést is befolyásolta, bár utóbbi esetén a két standard hibányi konfidencia intervallum használata mellett nem tapasztalunk nullától 
való szignifikáns eltérést. Ugyanakkor látható, hogy a pontbecslés szerint az első évben a kumulált hatás pozitív, és 7-10 hónappal a sokk bekövetkezése után enyhén szignifikáns, majd lassan a negatív tartományba bukik, és a 17. hónaptól kezdve ismét enyhén szignifikáns lesz. A kezdeti felívelő szakaszt alighanem a nyersanyag iránti növekvő kereslet okozza, az azonban nem egyértelmü, később mitől esik vissza a kínálat, miközben az árak tartósan magasak maradnak. Elképzelhető, hogy a megfejtést a kartellelméletben kell keresni, mivel Green és Porter [1984] eredményei szerint a körülmények változása a kartell viselkedését is módosítja, és „kedvezö környezetben” (a kereslet dinamikus bővülésekor) könnyebb betartatni a szervezet szabályait, és az összprofitot maximalizáló stratégiát követni. Ez jelen esetben a kínálat visszafogását, az árak magas szinten történő stabilizálását jelentheti.

Egy olajspecifikus keresleti sokk az olajtermelést nem, míg a reál aktivitást csak az első pár hónapban élénkíti, az olaj reálárát pedig a bekövetkezés utáni első hónapokban emeli meg a legjobban, utána az alappályától vett eltérés folyamatosan csökken, ellentétben az aggregált keresleti sokknál megfigyelt esettel. Ez arra utal, hogy a kínálat csökkenésének veszélye ritkán tartós, és az elővigyázatossági vásárlások gyors felfutását jellemzően az árak rapid normalizálódása követi. 
6. ábra: Impulzus válasz függvények egy szórásnyi sokk esetén, valamint az egy és két standard hibányi konfidencia intervallumok (0-24 hónap)

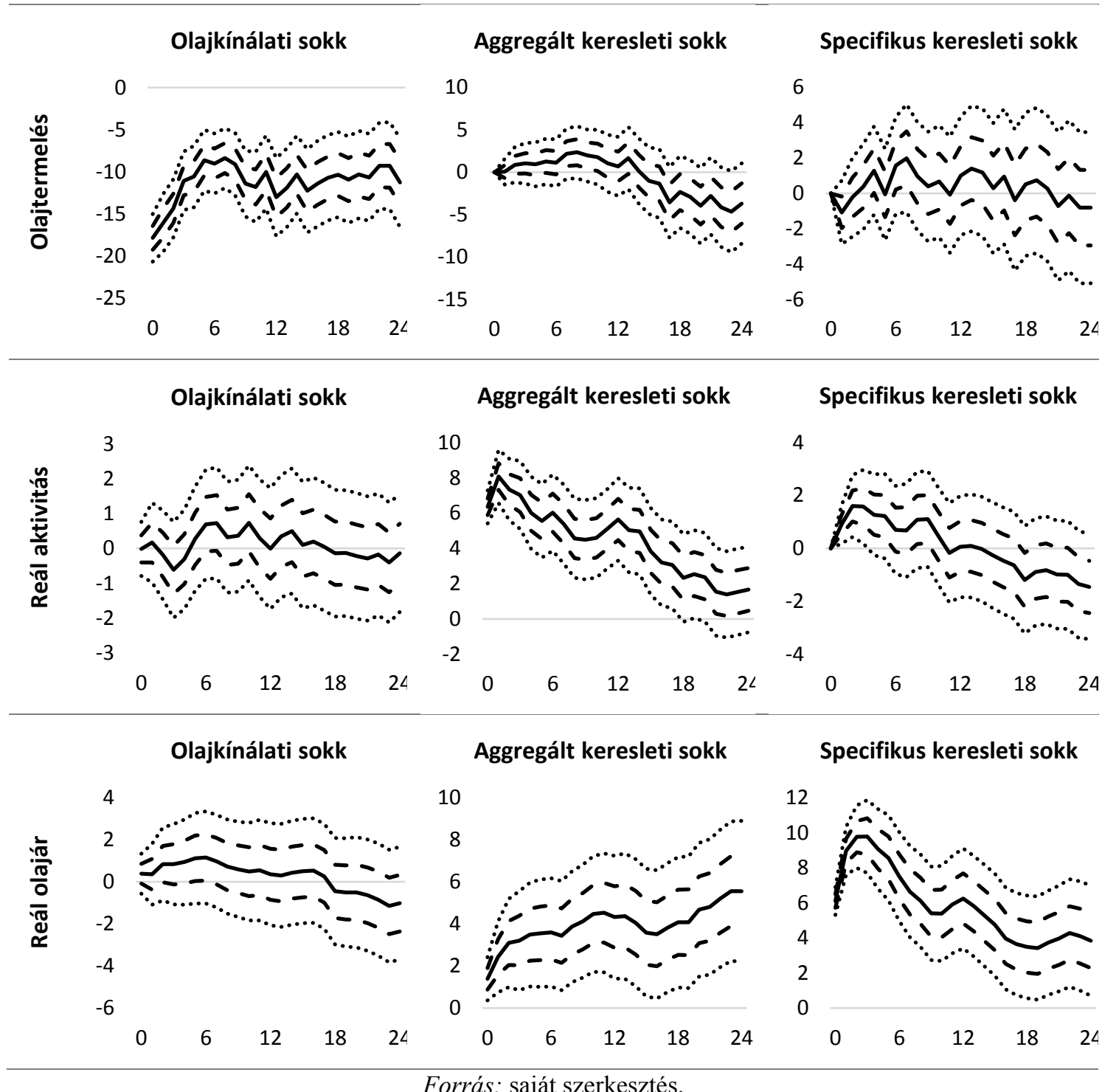

Forrás: saját szerkesztés.

A SVAR eredmények ismeretében kiszámolható, hogy a sokkok milyen mértékben járultak hozzá az olaj reálárának alakulásához az elmúlt évtizedekben (7. ábra, ahol a függőleges tengely a sokkoknak $100 * \ln ($ rpo)-hoz való hozzájárulását méri, ahol rpo az olaj reálára). Ebből kitünik, hogy a vizsgálati periódus alatt az olajkínálati sokkok érdemben nem módosították az árat (összhangban a 6. ábrán látható IVF-fel), ellenben a keresleti sokkok erős befolyást gyakoroltak rá. 1975-től 1979-ig a globális gazdasági lassulás miatt a reál aktivitást érő sokkok összességében csökkentették az olaj reálárát, ugyanakkor látható, hogy már 1977-től kezdve megfordult a trend, az élénkülő kereslet pedig elkezdte ledolgozni a korábbi mínuszokat. Ebben az időszakban a specifikus keresleti sokkok is hozzájárultak a magas árakhoz, ezek azonban rövid periódusok voltak, 
és az 1980-as csúcs (az iráni forradalom és az afganisztáni szovjet beavatkozás) után folyamatosan csökkent a szerepük. Ezután majd másfél évtizeden át a specifikus sokkok hozzájárulása negatív volt, csupán néhány kivételes esemény okozott nagyobb kilengéseket. Ilyen volt az első Öböl-háború, amikor a biztonsági készletezés révén pozitív specifikus keresleti sokkhatás érte a piacot, ez azonban a geopolitikai feszültség enyhülése után azonnal megszünt. Igazi változást a 2000-es évek elejétől, nagyjából 2002-től tapasztalunk, amikor az aggregált keresleti sokkok egészen 2008-ig folyamatosan emelték az olaj reálárát, és csak a válság után, 2010 közepétől fejtettek ki negatív hatást, ami egészen a mintaidőszak végéig kitartott. Ezzel némileg ellentétesen mozgott a specifikus keresleti sokkok kumulatív hatása. A modell szerint ezek visszaesése okozta a pénzügyi/világgazdasági válság során megfigyelt hirtelen áresést, majd támogatta az árak korrekcióját a magasabb tartományokba, ezzel ellentételezve a reál aktivitást érő negatív innovációk befolyását egészen 2014 második feléig. Ekkor a megfigyelt áresés döntő hányada már közvetlenül az olajpiacot érintő sokkok következménye volt. Ez a megfigyelés elsőre talán ellentmondásosnak tünik, mivel a kezdeti árcsökkenést inkább a válság okozta recesszióval, a visszapattanást az abból történő kilábalással, azaz aggregált keresleti sokkokkal, míg az utolsó hónapok zuhanását kínálati elemekkel (amerikai palaolaj termelés felfutása, OPEC stratégiaváltása) magyaráznánk. Azonban a modell eredményei rávilágítanak e hipotézis helytelenségére. Jól látható ugyanis, hogy a reál aktivitás kumulatív hatása a teljes mintán lassan, egyenletesen változott, miközben a specifikus kereslet hozzájárulása akár néhány hónap alatt nagy elmozdulásokat tudott produkálni. Az olajárba gyorsan beépülnek az információk: a rossz makrogazdasági kilátások önmagukban elegek ahhoz, hogy lenyomják a határidős árakat, onnan pedig a csökkenés átgyürüzik az azonnali piacokra (illetve a rövid lejáratú szállítások díjszabásába). Így az olajár 2008-2009 során látható visszaesése csak részben tekinthető az akkor már lassuló globális növekedés eredményének, azt jórészt a kilátások romlása, a jövőbeli kereslet csökkenése okozta, mégpedig a biztonsági jellegű vásárlások mérséklődésén keresztül. Mikor elkezdődött a válságból való kilábalás, az emelkedő árakra vonatkozó várakozások és az arab tavasz eseményei pozitív specifikus keresleti sokkokat generáltak, melyek a hosszú távú trend alá bukó reál aktivitás negatív hatását ellensúlyozva elérték, hogy az olajár visszaemelkedjen a korábbi szintek közelébe. Ezt az ellátási bizonytalanságot törte meg, amikor a nem konvencionális kitermelés volumene az OPEC fontosabb szereplöit, 
elsősorban Szaúd-Arábiát a piaci részesedés megtartására, a kitermelés növelésére ösztönözte.

7. ábra: A sokkok olaj reálárára vonatkozó kumulatív hatása (havi bontás, 1975M12014M12)

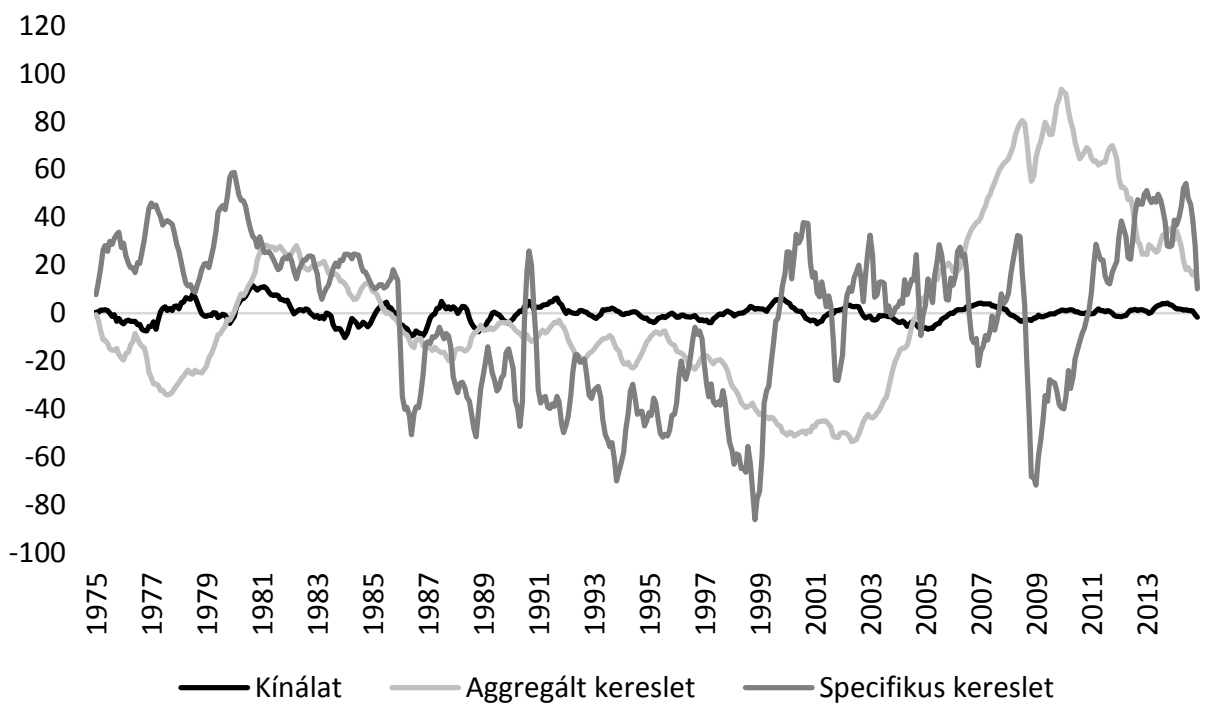

Forrás: saját szerkesztés (a reál olajár logaritmusához való hozzájárulás a VAR modellszámítások alapján).

A modellből nyert sokkváltozók idősorai már alkalmasak a makrogazdasági hatások elemzésére. Az IVF minden esetben az egyenletek becsült paramétereinek sorozata, aminek kumulált változata adja a szintben bekövetkezett változásokat. A könnyebb értelmezhetőség kedvéért olajkínálati sokk alatt ezúttal is a termelés visszaesése értendő. $\mathrm{Az}$ eredményeket a 8. ábra foglalja össze, minden blokkban az oszlop szerinti sokk egységnyi változásának a sor szerinti makrogazdasági változóra vonatkozó hatása (az alappályától vett százalékos, munkanélküliségi ráta esetén százalékpontos eltérése), valamint a kumulált IVF-hez tartozó egy és két standard hibányi konfidencia intervallumok szerepelnek a sokk bekövetkezése óta eltelt idő függvényében.

Két standard hibányi konfidencia intervallum használata mellett arra a megállapításra jutunk, hogy egy kínálati sokk csupán a munkanélküliségi rátát képes szignifikánsan megemelni, azt is csak a bekövetkezés után 1-3 negyedévvel. Amennyiben a megengedőbb egy standard hibányi konfidencia intervallummal dolgozunk, akkor a munkanélküliséget növelő hatás a 3 év alatt végig kitart, és egy rövid ideig tartó gazdasági visszaeséssel (0-2. negyedévben a GDP szignifikánsan az alappálya alá bukik), illetve 
némi inflációval párosul. Utóbbi kapcsán érdemes megjegyezni, hogy míg a CPI alappályától vett eltérése nagyjából a bekövetkezés után 6 negyedévvel válik inszignifikánssá, addig ugyanehhez a GDP-deflátornak 10 negyedévre van szüksége. A maximális eltérés a sokk bekövetkezése után 1-1,5 évvel alakul ki, onnantól kezdve mind a CPI, mind a GDP-deflátor pontbecslése korrigál. Az egy standard hiba használata melletti elemzés persze nem feltétlenül meggyőző. Perotti [2012] más munkák kapcsán megjegyzi, hogy a közgazdasági alkalmazásokban talán csak azért terjedt el ennyire az egy standard hibányi konfidencia intervallum használata, mert két standard hiba mellett a levont konklúziók jelentős hányada már érvényét veszítené. Összességében tehát nincs meggyőző bizonyíték arra, hogy az Egyesült Államokban az olajkínálati sokkok komoly recessziós és inflációs hatással bírtak volna az elmúlt évtizedekben, egyedül a munkanélküliségi rátánál tapasztalni egy rövid ideig tartó szignifikáns emelkedést.

Az aggregált keresleti sokk ezzel szemben már mind a négy makrováltozó esetén szignifikáns eltérést eredményez a sokk nélküli esethez képest. Az árindexek folyamatosan emelkedve, nagyságrendileg 1,5-2 év után érik el a maximális különbséget, majd utána enyhén korrigálnak. Egy standard hibányi konfidencia intervallum mellett az eltérés a 3 év egészében szignifikáns, és CPI esetén a sokk bekövetkezése után 2-9 negyedévvel még két standard hiba mellett is az marad. A GDP-deflátornál a vízszintes tengely a konfidencia intervallum határán helyezkedik el, azaz ekkor is van némi statisztikailag kimutatható inflációs hatás. Ennek oka, hogy az aggregált keresleti sokk az olaj árát tartósan emeli (6. ábra), illetve egyéb nyersanyagoknál is drágulás figyelhető meg, ami az amerikai árindexek növekedésével jár. Ez idővel a reálgazdasági mutatókat is negatívan érinti, ám kezdetben e hatás nem érvényesül. Az első negyedévekben a pontbecslés még a GDP növekedését, a munkanélküliség esését jelzi (bár szignifikáns eltérésről itt nem beszélhetünk), valamikor a második év során azonban a magasan ragadt nyersanyag árak negatív hatása kezd dominálni, és az alappályához képest tartósan magasabb munkanélküliségre és alacsonyabb GDP-re lehet számítani. Kilian [2010] erre a dinamikára utalva állította, hogy (Hamilton [2009a] eredményeivel összhangban) a magas olajárak végülis hozzájárultak a recesszió kialakulásához, mivel a 2003-2008 közötti áremelkedést okozó, folyamatosan jelentkező aggregált keresleti sokkok pozitív rövid távú hatása egy darabig segítette a gyors gazdasági növekedés fennmaradását, azonban a sokkok megszünésével ez az ellensúly megszünt, és a hosszabb távú negatív hatás tudott érvényesülni. 
A 6. ábrán látható volt, hogy egy specifikus keresleti sokk az olaj reálárára az első negyedévekben fejti ki a legnagyobb hatást. Ennek következtében a CPI-t is csak a bekövetkezés után fél évig tudja szignifikánsan az alappálya fölé lökni, míg a GDPdeflátornál az eltérés statisztikailag nem különbözik nullától ${ }^{26}$. A reálgazdasági változóknál nincs lassulásra (magasabb munkanélküliségre, illetve alacsonyabb GDP-re) utaló jel. Ez azt sugallja, hogy a 2008-2009-es válságból való kilábalás alatt az Egyesült Államok gazdaságát nem hátráltatta a specifikus sokkok miatti olajár emelkedés. Sőt, ha csak a pontbecslést nézzük, akár még hozzá is járulhatott a munkanélküliség csökkenéséhez. Ezt magyarázhatja az amerikai olajtermelés felfutása, megjegyzendő azonban, hogy az IVF a teljes mintaidőszakra jellemző átlagos értéket mutatja, míg a palaolaj forradalom csak az utóbbi 5 évben tudott meghatározó tényezővé válni. Azaz könnyen elképzelhető, hogy a sokkok makrogazdasági hatásai a vizsgálati periódus alatt jelentős változáson mentek keresztül, és a teljes időszakra vonatkozó átlag valójában eltérő viselkedésű éveket/évtizedeket mos egybe. Ezt a lehetőséget elemzem a következő szakaszban.

${ }^{26}$ Egy standard hibányi konfidencia intervallum használata mellett már a vizsgált 3 év egésze alatt kimutatható a különbség. 
8. ábra: A sokkok kumulált hatása az Egyesült Államok makrogazdasági mutatóira (012 negyedév)
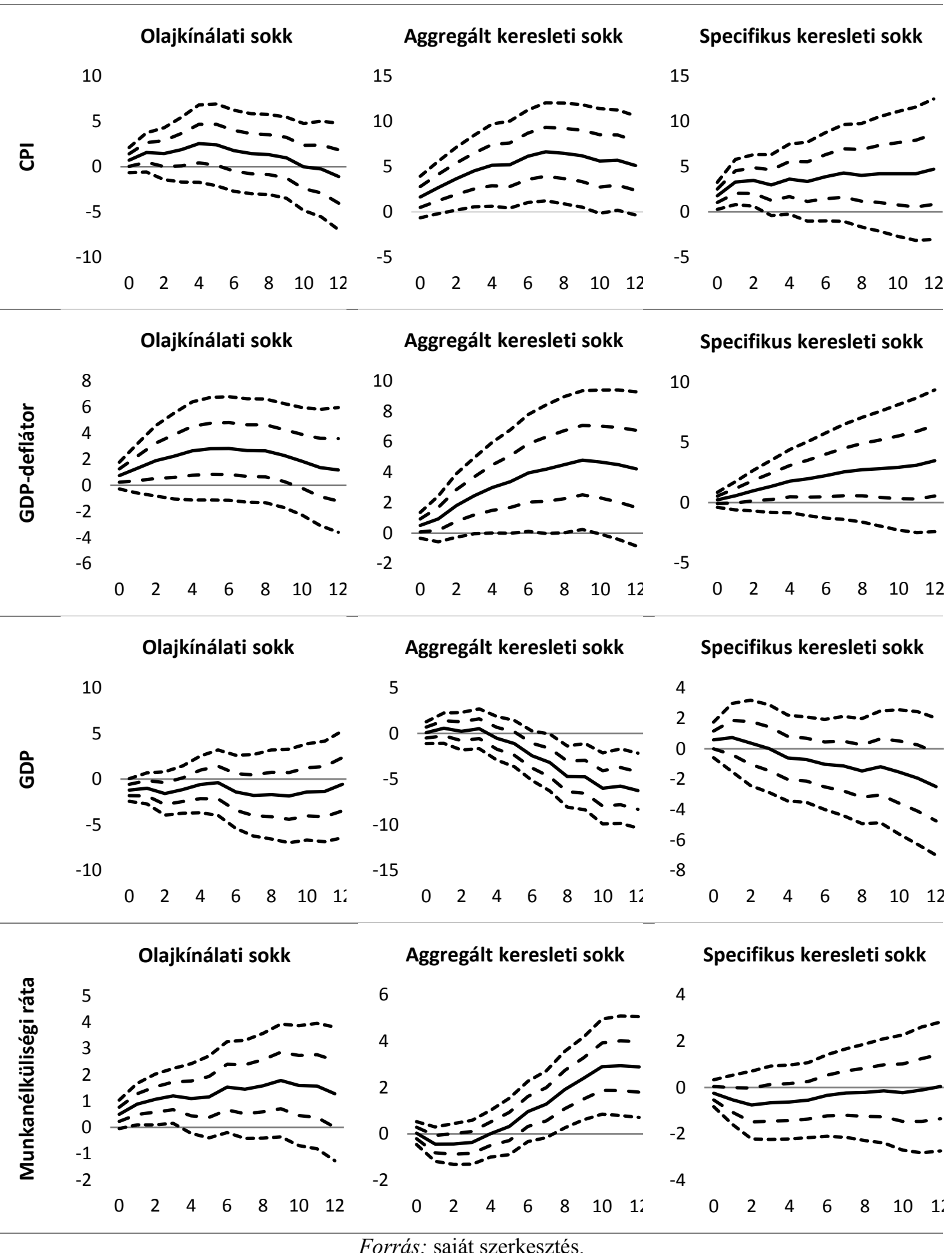

Megjegyzés: Az ábrák értelmezése a szövegben került bemutatásra. 


\section{II.2.4. A makrogazdasági hatások időbeli változása}

A Kalman szürős modellből nyert eredményeket a 9-11. ábrák tartalmazzák. Minden esetben a címben megjelölt, egységnyi nagyságú sokkhoz tartozó kumulált impulzus válasz függvények kerülnek megjelenítésre, azaz a makrogazdasági változó szintjében bekövetkezett változás, az alappályától (a sokk nélküli esettől) való százalékos (munkanélküliségi ráta esetében százalékpontos) eltérés látható. Továbbra is igaz, hogy a kínálati sokknál egy nem várt termeléskiesés hatása szerepel. Minden ábra azonos struktúrát követ. Az első oszlopban az egységnyi sokk sor szerinti makrováltozó szintjére vonatkozó hatása szerepel 3 évre elöre, negyedéves bontásban, öt különböző időpontban, azaz attól függően, hogy a nem várt változás mikor következett be. A vizsgált negyedévek a következők: 1978Q1, 1987Q4, 1996Q4, 2005Q4, 2014Q4. A második oszlopban szintén a kumulált IVF-ek szerepelnek, de már egy másik nézőpontból. Innen azt lehet leolvasni, hogy egységnyi sokknak milyen hatása volt a sor szerinti változó szintjére 0,1 , 2 és 3 évvel a bekövetkezése után, attól függően, hogy ez a sokk melyik negyedévben (vízszintes tengely) következett be. A becslés során az egy és két standard hibányi konfidencia intervallumok is kiszámításra kerültek, melyek a hatás szignifikanciájáról adnak információt. Az ábrák harmadik oszlopában található hőtérképek e szignifikancia tesztek eredményeit hivatottak grafikus formába süríteni. A vízszintes tengelyen a sokk bekövetkezésének időpontja szerepel, míg a függőleges tengely rögzített, mindig 0-12 negyedévet jelöl. A hőtérkép gyakorlatilag egy mátrix, aminek (i; j) eleme azt mutatja, hogy a j. negyedévben bekövetkező sokk hatása szignifikáns-e i negyedévvel a bekövetkezés után (az ábrán a sorok sorrendje fel van cserélve, azaz a legfelső sorban nem az azonnali, hanem a 12 negyedévvel későbbi hatás szerepel, míg az azonnali hatáshoz az alsó sor tartozik). Ha a hatás a két standard hibányi konfidencia intervallum mellett is szignifikáns, akkor a mező fekete, ha csak egy standard hiba mellett tekinthető statisztikailag nullától különbözőnek, akkor szürke, minden egyéb esetben, tehát amikor a hatás inszignifikáns, fehér.

\section{Kínálati sokk}

Kínálati sokkok tekintetében az eredmények vegyesek (9. ábra). Az árindexeknél szinte sosem találunk szignifikáns hatást. Ez alól CPI-nél a pénzügyi, gazdasági válság időszaka jelent kivételt, ahol majdnem a teljes 3 éves horizonton statisztikailag kimutatható az összefüggés, igaz, ahogy az első sor második oszlopában található grafikonról 
leolvasható, a modell szerint ekkor kifejezetten negatív hatása volt egy nem várt kiesésnek. Mivel a későbbiekben ez a szignifikancia teljesen eltünt, nem zárható ki, hogy csak átmeneti jelenségről volt szó, amit a válság okozta zaj számlájára írhatunk, és amit az alkalmazott módszertan nem tudott megfelelően kezelni. Az implicit árindexnél ez a kiugrás már nem jelenik meg, bár itt nagyjából 2000-től kezdve enyhén szignifikáns eredményeket kapunk, legalábbis a sokkot követő 1-2 negyedév távlatában, ami némi inflációs nyomás kialakulására, majd gyors eliminálódására utal.

A GDP szintjére egy kínálati sokknak maximum fél évig volt szignifikáns befolyása, ennél hosszabb időtávon legfeljebb 1980 körül lehetett némi hatása, ami azonban egyszeri kiugrásnak tekinthető. A 0-2 negyedéves időtávon nincs egyértelmü trend, a szignifikancia szintje hol erősödött, hol gyengült, a pontbecslés pedig a negatív tartományokban mozgott.

A nem várt kisések hatása tehát sem a vizsgált árindexek, sem a GDP esetén nem mutat egyértelmű időbeli változást, vagy ha igen, akkor az nem tünik trendszerü elmozdulásnak. Ezzel szemben az amerikai munkanélküliségi ráta egyre erősebben reagál a kínálati sokkokra, ami mind a pontbecslésben, mind annak szignifikanciájában megjelenik. Blanchard és Gali [2007] szerint a rugalmasabb munkaerö-piac segít tompítani az olajár növekedésének negatív hatásait, amiből az következne, hogy a foglalkoztatás - legalábbis hosszú távon - kevésbé érzi meg a külső sokkokat, itt azonban nem ezt látjuk. Ez pedig rá is mutat a módszertan egyik hiányosságára. Egy kínálati sokk nem tekinthető homogénnek, a forrás lehet az OPEC-en belül és kívül, vagy ami jelen esetben még fontosabb, az USA-n belül és kívül. Nyilvánvaló, hogy a palaolaj termelés felfutása nem ugyanazt jelenti az amerikai munkaerö-piacnak, mint a szaúdiak termelésbővítése, pedig a metodológia szerint mindkettő ugyanolyan kínálati sokknak számít. Azonban míg utóbbi legfeljebb az olcsóbb olajon és a monarchia amerikai termékek iránti megnövekedett keresletén keresztül fejthet ki hatást, addig elöbbi közvetlenül érinti az USA olajiparának és beszállítóinak munkavállalóit, az adóbevételeket, beruházásokat, jövedelmeket stb. Így akár az is elöfordulhat, hogy egy nem várt kiesés munkanélküliségre való hatásának előjele attól függ, hol következik be a kínálati sokk. Ha az USA-ban, az rontja az ottani olajipar és a beszállító ágazatok pozícióit, míg ha külföldön, akkor az amerikai kitermelők még profitálhatnak is a nyersanyag drágulásából. Továbbfejtve Kilian [2009] „nem minden olajársokk egyforma” megállapítását, azt 
mondhatjuk, hogy nem minden kínálati/keresleti sokk egyforma, és bizonyos esetekben szükség lehet az itt használt felbontásnál is mélyebbre ásni (lásd Bodenstein et al. [2012]).

\section{Aggregált keresleti sokk}

A világpiaci reál aktivitás váratlan élénkülése az 1970-es és 1980-as években a későbbieknél jóval erősebb, gyakran enyhén szignifikáns hatást fejtett ki a CPI szintjére, ráadásul ez a hatás sokszor tartós volt, a sokk után 3 évvel is kimutatható maradt (10. ábra). Ez az inflációs nyomás azonban a '90-es évek elején gyakorlatilag teljesen megszünt, és bár a válság során látszólag újra megjelent, a korábbiakhoz hasonlóan itt is csak átmeneti jelenségnek bizonyult, jó eséllyel nem valós összefüggésről, csupán modellezési prolémáról van szó. Ezzel szemben az implicit árindexnél ezúttal sem tapasztalni ilyen jellegű devianciát, és a becslési eredmények arra engednek következtetni, hogy bár a GDP-deflátor szintjében szignifikáns emelkedést okoz egy aggregált keresleti sokk, az eltérés volumene az évtizedek során trendszerűen csökkent, az utolsó években már csak a bekövetkezés utáni 2. negyedévtöl kezdve van némi szignifikancia (amennyiben az egy standard hibányi konfidencia intervallummal dolgozunk). A reál olajár 2000-es években tapasztalt emelkedése során tehát nemcsak azért sikerült elkerülni a pénzromlás ütemének gyorsulását, mert az áremelkedés mögött az aggregált keresleti sokkok felfutása, az ázsiai növekedés beindulása állt, hanem azért is, mert annak inflációs hatása az évtizedek folyamán sokat gyengült.

Hasonló megállapításra jutunk a reálgazdasági hatásokat illetően is. Bár a GDP esetében nem trendszerü gyengülés, inkább folyamatos hullámzás jellemzi az idősort, a pontbecslések szerint épp a 2000-es években meglehetősen enyhe, és a válság rövid időszakát leszámítva inszignifikáns volt az alappályától való eltérés. Megjegyzendö, hogy az eredmények alapján ezt megelőzően sem igazán volt szignifikáns a hatás. Az utóbbi években ugyanakkor ismét erősödni tudtak az aggregált keresleti sokkok negatív következményei, de csak újabb adatok beérkezése után lehet majd eldönteni, hogy ez valamiféle trend kezdete vagy a korábbi hullámzás folytatódása.

A munkanélküliségi rátánál már sokkal egyértelmübb, hogy a globális kereslet nem várt emelkedése egyre kevésbé érinti a változó pályáját. A kumulált IVF-ek szerint a sokk bekövetkezése utáni 0,5-3 évben a munkanélküliségi ráta annál kevésbé emelkedett, minél később történt a váratlan esemény. A sokk utáni első fél/háromnegyed évben 
ráadásul az egy standard hibányi konfidencia intervallum szerint még szignifikáns csökkenés is történik. Ennek oka, hogy bár a nyersanyagok iránti kereslet élénkülése emeli az amerikai importkiadásokat, azonban a világgazdasági élénkülés kezdetben ellensúlyozza ennek negatív hatásait, ahogy az már az időben változatlan paraméterü modellnél is megállapítható volt.

Így összességében elmondható, hogy az aggregált keresleti sokkok árindex növelő hatása jelentősen gyengült az elmúlt évtizedek folyamán, a GDP esetén a befolyás mértéke hol gyengébb, hol erősebb volt, de épp a 2000-2010-es időszakban inszignifikancia jellemezte, míg a munkaerő-piac ellenálló képessége az egész mintaidőszak alatt javuló tendenciát mutatott. Ez arra enged következtetni, hogy a 2000-es években a stagfláció elmaradása részben a sokkok összetételének, részben az olajár emelkedését okozó sokktípus gyengülő makrogazdasági hatásainak volt köszönhető.

\section{Specifikus keresleti sokk}

A biztonsági vásárlásokkal összefüggő specifikus keresleti sokkok makrogazdasági hatásainál is azt találjuk, hogy az évtizedek folyamán komoly változáson mentek át. Ez azért különösen érdekes, mert az olajár válság utáni visszaemelkedésében, valamint a 2014 második felében indult áresésben is e sokkok jelentették a domináns elemet (7. ábra). Így vizsgálatukkal képet nyerhetünk arról, milyen szerepet játszott a magas olajár a válságból való kilábalás során, illetve milyen makrogazdasági következményekkel járhat a legutóbbi árzuhanás. Az eredményeket a 11. ábra foglalja össze.

Az amerikai fogyasztóiár-index az évtizedek folyamán egyre ellenállóbb lett a specifikus keresleti sokkokkal és az általuk kiváltott átmeneti olajár emelkedéssel szemben. A '80as években volt a legnagyobb és leginkább szignifikáns az alappályától való eltérés, majd folyamatos csökkenés után a 2000-es évek közepére szinte teljesen eliminálódott az inflációs nyomás, ráadásul az enyhülés a sokk bekövetkezése utáni 3 év egészében megfigyelhető, a kumulált IVF minden horizonton a vízszintes tengelyhez közelített. Ezt követően azonban hirtelen visszarendeződés történt, és bár a pénzügyi, gazdasági válság lecsendesedése után újra némi enyhülést figyelhetünk meg, napjainkban ismét a '80-as évekhez hasonló erősségű és szignifikanciájú inflációs nyomás jellemző. Míg a kínálati és az aggregált keresleti sokkok esetén lehetett a válság okozta zajjal magyarázni a történteket, hasonló okfejtés itt már aligha állná meg a helyét, hiszen nem tapasztalunk 
kellő mértékü korrekciót. Egy lehetséges magyarázat szerint az olajspecifikus keresleti sokkok az olajáron keresztül az amerikai olajszektorra pozitív hatást fejtenek ki, a megnövekedett jövedelem pedig élénkíti az USA aggregált keresletét, ezáltal emeli az árszínvonalat. Kérdéses persze, hogy az egyéb ágazatokat érintő többletteher nem ellensúlyozza-e ezt a hatást. Természetesen továbbra is lehetséges, hogy csupán a rossz modellspecifikáció okozza ezt a dinamikát, és részletesebb bontás, valamint egyéb magyarázó változók (pl. a Fed monetáris politikájának) figyelembe vételére lenne szükség. Mindenesetre az eredmények azt sugallják, hogy a 2014-ben esésnek indult olajár legalább rövid távon (az első fél évben) szignifikáns dezinflációs hatással bír.

Egységnyi specifikus sokk a bekövetkezés után 2-4 negyedévvel szignifikáns növekedést eredményezett az implicit árindex szintjében, függetlenül attól, hogy az elmúlt 40 év során mikor következett be. Ráadásul a modellbecslés szerint a hatás volumene is változatlan volt az évtizedek alatt. 1 éven túl azonban jól látható, hogy az alappályától vett differencia jelentősen szűkült, a minta végén 2 éven túl már semmiféle szignifikancia nem mutatható ki, és 1-2 éves távlatban is csupán az egy standard hibányi konfidencia intervallum mellett tekinthetjük statisztikailag nullától különbözőnek a kumulált hatást. Így a CPI-hez hasonlóan itt is azt mondhatjuk, hogy a mintaidőszak végére jellemző negatív specifikus sokkok ugyan némileg csökkentik a GDP-deflátor nagyságát, e hatás azonban nem lesz tartós, nagyjából 1-2 év elteltével teljesen eliminálódik.

A GDP esetén meglehetősen vegyes eredmények születtek, ugyanakkor a szignifikancia tesztek alapján legfeljebb a minta második felében, a sokk bekövetkezése után 0-1 negyedévvel van szignifkáns hatása egy specifikus keresleti sokknak (ez azonban csak az egy standard hibányi konfidencia intervallum használata mellett igaz). Meglepő módon a pontbecslés ekkor enyhén pozitív elmozdulást jelez, azaz a biztonsági vásárlások felfutása inkább élénkíti, nem pedig csökkenti a GDP-t. A kumulált IVF-ek 0 és 1 negyedév esetén pedig trendszerü emelkedést mutatnak, ami a hatás erősödését jelenti (a 11. ábrán csak az azonnali hatás időbeli változása szerepel, de az 1 negyedéves érték is hasonló dinamikát mutat). Ezt a trendet a jövőben tovább erősítheti az amerikai gazdaság strukturális változása, az olajszektor növekvő fontossága. Az eredmények egyben arra is rámutatnak, hogy az olajár legutóbbi csökkenéséből nem feltétlenül tud majd profitálni az amerikai gazdaság, sőt, átmeneti lassulás is következhet. 
A munkanélküliségi rátánál ezúttal is a sokkhatás egyértelmü csökkenését tapasztaljuk. A biztonsági vásárlások okozta olajár emelkedés egyre kevésbé járt együtt a munkanélküliség növekedésével, és a mintaidőszak végére $0-2$ negyedéves távlatban enyhén szignifikáns és negatív hatást fejtett ki a mutató értékére, ezzel ismét az amerikai olajszektor fontosságára hívva fel a figyelmet.

Összességében elmondható, hogy a specifikus keresleti sokkok hatása időben jelentős változáson ment keresztül, és az eredmények azt sugallják, hogy a 2008-as válság utáni kilábalás alatt nem hátráltatták, inkább segítették az amerikai gazdaságot a növekedés gyorsításán és a munkanélküliség mérséklésén keresztül. A 2014-ben indult masszív áresés azonban kedvezőtlenül érinthette az USA reálgazdaságát, bár a hatás csak rövid ideig, legfeljebb 1-2 negyedéven át tekinthető szignifikánsnak. 
9. ábra: Egységnyi kínálati sokk hatása az Egyesült Államok makrogazdasági mutatóira (időben változó paraméterű modell eredményei)
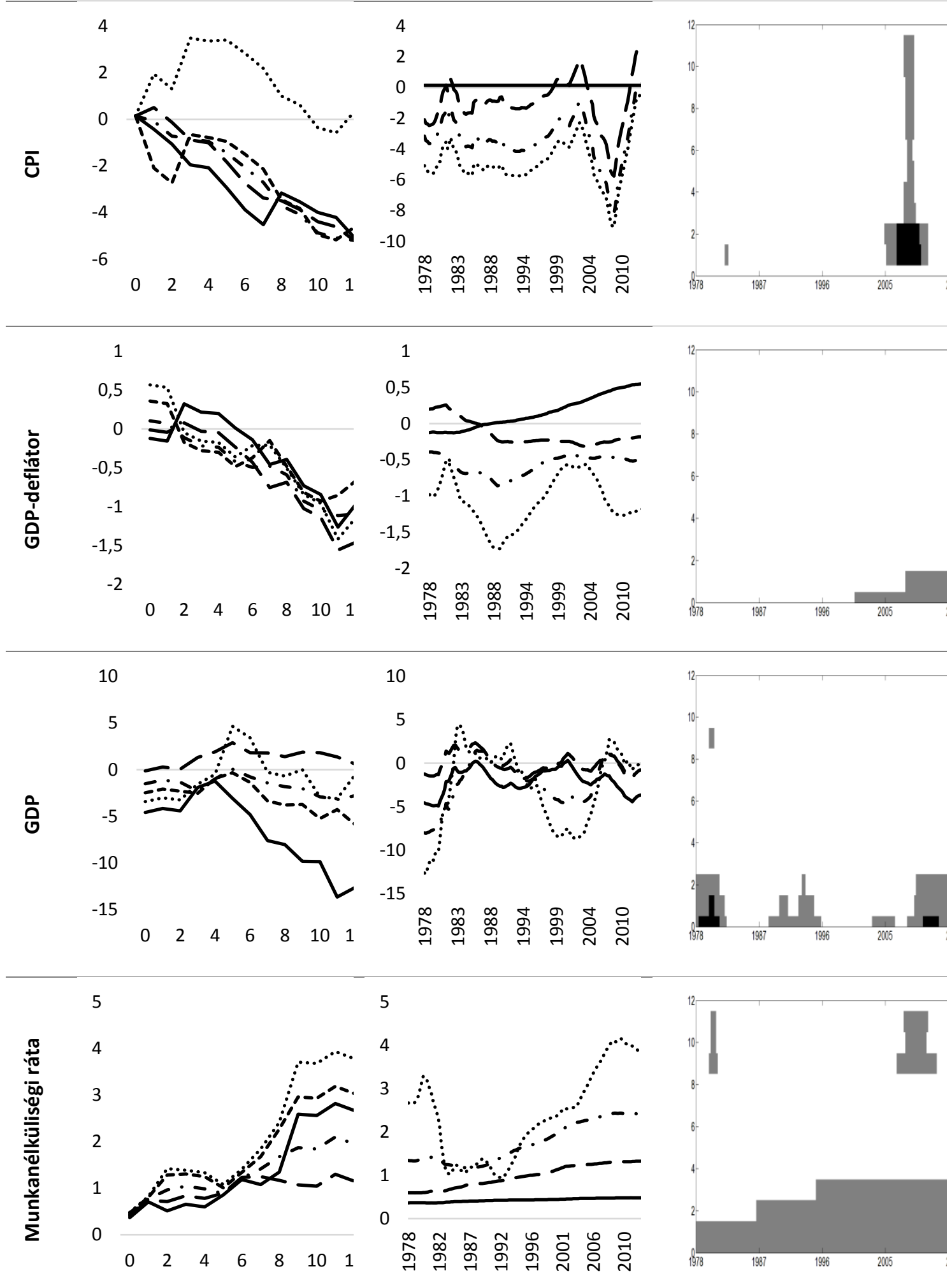

Forrás: Az ábrák értelmezése a szövegben került bemutatásra. Az első oszlopban található jelölések: — 1978Q1, - - 1987Q4, - - 1996Q4, - - 2005Q4, … 2014Q4. A második oszlopban található jelölések: — 0 negyedév, --4 negyedév, $-\cdot-8$ negyedév, $\cdots \cdot 12$ negyedév. A 10-11. ábrák értelmezése hasonlóan történik. 
10. ábra: Egységnyi aggregált keresleti sokk hatása az Egyesült Államok makrogazdasági mutatóira (időben változó paraméterű modell eredményei)
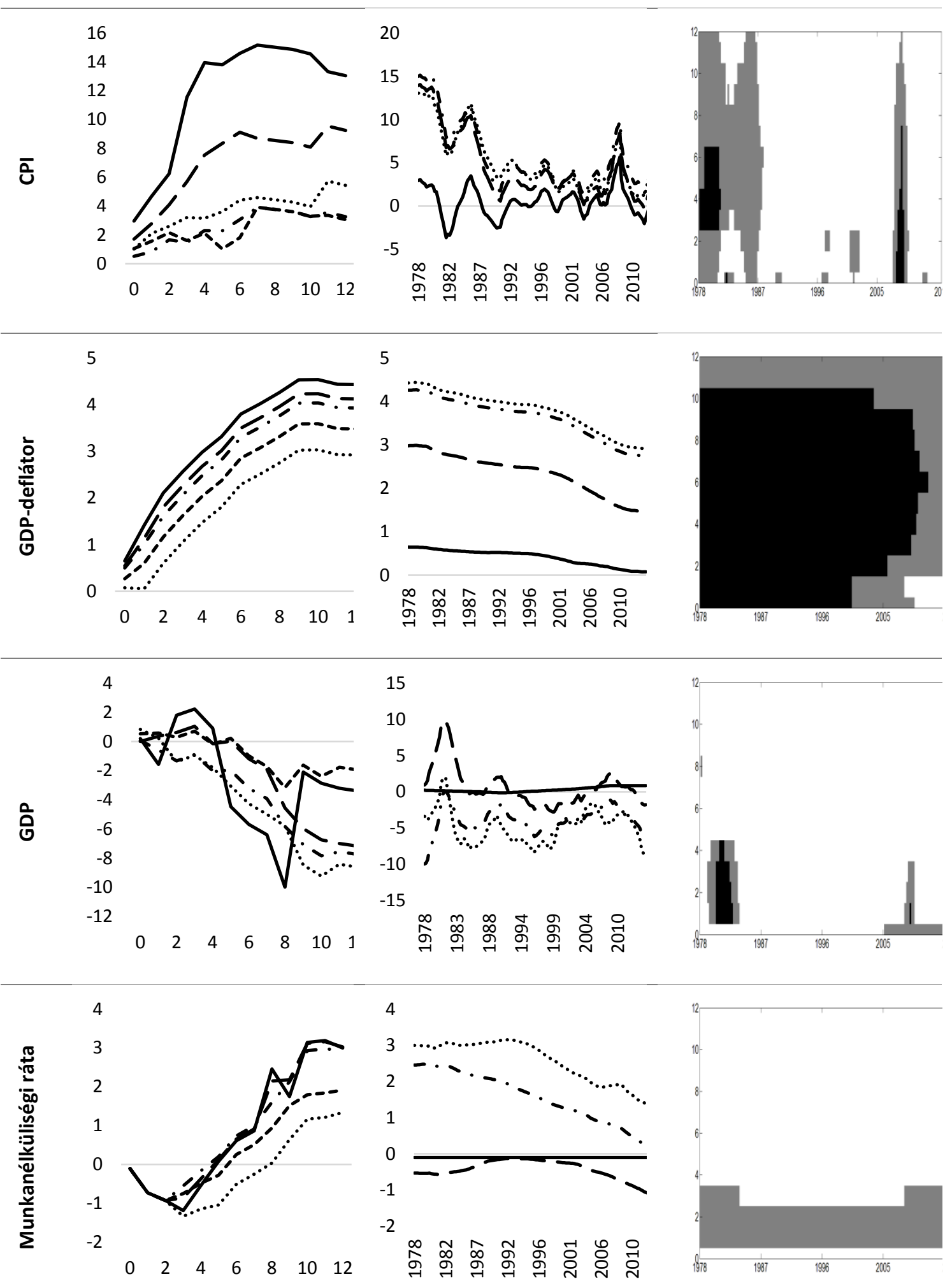

Forrás: lásd a 9. ábrát. 
11. ábra: Egységnyi specifikus keresleti sokk hatása az Egyesült Államok makrogazdasági mutatóira (időben változó paraméterủ modell eredményei)
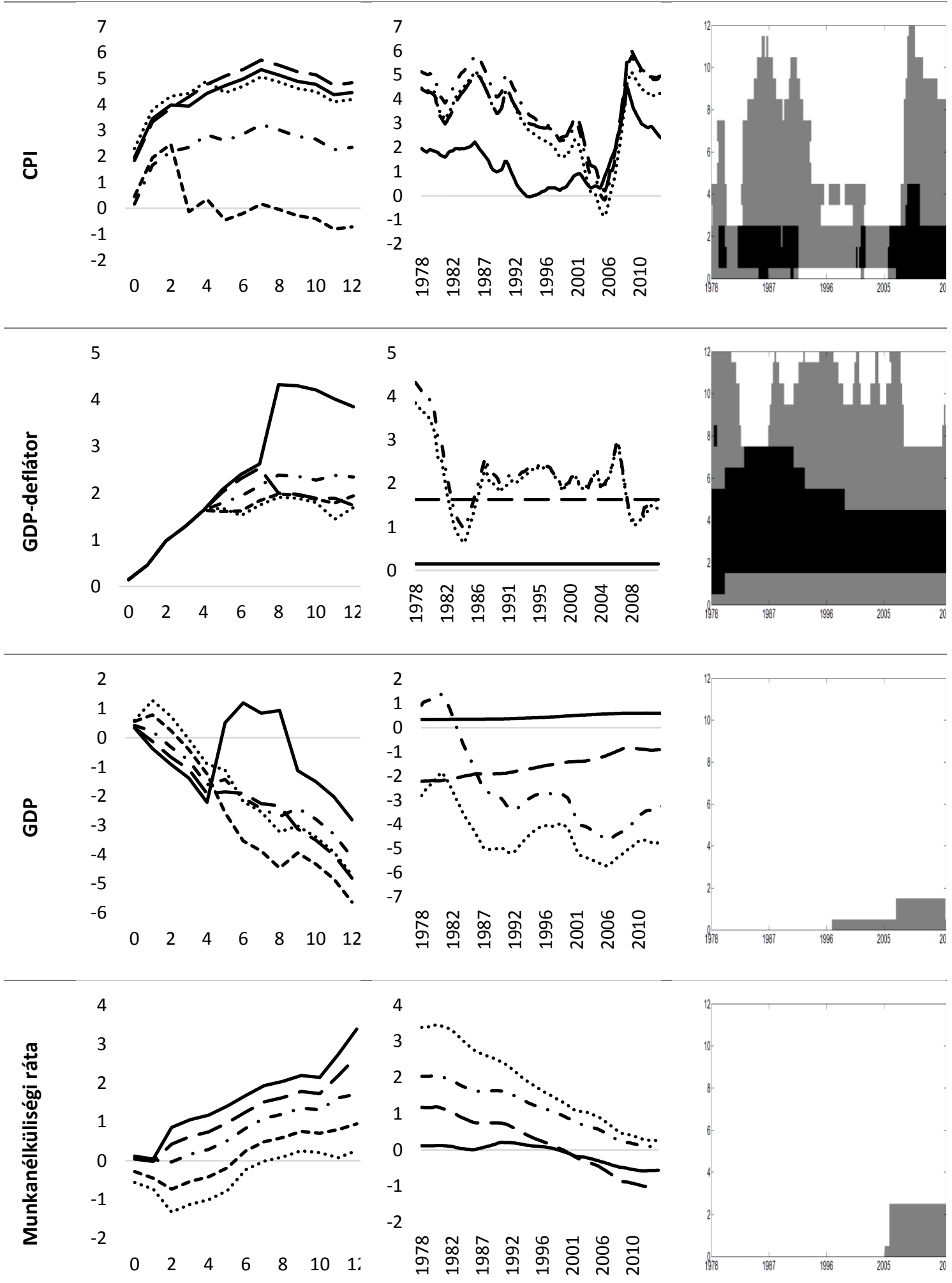

Forrás: lásd a 9. ábrát. 


\section{II.2.5. Robusztusság vizsgálat}

A bemutatott eredmények robusztusságának tesztelésére néhány alternatív eljárással értékelem ki, illetve becsülöm újra a modellek outputjait. A robusztussági vizsgálatokat egyetlen eljárás kivételével nemcsak az eddig vizsgált négy változóra, hanem az amerikai termelői árindexre (PPI), és a szintén az Egyesült Államokra vonatkozó személyes fogyasztási kiadások indexére (PCE) is elvégzem ${ }^{27}$. A korábban bemutatott ábrák PCEre és PPI-re vonatkozó megfelelői a függelékben találhatóak. A főbb megállapítások:

- A Kilian [2009] féle megközelítést alkalmazva kiderül, a korábbiakhoz hasonlóan igaz (lásd a 36. ábrát), hogy a kínálati sokkok hatása a teljes időszak (1975Q12014Q4) átlagában inszignifikáns, míg az aggregált keresleti sokkok időben erősödő, a specifikus keresleti sokkok pedig időben gyengülő inflációs hatással járnak, azaz míg előbbinél a sokk bekövetkezése után több negyedéven keresztül nő az alappályától való eltérés, addig utóbbinál az első negyedévekben éri el a maximumát. A kumulált IVF-ek alapján a PPI esetében erősebb a szignifikancia.

- A Kalman-szürős modellböl származó eredmények (37-38. ábra) szerint mind a PPI-nél, mind a PCE-nél jelentős zajt visz a becslésekbe a 2007-2008-as pénzügyi válság, ekkor ugyanis megnő a sokkok hatásának szignifikanciája és az IVF-ek kilengése. Ugyanakkor összességében azt tapasztaljuk, hogy a kínálati sokkok ezt a rövid periódust leszámítva nem bírtak statisztikailag kimutatható inflációs hatással, míg a különböző keresleti sokkok befolyása stagnált vagy enyhült az évtizedek folyamán (ismét eltekintve a 2005-2010 között kimutatott visszaerősödéstől).

\section{Az eredmények alternativ kiértékelése}

A Kalman-szürős eljárással kapott IVF-ekből nyert konklúziók akkor sem változnak, ha a korábban bemutatott eljárás helyett alternatív megközelítésekkel dolgozunk. Itt két esetet mutatok be.

Az elsőben a kumulált IVF-eknek a sokk bekövetkezése után 0, 1, 2 stb. negyedévvel későbbi értékeit minden egyes $(0,1, \ldots, 12)$ negyedévre kiátlagolom a minta első

\footnotetext{
${ }^{27}$ Mindkét változó forrása a FRED adatbázis. A PPI havi idősora szezonálisan igazítatlan formában állt rendelkezésre, ezért X12 eljárással, multiplikatív szezonalitás feltevése mellett szürtem ki a szezontényezőből fakadó elmozdulásokat. A változókon végrehajtott egyéb transzformációkat a CPI mintájára végeztem.
} 
(1975Q1-1994Q4) és második (1995Q1-2014Q4) felére, és ezek különbségét vizsgálom. Mindez formálisan:

$$
\Delta_{i}=\left(\sum_{t=1995 Q 1}^{2014 Q 4} \sum_{j=0}^{i} \widehat{\theta_{J t}}-\sum_{t=1975 Q 1}^{1994 Q 4} \sum_{j=0}^{i} \widehat{\theta_{J t}}\right) / 80
$$

Ahol i=0,1, ., 12. Az eredményeket a 19. táblázat tartalmazza (lásd a Függeléket). Ebből kitünik, hogy:

- A CPI, a PCE, a GDP deflátor és a munkanélküliségi ráta esetén a keresleti sokkok hatásai főleg negatív irányba változtak, összhangban az idősoros vizsgálat megállapításaival (lásd 9-11. ábra).

- A specifikus keresleti sokkok GDP-re vonatkozó hatásánál az elmozdulás iránya a bekövetkezést követő 0-3. negyedévekben pozitív, ami a gazdaság jobb ellenálló képességére utal (ennél hosszabb időtávon nem volt szignifikáns az alappályától vett eltérés).

- Ezzel szemben az aggregált keresleti sokkoknál inkább az IVF-ek negatív irányú elmozdulását (az esetleges recessziós hatás mélyülését) mutatják az eredmények. Ennek oka, hogy a 10. ábrán látottak szerint, bár a hatás időben folyamatosan változott, az elmozdulás inkább egyfajta hullámzó mozgást mutatott, nem pedig trendszerü csökkenést/növekedést. Az aggregálás során ez az információ elvész, és csak a változások átlaga marad, ezért van látszólagos ellentmondás a korábbi eredményekkel.

- PPI-nél az aggregált kereslet hatása inkább pozitív (inflációs nyomás erősödése), míg a specifikus keresleté negatív irányba mozdult. Ugyanakkor a változás előjelét jelentős részben a 2007-2008-as válság során megfigyelt kiugrások okozták, amelyek torzítják az eredményeket.

- A kínálati sokkok hatása a PCE-t leszámítva minden vizsgált változónál inkább pozitív elmozdulást mutat a két időszak között. Ez hol az abszolút hatás erősödését, hol a gyengülését jelzi. A korábbi eredmények alapján azonban a munkanélküliségi ráta volt az egyetlen olyan mutató, amely a mintaidőszak egésze során szignifikáns elmozdulást produkált a termelési volumen nem várt változásainak következtében, így a vizsgálat során érdemes csak ezt az esetet 
figyelembe venni. Az Egyesült Államok munkaerö-piacának megnövekedett érzékenysége pedig megfelel a korábbi konklúzióknak.

A második megközelítésben lineáris trenddel modellezzem az egyes $(0,1, \ldots, 12)$ negyedévekhez tartozó kumulált IVF-ek változásának irányát a teljes (1975Q1-2014Q4es) mintán. Azaz veszem az azonnali (0. negyedéves) hatást és az ehhez tartozó $\theta_{0 t}$ értékeket minden $t$ negyedévre ( $\mathrm{t}=1975 \mathrm{Q} 1, \ldots, 2014 \mathrm{Q} 4)$, majd erre az idősorra illesztek lineáris trendet OLS eljárással:

$$
\theta_{0 t}=\theta_{0}+T_{0} \cdot t+\vartheta_{0 t}
$$

Ahol $T_{0}$ az azonnali hatás koefficienséhez tartozó trendparaméter értéke, $\vartheta_{0 t}$ pedig a hibatag. Ugyanezt megismétlem a több negyedévvel későbbi hatásokra is, de ott már a $\sum_{j=0}^{i} \theta_{j t}$ idősorokra (ahol i=1, 2, .., 12 jelöli a sokk bekövetkezése óta eltelt negyedévek számát). Az eredményeket a 20. táblázat (Függelék) tartalmazza. Az eredmények nagyon hasonlóak az első esetben látottakhoz, így a levont következtetések sem változnak. Mindent egybevetve, az alternatív kiértékelési technikák megerősítik a korábbi megállapításokat, ugyanakkor arra is rámutatnak, hogy az aggregálás érzékeny a kiugró értékek jelenlétére, illetve kevéssé használhatóak azokban az esetekben, amikor a makrogazdasági hatások idősorában csökkenő és növekvő trendek váltogatják egymást (lásd a GDP és az aggregált keresleti sokkok példáját).

\section{Kilian [2009] modelljének becslése a minta első és második felére}

A Kalman-szürő használata helyett a Kilian [2009] által alkalmazott becslést a minta első (1973Q1-1994Q4) és második felére (1993Q1-2014Q4) külön is elvégzem. Jelen esetben az okozza a részminták közti átfedést, hogy a 24 hónapos késleltetés miatt a felhasznált időszak első 2 éve kiesik, így az előbb meghatározott intervallumok végül az 1975Q11994Q4, illetve az 1995Q1-2014Q4 periódusokra rövidülnek. Az eredmények ezúttal is a Függelékbe kerültek (39-44. ábrák). A föbb megállapítások többnyire egybecsengnek a korábbiakkal:

- A keresleti sokkok inflációs hatása minden esetben gyengült, vagy akár teljesen el is tünt. 
- A kínálati sokkok az első részmintán még dezinflációs hatással bírtak, míg a második időszakban eltünt a szignifikancia (a pontbecslés többnyire nullához közeli, pozitív elmozdulást jelez).

- A sokkok munkanélküliségi rátára vonatkozó átlagos hatása jelentősen változott a két időszak között. A kínálati sokké növekedett, míg a keresleti sokkoké csökkent, sőt, átfordult negatívba.

- A GDP sokkokra adott reakciója mindhárom esetben megfordult. A pontbecslés alapján a keresleti sokkok recessziós hatása a második részmintán szinte teljesen eltünt, és a pozitív tartományokba emelkedett, bár az alappályától való átlagos eltérés végig inszignifikáns. Meglepő azonban, hogy míg a kínálati sokkok átlagos hatása az első részmintán pozitív (bár inszignifikáns) volt, addig a második időszakra ez a negatív tartományokba esett, néhol szignifikáns recessziós hatást mutatva.

Az egyetlen kérdőjel tehát a GDP és a kínálati sokkok megváltozott kapcsolata, amit a Kalman-szürős eljárás eredményeiből nem lehetett kiolvasni. Az olajszektor térnyerése erre is potenciális magyarázattal szolgálhat, ugyanakkor figyelembe véve, hogy itt az 1995Q1-2014Q4-es időszakra jellemző átlagos hatásról van szó, kevéssé tűnik valószínünek, hogy az utolsó éveket érintő palaolaj termelés felfutása egymaga okozta volna az IVF ilyen mértékủ változását. Többek között a válság generálta zaj, a valójában eltérő hatású kínálati sokkok aggregálása és egyéb modellezési problémák lehetnek azok a további tényezők, amelyek együttesen vezettek ehhez az eredményhez. Mindenesetre ez gyengíti a korábbi konklúziókat, igaz, a kínálati sokkok eleve nem játszottak meghatározó szerepet a reál olajár alakulásában, így a makrogazdasági változókat is csupán marginálisan befolyásolhatták. 
A következő robusztussági vizsgálat során a Kalman-szürő helyett az időben változó paraméterü egyenleteket úgy állítom elő, hogy feltételezem, a koefficiensek lineáris trendet követnek, mégpedig minden negyedévhez tartozó parciális hatás esetén eltérő meredekséggel:

$$
\Delta y_{t}=\delta+\mu \cdot t r+\sum_{i=0}^{12}\left(\theta_{i}+\tau_{i} \cdot t r\right) \cdot \hat{\xi}_{j t-i}+u_{t}
$$

Ahol $t r$ a trendváltozó, $\mu$ és $\tau_{i}$ pedig a különböző trendparaméterek értékei. Az egyenletet minden makrogazdasági változó/sokk pár esetén megbecsülöm, mégpedig OLS eljárással, Newey-West féle heteroszkedaszticitás és autokorreláció robusztus standard hibák használata mellett ${ }^{28}$. Az eredmények ezúttal is a Függelékbe (21-22. táblázat) kerültek $^{29}$. A kumulált hatásokra vonatkozó következtetések az alábbiak:

- A becslés alapján egy 1975Q1-ben bekövetkező keresleti (aggregált vagy specifikus) sokknak kimutatható árindex növelő hatása volt, ugyanakkor a trendparaméterek a PPI-től eltekintve föleg negatív, gyakran szignifikáns változást jeleznek, ami a hatás enyhülésére utal.

- A kínálati sokkok kezdetben inflációs hatással bírtak rövid (0,5-1,5 éves) távon, bár a koefficiensek csak az 1 standard hibányi konfidencia intervallum mellett tekinthetők szignifikánsnak. Később ez a hatás gyengülni kezdett (negatív, és 1 standard hibányi konfidencia intervallum használata mellett szignifikáns trendparaméterek).

- A munkanélküliségi ráta kezdetben növekedett egy specifikus keresleti sokk hatására, azonban az évtizedek folyamán az alappályától való eltérés elindult a negatív tartomány irányába. Az aggreált keresleti, illetve kínálati sokkoknak e modell szerint nem igazán volt befolyása.

\footnotetext{
${ }^{28}$ Ez a megközelítés továbbra sem kezeli a generált regresszorok problémáját.

${ }^{29}$ Bár az outputokat külön nem közlöm, a fenti formájú egyenleteket a $\mu \equiv 0$ megkötés mellett is megbecsültem. Ez a módosítás nem okozott érdemi változásokat, a levont konklúziók e beállítás mellett is érvényesek maradnak.
} 
- A GDP-nél kapott eredmények arra utalnak, hogy a sokkok kezdetben enyhe rövid távú (legfeljebb 1 éves) recessziós hatással bírtak, azonban a (pozitív és szignifikáns) trendparaméterek alapján ez egyre kevésbé tudott érvényesülni.

\section{A Kalman-szürös modell bővitése}

Az utolsó eljárás csupán annyiban különbözik a dolgozatban bemutatott esettől, hogy a makrogazdasági hatások becslésére felírt időben változó paraméterü egyenletek jobb oldalán a függő változó utolsó négy negyedévnyi értéke is megjelenik. Formálisan:

$$
\begin{gathered}
\Delta y_{t}=\delta_{t}+\sum_{i=0}^{12} \theta_{i t} \hat{\xi}_{j t-i}+\sum_{k=1}^{4} \varphi_{k t} \Delta y_{t-k}+u_{t} \\
\varphi_{k t+1}=\varphi_{k t}+\eta_{k t+1}
\end{gathered}
$$

Ahol $\eta_{k}$ nulla várható értékü gaussi fehér zajokat jelöl $(\mathrm{k}=1, \ldots, 4)$. A 9-11. ábrák alternatív modellspecifikáció melletti megfelelői a Függelékben találhatóak (45-47. ábrák). A vizsgálat főbb eredményei:

- Kinálati sokk

1) A GDP-deflátor kivételével gyakorlatilag minden esetben elmondható, hogy (egy-egy kivételes alkalomtól eltekintve) a kumulált IVF-ek elemei statisztikailag nem különböznek nullától.

2) Az implicit árindexnél azt látjuk, hogy egy kínálati sokk rövid távon az alappályához képest alacsonyabb szintre nyomja a mutató értékét, ám két standard hibányi konfidencia intervallum használata mellett csak az azonnali hatás szignifikáns. Ugyanakkor az utolsó évekre már ez sem igaz (csökken az alappályától vett eltérés).

3) Összességében a dinamika (az IVF-ek alakja) keveset változik az alternatív modellspecifikáció hatására.

- Aggregált keresleti sokk

1) A CPI esetét leszámítva nem változnak az eredeti specifikáció melletti megállapítások. A munkanélküliségi ráta és az implicit árindex időben egyre kevésbé növekszik egy aggregált keresleti sokk hatására, illetve a 
munkanélküliségi ráta értéke rövid távon még szignifikáns süllyedést is mutat. A GDP-hez rendelt kumulált IVF-ekben továbbra sem lehet trendszerü elmozdulást találni, az évtizedek során hol kisebb, hol nagyobb kilengések követték a sokk bekövetkezését, de továbbra is igaz, hogy a 2000-es években (egészen a válság kezdetéig) relatíve alacsony és inszignifikáns volt a hatás.

2) A CPI alappályától vett eltérése az egységnyi nagyságú sokk bekövetkezése utáni 6 negyedévben némileg csökkent az évtizedek során, de a különbség kevésbé látványos, mint az eredeti beállítás mellett. Ennél hosszabb időtávon inkább erősödött a hatás, bár a kumulált IVF értékei ekkor is legfeljebb az egy standard hibányi konfidencia intervallum használata mellett tekinthetők szignifikánsnak.

- Specifikus keresleti sokk

1) A CPI, a GDP és a munkanélküliségi ráta esetén most is a kedvezőtlen hatások enyhülése figyelhető meg, hasonlóan az eredeti modell eredményeihez. Némi különbség, hogy az inflációs nyomás csökkenése ezúttal egyértelmübb, illetve itt már rövid távon sem jelentkezik a specifikus keresleti sokkok munkanélküliségi rátát mérséklő hatása.

2) A GDP-deflátorhoz tartozó kumulált IVF alakja ezúttal is eltér az alapesettől. Bár az új beállítás mellett is arra a következtetésre lehet jutni, hogy az elmúlt 40 évben szükült az alappályától vett eltérés (legalábbis a bekövetkezés utáni első két évben), ám ennek mértéke minimális.

Megállapítható tehát, hogy bár van némi eltérés az alternatív eljárások outputjai között, a fö következtetéseket egyik sem cáfolja, az eredmények robusztusnak tekinthetők.

\section{II.2.6. Konklúziók és továbblépési lehetőségek}

A bemutatott eredmények alapján a következő konklúziókat vonhatjuk le:

1. A kínálati sokkok (az olajtermelésben bekövetkező nem várt változások) kevéssé befolyásolták a reál olajár alakulását, és néhány rövid periódustól eltekintve a vizsgált árindexekre sem gyakoroltak szignifikáns hatást. A GDP-t az 1980-as évek elejéig még képesek voltak marginálisan csökkenteni, de a recessziós hatás később sokat gyengült. A munkanélküliségi ráta esetén épp ellentétes folyamatot tapasztalunk, ami az amerikai olajtermelés bővüléséből fakadhat. 
2. A világpiaci reál aktivitást (a nyersanyagok iránti globális keresletet) érintő aggregált keresleti sokkok a CPI és a GDP-deflátor árindexeket a mintaidőszak elején még szignifikánsan eltérítették az alappályájuktól, de az inflációs nyomás később erőteljesen mérséklődött. A GDP esetén a hatás dinamikusan változott, erősödő és enyhülő szakaszok váltották egymást, de épp a 2000-es évek nagy olajár emelkedésének idején a recessziós nyomás alacsony (és inszignifikáns) maradt. Ebben a periódusban az is segítette a stagflációk elmaradását, hogy a munkanélküliségi ráta az aggregált keresleti sokkokra egyre nagyobb süllyedéssel reagált.

3. A specifikus keresleti sokkok esetén a korábbiaknál kedvezőbb makrogazdasági hatások figyelhetők meg. A CPI és a GDP-deflátor mutatókra gyakorolt abszolút hatás enyhült, míg a munkanélküliségi rátánál épp fordítva, ott az utolsó években egy specifikus sokk (átmenetileg) szignifikánsan csökkentette a változó értékét. Alighanem utóbbival függ össze, hogy a mintaidőszak végén a GDP szintjében némi növekedés mutatható ki a specifikus keresleti sokk bekövetkezése utáni első negyedévekben.

4. Ez alapján kijelenthető, hogy az olajpiaci sokkok makrogazdasági hatásai időben változtak, azaz a 2000-es évek olajár emelkedése nemcsak a folyamatot kiváltó tényezők, az aggregált keresleti sokkok miatt hagyta szinte érintetlenül a főbb makrováltozók alakulását, hanem azért is, mert azok az 1970-es évek óta magával az aggregált keresleti sokkal szemben ellenállóbbak lettek. Ez arra utal, hogy Kilian [2010] ill. Blanchard és Gali [2007] elméletei kiegészítik egymást.

5. A mintaidőszak végén tapasztalt változások ugyan a válság hatására megjelenő zaj következményei is lehetnek, azonban a palaolaj kitermelés felfutása, az USA importőri szerepének gyengülése is részleges magyarázattal szolgálhat az elmozdulásokra.

$\mathrm{Az}$ alfejezetben bemutatott eljárások fejlesztésére, a kutatás továbbvitelére számos lehetőség adódik. A VAR modellben szereplő változók alternatív transzformációinak használata, vagy akár új változók bevonása teheti teljesebbé az elemzést. Ugyanígy hasznos lehet a bemutatott modelleket más makrováltozókra (ipari termelés, maginfláció stb.), illetve országokra kiterjeszteni, valamint a felírt modellek módosítása révén az eredmények robusztusságát tesztelni. Az Egyesült Államok speciális helyzete miatt az eredmények nem általános érvényűek, azonban a használt modellek különösebb 
változtatás nélkül alkalmazhatóak más gazdaságokra is. Érdekes irány lehet az exportőr és importör országok közti különbségek feltárása, valamint annak eldöntése, mely strukturális jellemzők határozzák meg az olajár változásával szembeni „rezisztencia” mértékét. Azt is érdemes vizsgálni, mennyire tekinthető stabilnak a VAR alapján felírt kapcsolat. A dolgozat alapötlete épp az volt, hogy a sokkok makrogazdasági hatásai időben változnak, ez pedig igaz lehet magára az olajpiacra is. Elég csak az amerikai palaolaj termelés felfutására gondolni, ami az elmúlt években alapjaiban változtatta meg a piac szerkezetét, és kulcsszerepe volt az OPEC-en belüli kooperáció gyengülésében. Ezt a kérdést időben változó paraméterü VAR modellekkel lehetne megközelíteni.

A mögöttes folyamatok jobb megértéséhez elméleti modellek építésével juthatunk. Egy ilyen keretben célzottan vizsgálhatóak olyan, itt empirikusan nem tárgyalt kérdések mint a makrogazdasági hatások aszimmetriája, a sokkok finomabb felbontása ${ }^{30}$, a gazdaságpolitikai reakciók szerepe, az erőforrás raktározhatóságából eredő dinamikus döntési probléma, a spekulatív kereslet jelenléte, az olaj és más nyersanyagpiacok közti kölcsönhatás, valamint a nem tökéletes verseny és a piacszerkezet időbeli alakulásának következményei.

\footnotetext{
${ }^{30}$ A sokktípusok körének bővítése azért is célszerü, mert ahogy az eredményekből kiderült, bizonyos esetekben túlzott aggregációt hajtunk végre. Nem mindegy például, hogy a kitermelési volumen emelkedése a Közel-Keleten vagy Észak-Amerikában történik.
} 


\section{II.3.: A 2014-ben kezdődő áresés elemzése}

A válság utáni visszarendeződést követően az árak egészen 2014 nyaráig stabilak maradtak, a WTI jegyzése a 80-110 dollár/hordós sávban mozgott. Ekkor azonban az árak süllyedni kezdtek, 2015 végére sokéves negatív rekordokat döntöttek (12. ábra). A trendforduló kialakulása a korábban tárgyalt elméletekkel jól magyarázható.

12. ábra: WTI nominál ár (2011M1-2015M12)

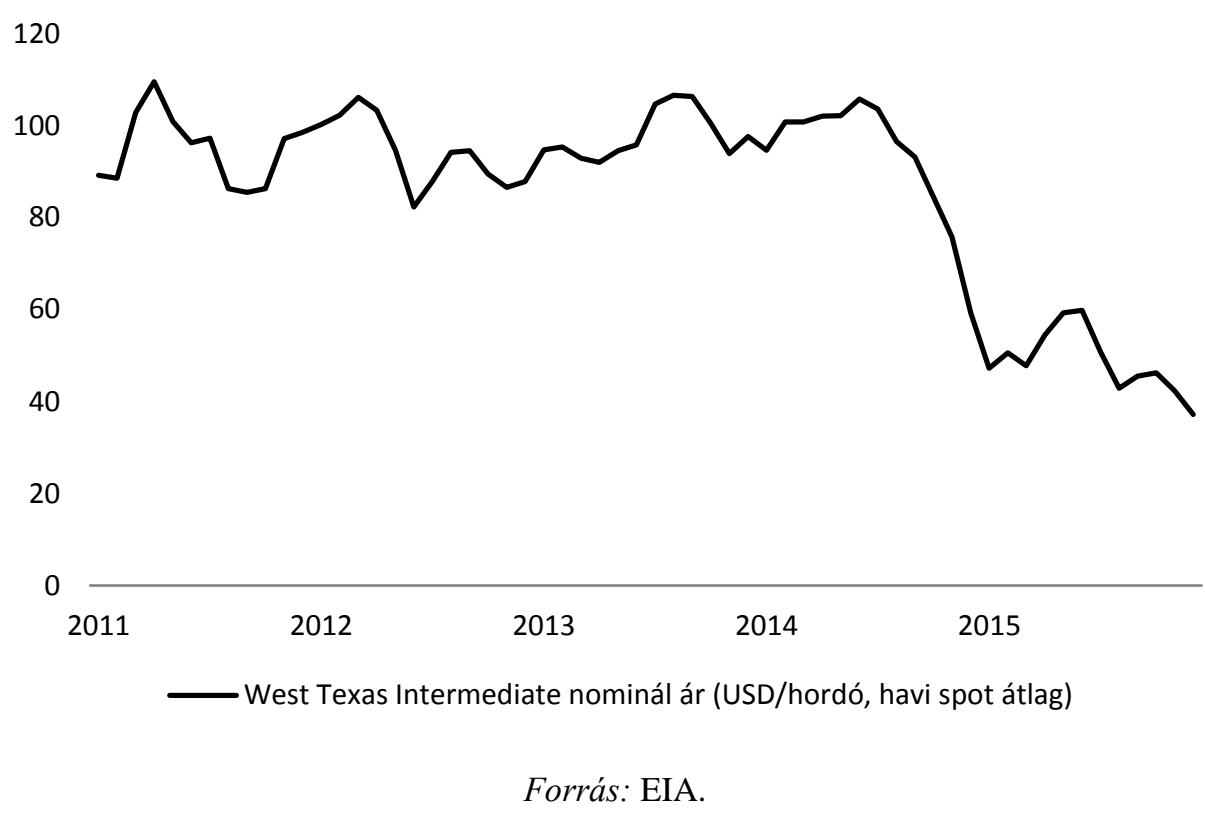

\section{II.3.1. Az áresés okai}

A trend kialakulásának fö mozgatórugói az alábbi tényezők:

- technológiai fejlődés a nem konvencionális készletek (palaolaj, olajhomok...) kiaknázásában

- lassú globális növekedés (a kínai gazdaság szerkezetváltása)

- a dollár erősödése (mennyiségi lazítási program kivezetése, emelkedő kamatlábak)

- az OPEC új stratégiája (kizáró árazás)

A 2000-es évek közepétől Észak-Amerikában gyorsuló ütemben halad a korábban nem, vagy csak rendkívül drágán hozzáférhető palaolaj kitermelése. A fejlesztések révén a felhozatal költsége elég alacsony lett ahhoz, hogy az Egyesült Államokban és Kanadában jelentős mértékben emelkedjen az output. Míg 2010-ben az átlagos napi termelés 5,5 millió hordó környékén alakult az USA-ban, 2014-ben már elérte a 8,65 millió hordót, 
jórészt a palaolajnak köszönhetően. A növekvő trend olyannyira erős, hogy 2015 áprilisában már 9,7 milliónál állt a mutató (13. ábra).

13. ábra: Az Egyesült Államok átlagos napi olajtermelése (1970M1-2015M12)

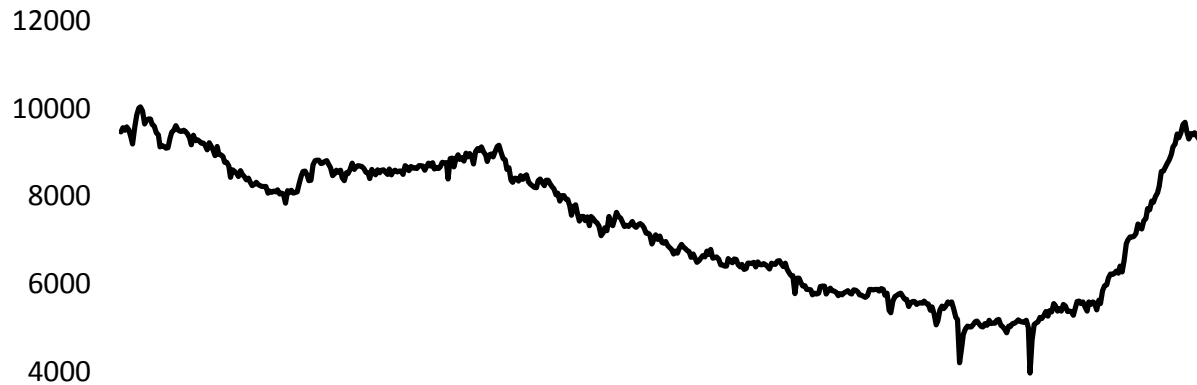

2000

0

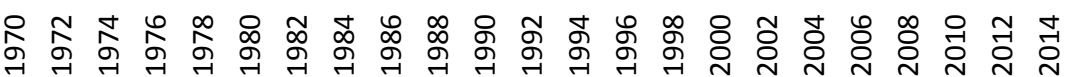

— Havi átlagos kitermelés (ezer hordó/nap)

Forrás: EIA.

A fejlesztéseket, beruházásokat nagyban ösztönözte a stabilan magas olajár, így a piacon mára túlkínálat alakult ki. Ugyanakkor közép és hosszú távon a legtöbben visszapattanásra, az árak emelkedésére számítanak, amit a spotot meghaladó határidős árakból (contango) lehet kiolvasni. Így a Hamilton [2009a] által emített spekulációs kereslet is megjelent, azaz a finomítóknak érdekükben áll feltölteni saját készleteiket, hogy a magasabb árak időszakában is a mai olcsó olaj előnyeit élvezhessék. Emellett arbitrázslehetőség nyílt azzal, hogy a határidős áron történő értékesítés bizonyos esetekben meghaladta az olaj „,azonnali” megvételének, tárolásának, és az ügylethez igénybe vett hitel kamatkiadásainak összesített költségét. Ennek következtében az amerikai kereskedelmi nyersolaj készletek szintje az amerikai energiahivatal (EIA) által 1982 óta vezetett statisztika alapján történelmi magasságokba emelkedett (14. ábra), 2015. december 11-én már 490 millió hordón állt ${ }^{31}$.

\footnotetext{
${ }^{31}$ A készletek volumene valójában ennél magasabb, mivel a statisztika nem veszi figyelembe a stratégiai olajtartalékokat (SPR, Strategic Petroleum Reserves) és a kereskedelmi készletek egy részét (pl. az olajvezetékekben tárolt volument).
} 


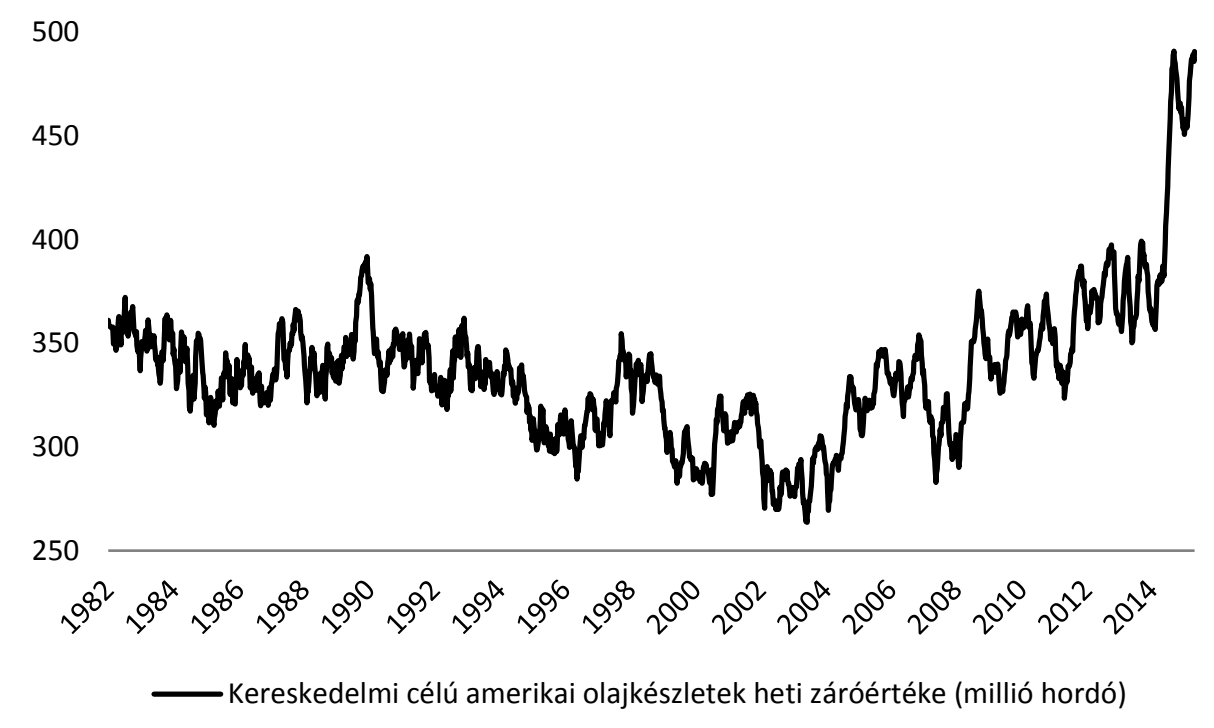

Forrás: EIA.

Az OPEC-en kívüli termelés felfutása nem először veti vissza az árakat, az 1980-as évek során gyakorlatilag ugyanez történt. Most a dollár erősödése, a kínai gazdasági növekedés lassulása, valamint a bizonytalan japán és európai gazdasági kilátások már csak ráerősítettek a folyamatra. A két helyzet között az igazi különbséget az OPEC viselkedése jelenti, ami a múltbeli tapasztalatokból okulva ezúttal nem próbálja a kitermelés visszafogásával mesterségesen magasan tartani az árakat. Ennek oka, hogy bár a kartell számos tagja (például Venezuela, Irak, Irán vagy Nigéria) érdekelt a kínálat csökkentésében, ök maguk ehhez nem tudnának hozzájárulni, mivel költségvetési bevételeik jelentős része az olaj exportjából származik. Valójában számos OPEC-tag költségvetési egyensúlya felborul 100 dollár/hordó alatti áraknál (IMF [2014], [2015]), ahogy azt a 2. táblázat is mutatja. Ebben a költségvetési egyensúlyhoz szükséges olajár időbeli alakulása látható a főbb közel-keleti és észak-afrikai kitermelők esetén (az OPEC tagországok félkövérrel szedve). A határértékek dinamikájából két további következtetés is levonható:

- a küszöbszint 2009-től kezdve folyamatosan emelkedett, amit az országok növekvő jóléti kiadásai magyaráznak (részben az arab tavasszal összefüggésben), így a csökkenő bevételek ellentételezéseként hiába tủnik természetes reakciónak a kormányzati vásárlások és transzferek mérséklése, annak gyakorlati kivitelezése politikailag kockázatos 
- ennek megfelelően, bár 2015-2016-ra a breakeven ár növekedése több ország esetén is megállt ${ }^{32}$, a felsorolt gazdaságokban - Kuvait kivételével - továbbra is szinte biztosra vehető a költségvetési deficit

2. táblázat: A költségvetési egyensúlyhoz szükséges olajár néhány közel-keleti és északafrikai exportőrnél (USD/hordó, nominál)

\begin{tabular}{|c|c|c|c|c|c|c|c|c|}
\hline & $\mathbf{2 0 0 9}$ & $\mathbf{2 0 1 0}$ & $\mathbf{2 0 1 1}$ & $\mathbf{2 0 1 2}$ & $\mathbf{2 0 1 3}$ & $\mathbf{2 0 1 4}$ & $\mathbf{2 0 1 5}$ & $\mathbf{2 0 1 6}$ \\
\hline Algéria & 79,2 & 85 & 109,7 & 120,9 & 108,1 & 133,8 & 96,1 & 93 \\
\hline Bahrein & 82,5 & 102,8 & 110,7 & 119,4 & 125,3 & 122,5 & 107 & 105 \\
\hline Irán & 65 & 76 & 84 & 130 & 115,8 & 94,2 & 87,2 & 70,4 \\
\hline Irak & 72,3 & 90 & 95 & 102,1 & 114,6 & 112,5 & 81 & 75,9 \\
\hline Kuvait & 28 & 47,5 & 39,1 & 49 & 43,6 & 56 & 49,1 & 51,8 \\
\hline Líbia & 54,6 & 57,7 & 124 & 65,3 & 110,8 & 206 & 269 & 207,6 \\
\hline Omán & 61,1 & 66,6 & 77,9 & 79,8 & 98,3 & 108,2 & 94,7 & 97,5 \\
\hline Katar & 26,7 & 76 & 79 & 69,2 & 60 & 56,3 & 55,5 & 57,8 \\
\hline Sz.-Arábia & 73,6 & 69,5 & 78,1 & 77,9 & 89 & 105,7 & 105,6 & 95,8 \\
\hline E. A. E. & 107,4 & 83,5 & 93,8 & 77,9 & 69,4 & 78,4 & 72,6 & 67,5 \\
\hline Jemen & 138 & 130 & 195 & 237 & 214,8 & 160 & 314 & 304 \\
\hline
\end{tabular}

Forrás: IMF [2014], [2015].

Megjegyzés: a 2009-2012-es értékek forrása IMF [2014], míg a 2013-2014-es becsléseké, valamint a 20152016-os projekcióké az IMF egy későbbi (IMF [2015]) kiadványa. Az OPEC tagországok félkövér kiemeléssel szerepelnek.

Ilyen körülmények között a kínálat mesterséges csökkentése csak a legnagyobb kitermelőktől, azon belül is Szaúd-Arábiától várható. Tulajdonképp ez a forgatókönyv valósult meg az 1980-as években, de akkor az árakat nem sikerült magasan tartani, és a stratégia egyetlen eredménye a szaúdiak világpiaci részesedésének visszaesése lett: míg az 1980-as évek elején még a globális kínálat 17\%-a származott az arab monarchiából, 1985-re ez 6,4\%-ra zsugorodott. Az 1986-os stratégiaváltás után is évekbe tellett a visszakapaszkodás, ám a régi dominancia sosem tért vissza. 1990-ben sikerült átlépni a 10\%-os küszöböt, azóta pedig végig a 12-14\%-os sávban ingadozott a szaúdi olaj hányada.

\footnotetext{
${ }^{32}$ Látványos kivételek Jemen és Líbia, ahol a háborús helyzet eszkalálódása vezetett a költségvetési egyensúlyt biztosító olajár emelkedéséhez.
} 
15. ábra: Szaúd-Arábia részesedése a világ olajkínálatából (1980-2014)

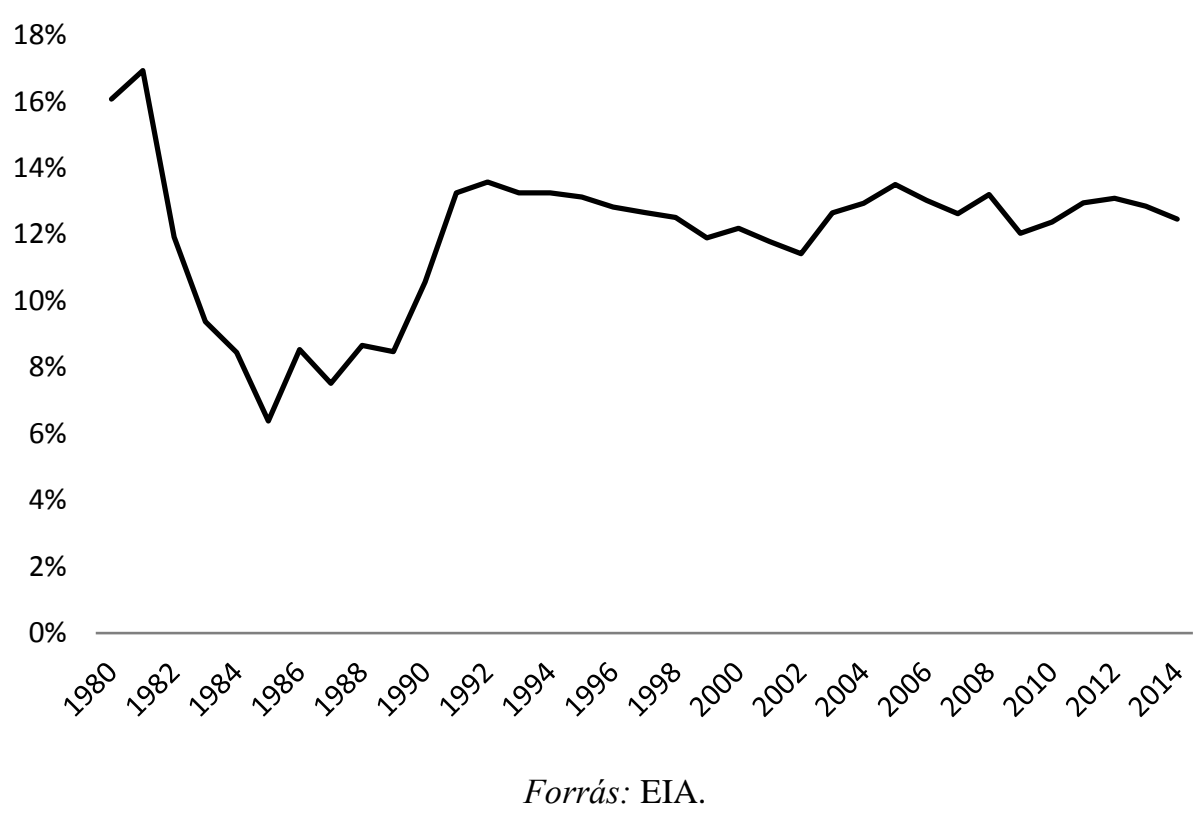

A múlt tapasztalataiból kiindulva, a vezető OPEC tagországok ezúttal nem próbálkoztak a termelés visszafogásával, mivel ezzel a probléma elsődleges forrását, a növekvő nem konvencionális kitermelést hozták volna helyzetbe. Ehelyett hagyták, hogy az árak akár saját breakeven szintjeik alá essenek, kizáró árazási stratégiába kezdtek, a kitermelés visszafogása helyett a piaci részesedés megtartására törekedtek ${ }^{33}$.

A kizáró árazás sikeréhez szükséges feltételeket Milgrom és Roberts [1982] modellje alapján határozhatjuk meg. Ök ugyanis egy olyan kétidőszakos problémát vizsgálnak, ahol az első időszakban egy nem megfigyelhető költségfüggvényű monopólium van a piacon, míg a második periódusban egy kívülálló dönthet a belépésről. Az alacsony határköltségü monopólium optimális stratégiája az, ha az első időszakban lenyomja az árakat, ezzel jelezve, hogy olcsón tud termelni, a másik vállalatnak pedig nem érdemes versenyeznie. Ehhez olyan árat kell megszabnia, amelyre igaz, hogy egy drágán termelő monopóliumnak az ebből származó első időszaki - monopol esethez viszonyított vesztesége már meghaladná a második időszaki monopol profitból származó - duopol esethez viszonyított - nyereségét. Azaz olyan jelzést kell küldenie, amivel hihető fenyegetésként azt üzeni, hogy duopólium kialakulása esetén az új belépő alacsony piaci árak - és negatív profit - mellett lenne kénytelen müködni. A jelenlegi olajpiaci helyzet több ponton is eltér a modell feltételeitöl, hiszen a piac szerkezete és a probléma

${ }^{33}$ Erröl a 2014.11.27-i ülésükön döntöttek. 
dinamikája jóval összetettebb, ugyanakkor az OPEC lépései egyértelműen az új belépők ellen irányulnak ${ }^{34}$. Így korlátozottan ugyan, de felhasználhatjuk Milgromék eredményeit a kizáró árazás sikeréhez szükséges feltételek meghatározásánál:

- Az OPEC-en kívüli - elsősorban észak-amerikai - termelőknek ne érje meg újabb beruházásokba kezdeniük, azaz a piaci részesedés megtartását célzó OPEC stratégia mellett a projektek által generált cash-flow ne biztosítsa a megtérülést (ne érje meg belépni, és az olcsón termelö kartelltagokkal versenyezni).

- Az OPEC részéről hihető fenyegetés legyen, hogy később is hajlandó ehhez az eszközhöz nyúlni, amennyiben egyszer mégis emelkedésnek indulnának az árak. Azaz a drágulás később se ösztönözze a kartellen kívüli szereplők beruházásainak masszív felfutását (tehát az OPEC-nek a jövőben is olcsóbb legyen a kizáró árazás eszközéhez folyamodnia, mint engedni az új szereplök piacralépését).

Mindkét pont számos kérdést vet fel. Rögtön az elsőnél abba a problémába ütközünk, hogy a palaolaj kitermelési költsége nem egységes, vállalatonként, mezőnként változik. Az országokhoz hasonlóan itt is létezik a breakeven árak fogalma, ami ezúttal a „kellően” nyereséges termeléshez szükséges árszintet jelöli. A 16. ábrán a viszonyítási pont a 9\%os adózás utáni hozamot takarja. Bár az ilyen típusú becslések mindig bizonytalanok, megállapítható, hogy még hordónként 60 dollár alatti árakon is számos projekt marad profitábilis, gyakran még úgy is, ha a 16. ábrán lévő árakhoz hozzáadjuk a hordónként 5 10 dolláros - a földterület megvásárlását, infrastruktúrális fejlesztéseket stb. - tartalmazó elsüllyedt költségeket ${ }^{35}$. A technológia rugalmassága miatt (fél-egy éven belül is el lehet indítani a kitermelést, és egy-egy mező életciklusa meglehetősen rövid) a kilépések, halasztások egyébként is csak addig tartanak, amíg az árak vissza nem emelkednek a kívánt szintre. Ez pedig azt is jelenti, hogy nem lehet olyan hihető fenyegetéssel élni, ami a palaolaj további térnyerését megakadályozná. A termelés felfutását csak lassítani, átmenetileg megtörni lehet, végérvényesen megfordítani már nem. Valószínűleg ez a megfontolás vezette az arab olajmonarchiákat, és stratégiájukkal a hosszú távú árcsökkenés mértékét igyekeznek tompítani, a versenytársak számát/kapacitását mérsékelni.

\footnotetext{
${ }^{34}$ Elvileg a már futó projekteket is leállásra kényszeríthetik, ennek esélyét azonban csökkenti, hogy a termelési kiadások egy része elsüllyedt költségként jelentkezik (kutatás, próbafúrás, olajfúró platform és szállítási infrastruktúra kiépítése stb.).

${ }^{35}$ Ráadásul 2014 ősze óta az észak-amerikai breakeven árak tovább süllyedtek, így a palaolaj termelőket még nehezebb kiszorítani a piacról.
} 


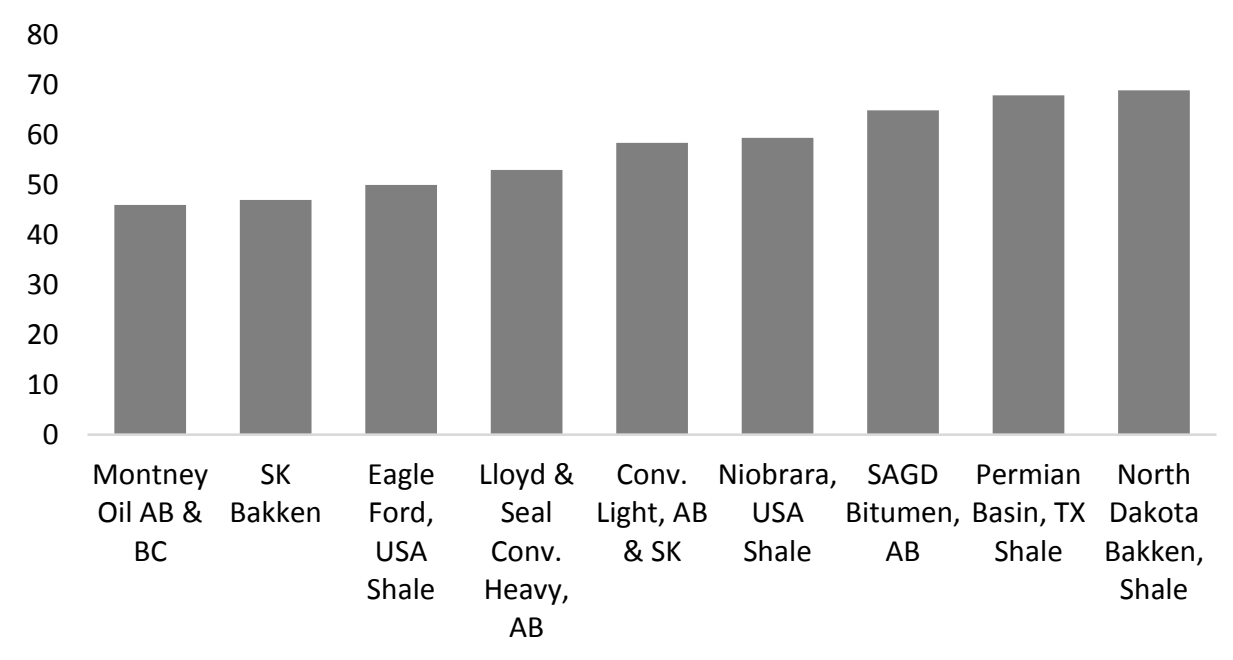

Breakeven ár (9\%-os adózás utáni hozammal, elsüllyedt költségek nélkül)

Forrás: Scotiabank Equity Research \& Scotiabank Economics.

\section{II.3.2. Makrogazdasági hatások}

Kérdés, hogy a korábban megszokottnál permanensen alacsonyabb olajárak milyen makrogazdasági hatással bírnak. Ezt legjobb esetben is csak pár év múlva tudjuk megválaszolni, azonban érdemes néhány aspektust közelebbről is megvizsgálni.

Arezki és Blanchard [2014] szerint a főbb hatások az alábbiak:

- Az importőr országokban nő a háztartások jövedelme, csökkennek az input költségek, és javul a gazdaságok külső pozíciója. Ez pozitívan hat a GDP-re, és azon országok kapják a legnagyobb stimulust, amelyeknél relatíve magas az energiafogyasztás GDP-n belüli aránya. A szerzők Kínát emelik ki, ahol az olajfogyasztás/GDP hányados 2004 és 2014 közötti átlagos értéke 5,4\% volt, szemben az Egyesült Államok 3,8\%-os mutatójával. Így az optimista szcenárió szerint 2015-2016 során az árcsökkenés hatása ceteris paribus akár 0,7-0,9 százalékponttal is gyorsíthatja a kínai bruttó hazai termék bővülési ütemét.

- Az USA, Japán és az euróövezet is többletnövekedéssel és alacsonyabb inflációval számolhat, azonban utóbbinak a deflációs környezetben akár negatív hatásai is lehetnek, főleg úgy, hogy a monetáris politika már kimerítette hagyományos eszköztárát, az alapkamatok $0 \%$-on vagy annak közelében tartózkodnak. 
- Az olcsó olaj pozitív hatását tompítja az importőr országok valutáinak dollárral szembeni leértékelődése, az energiát terhelő specifikus adók, valamint az exportőrökkel fennálló erős külkereskedelmi kapcsolat.

- Az exportör országok jelentős bevételcsökkenéssel számolhatnak, és a költségvetésre, illetve a külső egyensúlyra vonatkozó negatív hatás annál erősseb, minél inkább az olajbevételekre támaszkodik az államháztartás.

Az Egyesült Államokkal kapcsolatban megjegyzendő, hogy bár Arezki és Blanchard a különböző szcenáriókban 0,2-0,5 százalékpontra teszi a 2015-ös, és 0,3-0,6 százalékpontra a 2016-os többletnövekedést, Brown és Yücel [2013] megmutatta, hogy az USA régiói nem egységesen reagálnak az olajárak változására. Ennek oka, hogy tagállami szinten számos nagy termelővel találkozunk, így az érintett helyeken a foglalkoztatás, a GDP és a költségvetési bevételek egyaránt csökkennek. Ennek következtében az alábbi tagállamokat érintheti negatívan az árak esése: Alaszka, ÉszakDakota, Louisiana, Nyugat-Virginia, Oklahoma, Texas, Új-Mexikó és Wyoming. A Kalman-szürővel nyert eredmények is arra engednek következtetni, hogy az amerikai kitermelés felfutásával párhuzamosan egyre erősebbek az olajár esésének negatív hatásai. Mivel a 2014 közepén indult csökkenés elsősorban negatív specifikus keresleti sokkok következménye, érdemes felidézni a 11. ábrán látottakat. Ezek szerint az esés rövid távon dezinflációs és recessziós hatással, a munkanélküliség növekedésével jár együtt. A 2015ös tényadatokból kiindulva megállapítható, hogy az inflációs környezet valóban lassan javul, az év során jelentős eltérés mutatkozott a nyers és az energia, illetve élelmiszer áraktól szürt maginfláció között. Ellenben a GDP növekedése egy átmeneti - a mezőgazdasági termelés által okozott - megbicsaklástól eltekintve robusztus, és a munkaerő-piac állapota is javul. A reálgazdasági mutatók tehát nem a modell által várt irányba haladnak, ez azonban csak látszólagos ellentmondás: az olaj reálára csak egy, és ahogy láttuk, valószínűleg nem is a legfontosabb a számos növekedési tényező közül. Itt érdemes egy pillantást vetni az USA tagállami szintü munkanélküliségi rátáira. A 17. ábra a Brown és Yücel [2013] által megjelölt - egy áresés által negatívan érintett tagállamokra mutatja be, hogy 2014 és 2015 novembere között hány százalékponttal változott a munkanélküliségi ráta nagysága. Jól látható, hogy egyedül Louisiana tudott az országos átlagnál jobban szerepelni, összességében pedig a 17. legnagyobb csökkenést 
produkálta az 51 ,tagállam” között ${ }^{36}$. Ugyanakkor a többi esetben már nagy az elmaradás a teljes országra jellemző 0,8 százalépontos javulástól, és a lista utolsó 15 helyéből 7 a „veszélyeztetett” államokhoz tartozik. Különösen szembeszökő, hogy Oklahoma, Nyugat-Virginia és Új-Mexikó még a munkanélküliség növekedésével is szembe kell, hogy nézzen, miközben országos szinten erőteljes javulást, a munkaerö-piac feszességét mutató adatok kerülnek napvilágra. Bár ez csupán egy pillanatkép, mégis azt sejteti, hogy az időben változó paramétereknél látott dinamika valós, és ahogy enyhül az USA nettó importőri szerepe, úgy lehet ismét egyre erősebb az olajár makrogazdasági mutatókra gyakorolt befolyása. Ez a jelenség egyre nyilvánvalóbbnak tünik, Feyrer et al. [2015] például úgy becsülték, hogy az amerikai olaj és gázkitermelés 2005 és 2012 közötti felfutása a recesszió időszakában mintegy 0,5 százalékponttal mérsékelte a munkanélküliségi ráta szintjét, és 725 ezer fővel emelte a foglalkoztatottak számát. Ráadásul ez a becslés csupán a kitermelés következményeire fókuszált, figyelmen kívül hagyta a növekvő kínálat miatt olcsóbb gáz és olaj - az Egyesült Államok kitermelés által nem érintett területein jelentkező - kedvező hatásait, azaz valószínüleg alulbecsülte a palaolaj és palagáz forradalom munkaerö-piaci következményeit.

${ }^{36}$ Washington D.C. hivatalosan nem tagállam, de a listában ettől függetlenül szerepel. 
17. ábra: A munkanélküliségi ráta változása az Egyesült Államok egyes tagállamaiban (2014 és 2015 novembere között)

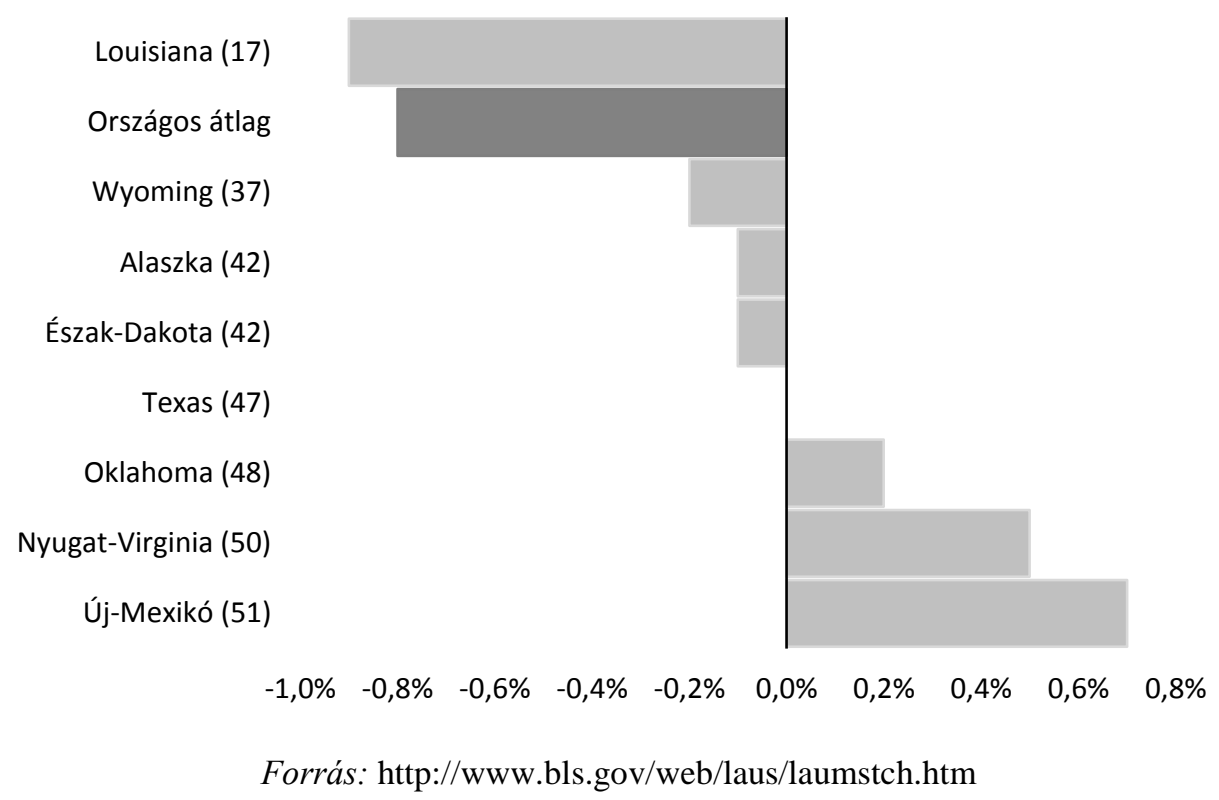

Megjegyzés: A vízszintes tengelyen az adott tagállam munkanélküliségi rátájának százalékpontos éves változása szerepel (2014. és 2015. november között). A zárójelben található érték mutatja, hogy a Washington D.C-t is beleértve 51 „tagállam” között hányadik helyet foglalja el a munkanélküliségi ráta csökkenésében. A lista a Brown és Yücel [2013] által az olaj árának csökkenésére leginkább érzékeny amerikai tagállamokat tartalmazza.

\section{II.4.: A fejezet összefoglalása}

A szakirodalom számos, az olaj árát befolyásoló tényezőt vizsgált: a háborúk okozta termeléskiesés, az OPEC ereje, a spekuláció és a globális kereslet változása mind-mind hozzájárulhattak az elmúlt 40 év volatilis áraihoz. Kezdetben az 1970-es évek olajválságait az őket követő stagflációk elsődleges okaként, azok közvetlen kiváltójaként állították be, ám az 1990-es évektől kezdve teret nyertek azok az elképzelések, amelyek szerint mindez a monetáris politikában bekövetkezett éles irányváltások következménye volt (Bernanke et al. [1997], Barsky és Kilian [2001]). Ezek az elméletek kisebb jelentőséget tulajdonítanak a magasabb ár inputköltségekre, várakozásokra, termelési szerkezetre vonatkozó hatásainak. Ugyanakkor az energiahordozó ára egyre kevésbé számít a makrogazdasági teljesítmény szempontjából (Blanchard és Galí [2007]). A fejezetben időben változó paraméterü ökonometriai modellek segítségével vizsgáltam ennek lehetséges kiváltó okait. Míg Blanchard és Gali [2007] a gazdaság strukturális változásaira, jobb ellenálló képességére vezette vissza a mérsékeltebb károkat, addig 
Kilian [2010] megmutatta, hogy a makrogazdasági hatások függnek az árváltozás szerkezeti összetételétől, és ezen mögöttes faktorok miatt tünik úgy, hogy az Egyesült Államok növekedési és inflációs mutatói ma már kevésbé érzékenyek az olajár emelkedésére, mint voltak az 1970-es vagy az 1980-as években. Ugyanakkor a két elmélet nem zárja ki egymást, és az itt bemutatott eredmények azt igazolják, hogy nem csupán az olajár emelkedés strukturális összetevői változtak az évtizedek folyamán, de az Egyesült Államok gazdasága is másképp reagál e faktorokra, mint tette azt 30-40 évvel ezelött. Bár ebböl még nem következik, hogy épp a Blanchard és Galí által megjelölt tényezők okozzák az ellenálló képesség növekedését, mindenesetre potenciális jelölteknek tekinthetők. Több jel is arra utal azonban, hogy az amerikai olajtermelés felfutása befolyásolja a sokkok makrogazdasági hatásainak előjelét és dinamikáját, és könnyen elképzelhető, hogy az előttünk álló években az árak abszolút hatásának erősödése lesz tapasztalható. 


\section{FEJEZET: Az olajár és a makrogazdaság kapcsolatának elemzése folytonos wavelet transzformáció segítségével - Svédország és Norvégia példáján}

A 2014 nyarán kezdődött olajár csökkenés számos termelő országnál eredményezett komoly kieséseket az export, illetve a kormányzati bevételekben. Azon szereplők, akik nem rendelkeztek megfelelő volumenü pénzügyi tartalékkal, még időlegesen sem voltak képesek ellensúlyozni a csökkenő jövedelmek negatív makrogazdasági hatásait, erős kiigazítási kényszerbe kerültek, gazdasági mutatóik, növekedési kilátásaik jelentősen romlottak. Ebben a környezetben gyakran merül fel az exportör országok éveken vagy akár évtizedeken át folytatott rossz gazdaságpolitikája, az olajártól való túzott függőség felszámolását, a gazdaság diverzifikációját célzó intézményrendszer kiépítésének elmaradása. A kevés kivételek egyike Norvégia, ahol egy erre a célra felállított alapba irányítják az olajtermeléshez kapcsolódó állami jövedelmeket, ezzel mérsékelve a nyersanyag jegyzésének volatilitásából eredő negatív következményeket és a makrogazdaságra egyébként is jellemző ciklikus ingadozásokat. A fejezet célja, hogy folytonos wavelet transzformációk segítségével vizsgálja a norvég gazdasági mutatók (CPI infláció, ipari termelés és bruttó hazai termék) olajárral való kapcsolatának erősségét, annak idő és frekvenciatérben történő alakulását. A különböző frekvencia tartományokban végzett elemzés előnye, hogy az idősoros megközelítésnél jóval komplexebb dinamikák feltárására ad lehetőséget, hasznos kiegészítést nyújtva a sztenderd eljárások mellé. Az összehasonlíthatóság kedvéért az olajimportőr, társadalmigazdasági berendezkedését tekintve a szomszédos Norvégiához sok tekintetben hasonló(nak gondolt) Svédország is a vizsgálat részét képezi. A fejezetben az alábbi kutatási kérdésekre keresem a választ:

1. Van-e relevanciája a frekvenciatérben történő elemzésnek?

2. A különböző frekvenciákon kimutatható-e az olajár és a vizsgált makrogazdasági mutatók kapcsolatának időbeli változása?

3. Ha igen, akkor milyen irányú/erősségü változásról beszélhetünk?

4. Elég-e önmagában az olajár vizsgálata? Mennyire befolyásolja az eredményeket a közös faktorok, például a világgazdasági konjunktúra hatásainak kiszürése?

5. Az eredmények alapján Norvégia képes volt-e függetleníteni gazdasági teljesítményét az olajár magas volatilitásától? 
A fejezet felépítése a következő. Az első alfejezetben röviden áttekintem a kapcsolódó közgazdasági irodalmat, a másodikban bemutatom a folytonos wavelet transzformációk megértéséhez szükséges módszertani elemeket, míg a harmadikban az elemzés során használt adatokkal ismerkedünk meg. A modellezési eredmények a negyedik, a potenciális fejlesztési irányok leírása az ötödik alfejezetbe került. Az utolsó, hatodik alfejezetben foglalom össze a tanulmány főbb megállapításait.

\section{III.1. Szakirodalom áttekintése}

Ahogy az a II. fejezetben részletesen ki lett fejtve, az olajár makrogazdasági hatásainak kutatása régóta népszerü területnek számít, és az elmúlt évtizedekben komoly fejlődésen ment keresztül. Kezdetben a közgazdászok csupán az árváltozás mértékéből indultak ki, és annak függvényében igyekeztek meghatározni a föbb makromutatókra gyakorolt befolyás nagyságát, valamint annak aszimmetriáját (Loungani [1986], Mork [1989], Lee et al. [1995], Hamilton [2003], Jimenez-Rodriguez és Sanchez [2005]). Később azonban Kilian [2009] eredményei alapján széles körben elfogadottá vált az a nézet, amely szerint nem az árváltozás, hanem az azt kiváltó tényezők elmozdulásának nagysága a kulcs. Szintén a II. fejezetben került bemutatásra, hogy részben ezért nem okozott stagflációt a 2000-es években tapasztalt nagy olajár emelkedés, hiszen azt az ázsiai kereslet élénkülése váltotta ki, ami olcsó exportjával, valamint a nyugati termékek iránti kereslet élénkítésével ellensúlyozni tudta a magasabb nyersanyag költségek negatív hatásait (Kilian [2010]). Blanchard és Gali [2007] ellenben az amerikai (és más fejlett) gazdaságok megnövekedett ellenálló képességének, többek között a monetáris politika hatékonyságjavulásának tulajdonította a mérsékeltebb károkat. Szintén a monetáris politika változására vezette vissza Aguiar-Conraira és Soares [2011] az olajár gyengülő makrogazdasági hatásainak eredetét. Ők folytonos wavelet transzformációk segítségével vizsgálták az amerikai inflációra és ipari termelésre vonatkozó hatásokat. Konklúziójuk szerint az összefüggés időben instabil, és az üzleti ciklusok (3-8 éves) frekvencia tartományában az olajár növekedése csökkenti az ipari outputot, míg ennél alacsonyabb (8-12 éves) frekvencia tartományban már pozitív kapcsolat van a két változó között, mégpedig az ipari kibocsátás vezető szerepével (az ipar bővülése megelőzi az olajár emelkedését). Az infláció esetén azt találták, hogy az olajár növekedése magasabb pénzromlási ütemmel járt együtt, és a nyersanyag árának változása időben megelőzte az 
árszínvonal emelkedését. Ez az összefüggés azonban sokat gyengült az 1980-as években, amit a Fed szigorúbb hozzállásával indokoltak.

E megállapítások azonban kizárólag importőr gazdaságokra vonatkoznak, az exportőrökről szóló irodalom jóval szükebb. Aleisa és Dibooglu [2004] az 1980-2000 közötti időszakra illesztett vektor-autoregresszív (VAR) modell segítségével becsülték meg az olajár sokkok makrogazdasági hatásait Szaúd-Arábia példáján. Ebben azt találták, hogy rövid távon Szaúd-Arábia szignifikánsan képes befolyásolni a reál olajárat, utóbbi pedig az aggregált kínálati sokkok után a legfontosabb tényező a szaúdi output volatilitása mögött. Emellett a reál árfolyam fluktuációjában, hosszú távon pedig a belföldi árszínvonal alakulásában is kiemelt szerepe van az olajnak, azaz a monarchia gazdasága érzékenyen reagál a nyersanyag árának kilengéseire. Ezért Aleisa és Dibooglu szerint a kitermelő országoknak gazdaságuk diverzifikálására, valamint az olajár stabilitásának elérésére kell törekedniük, máskülönben nem tudják elkerülni a külkereskedelmi cserearány változásából eredő kiszámíthatatlanságot, a makrogazdasági változók magas volatilitását. Mendoza és Vera [2010] is hasonló megállapításokra jutottak a venezuelai GDP és a reál olajár közti összefüggések vizsgálatakor. Ök Mork [1989], Lee et al. [1995], illetve Hamilton [2003] munkáira építve az olajár sokkok aszimmetrikus hatásait is vizsgálták. Konklúziójuk szerint a venezuelai GDP-t szignifikánsan emeli az árak nem várt növekedése, és egy csökkenés abszolút hatása kisebb, mint egy ugyanakkora volumenű emelkedésé. Azt is kimutatták, hogy a dél-amerikai gazdaság olajszektorának hozzáadott értéke kevésbé érzékeny a nyersanyag árának kilengéseire, amit azzal magyaráztak, hogy a kitermelési volumen Venezuelában alapvetően politikai (és technológiai) kérdés, miközben az olajszektor által megtermelt jövedelemből a többi ágazat is részesül, így azok teljesítménye sokkal inkább az olajbevételekhez van kötve. Bár Mendoza és Vera nem foglalkoztak eredményeik gazdaságpolitikai következményeivel, azokból egyértelműen a diverzifikáció fontossága olvasható ki. Ami az európai kitermelöket illeti, Benedictow et al. [2013] egy többegyenletes makroökonometriai modellkeretben vizsgálták az orosz gazdaság olajáraknak való kitettségét, és azt találták, hogy bár az olajszektor nélkül is rendelkezik szignifikáns növekedési potenciállal, az erőfeszítések ellenére a makrogazdasági teljesítmény érzékenyen reagál a fosszilis tüzelőanyag árában történő elmozdulásokra. E három példa nem számít kirívónak, több más termelő esetén is ki lehet mutatni, hogy a gazdaság olajszektoron és annak beszállító ágazatain kívüli része nemzetközi összehasonlításban 
jelentős versenyhátrányba került. Ezen a monetáris politika az árfolyamok rögzítésével, míg a fiskális hatóságok célzott támogatásokkal, tartalékalapok képzésével igyekeznek segíteni, változó hatékonysággal. Az intézményi reformok, a gazdasági diverzifikáció ugyanis nem helyettesíthető, csupán kiegészíthető a fenti intézkedésekkel. Mindez napjainkban különösen szembeszökő, hiszen az olajárak 2014 közepén kezdődött mélyrepülése több termelöt is megroppantott, a legrosszabb helyzetben pedig épp Venezuela találta magát, ahol 2014-ben az olaj értékesítéséből származott az exportbevételek 96, illetve a kormányzati jövedelmek 45\%-a. Arezki és Blanchard [2014] szerint az exportőr országok a mostanihoz hasonló mértékü árcsökkenésnél jelentős bevételkieséssel számolhatnak, és a költségvetésre, illetve a külső egyensúlyra vonatkozó negatív hatás annál erősseb, minél inkább az olajbevételekre támaszkodik az államháztartás. Ennek tükrében nem meglepő, hogy az IMF a 2015-ös World Economic Outlookban 2015-re 10, 2016-ra pedig 6\%-os visszaesést jósolt Venezuela GDP-jében.

Megjegyzendő azonban, hogy nem minden jelentős szénhidrogén vagyon felett diszponáló országra jellemző a nagymértékű kitettség. A legkézenfekvőbb példa talán Norvégia, ahol az 1960-as évek végén indultak meg a kutatások az Északi-tenger mélyén fekvő olajvagyon kiaknázására. Az ott talált készletek volumene lehetővé tette, hogy Norvégia mind a mai napig a világ egyik legnagyobb olajtermelője maradjon ${ }^{37}$, miközben az ebből származó bevételeket (adók, osztalékok, licence díjak) egy állami alapban (Norvég Kormányzati Nyugdíjalap) tartja, amivel egyrészt a jövő generációinak is juttat az olajvagyonból, másrészt igyekszik mérsékelni az ár fluktuációjából eredő kiszámíthatatlanságot. Ennek eredményeként más termelőkhöz képest kevésbé érzékeny az olajár változásaira. Bjornland [2000] például az 1967-1995-ös periódust vizsgálva arra jutott, hogy egy 10\%-os árcsökkenés 1 évvel később átlagosan 0,3-0,4 százalékkal mérsékelte a norvég GDP-t. Hasonló eredményre jutott Jimenez-Rodriguez és Sanchez [2005], illetve Peersman és Van Robays [2012] is, akik 0,2-0,3\%-os lassulást becsültek. Ugyanakkor, ahogy arra Kilian [2009] rámutatott, nem minden olajár sokk egyforma, és a forrás függvényében lehet csak megítélni a pontos hatásokat. Ez igaz Norvégiára is, ahol Bjornland és Thorsrud [2014] egy bayesi dinamikus faktor modell keretein belül különböztette meg az olajkínálati és az aggreált keresleti sokkok hatásait. Eredményeik

\footnotetext{
${ }^{37}$ Az Energy Information Administration (EIA) adatai szerint 2014-ben napi 1,9 millió hordós átlagos kitermelésével Norvégia a 15. helyet foglalta el a globális kínálati rangsorban. Az adatok forrása: http://www.eia.gov/beta/international/rankings/\#?prodact=53-1\&cy=2014
} 
szerint, amennyiben egy 10\%-os olajár csökkenést a kereslet visszaesése vált ki, úgy egyéb norvég exporttermékek fogyasztása is csökken, és a bekövetkezés után 1 évvel a GDP átlagosan 0,8-1\%-kal alacsonyabb szinten fog tartózkodni az alappályához képest. Ezzel szemben, ha a kínálat emelkedése okozta a 10\%-os árcsökkenést, akkor az olajimportőr országoknál keletkező többletjövedelem egy része a norvég exporttermékek vásárlásában csapódik le, így a GDP-re gyakorolt negatív hatás mintegy 0,2\%-ra mérséklődik.

Megállapítható tehát, hogy az olajár változására különböző módon reagálnak az importőr és az exportőr gazdaságok, ráadásul az importőrök esetén ezek a hatások időben egyre gyengültek. Bjornland és Thorsrud [2014] alapján pedig van legalább egy olyan termelő ország (Norvégia), ahol a makrogazdasági következményeket a sokkok eredete határozza meg. Mivel az olajár változását időben más és más faktorok befolyásolták, könnyen elképzelhető, hogy az exportőröknél is a makrogazdasági hatások gyengülését/erősödését figyelhetjük meg. E fejezet egyik célja, hogy néhány kezdeti lépést tegyen ennek feltárására, mégpedig az olajár/az olajárat mozgató sokkok és a főbb makrogazdasági változók együttmozgásának vizsgálata révén. Ehhez Norvégia és Svédország eseteit fogom felhasználni, ugyanis a két skandináv ország közül csak az előbbi rendelkezik jelentős mennyiségű szénhidrogén kinccsel, míg utóbbi összehasonlítási alapként szolgál majd. A tanulmány másik célja, hogy ehhez a közgazdasági kutatásokban egy eleddig ritkán alkalmazott, ám komoly potenciállal rendelkező módszertan használatát is prezentálja. A folytonos wavelet transzformációk ugyanis a megszokott idősoros technikák hasznos kiegészítőjeként szolgálhatnak, lehetővé téve, hogy mélyebben, a frekvenciák szintjén is vizsgálódjunk. E metódus révén egyszerre lehet feltárni a folyamatok különböző frekvenciákon mért együttmozgásának erősségét, valamint annak időbeli változását.

\section{III.2. Módszertan}

A kapcsolódó empirikus elemzések jellemzően valamilyen idősoros vagy egyensúlyi megközelítéssel dolgoznak. Kilian [2009], Li és Zhao [2011], illetve Baumeister és Peersman [2013] strukturális VAR modellekkel, míg Peersman és Stevens [2010], Bodenstein et al. [2012] DSGE keretben vizsgálták az olajár makrogazdasági változókra gyakorolt hatását. Ezen eljárások hátránya, hogy nem képesek a frekvenciák kezelésére. Előfordulhat például, hogy az olajár rövid távú kilengései nem okoznak változást a 
vizsgált makrogazdasági változók mozgásában, míg a hosszú távú trendek meghatározó erővel bírnak. Erre mutatott rá Aguiar-Conraira és Soares [2011] említett kutatása is, mégpedig a folytonos wavelet transzformációk segítségével. A waveleteket közgazdasági területre először Ramsey és Lampart vezették be, akik a pénzkínálat és a GDP (Ramsey és Lampart [1998a]), valamint a jövedelem és a fogyasztás (Ramsey és Lampart [1998b]) közötti kapcsolatot vizsgálták különböző frekvencia tartományokban a diszkrét wavelet transzformáció (DWT) segítségével. A folytonos változatot (continuous wavelet transform, CWT) csak később kezdték el használni. Az üzleti ciklusok vizsgálatára Crowley és Mayes [2008], Rua [2010], [2012], Rua és Silva Lopes [2012] alkalmazták ezt a megközelítést, míg Rua és Nunes [2009] a tőzsdei hozamok együttmozgását elemezték vele. A CWT-be alapos bevezetést nyújt Aguiar-Conraira és Soares [2014] tanulmánya, ahol konkrét példák (az amerikai inflációs környezet változásának, a nagy tőzsdeindexek együttmozgásának, valamint az olajár és az amerikai S\&P 500 tőzsdeindex kapcsolatának) bemutatásán túlmenően egy MATLAB toolbox ${ }^{38}$ is kidolgozásra került. Az empirikus elemzések elvégzéséhez én is ezt fogom használni.

\section{III.2.1. Folytonos wavelet transzformáció}

A közgazdaságtanban eddig is volt példa a frekvenciatérben történő vizsgálatra, elsősorban az idősorok trend, ciklus és szezon tényezőkre történő szétválasztásánál (Baxter és King [1999], Christiano és Fitzgerald [2003]). Ugyanakkor a Fourier transzformáción alapuló eljárások egy komoly hátránnyal bírnak, nem veszik figyelembe az idő dimenziót. A Fourier transzformáció egy x $(\mathrm{t})$ idősort különböző frekvenciájú sinus és cosinus függvények aggregáltjaként állít elő, így végeredményben arra ad választ, hogy a változó alakulása mennyiben köthető az egyes frekvenciákhoz:

$$
F_{x}(\omega)=\int_{-\infty}^{\infty} x(t)[\cos (\omega t)-\mathrm{i} \cdot \sin (\omega t)] d t
$$

\footnotetext{
${ }^{38} \mathrm{https}: / /$ sites.google.com/site/aguiarconraria/joanasoares-wavelets/the-astoolbox
} 
Ahol $\omega$ az ún. körfrekvencia (angular frequency) ${ }^{39}$. Ahogy a képletből is látható, a végeredmény nem függ t-től, így kénytelenek vagyunk lemondani az idő dimenzió vizsgálatáról, a formula az időben változó frekvenciájú idősorok elemzésére nem alkalmas. Ennek kezelésére megoldást nyújthat a rövid távú Fourier transzformáció, aminek lényege, hogy az idősíkot azonos hosszúságú blokkokra bontja, majd ezekre az ablakokra külön-külön elvégzi a Fourier transzformációt. Ugyanakkor ez az eljárás is rendelkezik egy nagy hiányossággal. Minél szükebbek az ablakok, annál nehezebb észlelni az alacsony frekvenciájú részeket, míg széles ablakok mellett az időbeli változás felderítése romlik. A wavelet analízis lényege, hogy megpróbál jobb, az elemzési célnak megfelelöbb egyensúlyt teremteni, és az ablakok szélességét a vizsgált frekvencia tartományoknak megfelelően mozgatja. Illusztrációként Rua [2012] 1. ábráját generálom újra (18. ábra). Ebből kitünik, hogy:

- Az idősoros eljárások tökéletesen leképezik a folyamatok időbeliségét, de egyáltalán nem veszik figyelembe a frekvencia tartományt (egy-egy időpontban aggregálja az összes frekvencián elérhető információt).

- A Fourier transzformáció tökéletesen leképezi az idősort egy frekvenciatérbe, de az időbeli alakulásról semmit nem mond (egy-egy frekvencián aggregálja az összes időpont információját).

- A rövid távú Fourier transzformáció a kettő között helyezkedik el, és mind az időbeli változások, mind a különböző frekvenciák kezelésére alkalmas, ugyanakkor egyiket sem tudja tökéletesen elvégezni (trade-off jelentkezik).

- A wavelet transzformáció úgy kezeli a rövid távú Fourier transzformáció rugalmatlanságát, hogy a magasabb frekvenciák vizsgálatára szükebb, az alacsonyabb frekvenciákéra pedig szélesebb ablakot használ, így kevesebbet kell feladni az egyes dimenziók mentén mért pontosságból.

\footnotetext{
${ }^{39}$ A körfrekvencia a frekvencia $2 \pi$-vel történő felszorzása révén áll elő.
} 
18. ábra: Az idő-frekvencia tulajdonságok összehasonlítása (Rua [2012] alapján)
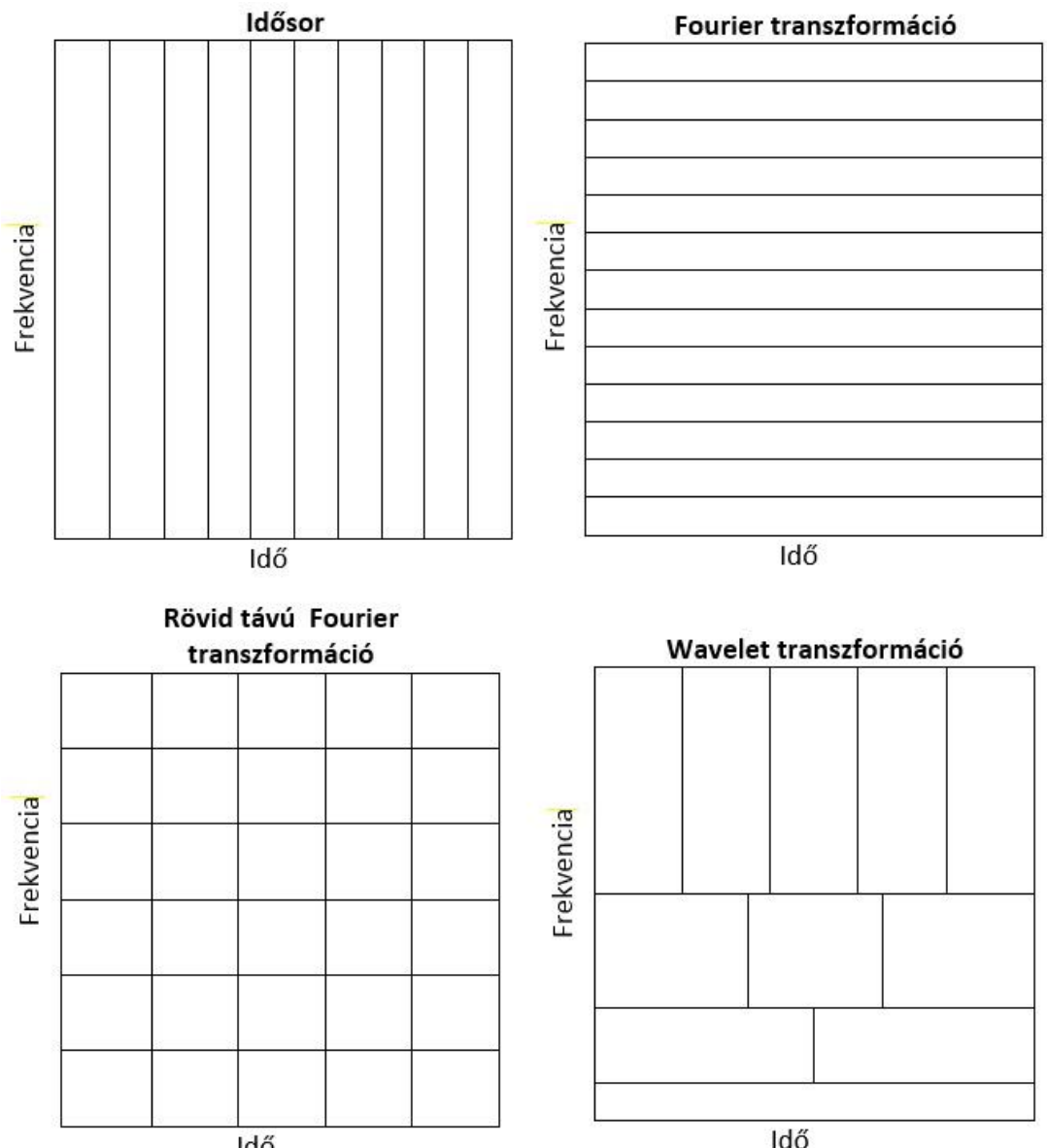

Forrás: saját szerkesztés.

$\mathrm{Az} x(\mathrm{t})$ négyzetesen integrálható idősor folytonos wavelet transzformáltja $\tau$ időpontban, $s$ szélességü ablak mellett ${ }^{40}$ :

$$
W_{x}(\tau, s)=\int_{-\infty}^{\infty} x(t) \psi_{\tau, s}^{*}(t) d t
$$

Ahol $\psi_{\tau, s}(t)$ jelöli a waveletet, * pedig annak komplex konjugáltját, emellett teljesül, hogy $s, \mathcal{T} \in \mathbb{R}, s \neq 0$. A wavelet az ún. anya waveletből $(\psi(\cdot))$ áll elö, mégpedig a következő formában:

\footnotetext{
${ }^{40}$ A fejezet során végig ún. analitikus (vagy progresszív) waveletekkel dolgozom, amelyekre igaz, hogy komplex függvények, és Fourier transzformáltjuk negatív körfrekvencia esetén nulla $(\Psi(\omega)=0 \forall \omega<0$ ra). Így a wavelet transzformáció is csak pozitív skálaparaméterek mellett kerül kiszámításra $(s>0)$.
} 


$$
\psi_{\tau, s}(t)=s^{-0.5} \psi\left(\frac{t-\tau}{s}\right)
$$

Az $s$ skálaparaméter értéke fogja meghatározni, hogy mennyire széles ablakkal dolgozunk. Alacsony $s$ esetén az ablak szük, és a magas frekvenciájú részek identifikálásra alkalmas, míg magas $s$ mellett az ablak széles, és az alacsony frekvencia elemzésére használható ${ }^{41}$. Ahhoz, hogy valami anya (elemző) wavelet legyen, egyrészt négyzetesen integrálhatónak kell lennie $\left(\psi(\cdot) \in L^{2}(\mathbb{R})\right)$, másrészt teljesítenie kell az ún. elfogadhatósági kritériumot:

$$
0<\int_{-\infty}^{\infty} \frac{|\Psi(\omega)|}{|\omega|} d \omega<\infty
$$

Ahol $\Psi$ a $\psi$-hez tartozó Fourier transzformált. A közgazdasági alkalmazásokban leggyakrabban használt anya wavelet az ún. Morlet wavelet (Goupillaud et al. [1984]) ${ }^{42}$ :

$$
\psi(t)=\frac{\pi^{-0.25} e^{-0.5 t^{2}}}{\cos \left(\omega_{0} t\right)-\mathrm{i} \cdot \sin \left(\omega_{0} t\right)}
$$

Ahol $\omega_{0}$ megválasztásával tudjuk alakítani, hogy mennyire precíz felbontást szeretnénk kapni frekvencia/idő tekintetében. Alacsonyabb érték mellett rosszabb frekvencia, de jobb időbeli felbontást kapunk, míg a paraméter növelése épp ellentétes hatást vált ki. Az alkalmazások során a kapcsolódó irodalomban szokásos $\omega_{0}=6$ feltevéssel élek ${ }^{43}$.

A Morlet wavelet grafikus megjelenítése a 19. ábrán látható. Ebből az is világossá válik, miből származik a wavelet („,kis hullám”, „hullámocska”) elnevezés: pár alkalommal a függvény 0 körül oszcillál, majd a (+/-) végtelenben 0-hoz tart.

\footnotetext{
${ }^{41}$ Ahogy a képletből már látható, itt is jelentkeznek a végponti problémák, ugyanis bizonyos időpontokban az ablak mérete már túlmutat a mintán. Minél alacsonyabb frekvenciát vizsgálunk, annál nagyobb a skálaparaméter értéke, így annál nagyobb időszakot érint ez a probléma. Ennek kezelésére Aguiar-Conraira és Soares [2014]-et követve a hiányzó adatokat nullának tekintem, és az ábrákon egyértelműen feltüntetem az érintett részeket. Ezekben az esetekben az eredmények pontossága fenntartásokkal kezelendő.

${ }^{42}$ Megjegyzendő, hogy a Morlet wavelet valójában nem teljesíti az elfogadhatósági kritériumot, ahhoz egy plusz korrekciós tag is szükséges. Ugyanakkor gyakorlati alkalmazások során elég, ha kellően nagy $\omega_{0}$ választunk (Foufoula-Georgiou és Kumar [1994]).

${ }^{43}$ Aguiar-Conraira és Soares [2014] szerint az összes általuk ismert közgazdasági alkalmazásban Morlet waveletet használtak $\omega_{0} \epsilon[5 ; 6]$ beállítással. Az $\omega_{0}=6$ választás elönye, hogy könnyebbé teszi az eredmények interpretációját, mivel a frekvencia és a skála közti összefüggés az $\mathrm{f} \approx 1$ /s alakra egyszerüsödik.
} 
19. ábra: A Morlet wavelet

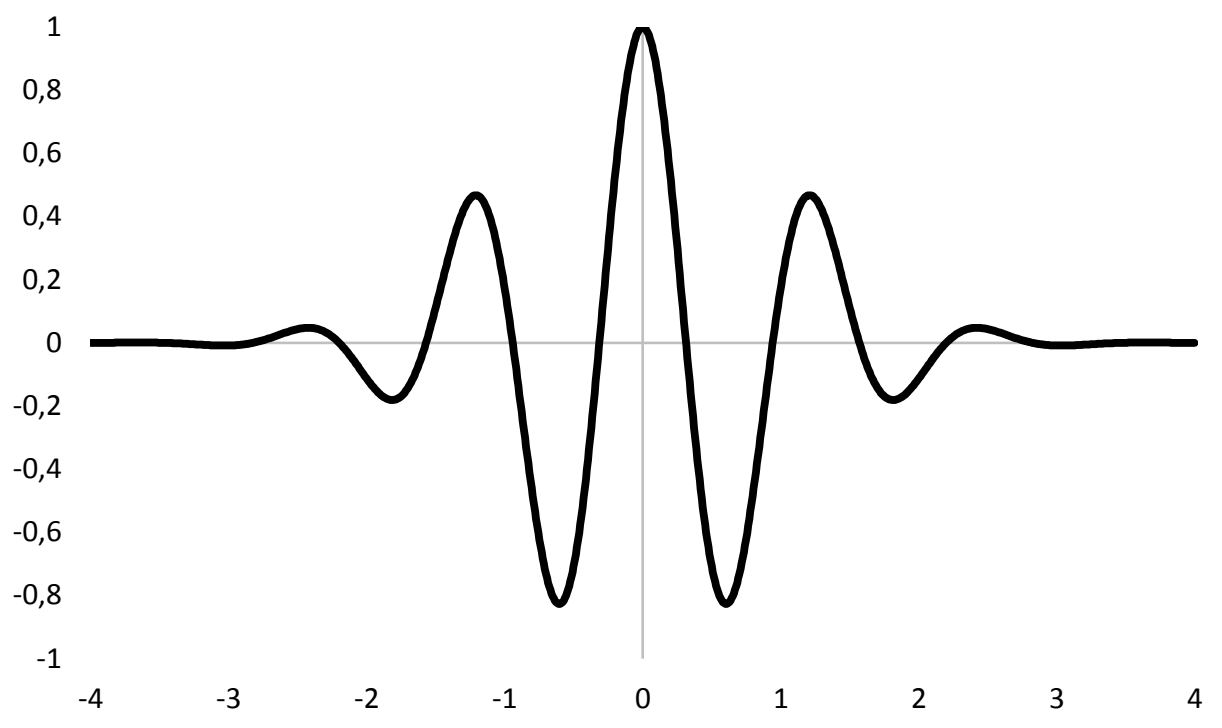

Forrás: saját szerkesztés.

\section{III.2.2. Az együttmozgás mérése}

A különböző idősorok wavelet transzformációiból az együttmozgást az idődimenzió mellett a frekvenciatérben is nyomon követhetjük a wavelet koherencia segítségével:

$$
R_{x, y}(\tau, s)=\frac{\left|S\left(W_{x, y}(\tau, s)\right)\right|}{\left\{S\left[\left|W_{x}(\tau, s)\right|^{2}\right] S\left[\left|W_{y}(\tau, s)\right|^{2}\right]\right\}^{0.5}}
$$

Ahol $R_{x, y}(\tau, s)$ és $W_{x, y}(\tau, s)$ az x és y idősorok közötti wavelet koherencia és kereszt wavelet transzformált $\tau$ időpontban $s$ skálaparaméter mellett, $S($.) pedig a simítási függvény ${ }^{44}$. A kereszt wavelet transzformált definíciója (Hudgins et al. [1993]):

$$
W_{x, y}(\tau, s)=W_{x}(\tau, s) W_{y}^{*}(\tau, s)
$$

A wavelet koherencia értéke 0 és 1 között bármit felvehet, és minél nagyobb, annál erősebb együttmozgást jelöl (akár azonos, akár ellentétes irányba). Ennek kiegészítéseként lehetőség van az egyes frekvenciák közti együttmozgás

${ }^{44}$ Hamming ablak (Harris [1978]). 
szignifikanciájának ${ }^{45}$, illetve a késleltetési struktúrának a vizsgálatára. Utóbbit az ún. fáziskülönbség segítségével végzem ${ }^{46}$ :

$$
\phi_{x, y}(\tau, s)=\arctan \left(\frac{\mathfrak{I}\left(S\left(W_{x, y}(\tau, s)\right)\right)}{\mathfrak{R}\left(S\left(W_{x, y}(\tau, s)\right)\right)}\right)
$$

Ahol $\mathfrak{I}(\cdot)$ jelöli az imaginárius, $\mathfrak{R}(\cdot)$ pedig a valós részt. A fáziskülönbség értéke a $[-\pi ; \pi]$ intervallumba esik, és a következő késleltetési struktúrákat jelöli:

- $\phi_{x, y}(\tau, s) \in\left(-\pi ;-\frac{\pi}{2}\right)$ : negatív kapcsolat (out-of-phase), $\mathrm{x}$ vezet

- $\phi_{x, y}(\tau, s) \in\left(-\frac{\pi}{2} ; 0\right)$ : pozitív kapcsolat (in-phase), y vezet

- $\phi_{x, y}(\tau, s) \in\left(0 ; \frac{\pi}{2}\right)$ : pozitív kapcsolat (in-phase), $\mathrm{x}$ vezet

- $\phi_{x, y}(\tau, s) \in\left(\frac{\pi}{2} ; \pi\right)$ : negatív kapcsolat (out-of-phase), y vezet

Azonban ahogy a korreláció nem jelent kauzalitást, úgy a wavelet koherencia sem ad ilyen jellegü információt. Ugyanakkor lehetőség van arra, hogy a parciális korrelációhoz hasonló mutatót alkossunk, ezzel közelebb kerülve a két folyamat közti valós összefüggés feltáráshoz. Továbbra is hangsúlyozandó azonban, hogy ok-okozati kapcsolatot ezzel nem tudunk identifikálni.

A parciális wavelet koherencia és a parciális fáziskülönbség fogalmait Aguiar-Conraira és Soares [2014] vezetik be. A parciális wavelet koherencia képlete $\tau$ időpontban, $s$ szélességű ablak mellett, az $M$ tagú változócsoport $i$. és $j$. elemei között:

\footnotetext{
${ }^{45}$ A szignifikancia teszteléséhez Aguiar-Conraira és Soares [2014] megoldását követem. Ennek során ARMA(1,1) modelleket illesztek a vizsgált idősorokra, majd Berkowitz és Kilian [2000] bootstrap módszerét használva képzek 1000 darab alternatív mintát (ez a mintaméret elegendő volt az eredmények stabilitásához, az outputok többszöri újrafuttatás után sem változtak). Ezekre egyenként kiszámolom a wavelet koherenciákat, így végül minden dátum/frekvencia párra egy empirikus eloszlást kapok. Adott pontban és $\alpha$ szignifikancia szint használata mellett akkor tekintem a wavelet koherenciát szignifikánsnak, ha az a generált minta felső $\alpha$ százalékába esik. A nullhipotézis szerint tehát minden vizsgált idősor $\operatorname{ARMA}(1,1)$ folyamatot követ.

${ }^{46}$ Ebből a képletből látszik, hogy amennyiben a használt wavelet függvény értéktartománya a valós számok halmazába esik, akkor az imaginárius rész azonosan nulla, és a fázis, illetve a fáziskülönbség nem vizsgálható. Ezért érdemes komplex wavelettel dolgozni.
} 


$$
r_{i j}(\tau, s)=\frac{\left|\operatorname{det}\left(\mu_{j}^{i}(\tau, s)\right)\right|}{\sqrt{\operatorname{det}\left(\mu_{i}^{i}(\tau, s)\right) \operatorname{det}\left(\mu_{j}^{j}(\tau, s)\right)}}
$$

Ahol $\operatorname{det}(\cdot)$ a determinánst jelöli, míg $\mu_{j}^{i}(\tau, s)$ az alábbi - a különböző idősorok kereszt wavelet transzformáltjainak simított verzióit tartalmazó - mátrix $j$. sorának és $i$. oszlopának elhagyásával áll elő:

$$
\mu(\tau, s)=\left[\begin{array}{cccc}
S\left(\left|W_{1}(\tau, s)\right|^{2}\right) & S\left(W_{21}^{*}(\tau, s)\right) & \cdots & S\left(W_{M 1}^{*}(\tau, s)\right) \\
S\left(W_{21}(\tau, s)\right) & S\left(\left|W_{2}(\tau, s)\right|^{2}\right) & \cdots & S\left(W_{M 2}^{*}(\tau, s)\right) \\
\vdots & \vdots & \ddots & \vdots \\
S\left(W_{M 1}(\tau, s)\right) & S\left(W_{M 2}(\tau, s)\right) & \cdots & S\left(\left|W_{M}(\tau, s)\right|^{2}\right)
\end{array}\right]
$$

Az ehhez tartozó parciális fáziskülönbség képlete pedig a következő:

$$
\phi_{i, j}(\tau, s)=\arctan \left(\frac{\Im\left(-\frac{(-1)^{i+j} \operatorname{det}\left(\mu_{j}^{i}(\tau, s)\right)}{\sqrt{\operatorname{det}\left(\mu_{i}^{i}(\tau, s)\right) \operatorname{det}\left(\mu_{j}^{j}(\tau, s)\right)}}\right)}{\Re\left(-\frac{(-1)^{i+j} \operatorname{det}\left(\mu_{j}^{i}(\tau, s)\right)}{\sqrt{\operatorname{det}\left(\mu_{i}^{i}(\tau, s)\right) \operatorname{det}\left(\mu_{j}^{j}(\tau, s)\right)}}\right)}\right)
$$

A mutatók értelmezése a korábbiakhoz hasonlóan történik.

\section{III.2.3. Egy szimulált példa}

A fenti mutatók használatát egy szimulált példán keresztül illusztrálom. A két generált idősor a következő módon áll elő:

$$
\begin{gathered}
x(t)=\sin \left(\frac{2 \pi}{24} \cdot t\right)+\sin \left(\frac{2 \pi}{60} \cdot t\right)+\varepsilon_{x}(t) \\
y(t)=\left\{\begin{array}{l}
\sin \left(\frac{2 \pi}{96} \cdot t\right)+\sin \left(\frac{2 \pi}{60} \cdot(t+12)\right)+\varepsilon_{y}(t), \text { ha } t \leq 240 \\
\sin \left(\frac{2 \pi}{96} \cdot t\right)+\sin \left(\frac{2 \pi}{24} \cdot t\right)+\varepsilon_{y}(t), \text { ha } 240<t \leq 360 \\
\sin \left(\frac{2 \pi}{96} \cdot t\right)+\sin \left(\frac{2 \pi}{60} \cdot(t-12)\right)+\varepsilon_{y}(t), \text { ha } t>360
\end{array}\right.
\end{gathered}
$$


Az egyenletekben $\mathrm{t}$ a hónapokat jelöli $(\mathrm{t}=1,2, \ldots, 540)$, így összesen egy $540 / 12=45$ évből (1970-2014) álló szimulációs mintával dolgozom. Az x(t) idősor egy 2 és egy 5 éves ciklusból tevődik össze, míg az y(t) végig rendelkezik egy 8 éves ciklust leíró komponenssel, illetve az első 240 és az utolsó 180 hónapban (1970-1989, 2000-2014) egy 5 éves, míg a köztes 120 hónapban (1990-1999) egy 2 éves ciklussal. $\varepsilon_{x}(\cdot)$ és $\varepsilon_{y}(\cdot)$ normális eloszlású hibatagok, 0 várható értékkel és 0,04 varianciával. Összegezve:

- $x(t)$ és $y(t)$ 1970M1-töl 1989M12-ig, illetve 2000M1-től 2014M12-ig az 5 éves frekvencia tartományban együtt és azonos irányba mozog, de míg a korai szakaszban y, addig a későbbiben már x vezetésével.

- A kettő között, 1990M1-től 1999M12-ig szintén van egy pozitív kapcsolat, de már a 2 éves tartományban, és nincs ,lead-lag” viszony a két változó között (teljesen szinkronban mozognak).

- $\mathrm{Az} y(\mathrm{t})$ idősornak a teljes mintán részét képezi egy 8 éves ciklus, miközben az $\mathrm{x}(\mathrm{t})$ idősornak nincs ilyen komponense.

A két változó időbeli lefutását a 20. ábra mutatja.

20. ábra: A generált változók időbeli lefutása

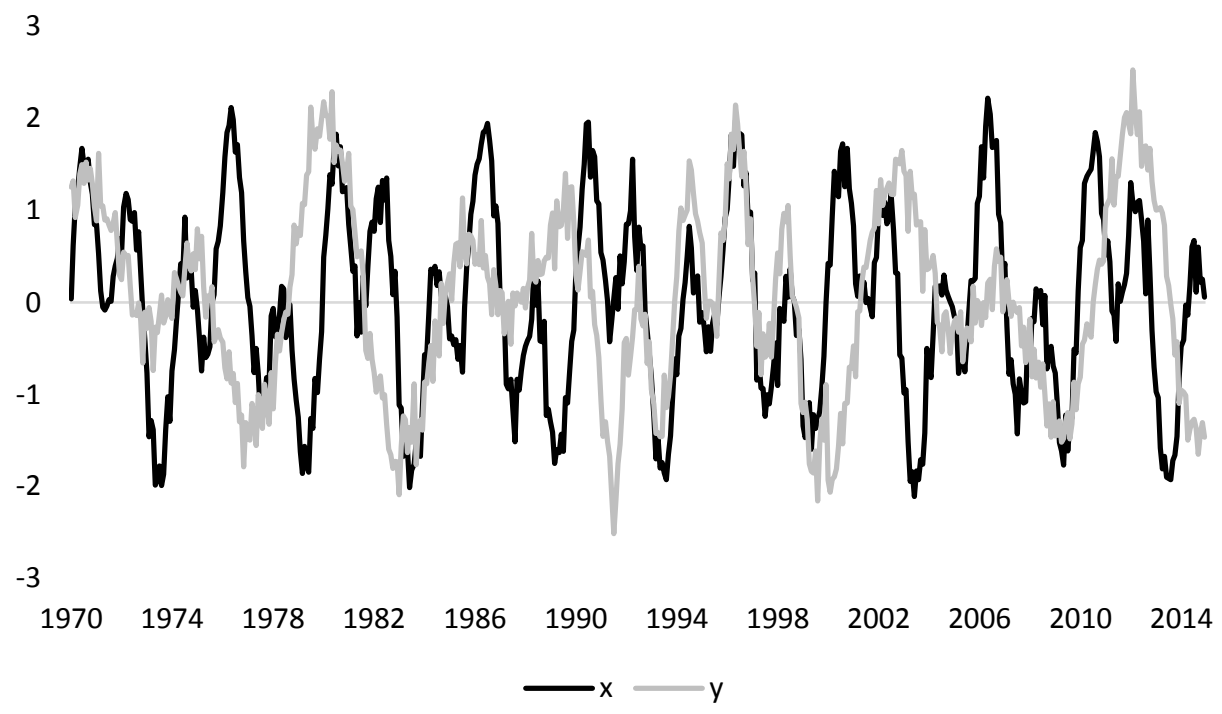

Forrás: saját szerkesztés.

A wavelet koherenciákat, azok szignifikanciáját, valamint a fáziskülönbségeket tartalmazza a 21. ábra. A felső panel hőtérképén a vízszintes tengely mutatja az időt (melyik év, melyik hónapjára számolódik a wavelet koherencia), a függőleges pedig a 
frekvenciát, években kifejezve (alacsony frekvenciától a magasig, azaz 8 éves ciklustól az 1 évesig). A vörös színek erősebb, a kékek gyengébb koherenciát jelentenek. Az 5\%os szint használata mellett szignifikánsnak tekinthető koherenciával jellemzett dátum/frekvencia párok halmazát fekete vonal határolja. Ez alól kivételt jelentenek a grafikon szélein található ívelt vonalak, melyek a végponti problémák által érintett területek elhatárolására szolgálnak. Az időszak elején a görbétől balra, a végén pedig attól jobbra található dátum/frekvencia párok esetén érdemes kellő fenntartással kezelni a kapott eredményeket. Látható, hogy az eljárás jól visszaadja a szimulált idősorok különböző frekvencia tartományokban történő együttmozgását, hiszen mind a 2, mind az 5 éves ciklusok a megfelelő időszakban jelennek meg az ábrán, és ezeken a dátum/frekvencia párokon kívül nincs más ,,szignifikáns terület”.

A két alsó panel a késleltetési struktúra feltárását segíti, ahol a könnyebb értelmezhetőség kedvéért a fáziskülönbségek az 1-3, illetve a 3-8 éves frekvencia tartományokon kiátlagolásra kerültek. Bár az ábrákon végig lehet követni a mutató alakulását, valójában csak a szignifikáns koherenciával jellemzett időszakokat érdemes vizsgálni. Ebből kitünik, hogy az 1990-es években a magas frekvencián (2 év) megfigyelt együttmozgás azonos irányú, de nincs egyértelmü vezetés/követés, a fáziskülönbség végig nulla, illetve ahhoz nagyon közeli értéket vesz fel, összhangban az x és az y változók képleteivel. Ezzel szemben az 1980-as évek végéig a 3-8 éves tartományban a $\left(-\frac{\pi}{2} ; 0\right)$, a 2000-es évek elejétől pedig a $\left(0 ;-\frac{\pi}{2}\right)$ intervallumba esik, azaz előbbinél y, utóbbinál x ,vezet”, és mindkét esetben pozitív a kapcsolat (in-phase), azaz itt is sikerült visszakapni a megfelelő összefüggést. Megjegyzendő továbbá, hogy y(t) hiába tartalmazott egy 8 éves ciklust, ez nem jelent meg az ábrákon, mivel x(t) már nem rendelkezett ilyen komponenssel. 
21. ábra: A generált változók wavelet koherenciája és fáziskülönbsége
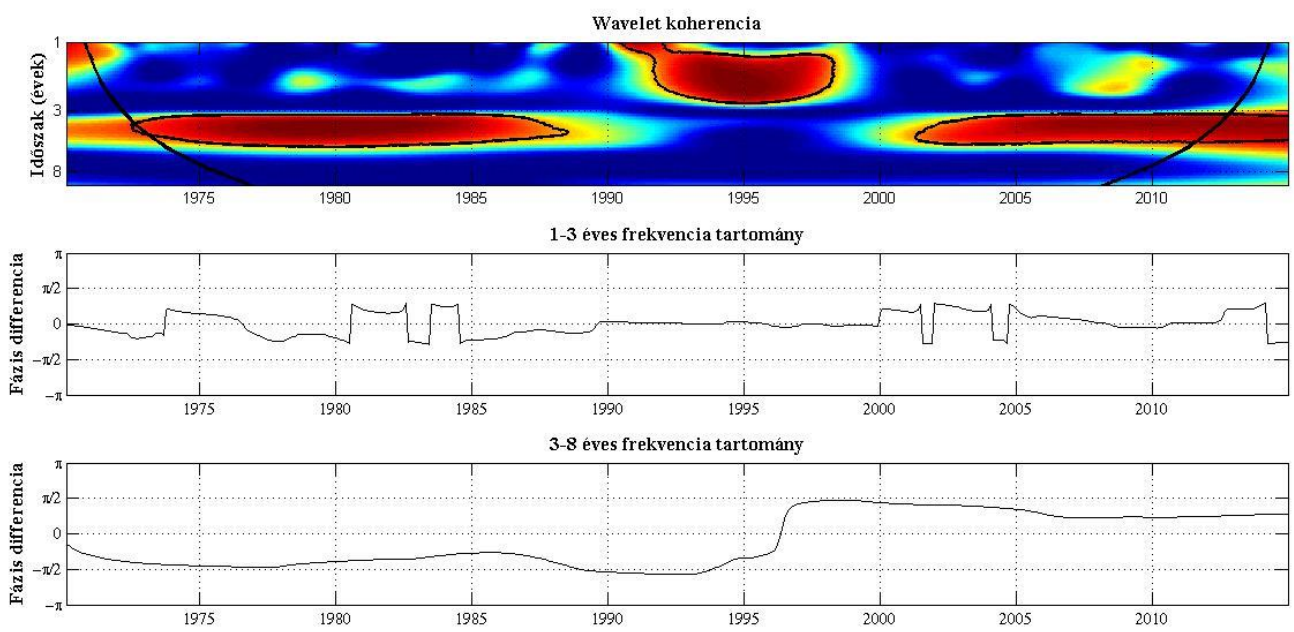

Forrás: saját szerkesztés.

A fenti ábra egyben arra is rámutat, miért preferálom a folytonos wavelet traszformáció (CWT) használatát a diszkrét (DWT) esettel szemben. Míg utóbbinál gondosan meg kell választani, hogy milyen idő/frekvencia beállítások mellett alakítsa át az algoritmus az eredeti adatsort, addig CWT-nél a hőtérképekről egyszerűen leolvasható és interpretálható az összefüggések szignifikanciája és időbeli változása, ezzel nagyban segítve a feltáró elemzést. Ennek természetesen ára van, mégpedig a nagyobb számítási kapacitásigény formájában.

\section{III.3. Adatok}

A felhasznált makrogazdasági idősorok a Federal Reserve Economic Database ${ }^{47}$ (FRED) és az $\mathrm{OECD}^{48}$ adatbázisaiból származnak. Előbbi az ipari termelés és a fogyasztói-árindex (CPI) havi százalékos növekedési ütemeinek, míg utóbbi a negyedéves (szintén százalékos) GDP növekedési ütemeknek a forrása mind a négy vizsgált ország (Németország, Norvégia, Oroszország és Svédország) esetén. Az ipari termelés kivételével minden idősor szezonálisan igazított formában érhető el, ezért az ipari adatsorból az EViews program segítségével, TRAMO/SEATS eljárással készült el a szezonálisan igazított verzió. Az olajár havi bontású idősora az északi-tengeri Brent olajtípus spot árainak (USD/hordó) havi átlagaként áll elő, és az Energy Information

\footnotetext{
${ }^{47}$ https://research.stlouisfed.org/fred2/

${ }^{48} \mathrm{http}$ ://stats.oecd.org/
} 
Administration (EIA) honlapjáról ${ }^{49}$ származik. Mivel csak 1987 májusától állnak rendelkezésre transzparens árak, ezért a korábbi évekre az Észak-Amerikában irányadó West Texas Intermediate (WTI) olajtípus (FRED honlapján fellelhető) havi (szintén USD/hordó) árai alapján készítettem becslést. Ennek során azzal a feltételezéssel éltem, hogy 1987 májusa előtt a WTI és Brent havi átlagárakban bekövetkezett hó/hó alapú százalékos növekmény megegyezik egymással. Az olajár idősorban nincs, vagy legalábbis nagyon gyenge a szezonális komponens ${ }^{50}$, ezért az további transzformáción nem esett át. A modellekbe a nominális, illetve az amerikai CPI-vel történő diszkontálás után előálló reál olajár havi és negyedéves százalékos növekedési ütemei kerülnek. Emellett még a Kilian-féle globális reál aktivitási index (Kilian [2009]) havi bontású idősora (és annak negyedévenkénti átlaga) is bekerül a modellbe, ami a nyersanyagok iránt jelentkező világpiaci kereslet hosszú távú trendtől való eltérését jelzi. A 3. táblázat az egyes változókhoz tartozó mintákat foglalja össze, a különbözö wavelet mutatók minden esetben a lehető leghosszabb időszakra (a két vagy három idősor közös részére) vonatkoznak majd.

3. táblázat: Az elemzéshez használt változók rendelkezésre állása (felbontás, idősor terjedelme, ország)

\begin{tabular}{lcc}
\hline & Havi & Negyedéves \\
\hline GDP & - & 1970Q1-2015Q2 \\
& & (kivéve RUS: 1995Q2-2015Q2) \\
\hline
\end{tabular}

1970M1-2015M2

Ipari termelés (kivéve RUS: 1993M2-

2015M3)

1970M1-2015M3

Infláció

(kivéve RUS: 1992M2-

2015M3)

\begin{tabular}{lll}
\hline Olajár (nominális) & 1970M1-2015M3 & - \\
\hline Olajár (reál) & $1970 \mathrm{M} 1-2015 \mathrm{M} 8$ & $1970 \mathrm{Q} 1-2015 \mathrm{Q} 2$ \\
\hline Reál aktivitási index & $1970 \mathrm{M} 1-2015 \mathrm{M} 1$ & $1970 \mathrm{Q} 1-2014 \mathrm{Q} 4$ \\
\hline
\end{tabular}

Forrás: saját szerkesztés.

\footnotetext{
${ }^{49} \mathrm{http} / / / \mathrm{www}$. eia.gov/petroleum/data.cfm

${ }^{50}$ A téli fütési, illetve a nyári vezetési szezon ugyan kimutatható mintázatot eredményez a keresletben, ugyanakkor az erőforrás tárolhatósága, valamint a finomítói karbantartások fogyasztáshoz való igazítása (a karbantartást a legkisebb kereslettel jellemezhető hónapokra időzítik) azzal a következménnyel jár, hogy az árban már nem lelhető fel ehhez hasonló szezonális faktor.
} 
A 4. táblázatban a tanulmány fókuszául szolgáló két ország, Svédország és Norvégia makrogazdasági idősorainak leíró statisztikáit találjuk. Ebből kitünik, hogy míg a mintaidőszak során az inflációs folyamatok kitüntetett pontjai mindkét országban hasonló nagyságrendủek voltak, addig a reálgazdasági változók esetében átlagosan gyorsabb norvég bővülési ütem és ezzel együtt magasabb szórás figyelhető meg.

4. táblázat: Svédország (SWE) és Norvégia (NOR) makrogazdasági mutatóinak leíró statisztikái

\begin{tabular}{lcccccc}
\hline & \multicolumn{2}{c}{ Ipari termelés } & \multicolumn{2}{c}{ CPI infláció } & \multicolumn{2}{c}{ GDP } \\
\hline SWE & NOR & SWE & NOR & SWE & NOR \\
\hline Átlag & $0,11 \%$ & $0,19 \%$ & $0,38 \%$ & $0,39 \%$ & $0,53 \%$ & $0,73 \%$ \\
\hline Szórás & $2,43 \%$ & $4,14 \%$ & $0,51 \%$ & $0,45 \%$ & $1,17 \%$ & $1,23 \%$ \\
\hline Relatív szórás & 21,2 & 21,9 & 1,3 & 1,2 & 2,2 & 1,7 \\
\hline Minimum & $-25,85 \%$ & $-39,10 \%$ & $-1,42 \%$ & $-1,35 \%$ & $-4,80 \%$ & $-2,60 \%$ \\
\hline Maximum & $25,37 \%$ & $34,23 \%$ & $2,89 \%$ & $4,97 \%$ & $3,80 \%$ & $4,00 \%$ \\
\hline & \multicolumn{3}{c}{ Forrás: saját szerkesztés. } \\
\end{tabular}

\section{III.4. Eredmények}

A svéd és norvég makrogazdasági változók olajárral való együttmozgását előbb egy sztenderd eljárással, a korreláció időbeli alakulásának ábrázolásával vizsgálom. E megközelítés célja kettős. Egyrészt némi betekintést nyújt az idősorok közti kapcsolat dinamikájába, másrészt viszonyítási alapként szolgál a wavelet transzformáción alapuló modellek outputjaihoz. A 22. ábrán hat különböző grafikont találunk, az első oszlopban a Svédországra, a másodikban a Norvégiára vonatkozó eredményekkel. Az első sorban a hó/hó alapú CPI infláció és a nominális olajár (szintén százalékban megadott) havi változása közti korreláció időbeli alakulása szerepel. A korreláció mindig 31 hónap adataiból számolódik, mégpedig úgy, hogy a vízszintes tengelyen szereplő dátum +/- 15 hónap jelenti a mintát. Hasonló elven áll elő az ipari termelés és a reál olajár havi (százalékos) változásai közti korreláció a táblázat második sorában, míg a legalsó részben a GDP és a reál olajár negyedéves változásaiból készült, minden esetben 31 (dátum +/15) negyedévnyi minta felhasználásával. Az ábrákon szürke oszlopdiagrammal kerülnek feltüntetésre a korrelációkhoz tartozó kétoldali t-próbák p-értékei. 
Az eredményekből kiderül, hogy mindkét országban a 2000-es években vált szignifikánssá a nominális olajár és az infláció közti - egyébként pozitív - korreláció, és Svédországban valamivel erősebbnek tűnik a változás. Ezt megelőzően legfeljebb egyegy rövid periódusban lehetett némi együttmozgást találni. Az ipari termelés és a reál olajár között már nehezebb bármiféle összefüggésre, illetve annak változására lelni, maximum Svédországban lehetett rövid ideig szignifikáns a kapcsolat. Érdekes ugyanakkor, hogy míg a '90-es évek első felében negatív, addig az ezredforduló és a globális pénzügyi válság táján pozitív korrelációról beszélhetünk. Ezzel szemben a GDP és a reál olajár kapcsolatában egyértelmü, de ellentétes irányú, tulajdonképp az előzetes várakozásoknak is ellentmondó dinamikák figyelhetők meg. Míg Svédországban a 2000es években szinte végig, addig Norvégiában legfeljebb az 1970-es években volt szignifikáns a két változó közti együttmozgás, a korreláció mindkét esetben a pozitív tartományokban mozgott. Utóbbinál lehet érvelni a létrehozott nyugdíjalap kiegyensúlyozó szerepével, ami az utolsó 20-25 évben képes volt az olajárban bekövetkező mozgásoktól függetleníteni a reálgazdasági változókat, ám Svédországban az intuíció alapján negatív, de folyamatosan gyengülő kapcsolatot kellene megfigyelnünk. Ugyanakkor a gazdasági növekedés szempontjából az olajár csupán egyetlen faktor a sok közül, így könnyen előfordulhat, hogy a kimutatott kapcsolat nem valós, és csak véletlen egybeesésről van szó, vagy ami még valószínűbb, a világgazdasági konjunktúra határozta meg mindkét tényező mozgását. Míg a válság előtti években az ázsiai gazdaságok fütötte globális növekedés élénkítette a svéd exporttermékek iránti keresletet, addig a pénzügyi lefagyás visszavetette az ezek iránt jelentkező igényt. Ez is arra utal, hogy érdemes a sima korrelációs elemzésnél mélyebbre ásni, és részletesebben vizsgálni a változók együttmozgását. 
22. ábra: Korrelációs mutatók időbeli alakulása és a kétoldali t-próbához tartozó pértékek
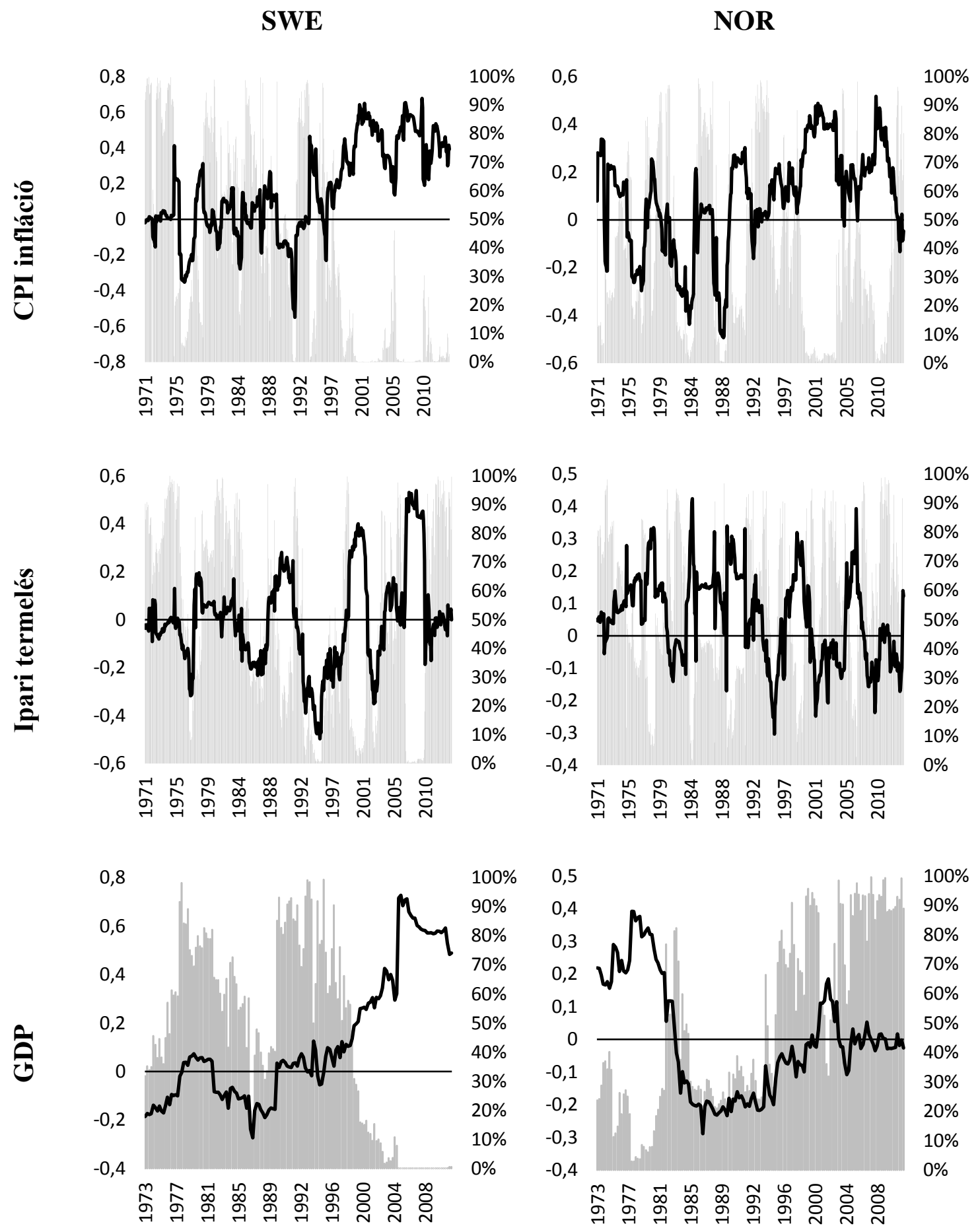

Forrás: itt és a 23-32. ábráknál is saját számítás.

Megjegyzés: Fekete vonal jelöli a korrelációt (bal tengely), szürke oszlop a p-értéket (jobb tengely). A korrelációk számítási módja a törzsszövegben található. 
A 23. ábrán a svéd és norvég, valamint a svéd és német CPI infláció, ipari termelés (mindkettő $M o M)$, illetve GDP-növekedés $(Q o Q)$ közti wavelet koherenciák láthatók. A vörös színek ezúttal is erős, míg a kékek gyenge koherenciát jelölnek a vizsgált országok sor szerinti makromutatói között.

Jól látható, hogy a svéd és a norvég gazdaság között 1980 környékén szignifikáns és bár az ábráról ez közvetlenül nem olvasható le - pozitív együttmozgás volt megfigyelhető a 3-8 éves (infláció esetén inkább a 2,5-3,5 éves) frekvencia tartományban. Ez később eltünt, és a válság körüli éveket leszámítva csak átmeneti jelleggel alakult ki szignifikáns koherencia. A két skandináv állam makromutatói tehát kevéssé mozognak együtt, függetlenül attól, hogy milyen frekvencián vizsgálódunk. Eközben Svédország európai integrációja miatt gazdasága egyre inkább az eurózóna magországainak ciklusait követi. A 23. ábráról egyértelmüen leolvasható, hogy a német és a svéd GDP, valamint ipari termelés az alacsonyabb frekvenciákon (3-8 év) már az 1990-es években egyre szorosabb kapcsolatot mutatott, ami a 2000-es években további frekvencia tartományokra terjedt ki. A CPI infláció esetén is konvergencia figyelhető meg, igaz, itt csak a pénzügyi válság éveiben. Összességében azt mutatják az eredmények, hogy a svéd gazdasági ciklusok mára szinkronba kerültek a némettel, föleg az alacsonyabb frekvenciákon, míg a norvéggal való együttmozgás az 1980-as évek óta jórészt kimutathatatlan, csupán a 2000es években erősödött némileg vissza. Kérdés, hogy Norvégia hogyan tudja magát ilyen szinten függetleníteni az európai folyamatoktól. Erre potenciális magyarázatként szolgálhat a bőséges olaj és földgázvagyon jelenléte, illetve annak következetes felhasználása a gazdasági ciklusok kisimítására. Ennek tesztelésére az olajár és a makromutatók együttmozgását fogom megvizsgálni. 
23. ábra: Svéd-norvég, illetve svéd-német wavelet koherenciák alakulása a makrogazdasági változók (CPI, ipari termelés, GDP) viszonylatában
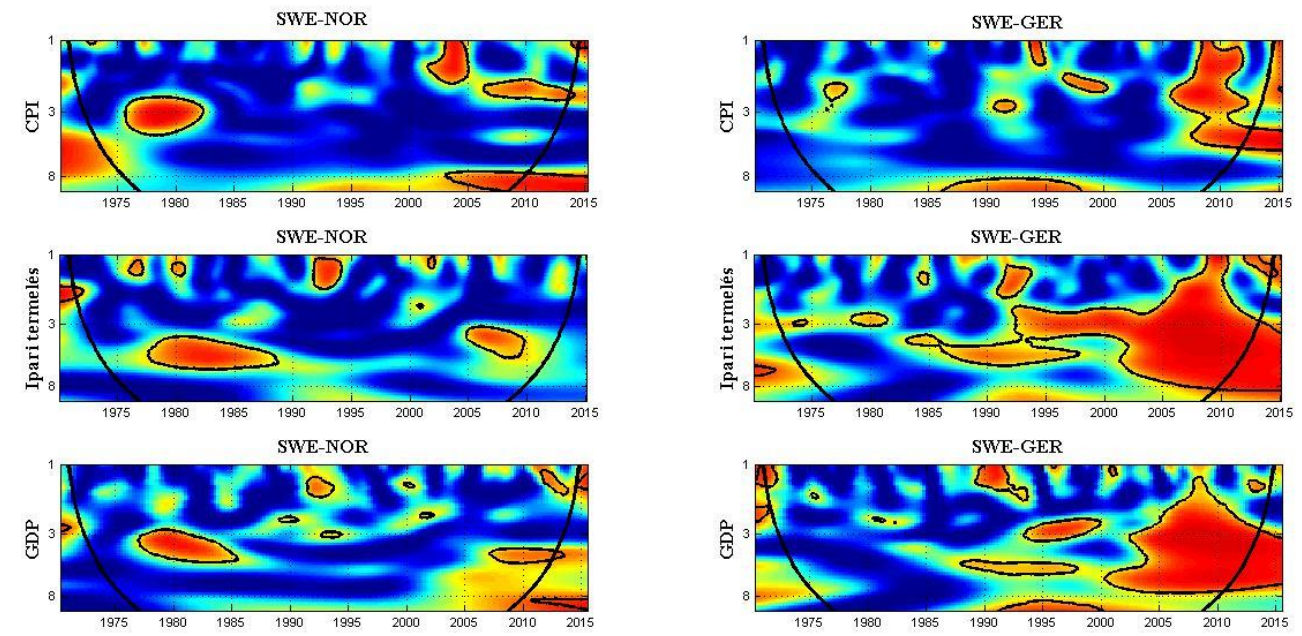

\section{III.4.1. Infláció}

A nominális olajár és CPI infláció közti wavelet koherenciát, valamint az ehhez tartozó fáziskülönbségeket mutatja a 24. ábra ${ }^{51}$. Az 1990-es évek kezdetéig Svédországban jellemzően az üzleti ciklusok (3-8 év) szintjén találunk szignifikáns koherenciát, és a negatív, de - $\pi / 2$-nél nagyobb fáziskülönbségekből az is kiderül, hogy a nominális olajár változása megelőzte a CPI inflációét, azaz a nyersanyag árának az üzleti ciklusok tartományában bekövetkező emelkedését a pénzromlási ütem gyorsulása követte. Ezután egészen a 2000-es évek első feléig nincs kimutatható kapcsolat a két változó alakulása között, ám 2005-től ismét szignifikánssá válik a koherencia, ezúttal azonban a magasabb (1-3 éves) frekvencia tartományban. Itt is igaz, hogy a változók azonos irányba mozognak, mégpedig az olajár vezetésével. A 21. ábrán bemutatott korrelációs elemzést tehát ki lehet egészíteni azzal, hogy a 2000-es években tapasztalt szinkronizáció a magas (1-3 éves) frekvencia tartományokban való összekapcsolódásnak köszönhető, és már jóval korábban is volt kapcsolat a két változó között, amit azonban az idősoros megközelítés aggregáló jellege elrejtett.

Norvégia esetén az 1970-es években a svédországinál valamivel szélesebb frekvenciasávban figyelhető meg szignifikáns wavelet koherencia, ugyanakkor ez hamar

\footnotetext{
${ }^{51}$ A korábbi jelölésekkel: az olajár mindig az y(t), míg a makrogazdasági változó az x(t) idősornak felel meg.
} 
megszünik, szomszédjával ellentétben nem tart ki a '90-es évek elejéig. Bár az ezredfordulót követően újra felerősödik a kapcsolat, a változók együttmozgása már kevésbé kiterjedt. Összességében megállapítható, hogy a két országban az inflációs folyamatok és az olajár alakulása között időben sokat változott a koherencia nagysága és szignifikanciája, Norvégia esetén pedig megközelítőleg a '80-as évek elejétől kezdve a svédországinál lazább volt a változók kapcsolata.

24. ábra: A havi CPI infláció és a nominális olajár havi százalékos változásai közti wavelet koherenciák és fáziskülönbségek alakulása Svédország, illetve Norvégia esetében
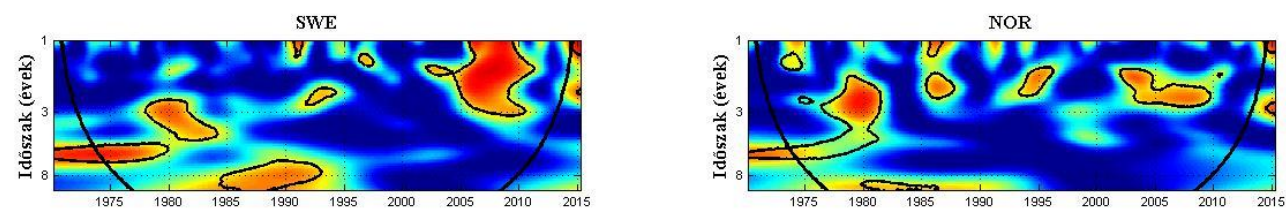

1-3 éves frekvencia tartomány

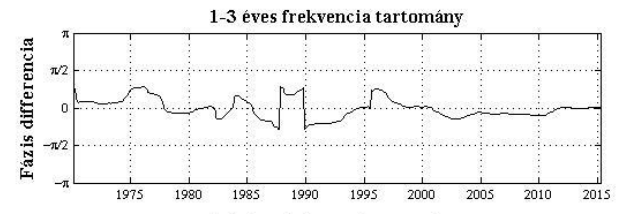

1-3 éves frekvencia tartomány

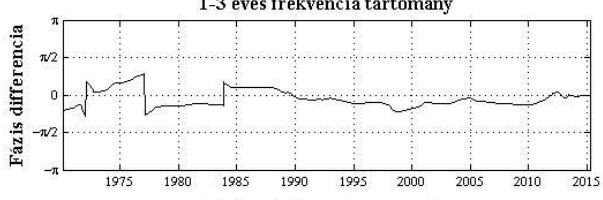

3-8 éves frekvencia tartomán
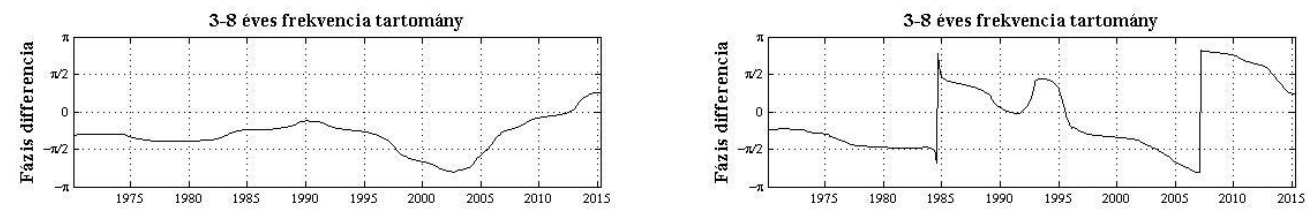

\section{III.4.2. Ipari termelés}

A kapcsolódó irodalom központi témái az 1970-es évtized két olajár sokkja, az azokat követő stagflációs időszakok, illetve a recesszió elmaradása a 2000-es évek nagy áremelkedése során. Az inflációs mutatókból már kiolvasható volt az együttmozgás gyengülése, azonban a reálgazdasági változók esetén ez a folyamat sokkal erősebben jelentkezik. A 25. ábrán a reál ipari termelés és a reál olajár havi változásai között fennálló wavelet koherenciák és fáziskülönbségek időbeli alakulása látható. Ezekből három fő megállapítás következik. Egyrészt a svéd ipari teljesítmény az 1970-es és 1980-as években a norvégnál hosszabb ideig és szélesebb frekvencia tartományban kapcsolódott az olajárhoz (amit a 22. ábrán szereplő korrelációs megközelítés egyáltalán nem tudott visszaadni). Másrészt mindkét országban utóbbi követte az otputot, ami összhangban van Kilian [2009] hipotézisével, mely szerint az elmúlt évtizedekben leginkább az aggregált 
keresleti sokkok felfutása fütötte a nyersanyagárak emelkedését, azaz többnyire a gazdasági aktivitás változása okozza az olajár elmozdulását, nem pedig fordítva. Végezetül vegyük észre, hogy ezt követően Norvégiában már csak 1995 és 2005 között alakult ki szignifikáns koherencia, mégpedig az üzleti ciklusok tartományában, az olajár vezetésével. Úgy tünik tehát, hogy a norvég gazdaság - sok más termelővel szemben kellőképp függetleníteni tudta magát a reálár magas voltilitásától, és különösen a rövid távú kilengésekre maradt érzéketlen. Arról sem szabad azonban megfeledkezni, hogy a sima wavelet koherencia nem veszi figyelembe más változók - többek között a globális aktivitás - hatásait. Ezért a 25. ábrán látható eredmények robusztusságát parciális mutatókkal, a Kilian [2009] által képzett aktivitási index beemelésével vizsgálom, ezzel kiszürve az olajár változásából azokat a részeket, amelyeket a nyersanyagok iránti aggregált kereslet alakulása magyaráz.

25. ábra: A reál ipari termelés és a reál olajár havi százalékos változásai közti wavelet koherenciák és fáziskülönbségek alakulása Svédország, illetve Norvégia esetében
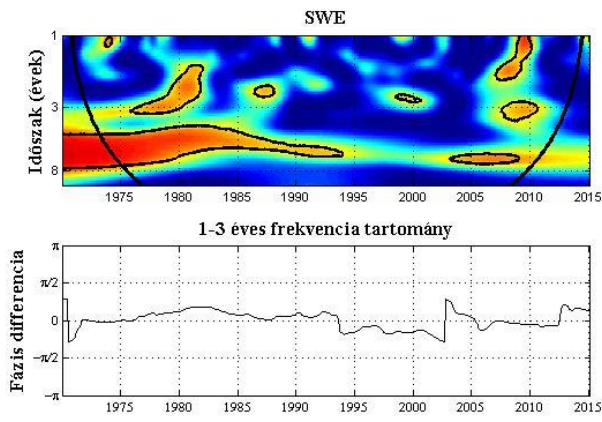

3-8 éves frekvencia tartomány

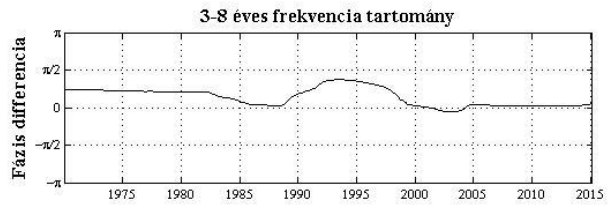

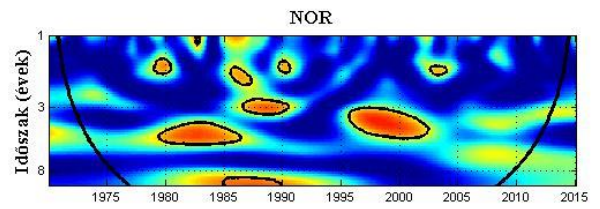

1-3 éves frekvencia tartomány

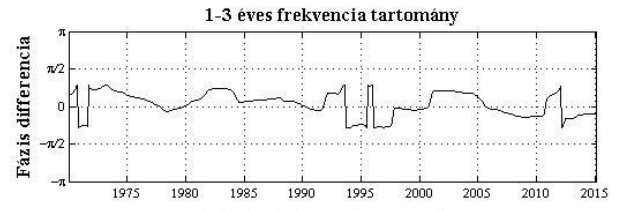

3-8 éves frekvencia tartomány

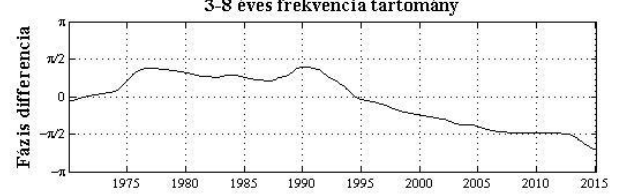

A 26. ábra szerint a nyersanyagpiaci folyamatok kiszürése után az olajár már kevésbé van szinkronban a svéd ipari termeléssel. Az üzleti ciklusok szintjén 1975 és 1985 között jelentkezik szignifikáns wavelet koherencia, míg magasabb (1-3 éves) frekvencián a '70es és '80-as évek fordulóján. Előbbinél végig az ipar vezet, ám utóbbinál rövid ideig előfordul, hogy olajár lead mellett ellentétes irányba mozognak a változók, azaz alacsony frekvenciákon a makrogazdasági folyamatok magyarázhatják az olajár alakulását, míg magas frekvenciákon az olajár növekedése - bizonyos esetekben - megelőzi a gazdasági 
teljesítmény visszaesését. Az is jól látható, hogy a globális aktivitás hatásainak kiszürésével az 1-3 éves sávból eltünt a pénzügyi válság idején korábban kimutatott szignifikáns koherencia. Ez megmagyarázza, hogy a 25. ábrán miért mozogtak azonos irányba az olajár vezetésével ezek a változók: mindkettőt a világgazdaság alakulása befolyásolta. Norvégia esetében is van némi eltérés a sima és a parciális eset között, de a fő következtetések nem változnak. Továbbra is inkább a 3-8 éves tartományban fordul elő szignifikáns koherencia, '90 előtt az ipar, utána az olajár vezetése mellett, ugyanakkor az eredmények a kapcsolat gyengeségét sugallják.

26. ábra: A reál ipari termelés és a reál olajár havi százalékos változásai közti parciális wavelet koherenciák és parciális fáziskülönbségek alakulása Svédország, illetve Norvégia esetében, a globális reál aktivitás kiszürése után
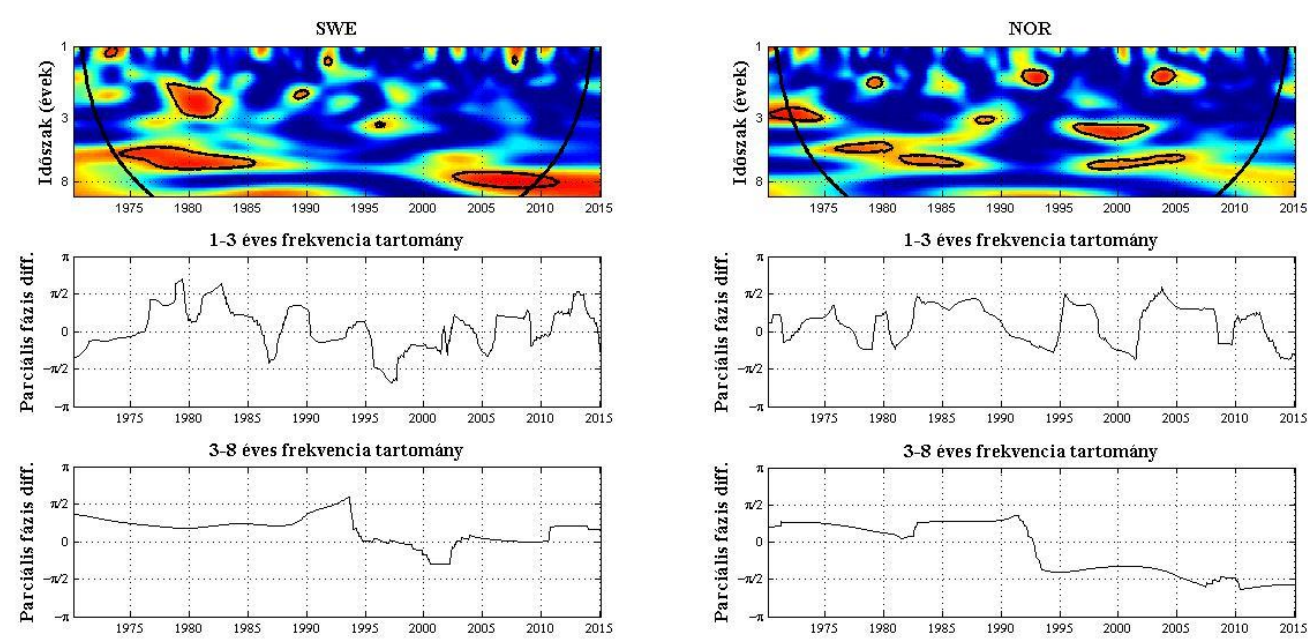

\section{III.4.3. GDP}

A GDP és a reál olajár mozgásának vizsgálata az ipari termelésnél kapott eredményhez hasonló konklúzióra vezet (27. ábra). Svédországban az üzleti ciklusok tartományában az 1990-es évek közepéig figyelhető meg szignifikancia, végig a reálgazdasági változó vezető szerepe mellett. Magasabb frekvenciákon csupán átmenetileg, 2005 és 2009 között mutatható ki kapcsolat, itt azonban nem lehet egyértelműen meghatározni a lead-lag struktúrát. Ezzel szemben a norvég GDP és a reál olajár rövid távú kilengései inkább a mintaidőszak első felében voltak szinkronban a bruttó hazai termék vezetése mellett, míg 1995 után ez a 3-8 éves sávba tolódott, mégpedig olajár leaddel. Ugyanakkor ezek mind átmeneti periódusok voltak, az ábráról inkább az olvasható le, hogy a wavelet koherencia 
az esetek túlnyomó többségében elhanyagolható maradt, megerősítve a norvég gazdaság olajártól való függetlenségét. Megjegyzendő továbbá, hogy a 22. ábrán bemutatott korrelációs elemzés - nyilván a +/- 15 negyedéves ablak miatt - az üzleti ciklusok sávjában történő együttmozgást nem tudta megfelelően lekövetni, míg a rövid távú kilengéseket jól jelezte (a svédeknél időben erősödő, a norvégoknál gyengülö kapcsolatot mutatott).

27. ábra: A reál GDP és a reál olajár negyedéves százalékos változásai közti wavelet koherenciák és fáziskülönbségek alakulása Svédország, illetve Norvégia esetében
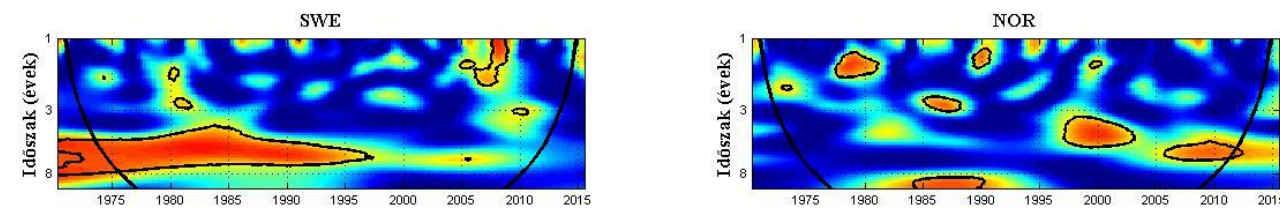

1-3 éves frekvencia tartomány

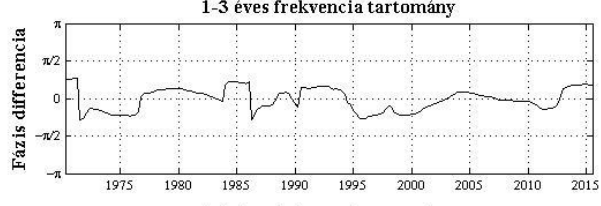

1-3 éves frekvencia tartomány

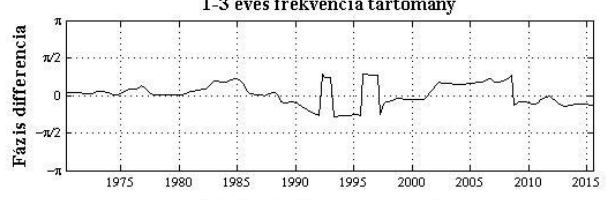

3-8 éves frekvencia tartomány
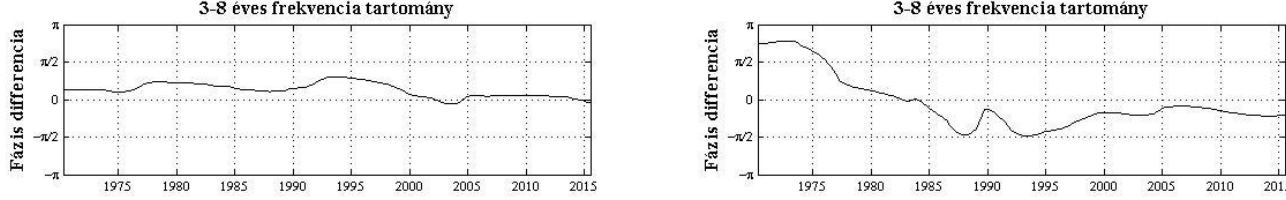

A globális aktivitás hatásának kiszürésével nyert parciális mutatók (28. ábra) Svédországnál szinte ugyanazt a mintázatot adják vissza, mint amit az ipari termelésnél is láttunk, bár itt még 1980 környékén sem figyelhető meg ellentétes irányú mozgás. Az legfeljebb átmenetileg, 1995 után és a 3 éves ciklusnál jelentkezik, az olajár vezetése mellett. Norvégia esetében alig marad szignifikáns koherenciával jellemezhető dátum/frekvencia pár a nyersanyagpiaci proxy kiszürése után. Amikor igen, akkor a kapcsolat pozitív, és legtöbbször az olajár leadel. Összességében megállapítható, hogy az elmúlt évtizedekben mindkét vizsgált gazdaságban inkább gyengült mintsem erősödött a reál olajár és a GDP mozgása közötti kapcsolat. 
28. ábra: A reál GDP és a reál olajár negyedéves százalékos változásai közti parciális wavelet koherenciák és parciális fáziskülönbségek alakulása Svédország, illetve Norvégia esetében, a globális reál aktivitás kiszürése után
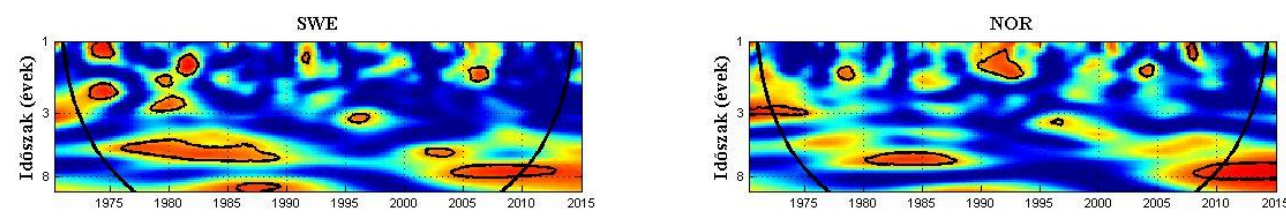

1-3 éves frekvencia tartomány
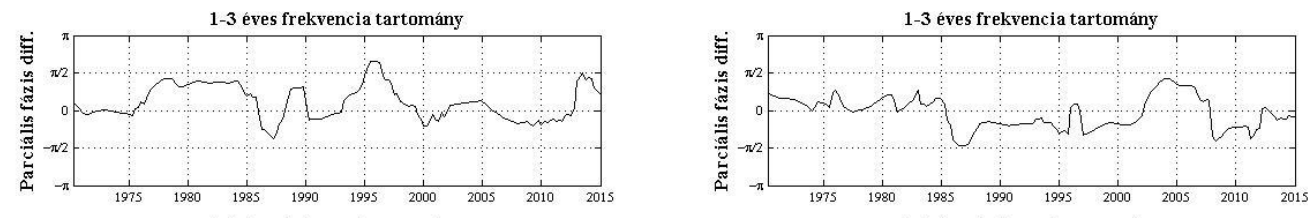

3-8 éves frekvencia tartomán
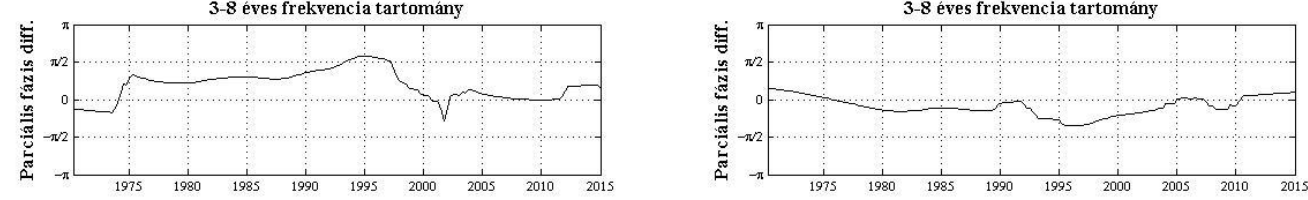

\section{III.4.4. Sokkok hatása}

Eddig csupán az olajár és a makrogazdasági változók együttmozgásának folytonos wavelet transzformációk révén történő vizsgálatára szorítkoztam, ok-okozati kapcsolatok feltárásához azonban ennél mélyebb elemzésre van szükség. Az irodalomban jellemzően az olaj árát érő sokkok makrogazdasági hatásainak vizsgálata kerül a figyelem középpontjába, ugyanakkor a II. fejezetben tárgyaltak tükrében a sokkváltozók identifikálása nem triviális probléma. A legegyszerübb megközelítés szerint ez közvetlenül az árból becsülhetö. A legtöbbet idézett módszerek az olajár feltételezett aszimmetrikus hatását is figyelembe veszik. Mork [1989] a nominális olajár százalékos változásának nullánál alulról cenzorált alakját használja, míg Lee et al. [1995] a reál olajár változására felírt GARCH(1,1) modellből indulnak ki, és az abból becsült volatilitással korrigálják a Mork féle megközelítést. Hamilton [2003] pedig a vizsgált negyedévre jellemző nominális olajárnak az utolsó 12 negyedév maximális árától vett eltérését használja, szintén nullánál alulról cenzorálva ${ }^{52}$. Az utóbbi években ugyanakkor megkérdőjeleződött mind az aszimmetrikus hatás hipotézisének, mind a múltbeli áradatokból kiinduló identifikációs stratégiának a helyessége (Kilian [2014]). Számos

\footnotetext{
${ }^{52}$ Utóbbi megoldás köszön vissza Aguiar-Conraira és Soares [2014] folytonos wavelet transzformációkra épülő kutatásában is, ahol egyik empirikus példájukban a föbb tőzsdeindexek olajár sokkokra való reakcióját vizsgálják.
} 
tanulmány arra a következtetésre jutott, hogy az olajárat érő sokkok nem egyformák, és a makrogazdasági hatások iránya és volumene függ az árváltozás forrásától (Kilian [2009], Bodenstein et al. [2012], Baumeister és Peersman [2013], Bjornland és Thorsrud [2014]). Az itt kapott eredményekből is az következik, hogy a változók közötti kapcsolat szorossága időben folyamatosan változott, amire egy lehetséges magyarázat lehet az áremelkedést/csökkenést kiváltó tényezők különbözősége, valamint azok makrogazdasági hatásainak változékonysága. Ezért Kilian [2009] II. fejezetben bemutatott modelljéből ismét előállítom a kínálati, az aggregált keresleti, valamint a specifikus keresleti sokkokat, ezúttal azonban az amerikai importolaj finomítói felvásárlási ára helyett a Brent típusra felírva az egyenleteket. Az eredményeket a 29-31. ábrák mutatják. Pozitív kínálati sokk alatt ezúttal is a termelés nem várt visszaesése értendő.

\section{$C P I$}

A svéd infláció a kínálati és az aggregált keresleti sokkokra nem, de a specifikusra viszonylag gyakran volt érzékeny (29. ábra). A legfrissebb adatok alapján azonban a 2005 után tapasztalt együttmozgás már eltünt, így jó eséllyel a 2014-ben induló, főleg negatív specifikus sokkok okozta olajár csökkenés nem okoz dezinflációs nyomást a svéd gazdaságban.

A norvég CPI is ellenállónak bizonyult. Bár a kínálati sokkoknál a '80-as években még az 1-3, illetve a 3-8 éves sávban is szignifikáns volt a wavelet koherencia, a 1990-es évek után már csak elvétve találni szignifikáns dátum/frekvencia párokat. Ezzel szemben az aggregált sokkok hatása a teljes mintán szinte kimutathatatlan, és a specifikus keresleti sokkoknál 2000-2010 között tapasztalt erősödés is csak átmeneti jelenségnek bizonyult.

A CPI infláció vizsgálatából tehát az derül ki, hogy:

- A különböző típusú sokkok hatása eltér egymástól.

- A sokkok hatása időben és frekvenciatérben is változik.

- Napjainkra mind a svéd, mind a norvég inflációra igaz, hogy kevéssé reagálnak az exogén sokkokra. 
29. ábra: A CPI havi százalékos változása és az olajpiaci sokkok közti wavelet koherenciák alakulása Svédország, illetve Norvégia esetében
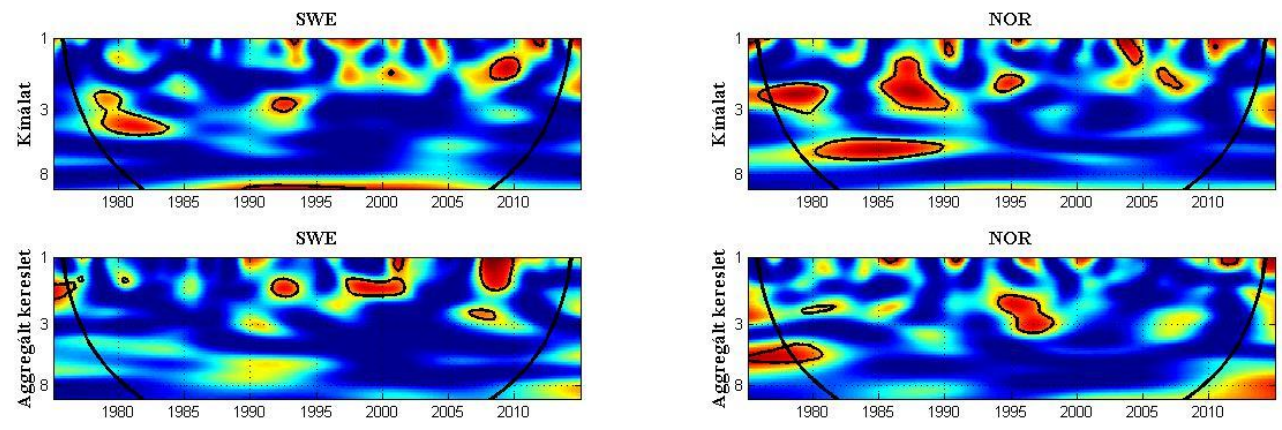

SWE
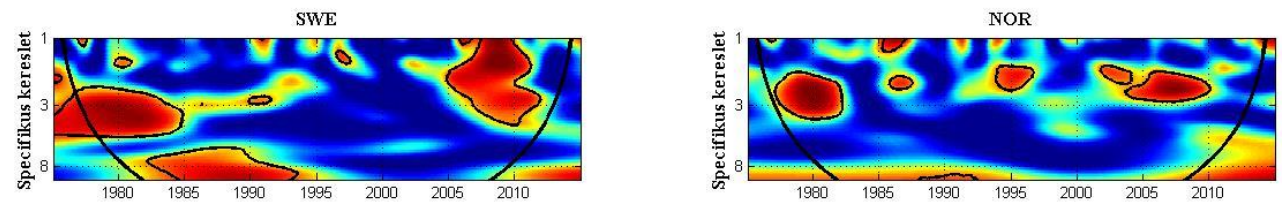

\section{Ipari termelés és GDP}

Az ipari termelésre és a GDP-re vonatkozó eredmények (30-31. ábra) nagyon hasonlóak egymáshoz. Svédországban a kezdeti kapcsolat - ha volt egyáltalán ilyen - mindhárom sokknál gyorsan eltünt, és legfeljebb átmenetileg tért vissza a 2000-es években. A szignifikáns koherenciával jellemzett területek föleg a magas frekvenciákon (1-3 év) jelentkeztek.

Norvégiában a sokkok és a makrogazdasági változók együttmozgása historikusan egy hajszálnyival erősebbnek tünik, mint a svéd esetben, miközben az olajár elemzésekor ennek a fordítottja volt igaz. Ez ismét rámutat annak fontosságára, hogy az árváltozás helyett érdemes a mögöttes faktorok vizsgálatára fókuszálni. Ami a konkrét eredményeket illeti, az aggregált sokkokkal fennálló koherencia ritkán volt szignifikáns, míg a specifikusnál a '90-es évek második felétől, a 3-8 éves sávban mutatható ki kapcsolat. A kínálati sokkokkal való együttmozgás meglehetősen érdekes struktúrát mutat, és a II. fejezethez hasonlóan ismét arra utal, hogy további dezaggregációra lehet szükség. Az 1990 utáni, szignifikáns koherenciával jellemzett dátum/frekvencia párok halmazára igaz, hogy a változók közti együttmozgás az olajár vezetése mellett azonos irányba történik (in-phase), mégpedig az 1-3 éves frekvencia tartományban. Ezt megelőzően azonban negatív (out-of-phase) kapcsolat állt fenn a 3-8 éves sávban, szintén az olajár vezetése mellett. Ennek lehetséges magyarázata, hogy épp az 1980-as években 
futott fel az OPEC-en kívüli olajtermelés, részben Norvégia vezetésével. Azaz ekkor a globális kínálat nem várt növekedésének egy meghatározó hányada közvetlenül Norvégiából származott, ami segítette a skandináv állam ipari termelésének és bruttó hazai termékének bővülését. Ez pozitív kapcsolatot jelent a két változó között, ugyanakkor az elemzés során a pozitív előjelü sokk a kínálat csökkenését jelöli, ezért került a fáziskülönbség a $\left(\frac{\pi}{2} ; \pi\right)$ intervallumba, ami ellentétes irányú mozgást takar. Nem mindegy tehát, hogy a kínálati sokk az adott országban vagy azon kívül következik be, ahogy azt már az Egyesült Államok munkanélküliségi rátájának példáján is láthattuk.

Összegezve a reálgazdasági változókra vonatkozó megállapításokat:

- A sokkok hatása eltér egymástól, ráadásul nagyságuk attól is függ, hogy az idő/frekvenciatér mely pontját vizsgáljuk.

- A svéd GDP és ipari termelés sokkokra való érzékenysége összességében kevésbé tünik „erősnek” (gyakorinak), mint a norvég mutatóké, ellentétben a reál olajár esetével.

- A kínálati elemzés rámutat, hogy a termelő országok esetében érdemes lenne a globális kínálat nem várt változását tovább bontani „hazai” és „külföldi” részre.

30. ábra: A reál ipari termelés havi százalékos változása és az olajpiaci sokkok közti wavelet koherenciák alakulása Svédország, illetve Norvégia esetében
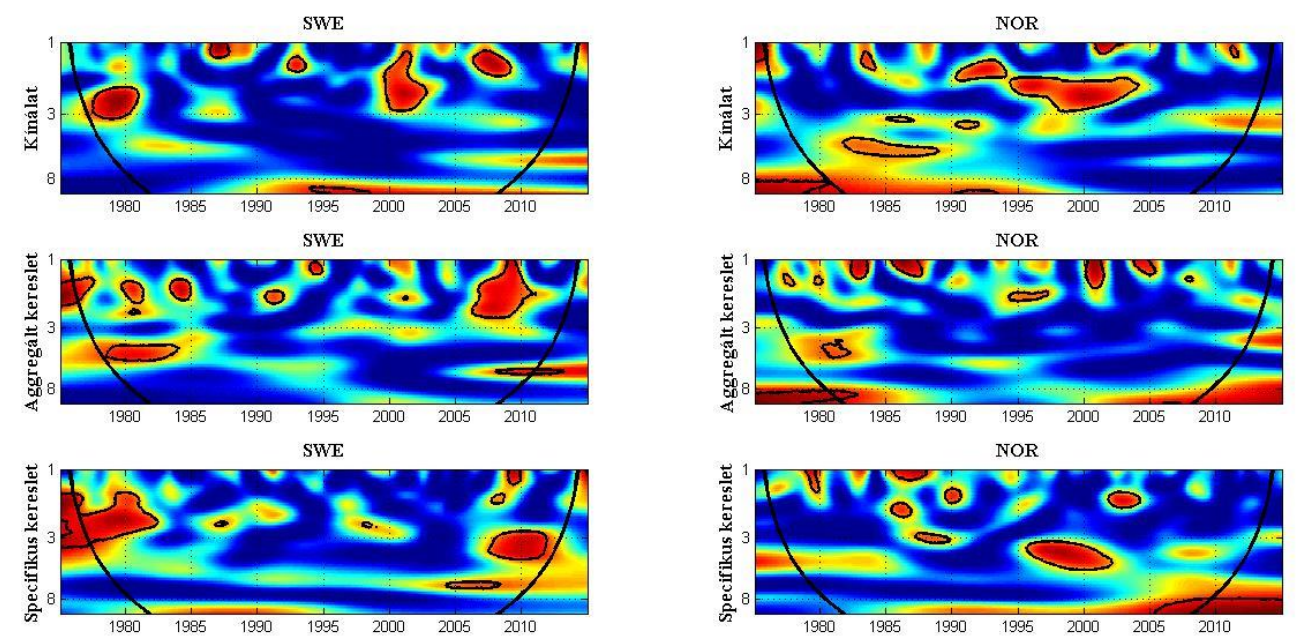
31. ábra: A reál GDP negyedéves százalékos változása és az olajpiaci sokkok közti wavelet koherenciák alakulása Svédország, illetve Norvégia esetében
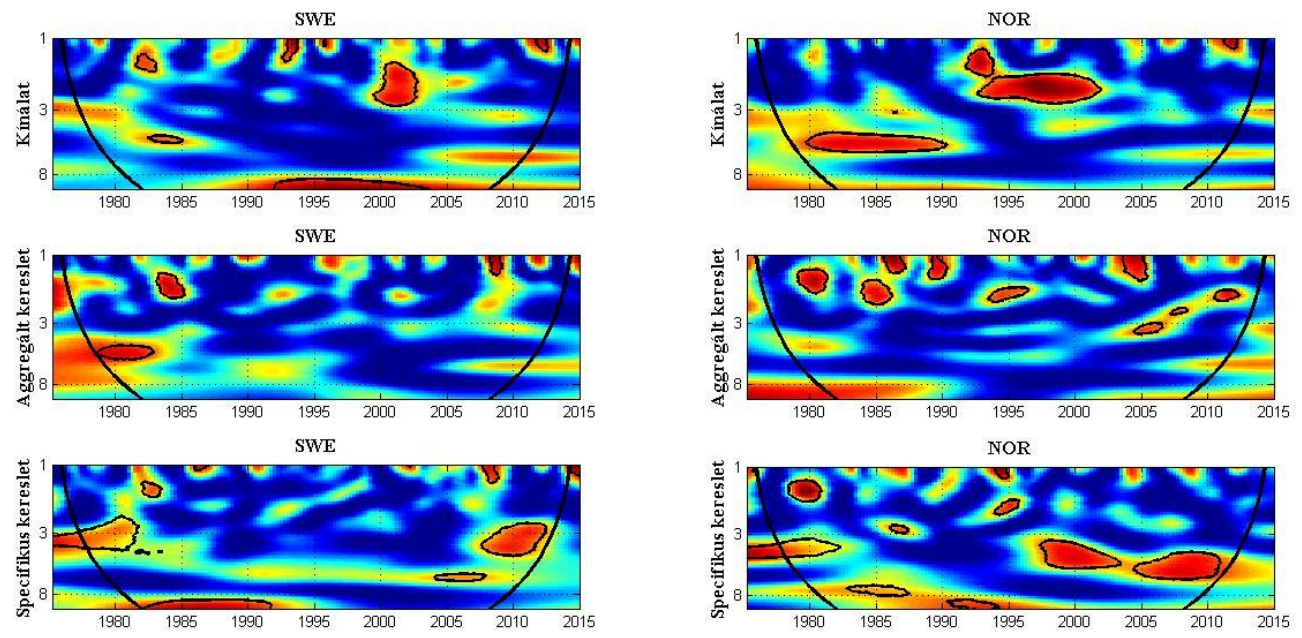

\section{III.4.5. Összegzés}

A fejezet elején feltett kutatási kérdésekre adott válaszok az alábbiak:

1. Gyakran előfordul, hogy a vizsgált makrogazdasági változók és az olajár közti kapcsolat ugyanabban az időpontban, de különböző frekvenciákon eltérő erősséggel és/vagy előjellel írható le, ami indokolja az elemzés frekvenciatérre történő kiterjesztését.

2. A kapcsolat nemcsak a frekvenciák mentén, hanem időben is jelentősen változik, ami akár a gazdaságok megváltozott ellenálló képességéből (Blanchard és Gali [2007]), akár az árváltozást kiváltó tényezők különbözőségéből (Kilian [2009]) is adódhat. Az olajár sokkokkal történő helyettesítése rámutat, hogy itt is mindkét tényező szerepet játszott: a különböző sokkok makrogazdasági hatásai eltérnek egymástól, és ezek a hatások az idő- és a frekvenciatérben egyaránt változnak.

3. A reálgazdasági változók tekintetében Svédországban inkább a kapcsolat gyengülése tapasztalható, míg Norvégiában nem lehet egyértelmű választ adni, úgy tünik, hogy a mintaidőszak során végig képesek voltak többé-kevésbé sikeresen függetleníteni gazdasági teljesítményüket az olajszektor jövedelmétől. Az inflációs folyamatok esetében mindkét országban az figyelhető meg, hogy előbb az üzleti ciklusok szintjén, majd a 2000-es években az 1-3 éves frekvencia tartományban mutattak szignifikáns kapcsolatot a nominális olajár változásával. 
4. Amennyiben kiszürjük az olajár változásának azon részét, amit a világgazdasági konjunktúra alakulása magyaráz, a maradék tag már jóval gyengébb koherenciát mutat a reálgazdasági mutatókkal. A mögöttes faktorok fontosságára mutat rá a sokkváltozókkal végzett elemzés is.

5. Az eredmények alapján tehát úgy tünik, hogy Norvégiában valamivel lazább a makrováltozók és az olajár kapcsolata, mint a nyersanyagot importáló Svédországban, bár a sokkokkal való együttmozgás a teljes mintaidőszakot tekintve már erősebb volt, legalábbis a reálgazdasági változók esetében. Ennek ellenére kijelenthető, hogy több exportőrrel szemben a norvég gazdaságot nem jellemzi az olajár volatilitásának (vagy az ezt kiváltó sokkoknak) való erős kitettség.

\section{III.5. Potenciális fejlesztési irányok}

Ígéretes iránynak tünik a kutatás kiterjesztése más országokra, főleg a norvég példa már többször említett egyedisége miatt. Ezt persze nehezíti, hogy a legtöbb nagy termelőről csak korlátozott terjedelemben és gyakran megkérdőjelezhető minőségben állnak rendelkezésre makrogazdasági adatsorok, mindenesetre néhány esetben már kellően hosszú idősorok is hozzáférhetőek. Ennek illusztrálására szolgál a 32. ábra, ahol az Oroszországra vonatkozó wavelet koherencia alakulása látható. A példa jól mutatja, hogy nem minden olajexportőrre jellemző a Norvégiánál tapasztalt rezisztencia, az orosz reálgazdasági változók pédául 2005 után egyre erősebben követték a reál Brent mozgását (utóbbit az itt meg nem jelenített fáziskülönbségekből lehet leolvasni). A GDP esetén ez az összefüggés egészen a mintaidőszak végéig kitart. 
32. ábra: A makrogazdasági változók és az olajár közti wavelet koherencia alakulása Oroszország esetében
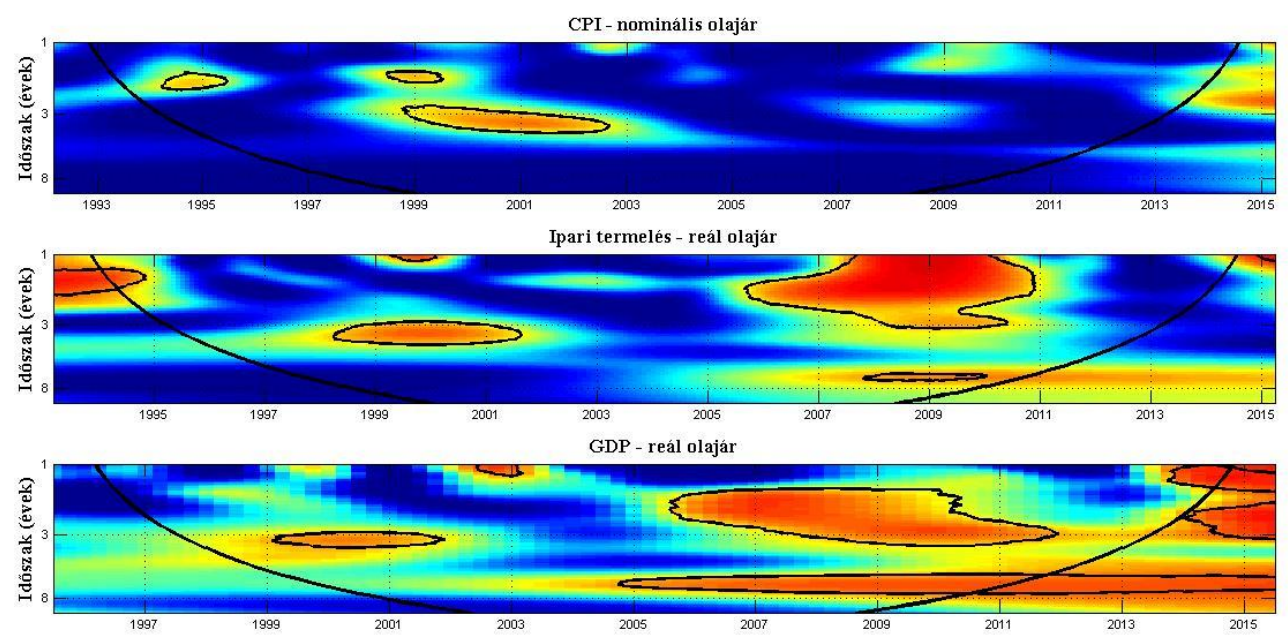

A fejezetben csupán a fontosabb makrogazdasági változók egy szük csoportjával dolgoztam, így a fejlesztési lehetőségek között kiemelt helyen szerepel a mutatók számának növelése. A foglalkoztatási, munkanélküliségi változók segítségével a munkaerő-piaci következmények feltárása válik lehetségessé, míg az ágazati bontású idősorok vizsgálata a gazdasági szektorok közti eltérés megismerésére alkalmas. Egy ilyen megközelítésben tesztelhető például, hogy a Mendoza és Vera [2010] által Venezuelára tett megállapítás (az olajár csökkenése kisebb visszaesést okoz az olajszektorban, mint azon kívül) érvényes-e más termelő országokra.

Ahogy a II. és III. fejezetekből kiderült, az olajár sokkok identifikálása nem triviális probléma, így érdekes kutatási irány lehet a különböző eljárások eredményeinek összehasonlítása, a fejezetben kifejtett megállapítások robusztusságának vizsgálata, különös tekintettel az aszimmetria potenciális jelenlétére.

A tanulmányban az együttmozgás különböző frekvenciákon érvényes erősségét, annak időbeli változását becsültem, ami az exogén sokkok esetében ugyan értelmezhető okokozati kapcsolat kimutatásaként, azonban továbbra sem alkalmas arra, hogy az árváltozás, esetleg a sokkok makrogazdasági hatásait számszerüsítsem vele. Ehhez minden bizonnyal a klasszikus idősoros technikák felhasználása szükséges. A folytonos wavelet transzformációk segítségével felderíthetők a változók közti kapcsolat 
szempontjából releváns frekvencia tartományok, melyek leszürésével (az eredeti idősor DWT-vel történő felbontásával) előállnak a regressziós elemzéshez szükséges adatok.

\section{III.6. A fejezet összefoglalása}

A folytonos wavelet transzformáció révén előálló wavelet koherencia és fáziskülönbség mutatók segítségével lehetővé válik a változók közti kapcsolat idő- és frekvenciatérben történő egyidejű elemzése. A fejezet során e kvantitatív eljárást arra használtam, hogy megvizsgáljam a Brent olajtípus árának a svéd és norvég makrogazdasági változókkal (CPI infláció, ipari termelés, GDP) való együttmozgását. A modellezési eredményekből kiderül, hogy a szokásos idősoros technikák mellé hasznos kiegészítést nyújt a frekvencia tartományokban végzett elemzés, új, az egyszerü korrelációs megközelítés által fel nem tárt összefüggések kinyerésére alkalmas. A konklúziók szerint az elmúlt évtizedekben Norvégia sikeresen tudta függetleníteni reálgazdasági teljesítményét az olajár kiszámíthatatlan ingadozásaitól, az idő/frekvencia párok túlnyomó többségében nem tapasztalható szignifikáns wavelet koherencia (különösen akkor nem, amikor kiszürjük a globális reál aktivitás torzító hatását). Ezzel szemben Svédországban szorosabb volt a változók kapcsolata, igaz, a parciális mutatók és a sokkok szintjén történő elemzés itt is arra utal, hogy ez jelentős részben a mögöttes faktoroknak köszönhető, ráadásul időben egyre kevésbé volt érzékelhető. 


\section{FEJEZET: Rövid távú olajár-előrejelzések teljesítményének stabilitása}

A kőolaj tőzsdei jegyzésében 2014-ben bekövetkezett trendszerű elmozdulás ismét a figyelem középpontjába helyezte a fosszilis energiahordozó piacát. Ennek megfelelően a médiában is egyre gyakrabban találkozunk a különböző bankok, elemzőházak, kereskedők által adott előrejelzésekkel, melyek a rövid (pár napos) és hosszú távú (akár több éves) változások ,jóslására” is vállalkoznak. Az előrejelzések sokszínúsége, illetve a pozitív/negatív kockázatok hosszú listája azonban jelzi, hogy a kivetítés nem triviális probléma, és nagy biztonsággal senki sem képes megmondani, mi várható a jövőben. Nem egyértelmü ugyanis, hogy a komplex adatgeneráló folyamat mellett egyáltalán megvalósítható-e az árak „kellően pontos” előrejelzése. Az eredmények ellentmondásosak, és sok függ attól, mennyire részletes idősorokkal dolgozunk. Hamilton [2009b] például kétségbe vonja a reál olajárak előrejelezhetőségét még havi vagy negyedéves szinten is. E hipotézist mások ugyan cáfolták (lásd Baumeister és Kilian [2013]), a rövid távú, napi bontású előrejelzéseknél a probléma ettől még fennállhat. Bár számos tanulmány született a napi spot árak elörejelzésének témakörében, ezek gyakran nem valós idejü projekciókat takarnak (lásd többek között Haidar és Kulkarni [2009], Shabri és Samsudin [2014], valamint Yu et al. [2008]), illetve jellemzően kevés modell összehasonlítását végzik el, így nehéz megállapítani, hogy a javasolt módszerek egymáshoz képest hogyan teljesítenek, valamint ez a teljesítménybeli különbség más időszakok során is fennáll-e. Ennek egyik oka alighanem a nagy mintákkal járó jelentős számítási kapacitásigény, ami szűkíti a kutatók lehetőségeit. Ezzel szemben havi vagy negyedéves adatok feldolgozása mellett már gyakoribb, hogy egyetlen tanulmányon belül akár több tucat modell eredményeit is összevetik (Alquist és Kilian [2010], Alquist et al. [2011]). Jelen fejezetben néhány napos előrejelzések esetén is elvégzem ezt a vizsgálatot, és az alkalmazott modellek meglehetősen széles körét tesztelem. Tudomásom szerint a fejezetben bemutatott valós idejü olajár-elörejelzéseket adó eljárásokat együtt még nem vizsgálták. A tesztelés során a következő kérdésekre keresem a választ:

1. Javít-e az elörejelzés pontosságán a határidős termékek vagy a különböző olajszármazékok árainak bevonása?

2. Mely modellek teljesítenek a legjobban a tényadatokra való illeszkedés és az árváltozás irányának előrejelzése szempontjából? 
3. Az előrejelzési horizont tekintetében mennyire stabilak az eredmények, azaz vannak-e olyan modellek, amelyek minden időhorizonton (egy-, két- és háromnapos előrejelzésnél is) a legjobban teljesítő eljárások közé tartoznak?

4. Előrejelzési időszak tekintetében mennyire stabil, azaz időben állandó marad-e a legjobb modellek halmaza, vagy folyamatosan változik?

5. Egyáltalán sikerül-e egy egyszerü benchmarknál számottevően pontosabb modellt építeni?

A kérdésfeltevésböl következik, hogy a kutatás során az induktív megközelítést alkalmazom, nincs elöre rögzített, tesztelhető elméletem a helyes válaszokkal kapcsolatban, a végső konklúziók csupán a modellek és időszakok azon szük halmazára vonatkoznak, melyeket az alkalmazás során áttekintek. Ezekből az egyedi megfigyelésekből általános érvényü összefüggések nem, csak sejtések szürhetők le.

A fejezet felépítése a következő. Előbb áttekintem a kapcsolódó szakirodalmat, ismertetem a dolgozatban használt eljárásokat és adatokat, majd megvizsgálom az egyes modellek teljesítőképességét. Végül összefoglalom a főbb tanulságokat, a potenciális továbblépési lehetőségeket.

\section{IV.1. A szakirodalom áttekintése}

Bashiri és Manso [2013] összefoglaló tanulmánya kvantitatív és kvalitatív kategóriákba sorolja az ismert eljárásokat, előbbit pedig tovább bontja ökonometriai, és általuk „nem standard" eljárásoknak nevezett csoportra, ami valójában a gépi tanulásos modelleket takarja. A kvantitatív modelleken belül jellemzően az ökonometriai eljárásokat használják, de az utóbbi időben gyorsuló ütemben terjednek a gépi tanuláson (machine learning) alapuló megközelítések, azon belül is az $\mathrm{SVM}^{53}$, illetve a neurális hálók (NN) alkalmazása. A következőkben Bashiri és Manso [2013] felosztásának megfelelően mutatom be az egyes eljárásokat és azok néhány alkalmazását.

\footnotetext{
${ }^{53}$ SVM: support vector machine. A továbbiakban is gyakran elö fog fordulni, hogy az eredeti angol elnevezést használom. Ezt sajnos elkerülhetetlenné teszi, hogy egyes kifejezéseknek nincs magyar megfelelője, illetve ha van, akkor sem terjedt el közgazdasági körökben. Az SVM például tartóvektor-gép lenne, de ezzel a kifejezéssel ritkán találkozunk.
} 


\section{IV.1.1. Ökonometriai modellek}

Az ökonometriai modellek csoportján belül két megközelítés lehetséges. Az első kizárólag az olajár múltbeli értékeiből jelez előre, más változókat egyáltalán nem használ. Ezek az egyváltozós idősormodellek mintázatot, szabályszerüséget keresnek a folyamat dinamikájában, a fundamentumokat figyelmen kívül hagyják. A másik megközelítés ezzel szemben a közgazdasági elméletet hívja segítségül, és a releváns árbefolyásoló tényezők felhasználásával próbál javítani az előrejelzés pontosságán.

\section{Egyváltozós idősorelemzés}

Az egyváltozós idősorelemzési modellekben egyetlen magyarázó változó, a függő változó késleltetett értékei szerepelnek. Az ARIMA-modell ${ }^{54}$ (Wang et al. [2004], Xie et al. [2006]) népszerüségét nemcsak az adja, hogy könnyen érthető és implementálható eljárásnak számít, hanem az is, hogy a belőle nyert elörejelzés számos esetben viszonyítási pontként szolgál a szofisztikáltabb eljárások számára (lásd például $Y u$ et al. [2008]). Gyakran találkozni olyan cikkel, ahol a szerzők valamilyen ARIMA projekcióhoz és/vagy a véletlen bolyongás feltevéshez ${ }^{55}$ viszonyítják saját eredményeiket. Alquist és Kilian [2010] például havi adatokkal dolgozva megmutatták, hogy a WTI olajtípusnál a futures árak rosszabb elörejelzői a jövőbeli spot áraknak, mint a véletlen bolyongás feltevése melletti kivetítés. Ennek lehetséges okaként a magas volatilitásból eredő kockázatot jelölik meg, ami beépül az árakba ${ }^{56}$.

\section{Pénzügyi modellek}

A pénzügyi modellek valójában továbbra is idősorelemzési megközelítéseket takarnak, az előbb bemutatott eljárásokhoz képest egy fő különbséggel, mégpedig a futures árak mint magyarázó változók bevonásával. Összességében elmondható, hogy a futures árak nem tekinthetők a jövőbeli spot árak torzítatlan elörejelzéseinek (Alquist és Kilian [2010], Yousefi et al. [2005]), sőt az sem teljesen egyértelmű, hogy használatuk javítja-e a

\footnotetext{
${ }^{54}$ ARIMA (autoregressive integrated moving average): autoregresszív integrált mozgóátlag-folyamat.

${ }^{55}$ Amikor a holnapi, holnaputáni stb. ár elörejelzése a legutolsó ismert értékkel egyenlő (eltolás nélküli véletlen bolyongás).

${ }^{56}$ A volatilitás modellezésére ARCH/GARCH típusú eljárásokat használnak (Kang et al. [2009]). Mivel sem ez, sem a szintén gyakran előkerülő hibakorrekciós eljárás (Lanza et al. [2005]) nem kapcsolódik szervesen a fejezet témájához, bővebb ismertetésüktől eltekintek.
} 
modellek előrejelző képességét, Alquist et al. [2011] legalábbis nem találtak erre utaló jelet $^{57}$.

\section{Strukturális modellek}

A strukturális modellek lényege, hogy a futures árak mellé/helyett újabb magyarázó változókat vonnak be. Ezek köre felhasználási területtől és az idősorok részletezettségétől (napi, havi, negyedéves) függ. Tang és Hammoudeh [2002] például egy „target zone” modellt használnak (Krugman [1991] módszerére építve), amelynek lényege, hogy bizonyos alsó és felső árküszöbök mellett az OPEC beavatkozik. Ennek oka, hogy túlságosan alacsony árak mellett a tagországok költségvetése nyomás alá kerül, míg magas árak esetén a szervezet befolyásán kívüli termelök a felhozatal növelésére, a vásárlók pedig a fogyasztás optimalizálására vannak ösztönözve. Konklúziójuk szerint a küszöbszintek közelében ez a modell valóban segíti az előrejelzést, de a köztes, illetve külső szakaszokon ez már nem mondható el ${ }^{58}$. Más szerzők (Merino és Ortiz [2005]; Ye et al. [2005], [2006]) a készleteket használták magyarázó változóként. E tanulmányok lényeges következtetése (összhangban Tang és Hammoudeh [2002] modelljével), hogy az áralakulás folyamata nem lineáris, egész más reakció figyelhető meg a készletek szintjétől függően. Ezen eredmények ismeretében az elemzés során én is kitérek különböző nemlineáris modellek használatára.

\section{IV.1.2. Gépi tanulás}

A számítási kapacitások rohamos növekedése következtében mára lehetővé vált a gépi tanulásnak (machine learning) nevezett modellek széleskörü használata. Ez a terület valahol a statisztika és a számítástudomány határmezsgyéjén található. Lényege, hogy nem egy konkrét, előre megadott függvényforma paramétereit becsli, hanem a modellező által specifikált tanuló algoritmus révén alakítja ki a végső függvényformát és kalibrálja

\footnotetext{
${ }^{57}$ Igaz, ők sem a napi adatokra fókuszáltak. Ellenben Haidar és Kulkarni [2009] úgy találták, hogy egy neurális háló előrejelző képességét már javítják a futures adatok (a WTI napi árára vonatkozóan). Erre a cikkre még visszatérek a gépi tanulásról szóló részben.

${ }^{58}$ Megjegyzendő, hogy az 1988-1999-es időszakot vizsgálták, amikor hivatalosan nem volt ilyen jellegü árzóna az OPEC-nél. A szerzők ugyanakkor megállapították, hogy a kartell viselkedése, konkrét döntései nem mondanak ellent az általuk alkalmazott elméletnek, azaz valószínüleg voltak olyan informális küszöbszintek, amelyek elérésekor emelkedett a közvetlen beavatkozás valószínüsége.
} 
annak paramétereit ${ }^{59}$. A gépi tanulás előbb a müszaki és természettudományos területeken jelent meg, mára azonban a társadalomtudományokban is elterjedt. Előnye, hogy a standard ökonometriában használatos, többnyire lineáris megközelítéseknél jóval komplexebb összefüggések leképezésére alkalmas. Ebben a formában azt mondhatjuk, hogy a gépi tanulás nem korlátozza a vizsgálati spektrumot egyetlen formulára, hanem számtalan lehetőség közül választja ki a legjobbat: nem a felhasználó, hanem az adatok döntenek. Ez az előny azonban a legnagyobb hátrány is egyben. Az ökonometriai eljárásokkal ellentétben a gépi tanulás ritkán alkalmas az ok-okozati kapcsolatok kimutatására (Statnikov et al. [2006]), és gyakori probléma a túlillesztés, amikor az adatokban mutatkozó zajra, egyedi mintákra tanul rá az algoritmus. Ennek következtében a gépi tanulás alkalmazásának legfontosabb - vagy legalábbis a kapcsolódó szakirodalomban mindig kiemelt helyen szereplő - eleme a túlillesztés elkerülése. Bár nincs univerzális, minden modellre és adathalmazra érvényes megoldás, számos lehetőség közül lehet választani. A téma feldolgozása meghaladná e tanulmány kereteit, ezért a későbbiekben csak azokat a módszereket fogom áttekinteni, melyeket az előrejelzés során is használok. Az olvasó a fontosabb eljárásokról átfogó leírást talál Berk [2008] és Vapnik [1995] (SVM), valamint Kriesel [2007] (neurális hálók) munkáiban.

A nyersolaj piaci árának előrejelzésére is mind gyakrabban használják e módszereket. Fernandez [2010] SVM és NN segítségével készített elörejelzést napi adatokon. Következtetése szerint rövid távon ezek nem teljesítenek jobban egy egyszerü ARIMAmodellnél, de hosszabb távon „legyőzik” azt. Alapvetően gyakori jelenség az irodalomban, hogy több modell összevetése során nem találnak olyan eljárást, amely minden időhorizonton jobbnak bizonyul a benchmarknál (lásd Baumeister és Kilian [2013]). Szintén érdemes figyelembe venni Haidar és Kulkarni [2009] eredményeit, akik a WTI napi spot árait modellezték (elörecsatolt) neurális hálók segítségével. Megállapításuk szerint az adatgeneráló folyamatban lévő nemlineáris függvényforma ${ }^{60}$ miatt a szokásos lineáris megközelítések alkalmatlanok az előrejelzésre, emellett az adatok megfelelő transzformációja, zajtól való előzetes szürése is fontos lépés, ugyanis

\footnotetext{
${ }^{59}$ E megfogalmazás kissé leegyszerüsítő, mert például neurális hálók esetén a függvényformát a modellező specifikálja, de az eljárás alapja épp az, hogy olyan struktúrát használ, amivel a függvények meglehetősen széles köre közelíthető. Így valójában az elemzö/programozó nem a változók közötti konkrét összefüggést adja meg parametrikus formában, csupán (közvetve) a szóba jöhető függvények halmazát, és a tanulás módját specifikálja.

${ }^{60}$ A nemlinearitás formális tesztelésére azonban nem tér ki a tanulmány, azt Haidar és Wolff [2011] igazolja.
} 
ezzel lehet elkerülni a túlillesztés (a zajra való rátanulás) csapdáját ${ }^{61}$. További következtetésük, hogy a piaci információk gyorsan beépülnek a futures árakba, így azok változása felhasználható az egy-, két- és háromnapos spot ár előrejelzésekben.

A gépi tanuláson alapuló módszerrel alkalmanként rendkívül magas, akár 80 százalék feletti arányban is sikerült eltalálni a néhány napos változások irányát (Haidar és Kulkarni [2009], Yu et al. [2008]), ám ezek az eredmények erős fenntartással kezelendők. Yu et al. [2008] például egy többlépcsős eljárással modellezik a Brent és WTI olajárak napi bontású idősorait. Az első lépcsőben EMD-módszerrel ${ }^{62}$ bontják fel az ár idősorokat különböző komponensekre, majd ezekre egyenként végeznek elörejelzést elörecsatolt neurális hálók (feed-forward neural network) segítségével, végül az egyes komponensekre kapott előrejelzésekből egy adaptív lineáris neurális hálóval (adaptive linear neural network) becsülik meg az ár idősorának alakulását. A megközelítés hátránya, hogy az eredmények nem adják vissza, milyen lenne a modell teljesítménye valós időben. Egyrészt az EMD-eljárás végponti problémákkal küzd (lásd Ma et al. [2013]), így a szerzők által (1986. január 1-jétől 2006. szeptember 30-ig) elvégzett EMDfelbontás belső pontjai nem feltétlenül esnek egybe azzal az eredménnyel, mint amit valós idejü feldolgozás esetén kaptak volna. Másrészt az algoritmus maga dönti el, hány komponensre osztja az idősort, tehát akár az is lehetséges, hogy a WTI-re kapott 11 komponens egy korábbi időpontban nem is állt volna elő (például 10 vagy 12 lett volna belöle).

Ahogy az említett példa is mutatja, komoly nehézségekbe ütközik az egyes modellek kizárólag az irodalomra hagyatkozó - rangsorolása, mivel különböző időszakokra, eltérő olajfajtákra és alkalmanként össze nem vethető módszerekkel állították elő őket. Yu et al. [2008] cikkének eredményeit például nem lehet összehasonlítani egy olyan modellével, ahol minden pontban kizárólag az akkor már rendelkezésre álló adatokat használták fel. További probléma, hogy a modelleket általában egy egyszerü benchmarkhoz (véletlen bolyongás, ARIMA) viszonyítják, így nem derül ki, hogy a mások által elért eredményekhez képest miként teljesít az új módszer. A később ismertetendő empirikus

\footnotetext{
${ }^{61}$ Shabri és Samsudin [2014] is azt találják, hogy megfelelő szüréssel javítható az előrejelzés pontossága. Ök ugyanakkor nem kifejezetten a zaj szürésére fókuszálnak, hanem wavelet-transzformáció segítségével bontják elemekre az olajár historikus idősorát, majd egy szelekciós eljárással eltávolítják az idősor azon részeit, melyek együttmozgása az eredeti idősorral nem elég erős. Az így nyert idősorokat egy neurális háló input adataiként használják.

${ }^{62}$ EMD (empirical mode decomposition): empirikus dekompozíció.
} 
eredmények tükrében úgy tünik, hogy a gyakorlatban egy-, két és háromnapos távlatban az 55-60 százalékos találati arány már igencsak kedvezőnek tekinthető. Feltéve persze, hogy nem egyszeri kiugrásról, hanem tartósan ebbe a sávba eső teljesítményről van szó.

\section{IV.2. Módszertan}

A fejezetben alkalmazott módszerek három csoportba sorolhatók:

- benchmarkként szolgáló heurisztikus;

- ökonometriai;

- gépi tanuláson alapuló modellek.

A konkrét eljárásokat, azok típusát, az előrejelzés tárgyát (ár/irány), a paraméterek frissítésének gyakoriságát és a modellek részletes bemutatásának irodalmát az 5. táblázat foglalja össze. A módszertani leírást a következő alfejezetek tartalmazzák.

5. táblázat: Az előrejelzés során használt modellek összefoglaló táblázata

\begin{tabular}{|c|c|c|c|c|}
\hline Módszertan neve & Típus & Elörejelzés & Frissítés & Hivatkozás \\
\hline Véletlen bolyongás & heurisztikus & ár, irány & naponta & - \\
\hline ARIMA & ökonometriai & ár, irány & évente/naponta & Hamilton [1994] \\
\hline ARX & ök & ár, irány & naponta & $\begin{array}{c}\text { Wang, Jain } \\
{[2003]}\end{array}$ \\
\hline LPM $^{\mathbf{6 4} / l o g i t}$ & ökonometriai & irány & naponta & $\begin{array}{c}\text { Wooldridge } \\
{[2012]}\end{array}$ \\
\hline Neurális háló & gépi tanulás & ár, irány & évente & Kriesel [2007] \\
\hline SVM & gépi tanulás & irány & évente & $\begin{array}{c}\text { Cristianini et al. } \\
{[2000]}\end{array}$ \\
\hline
\end{tabular}

Forrás: saját szerkesztés.

\section{IV.2.1. Heurisztikus modellek - Véletlen bolyongás}

A modell feltevése szerint a spot olajárak alakulása rövid távon eltolás nélküli véletlen bolyongást követ, így a holnapi, holnaputáni stb. árak legjobb előrejelzése a mai érték. Ennek oka, hogy amennyiben az ár eltolás nélküli véletlen bolyongást követ, akkor a folyamat várható értéke bármely jövőbeli időpontban a legutolsó ismert tényadattal

${ }^{63}$ ARX (autoregressive exogenous model): exogén változókkal bővített augoregresszív modell.

${ }^{64}$ LPM (linear probability model): lineáris valószínűségi modell. 
egyezik meg. Ez a megközelítés persze (egy-két kivételes alkalomtól eltekintve) soha nem fogja eltalálni a változás irányát. A modell formálisan:

$$
\begin{aligned}
& p_{t}=p_{t-1}+\varepsilon_{t} \\
& \hat{p}_{t-1+m}=p_{t-1}
\end{aligned}
$$

Ahol $p_{t}$ a t. időszak spot ára, $\hat{p}_{t}$ az erre vonatkozó elörejelzés, $\varepsilon_{t}$ az autokorrelálatlan hibatag, $m$ pedig az elörejelzési időszak hossza (jelen esetben $m=1,2,3$ ).

Egy másik lehetőség az eltolásos véletlen bolyongás használata:

$$
\begin{gathered}
p_{t}=\propto+p_{t-1}+\varepsilon_{t} \\
\hat{p}_{t-1+m}=m \cdot \widehat{\alpha}+p_{t-1}
\end{gathered}
$$

Ahol $\propto$ az eltolás mértéke (drift), $\widehat{\alpha}$ pedig ennek becsült értéke.

\section{IV.2.2. Ökonometriai modellek}

Az elemzés során olyan standard ökonometriai eljárásokkal dolgozom, amelyek felhasználási területe meglehetősen széles, így részletekbe menő ismertetésüktől ezúttal eltekintek, csak az eredmények értelmezéséhez feltétlenül szükséges pontok bemutatására szorítkozom.

\section{ARIMA}

Az ARIMA(p,d,q) modellnél $p$ jelöli az autoregresszív tagok számát, $d$ az idősor integráltságának fokát (hányszori differencia képzés után lesz stacionárius), $q$ pedig a mozgó átlagolású tagok számát:

$$
y_{t}=\beta_{0}+\beta_{1} y_{t-1}+\ldots+\beta_{p} y_{t-p}+\varepsilon_{t}+\gamma_{1} \varepsilon_{t-1}+\ldots+\gamma_{q} \varepsilon_{t-q}
$$

Ahol $y_{t}$ a függő változó értéke a t. periódusban, $\varepsilon_{t}$ pedig az autokorrelálatlan hibatag. Mivel az eljárás csak stacionárius idősorokra érvényes, $y_{t}$ nem a spot árat, hanem annak 
transzformált alakját, a logaritmikus differenciát jelöli (ez a módosítás az összes, később ismertetendő elörejelzésnél is megtörténik):

$$
y_{t}=\ln \left(p_{t}\right)-\ln \left(p_{t-1}\right)
$$

$\mathrm{Az}$ egyenlet paramétereit likelihood eljárással becsülöm a MATLAB R2013a programcsomag Econometrics Toolboxának segítségével. A kiértékeléskor természetesen nem a transzformált változó dinamikus előrejelzéseit vizsgálom, hanem az abból nyert, az eredeti változóra (a nominális spot árra) vonatkozó projekciókat. Az ARIMA modellezés során két megközelítést alkalmazom:

- minden év elején az addig rendelkezésre álló adatokon megbecsülöm az $\operatorname{ARIMA}(\mathrm{p}, 1, \mathrm{q})$ modelleket $(p, q=1 ; \ldots, 10)$ majd a Schwarz információs kritérium $^{65}$ alapján kiválasztom a becslési mintán legjobban teljesítő beállítást, és a következő 12 hónapban végig ezzel a modellel végzem az 1-3 napos dinamikus elörejelzést ${ }^{66}$

- minden nap elején az akkor rendelkezésre álló adatokon megbecsülöm az $\operatorname{ARIMA}(\mathrm{p}, 1,0)$ modellt $(p=1 ; \ldots ; 20)$, majd ebböl készítek - szintén 1-3 napos, dinamikus - kivetítést ${ }^{67}$

$A R X$

Az exogén változókkal bővített autoregresszív modell az ARIMA(p,d,0) modell egy kiterjesztésének tekinthető. Az előző pontban ismertetett modellhez képest annyi változás figyelhető meg, hogy újabb magyarázó változókkal bővül az egyenlet:

$$
y_{t}=\beta_{0}+\beta_{1} y_{t-1}+\ldots+\beta_{p} y_{t-p}+\gamma_{1} x_{t-m}+\ldots+\gamma_{s} x_{t+1-m-s}+\varepsilon_{t}
$$

\footnotetext{
${ }^{65}$ SIC $=-2 \cdot \ln (L)+k \cdot \ln (n)$, ahol $L$ a likelihood függvény értéke, $k$ a becsülendő paraméterek, $n$ pedig a megfigyelések száma.

${ }^{66}$ Azaz év elején a rendelkezésre álló adatok alapján kiválasztom az alkalmazandó modell formáját (ez egyébként minden alkalommal az $\operatorname{ARIMA}(0 ; 1 ; 1)$ alakot jelenti), megbecsülöm a paramétereket, majd az újonnan érkező adatokat ebbe a modellbe helyettesítve készítek előrejelzéseket. A következő év elején megismétlem az eljárást, és frissítem a paramétereket.

${ }^{67}$ Az ARIMA modellekhez tartozó számítási igény meglehetősen nagy, míg az AR(p) modellek közvetlenül becsülhetők OLS-sel, így hamar lefutnak, és utólag is könnyen előállítható a valós idejü, napi szinten frissülő előrejelzések idősora. Az MA tagokat ezért a későbbiek során is kihagyom az elemzésből.
} 
Ahol $x_{t}$ a bevont magyarázó változó t. időszaki értéke, $\gamma_{j}$ pedig a megfelelő késleltetéshez tartozó koefficiens. Látható, hogy minden esetben az $x$ változónak csak az előrejelzés időpontjában már ismert (legalább $m$ nappal korábbi) értékei kerülnek az egyenletbe $(m=1 ; 2 ; 3)$, míg a spot olajár esetén már az 1 nappal korábbi érték is (dinamikus elörejelzés). A modell paraméterei naponta frissülnek.

Ahogy a felírásból is kitünik, az exogén magyarázó változó maximális késleltetése nem feltétlenül esik egybe a függő változó hasonló paraméterével. Emellett az alkalmazások során előfordul, hogy nemcsak egy, hanem több magyarázó változó szerepel a modellben, ekkor a fenti egyenlet értelemszerűen újabb $x$ változókkal bővül (az egyszerüség kedvéért itt is felteszem, hogy a késleltetések száma $s$, azaz minden exogén változó esetén ugyanannyi). Az egyes modelleknél ez a következő változókat takarja:

(1) futures árak és/vagy olajszármazékok (benzin, fütőolaj) dlog idősorainak késleltetett értékei, ahol $p=s$ és $p=1 ; \ldots 20$ :

$$
y_{t}=\beta_{0}+\beta_{1} y_{t-1}+\ldots+\beta_{p} y_{t-p}+\gamma_{1} d \log \left(p_{t-m}^{x}\right)+\ldots+\gamma_{p} d \log \left(p_{t+1-m-p}^{x}\right)+\varepsilon_{t}
$$

Ahol $p_{t}^{x}$ a bevont futures termék vagy olajszármazék tőzsdei jegyzése az alsó index szerinti időpontban.

A futures árak késleltetett értékeinek szerepeltetését Haidar és Kulkarni [2009] eredményei indokolják. Ez a megoldás azért javíthat az előrejelzésen, mert egyes kutatások szerint a futures piacok nagyobb likviditása miatt az információk itt hamarabb beépülnek az árakba, mint a spot piacon (Silvapulle és Mossa [1999]). Valószínüsíthető ugyanakkor, hogy a hatás erősebben jelentkezik a napon belüli, órás vagy még részletesebb bontású kereskedési adatokon (Brooks et al. [2001]), így csak a konkrét eredmények ismeretében lehet eldönteni, hogy napi bontásnál is érdemes-e bevonni az új változókat.

Ehhez hasonlóan megvizsgálom, hogy a benzin és fütőolaj árak változásának felhasználásával javítható-e a modell elörejelző képessége. Az olajszármazékok ára ekkor a végtermék iránti kereslet proxyjaként funkcionál, ami később a nyersolaj piacán is megjelenik. Problémát jelent azonban, hogy az árváltozás gyakran a termelési költség növekedéséből ered, ilyenkor pedig az ok-okozati szerepek felcserélődnek (a nyersolaj 
drágulása a benzin áremelkedését eredményezi), így szintén csak az eredmények ismeretében lehet dönteni e változók szükségességéről.

Bizonyos esetekben nem egyetlen plusz idősorral bővül az egyenlet. Összesen 6 változó 9 kombinációját tesztelem, azaz y késleltetett értékei mellet az alábbi tagok szerepelnek az egyenlet jobb oldalán (a változók pontos leírását később ismertetem):

- futures árak: 1, 2, 3 ill. 4 ,hónapos” futures árak szerepeltetése együtt és különkülön (5 eset)

- olajszármazékok: benzin és fütőolaj spot árak szerepeltetése együtt és különkülön (3 eset)

- teljes modell: a 4 olaj futures és a két olajszármazék spot ár együttes szerepeltetése (1 eset)

Az alkalmazott módszertantól függetlenül mindig ezt a 9 esetet vizsgálom, azaz a spot olajár késleltetett értékei mellé a fenti idősorok megfelelő (dlog vagy spread) transzformációi kerülnek az elemzésbe, függetlenül attól, hogy milyen modellről van szó. A későbbiekben ezért eltekintek a változók körének részletes felsorolásától.

(2) a spot olajár logaritmusának és az olaj futures vagy benzin/fütőolaj árak logaritmusainak különbsége (spread), ahol $p=1 ; \ldots 20, x$-ek esetén pedig kizárólag az utolsó ismert spread érték szerepel az egyenletben:

$$
y_{t}=\beta_{0}+\beta_{1} y_{t-1}+\ldots+\beta_{p} y_{t-p}+\gamma\left[\ln \left(p_{t-m}^{x}\right)-\ln \left(p_{t-m}\right)\right]+\varepsilon_{t}
$$

Baumeister et al. [2013] havi adatokon megmutatták, hogy hosszú távon az olaj reálárának előrejelzését javítja a benzin és fütőolaj spread értékek használata. Javulás alatt azt értették, hogy a változatlan áras előrejelzéshez képest akár 20\%-kal is csökkenteni lehetett az előrejelzés átlagos négyzetes hibáját. Kérdés, hogy ez 1-3 napos viszonylatban is teljesül-e, amit szintén megvizsgálok. Ennek mintájára a futures árakra is elvégzem az elemzést, ezek ugyanis a jövőbeli spot árakra vonatkozó piaci várakozást tükrözik ${ }^{68}$.

68 Bár mint korábban szóba került, a futures árak nem tekinthetők a jövőbeli spot árak torzítatlan elörejelzéseinek. 


\section{Bináris függö változós modellek}

Amennyiben a modellező célja nem az árnak hanem az árváltozás irányának minél pontosabb előrejelzése, akkor bináris függő változós modellek segítségével lehetőség van ennek közvetlen becslésére. A bemutatásra kerülő eljárásokat kizárólag egynapos projekciókhoz használom, mivel a később ismertetendő profitfüggvény maximalizálásához nincs szükség ennél hosszabb kitekintésre. A korábbiakhoz hasonlóan ezeknél a modelleknél is napi szinten frissítem a paramétereket.

(1) Lineáris valószínűségi modell (LPM)

Az LPM regresszió egy bináris (0/1) függő változós modell OLS becslése, ahol a függő változó várható értéke a bekövetkezési valószínüséggel egyenlő. Az előrejelzés során az alábbi egyenletet használom:

$$
D_{t}=\beta_{0}+\beta_{1} y_{t-1}+\ldots+\beta_{p} y_{t-p}+\gamma_{1} x_{t-m}+\ldots+\gamma_{s} x_{t+1-m-s}+\ldots+\varepsilon_{t}
$$

Ahol $D_{t}$ a növekedés dummy a t. időszakban, melynek értéke 1 , ha $t$-ben magasabb az ár, mint $t$-1-ben, különben $0^{69}$. A változók köre - és a késleltetési struktúra - pontosan ugyanaz, mint a korábbi modellekben, azaz kifejezhetik:

- a spot olajár logaritmikus differenciájának késleltetett értékeit

- a futures olajárak logaritmikus differenciájának késleltetett értékeit vagy a spot árhoz képesti spread-et (ezúttal is az árak logaritmusai közti különbségként definiálva)

- a különböző olajszármazékok hasonló transzformációt (dlog és spread)

Mivel outputként nem egy konkrét kimenetet (növekedés vagy csökkenés), hanem egy bekövetkezési valószínűséget generál a modell, az előrejelzéshez meg kell adni egy $c$ küszöbértéket, ami alapján létrejön a projekció:

$$
D_{t}^{\text {pred }}=\left\{\begin{array}{l}
1, \text { ha } \widehat{D_{t}}>c \\
0, \text { különben }
\end{array}\right.
$$

\footnotetext{
${ }^{69}$ Formálisan: $D_{t}=\max \left[0 ; \operatorname{sign}\left(p_{t}-p_{t-1}\right)\right]$.
} 
Ahol $D_{t}^{\text {pred }}$ a t. időszakra vonatkozó elörejelzés ( 1 , ha növekedés, 0 , ha csökkenés), $\widehat{D_{t}}$ pedig az LPM modellből becsült valószínüség. Az alkalmazások során a $c=0,5$ (50\%-os küszöbszint) feltevéssel élek.

\section{(2) Logisztikus regresszió (logit)}

Az LPM modellel kapcsolatban gyakori kritika, hogy a becsült valószínüség nem feltétlenül esik a $(0 ; 1)$ intervallumba (kivéve, ha kizárólag dummy változókkal dolgozunk), illetve a hibatag heteroszkedaszticitása miatt a szokásos tesztek érvénytelenek. Ugyanakkor az olajár-változás irányának előrejelzése szempontjából az LPM legnagyobb hátulütője, hogy nehezen boldogul a nemlineáris dinamikák leírásával. A logit modell ennél szofisztikáltabb, és több területen is sikerrel alkalmazott módszernek számít. Az eljárás egy látens - nem megfigyelhető - változós modellből indul ki:

$$
D_{t}^{*}=\beta_{0}+\beta_{1} y_{t-1}+\ldots+\beta_{p} y_{t-p}+\gamma_{1} x_{t-m}+\ldots+\gamma_{s} x_{t+1-m-s}+\ldots+\varepsilon_{t}
$$

Amennyiben ez a látens $\left(D^{*}\right)$ változó eléri a kritikus értéket (meghaladja a nullát), akkor az esemény bekövetkezik (az olajár nő), különben a függő változó 0 értéket vesz fel (az olajár csökken):

$$
D_{t}=\left\{\begin{array}{l}
1, \text { ha } D_{t}^{*}>0 \\
0, \text { különben }
\end{array}\right.
$$

Az előrejelzés elvégzéséhez tehát csak az x magyarázó változók és a $\beta$ paraméterek ismeretére van szükség. Mivel a látens változót nem lehet megfigyelni, ezért a likelihood - becslés elvégzéséhez konkrét feltételezéssel kell élni az $\varepsilon$ hibatag valószínüségi eloszlásáról. Sajnos nincs olyan teszt, ami megmutatná, milyen eloszlásfüggvénnyel érdemes dolgozni, hiszen maga a hibatag is egy látens változó. Az alkalmazások többsége ezért két könnyen kezelhető esettel, a standard logisztikus (logit) és a standard normális (probit) eloszlással számol. Megmutatható (lásd Wooldridge [2012]), hogy ebben az esetben a bekövetkezés valószínűsége:

$$
P\left(D_{t}=1 \mid Y, X\right)=G\left(\beta_{0}+\beta_{1} y_{t-1}+\ldots+\beta_{p} y_{t-p}+\gamma_{1} x_{t-m}+\ldots+\gamma_{s} x_{t+1-m-s}\right)
$$


Ahol $G(\cdot)$ a hibatag valószínűségi eloszlásához tartozó eloszlásfüggvény ${ }^{70}$. Az innen nyert elörejelzések ismét bekövetkezési valószínüségek lesznek, így most is egy küszöbszint (továbbra is $c=0,5$ ) alapján kell eldönteni, hogy növekedés vagy csökkenés várható a következő napon ${ }^{71}$.

Itt érdemes megjegyezni, hogy a logit modellt ritkán használják idősoros elemzésekhez, mivel sérül a megfigyelések függetlenségének feltétele. Jelen esetben viszont a fellépő autokorreláció kevésbé számít, mert a cél nem a magyarázó változók parciális hatásának vagy a komplett adatgeneráló folyamatnak a feltárása, hanem az árváltozás irányának elörejelzése.

\section{IV.2.3. Gépi tanulás}

Az ökonometriai modellekhez képest jóval általánosabb, komplexebb függvényformákkal dolgoznak a most bemutatásra kerülő gépi tanulásos módszerek. Így viszont a paraméterek kalibrációja is nehezebb, és - föleg a neurális hálóknál - könnyen előfordulhat, hogy az iterációs eljárás lokális optimumba konvergál. Ez nem csupán az elörejelzési képességet rontja, de az eredmények reprodukcióját is ellehetetleníti. Ezért bár a paraméterek végleges értékeit külön nem közlöm - a leírásban minden olyan beállítást megnevezek, amivel a szimulációs eredmények megismételhetők.

Az SVM eljárást a törzszövegben csak röviden tárgyalom, a részletes módszertani leírást a Függelék (F.1.) tartalmazza.

\section{Neurális háló}

A neurális hálóknak számos típusa létezik, itt most kizárólag a közgazdasági alkalmazásokban leggyakrabban használt, 3 rétegü előrecsatolt neurális hálóval foglalkozom. Az eljárás során a bemeneti réteg neuronjai az input adatokat jelentik, ahonnan az információ a rejtett rétegbe kerül, melyben tetszőleges számú neuron található. A neuronok mindegyike egy-egy függvényt jelöl, ami a kapcsolódó input neuronokból származó változók értékeit transzformálja:

\footnotetext{
${ }^{70}$ Standard logisztikus eloszlásnál ez épp a szigmoid függvény: $G(a)=\frac{1}{1+e^{-a}}$

${ }^{71}$ Megjegyzendő, hogy a küszöbszint nagysága itt és az LPM-nél is a modellező konkrét céljának függvényében optimalizálható.
} 


$$
s_{k t}=f\left(\sum_{i=1}^{p} w_{i k}^{y} y_{t-i}+\sum_{j=1}^{s} w_{j k}^{x} x_{t+1-m-j}+c_{k}\right)
$$

Ahol $s_{k t}$ a rejtett rétegben lévő k. neuron által adott függvényérték a t. időszakban, $w_{i k}^{y}$ és $w_{j k}^{x}$ az input változók k. neuronhoz tartozó súlyai (koefficiensei), $c_{k}$ a neuronhoz tartozó torzítás (konstans tag), $f(\cdot)$ pedig az alkalmazott (jelen esetben szigmoid) függvényforma.

A rejtett réteg így $J$ darab ( $J$ a rejtett rétegben található neuronok száma) értéket ad eredményül. Ezek az „outputok” a kimeneti rétegben található neuron inputjaiként szolgálnak, ahol egy függvény transzformálja őket egyetlen számmá, a függő változó elörejelzésévé:

$$
y_{t}=g\left(\sum_{k=1}^{J} w_{k} s_{k t}+c\right)
$$

Ahol $w_{k}$ a rejtett réteg $\mathrm{k}$. neuronjából érkező input súlyát (koefficiensét), $c$ a torzítási együtthatót, $g(\cdot)$ pedig a transzformációs függvényt (identitásfüggvény) jelöli. A háló felépítését a 33. ábra mutatja:

33. ábra: A használt elörecsatolt neurális háló sematikus ábrája

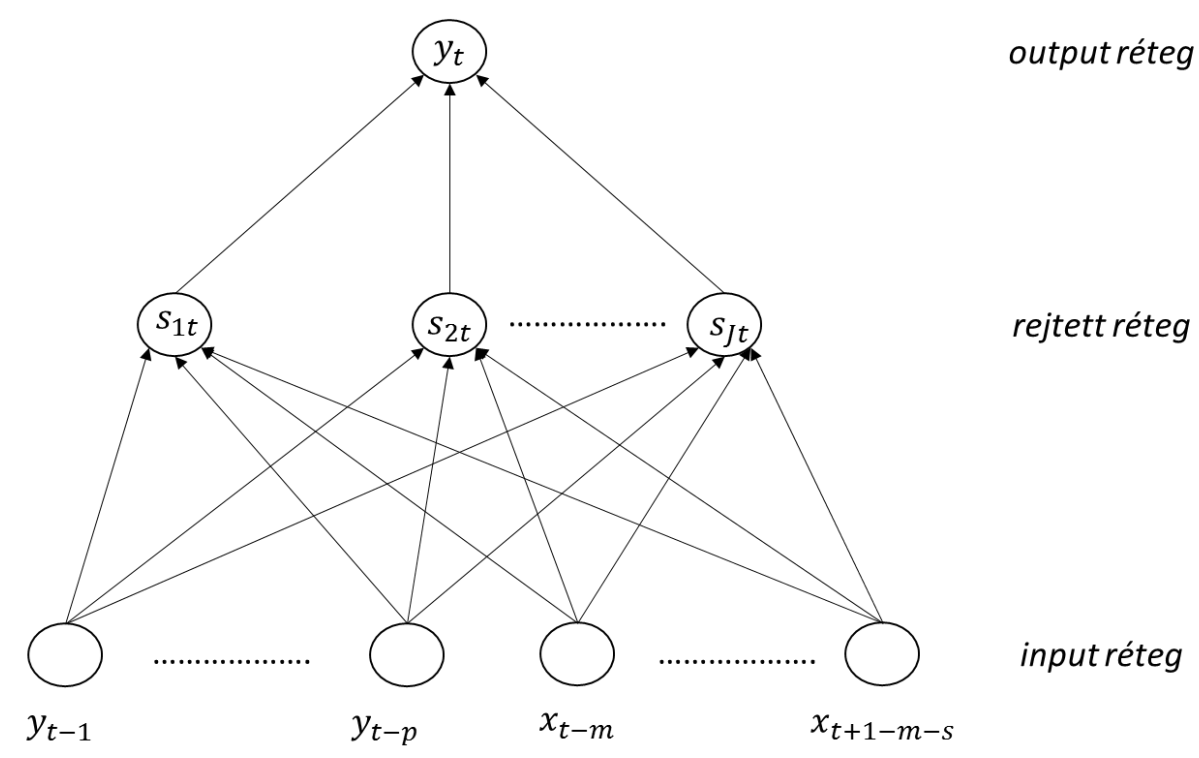


Ahogy a leírásból kitünik, a módszer lényegében egy bonyolult nemlineáris függvény előállítását végzi. Mivel a fent ismertetett struktúra (szigmoid függvények a rejtett rétegben, lineáris függvény a kimeneti rétegben), a függvények egy meglehetősén széles halmazának közelítésére képes, a modellezőnek nem kell konkrét összefüggésrendszert felírnia, és annak paramétereit becsülnie, ezt az algoritmus teszi meg helyette, és az adatok alapján dönt arról, melyik formula használata a legkifizetődőbb. Ezzel el is értünk a lényegi kérdésekhez, a modellező feladatához. A modellezőnek az alábbiakról kell döntenie:

- input adatok (mi kerüljön a háló bemeneti rétegébe, az adatok milyen transzformáción/szürésen essenek át elötte)

- rejtett rétegek száma, a rejtett és kimeneti rétegek neuronjainak száma

- célfüggvény

- tanuló algoritmus típusa és annak beállításai

Az input és output adatok a korábban is alkalmazott változókat takarják, de a tanulás gyorsítása ill. a szigmoid függvény korlátos értéktartománya miatt elöbb a $[0 ; 1]$ intervallumba transzformálom őket a következő képlet segítségével (lásd Badics [2014]):

$$
x=\frac{x^{\text {eredeti }}-x^{\min }}{x^{\max }-x^{\min }}
$$

Arra is figyelni kell azonban, hogy valós idejü előrejelzés esetén az idősor minimum és maximum értékei folyamatosan változhatnak, ezért azokat mindig az előrejelzés pillanatában már rendelkezésre álló, a tanuló vagy validációs mintában is szereplő időszak szélsőértékeivel azonosítom.

A kísérletek során egy rejtett réteget használok 10 neuronnal, míg a kimeneti rétegben értelemszerüen egyetlen neuronnal dolgozom. A túlillesztés elkerülése érdekében keresztvalidációs eljárást alkalmazom, és a mintát tanuló, validációs, valamint teszt részekre bontom. A tanuló algoritmus arra törekszik, hogy a célfüggvényt, jelen esetben az átlagos négyzetes hibát minimalizálja a tanuló mintán, de a tanulási folyamat során úgy változtatja a súlyok és a torzítási tényezők értékeit, hogy az új értékeket csak akkor tartja meg, ha azok a validációs mintán is javítják az illeszkedést. Azaz a tanuló minta határozza meg, hogy milyen irányban és mértékben változzanak a paraméterek, de az így nyert függvény teljesítőképességét a validációs mintán is teszteli az algoritmus, és elveti 
a módosításokat, ha ott a hibamutató növekedését tapasztalja. A tesztminta csupán ellenőrzésre szolgál, a tanulás során ezek az információk nem kerülnek felhasználásra. A keresztmetszeti alkalmazásokkal ellentétben, idősoroknál a minta felosztását nem célszerü véletlenszerüen elvégezni, ezért jelen esetben a tanuló minta mindig megelőzi az 1 éves validációs mintát, azt pedig a szintén 1 éves tesztminta követi (ennek pontos specifikációjára később még visszatérek). Ez egyben azt is jelenti, hogy a korábbiakkal ellentétben a modell évente csak egyszer frissül, és a következő 12 hónapban beérkező input adatok nem befolyásolják a kalibrációt (hasonlóan az ARIMA modellhez). A paraméterek becslése a Levenberg-Marquardt (LM) féle hiba-visszaterjesztéses (backpropagation) módszerrel történik, a szimulációkat a MATLAB Neural Network Toolbox segítségével végzem.

A Levenberg-Marquardt módszer lényege, hogy néhány véletlenszerüen kiválasztott súllyal és torzítással megbecsüli a kimeneti változó értékét az egyes megfigyelésekre, majd a tanuló mintán elkövetett hiba alapján, a Jacobi mátrix segítségével módosítja a paramétereket. Az új paraméterekkel ismét kiszámolja az outputokat és az így elkövetett hibákat, és csak akkor tartja meg a változtatásokat, ha azok a validációs mintán is csökkentették az MSE értékét. Az iteráció akkor zárul le, amikor 6 egymást követő módosítás egyike sem tudja csökkenteni a validációs mintán mért hibát ${ }^{72}$.

Mivel az iterációs folyamat a kezdőértékek függvényében eltérő eredményre vezethet, ezért minden alkalommal 50 szimuláció történik, és az így nyert elörejelzések illeszkedési mutatóit átlagolom, ezzel csökkentve annak lehetőségét, hogy egy-egy kiugróan jó/rossz elörejelzés torzítsa a modell teljesítményének megítélését ${ }^{73}$. Hangsúlyozandó, hogy ezzel a módszerrel nem egy konkrét előrejelzés, hanem az eljárás hatékonyságát mérem, és könnyen elképzelhető, hogy nincs is olyan kivetítés, melynek teljesítménye épp a használt illeszkedési mutató értékeinek átlagával egyezne meg.

A neurális hálókkal történő előrejelzés során az ökonometriai részben ismertetett felírásokat használom:

\footnotetext{
${ }^{72}$ Ezt és az LM eljáráshoz tartozó többi Matlab alapbeállítást is megtartom.

${ }^{73}$ A futásszám optimális értékének meghatározására nincs univerzális szabály, jelen esetben azért esett 50re a választás, mert az eredmények vizsgálatakor kiderült, hogy bár az esetek többségében 20-30 ismétlés is elég a konvergenciához, alkalmanként ennél tovább kell menni. Az 50-es beállítás ezekben a helyzetekben is elégnek bizonyult, így az összes esetben ezzel az értékkel dolgoztam.
} 
- nemlineáris autoregresszív (NAR) modell $p$ késleltetéssel, amikor csak a kimeneti változó késleltetett értékei $(p=1 ; 5 ; 10 ; 15 ; 20)$ kerülnek a modellbe

- nemlineáris autoregresszív (NARX) modell, amikor NAR-hez képest exogén (dlog és spread) változókkal bővül a modell, $p=1$ késleltetés mellett ${ }^{74}$

Az NARX modell esetén a dinamikus előrejelzés módszere némileg eltér a korábban bemutatott megoldástól, mivel a 2 ill. 3 napos előrejelzések során a becsléshez kizárólag az előrejelzések pillanatában már rendelkezésre álló adatok kerülnek felhasználásra. Ez azt jelenti, hogy minden egyes futás során 3 különböző (1, 2 ill. 3 napos) elörejelzés keletkezik az árváltozás nagyságára vonatkozóan $\left(\hat{y}_{t+1}, \hat{y}_{t+2}, \hat{y}_{t+3}\right)$ amikből már visszaszámolható az árszintre vonatkozó kivetítés.

\section{Neurális háló az irány elörejelzésére}

A fenti modell mintájára építhető olyan hálózat, ahol a bemeneti és a rejtett réteg szerkezete megegyezik a korábbival, de a kimeneti rétegben két neuron van, melyek a csökkenés/növekedés kategóriákat jelölik. Az LPM és logit modellek mintájára ezzel a konstrukcióval is elvégzem az 1 napos árváltozás irányának előrejelzését.

Az eredeti hálóhoz képest mutatkozó különbségek:

- a kimeneti rétegben két neuron van, mindkettő egy-egy szigmoid függvényt takar

- az output két szám lesz, ezek közül a nagyobb érték mutatja meg, hogy melyik kimenet (növekedés vagy csökkenés) a valószínübb

- amikor kizárólag a spot olajár késleltetett dlog értékei szerepelnek a modellben (NAR mintájára), akkor a $p=1 ; \ldots ; 20$, míg a másik két esetben (NARX mintájára) a $p=1 ; 5 ; 10 ; 15 ; 20$ késleltetéseket vizsgálom

- a benzin és a fütőolaj változókat együtt vagy külön-külön bevonó modelleknél a paraméterek változtatása a skálázott konjugált grádiens (SCG, scaled conjugate gradient) módszerrel történik, míg minden más esetben a Levenberg-Marquardt eljárást használom ${ }^{75}$

\footnotetext{
${ }^{74} p=1$-re azért esett a választás, mert az NAR modellek közül NAR(1) adta a legpontosabb elörejelzéseket.

${ }^{75}$ Futures árak használata mellett az SCG eljárás még 1000 iteráció után sem találta meg az optimumot, és jellemzően a tesztminta minden napján az árak csökkenését tartotta valószínübbnek. Az LM módszerrel sikerült kiküszöbölni a hibát.
} 
A célfüggvény továbbra is az átlagos négyzetes hiba (MSE), a paraméterek évente frissülnek, és ezúttal is 50 futás eredményeit átlagolom.

\section{Support vector machine (SVM)}

Az SVM (support vector machine) eljárás során az algoritmus egy hipersíkkal osztja két részre a teret, és az egyes megfigyelések klasszifikációja attól függ, hogy e hipersík melyik oldalán találhatóak. Könnyen belátható azonban, hogy teljes szeparálhatóság esetén, amikor létezik a két kategória elemeit 100\%-os pontossággal elválasztó hipersík, végtelen sok lehetőség közül választhatunk. Az SVM ezek közül azt a hipersíkot keresi meg, ami a két csoport „széleitől” egyenlő, és a lehető legnagyobb távolságra van. A kategóriák ,szélei” azokat a megfigyeléseket, ún. tartóvektorokat (support vectors) jelentik, amelyek hipersíktól vett távolsága a legkisebb. Matematikailag ez a következő optimalizálási feladat megoldását jelenti ${ }^{76}$ :

$$
\begin{gathered}
\min _{w, b, s}\left(\frac{1}{2}\langle w, w\rangle+c \sum_{t=1}^{n} s_{t}\right) \\
\text { s.t.: } \forall t-r e D_{t}\left(\left\langle w, x_{t}\right\rangle+b\right) \geq 1-s_{t}, \text { ahol } s_{t} \geq 0
\end{gathered}
$$

Ahol $w$ és $b$ a hipersíkot meghatározó paraméterek $(\langle w, x\rangle+b=0), D_{t} \in\{-1 ; 1\}$ a kimeneti változó értéke (csökken vagy nő az ár), $x_{t}$ a mintában található t. megfigyelés vektora (k. eleme mutatja, hogy a t. megfigyelés esetén mekkora a k. változó értéke), $s_{t}$ egy nemnegatív segédváltozó, ami akkor és csak akkor vesz fel nulla értéket, amikor a t. megfigyelés klasszifikációja helyes ${ }^{77}$. A hibás besorolás relatív költségét szabályozó $c$ paraméter értékét 1-re állítom, a bevont változókat pedig sztenderdizálom. Ezen túlmenően egy kernel függvényt (a Gaussi radiális bázisfüggvényt) vezetek be, ami lehetővé teszi az eredeti térben történő nemlineáris szeparációt:

$$
K(a, b)=\exp \left[\frac{-\langle(a-b)(a-b)\rangle}{2 \sigma^{2}}\right]
$$

\footnotetext{
${ }^{76} \mathrm{Az}$ itt ismertetett $\mathrm{L}^{1}$-norma felírás alternatívája az $\mathrm{L}^{2}$ norma használata, ahol az $s_{t}$ segédváltozó négyzete szerepel a célfüggvényben.

${ }^{77}$ Tartóvektor esetén pedig $s_{t}=0$ mellett az is igaz, hogy a feltétel egyenlőségre teljesül.
} 
A $\sigma^{2}$ paraméter értékét szintén 1-re állítom a futások során, de ahogyan a neurális hálónál a neuronok számára, úgy itt erre és $c$-re is igaz, hogy változtatásuk révén optimalizálható az eljárás. A korábban felírt (primál) feladat egyetlen ponton változik, a feltételben $\left\langle w, x_{t}\right\rangle$ helyett $\left\langle w, \varphi\left(x_{t}\right)\right\rangle$ szerepel, ahol $K(a, b)=\langle\varphi(a), \varphi(b)\rangle$. A paraméterek becslése a duál feladat megoldásával történik SMO (sequential minimal optimization) eljárással.

Az előrejelzések során a kategória változó továbbra is az olajár növekedését $(D=1)$ vagy csökkenését $(D=-1)$ jelöli 1 napos távlatban, míg a szétválasztás a korábban is alkalmazott változók és $p=1 ; \ldots ; 20$ késleltetés mentén történik. A modell becslését és a szeparáló hipersík kialakítását itt is évente végzem: az év elején az addig rendelkezésre álló adatokon megkeresem a szeparáló hipersíkot, a következő 12 hónapban pedig attól függően adok növekvő/csökkenő elörejelzést az olaj árára, hogy a bevont változók alapján a hipersík mely oldalára esik az új megfigyelés ${ }^{78}$. Az SVM klasszifikáció a MATLAB Statistics Toolbox-ával történik.

\section{IV.2.4. Eredmények kiértékelése}

A modellek teljesítményének mérésére nem létezik univerzális mutató. Könnyen előfordulhat, hogy egy kutató közgazdász számára a „pontosság” egészen mást jelent, mint egy kereskedőnek, és még e kategóriák is tovább bonthatók. Elképzelhető, hogy az egyik kereskedőnek olyan eljárásra van szüksége, amely nagy biztonsággal jelzi, hogy milyen irányba mozdulnak az árak, míg a másiknak elég, ha az elmozdulás nagyságának abszolút értékét ismeri. A példákat sokáig lehetne sorolni, de a lényeg, hogy a modellek kiértékelése nem történhet egyetlen mutató alapján, így a következőkben több lehetőséget is megvizsgálok.

A pontbecslés jóságát az átlagos abszolút hibával (MAE) és az átlagos négyzetes hiba gyökével (RMSE) mérem:

$$
M A E=\frac{\sum_{t=1}^{n}\left|p_{t}-\widehat{p_{t}}\right|}{n}
$$

\footnotetext{
${ }^{78}$ A paraméterek frissítésének 12 havonta történő elvégzése ugyan nem a legoptimálisabb eljárás, azonban a becslések futási ideje miatt ennél gyakoribb ismétlésre nem volt mód. Könnyen elképzelhetö, hogy a modellek havonta/negyedévente történő kalibrációja pontosabb elörejelzésekhez vezetne. Erre a IV.5. alfejezetben még visszatérek.
} 


$$
R M S E=\sqrt{\frac{\sum_{t=1}^{n}\left(p_{t}-\widehat{p_{t}}\right)^{2}}{n}}
$$

Ahol $p_{t}$ a nyersolaj piaci ára az t. periódusban, $\widehat{p_{t}}$ az erre adott előrejelzés, $n$ pedig az előrejelzések száma. A kiértékelés 2011 januárjától évente történik, így az első 3 évben rendre $n=252$, míg 2014-ben $n=211$ napnyi elörejelzésre számolom ki a fenti mutatókat (1, 2 és 3 napos kivetítésre egyaránt). Míg az abszolút hiba arányosan bünteti az eltéréseket, addig az RMSE nagyobb hibához nagyobb súlyt rendel. A kereskedés során fontos, hogy egy szerencsétlenül megválasztott pozíció esetén se legyen túl nagy a keletkező veszteség, ezért ilyenkor érdemesebb RMSE szerint értékelni a versenyző modellek teljesítményét.

Ami legalább ilyen fontos a piaci szereplöknek, az a változás iránya: ha pontosan tudnák, hogy milyen irányba fog változni az olaj ára, akkor tulajdonképp az árváltozás mértékét sem kellene ismerniük ahhoz, hogy nyereséges stratégiát építsenek. Ezért a modellek azon képességét, hogy milyen jól jelzik előre az elmozdulás irányát, a találati rátával jellemzem (az esetek hány százalékában sikerült helyesen prognosztizálni az árváltozás elöjelét $)^{79}$ :

$$
D A=\frac{\sum_{t=1}^{n} \max \left[\operatorname{sign}\left(\Delta p_{t}\right) \cdot \operatorname{sign}\left(\Delta \widehat{p_{t}}\right), 0\right]}{n}
$$

A találati arány használatának egy másik előnye, hogy segítsével összevethető a pont és az irány-előrejelzést adó modellek teljesítménye, míg MAE és RMSE szempontjából utóbbiak nem értelmezhetők.

Mivel a találati ráta sosem lesz 100\%, ezért korántsem biztos, hogy egy magasnak tünő arány elég a sikeres kereskedéshez. Ha például valaki az esetek 70\%-ban a jó irányra „tesz”, de ezzel minden esetben csak mérsékelt hozamot realizál, miközben a maradék 30\%-ban többször is nagyot bukik, akkor könnyen lehet, hogy mínuszban zár. Ezért szokás nem csupán a találati arányt vizsgálni, hanem a fals pozitív/negatív előrejelzések arányát, illetve azok költségvonzatát figyelembe venni. Ezért az eredmények kiértékelése

\footnotetext{
79 A tesztmintán (2011-2014) egyszer sem fordult elö, hogy két egymást követő kereskedési napon a jegyzések ugyanott zártak volna, azaz $\operatorname{sign}\left(\Delta p_{t}\right)$ sosem volt egyenlő 0 -val.
} 
egy hipotetikus profitfüggvénnyel is megtörténik, mégpedig a következő feltevések mellett:

- a modell 1 napos előrejelzésétől függ, hogy vétel (várhatóan emelkedés) vagy eladás (várhatóan csökkenés) történik

- nincsenek adók és tranzakciós költségek

- mind a vétel, mind az eladás a napi spot záróáron történik

- a kereskedés során a teljes (a kezdetben rendelkezésre álló összeg hozamokkal korrigált értékének megfelelő) összeg felhasználásra kerül

- vásárlás esetén a hozam megegyezik a spot olajárak változásával, eladás esetén a felhasználható összeg egészen addig változatlan, amíg nem történik újabb vásárlás (azaz csökkenő árak előrejelzése esetén a meglévő készlet értékesítése történik a mai záróáron, és csak akkor kerül felhasználásra, ha a kivetítés áremelkedést jósol)

- nincs alternatív befektetési lehetőség (vagy ami ezzel ekvivalens: kizárólag 0\%os hozamú 1 napos betétben vagy olajban lehet tartani a pénzt)

Ennek megfelelően a t. kereskedési napig elért teljes hozam képlete a következő:

$$
\begin{aligned}
\text { PROFIT }_{t} & =I\left(\widehat{p_{t}}>p_{t-1}\right) \cdot\left[\left(1+\text { PROFIT }_{t-1}\right) \cdot \frac{p_{t}}{p_{t-1}}-1\right]+\left[1-I\left(\widehat{p_{t}}>p_{t-1}\right)\right] \\
& \cdot \text { PROFIT }_{t-1}
\end{aligned}
$$

Ahol PROFIT $T_{t}$ a t. időszakra elért hozam $\left(P R O F I T_{0} \equiv 0\right), \quad I($.$) pedig egy$ indikátorfüggvény: ha a t. időszakra vonatkozó előrejelzés meghaladja az utolsó (t-1. napi) tényadatot, akkor $I()=$.1 , azaz vétel történik, különben $I()=$.0 és a készletek értékesítésre kerülnek. Bár a valós kereskedés eredménye ennél jóval összetettebb formulával határozható meg, és számos probléma adódna, ha valaki a spot piacon szeretne spekulálni (záró áron történő kereskedés, piac likviditása, mennyiségi korlátozások stb.), ráadásul az áresésből profitáló pozíciókat is lehet építeni, a fenti mutató elemzéséből több hasznos megállapítás következik majd. 


\section{IV.3. Adatok}

A modelleket a West Texas Intermediate (WTI) olajtípus napi spot árain futtatom. Az adatok forrása az EIA (Energy Information Administration) honlapja. A spot árak között a következő változók szerepelnek (a dátum minden esetben a kereskedési napra vonatkozik):

- WTI spot, napi bontás, USD/hordó (2002.01.02-2014.11.04.)

- New York Harbor Conventional Gasoline spot, napi bontás, USD/gallon (2002.01.02-2014.11.04.)

- New York Harbor Heating Oil No. 2 spot, napi bontás, USD/gallon (2002.01.022014.11.04.)

A benzin és a fütőolaj esetén az 1 hordó $=42$ gallon összefüggés alapján konvertáltam azonos mértékegységre (USD/hordó) a változókat ${ }^{80}$. Emellett a WTI 1, 2, 3 és 4 hónapos, napi bontású futures árait használom (USD/hordó, 2002.01.02.-2014.11.04.) ${ }^{81}$.

Az idősorok nem teljesek, mivel nincs minden nap kereskedés (hétvége, ünnepnapok). Ezért azokat a napokat, ahol nem ismert a WTI spot ár, kihagyom az elemzésből (így például a hétfői ár előrejelzésénél az AR(1) változó a pénteki spot árra vonatkozik). Bár többnyire azonos napokon vannak zárva a piacok, előfordul, hogy míg a WTI spot piacán zavartalanul folyik a kereskedés, addig egy másik piacról nincs információ. A hiányzó megfigyelések okát az adattáblák nem nevezik meg, de viszonylag ritkák, így nem valószínü, hogy szignifikánsan befolyásolnák az eredményeket. Ezért amennyiben a modell által becsült egyenlet jobb oldalán található változó értéke ismeretlen, az adott napot hiányzó megfigyelésként kezelem, és kihagyom az elemzésből. A tesztelési mintán (2011 januárjától 2014 októberéig) nincs ilyen probléma, azaz minden kereskedési napra elvégezhető az elörejelzés.

További probléma, hogy a spread ill. dlog idősoroknál mi történjen abban az esetben, amikor nincs WTI, de van benzin vagy fütőolaj spot ár. Ezeket az eseteket figyelmen kívül hagyom, azaz, ha egy pénteki napra van benzin, de nincs WTI érték, akkor a hétföi

\footnotetext{
${ }^{80}$ Bár 1 hordó valóban 42 gallon, azonos mértékegységről igazából nem beszélhetünk. 1 hordónyi kőolajból ugyanis kevesebb, mint 1 hordónyi olajszármazék állítható elő, és mind a benzin, mind a fütőolaj esetén egyéb összetevők is szükségesek. Ez azonban nem befolyásolja az elörejelzéseket, mivel az árak logaritmikus formában szerepelnek.

${ }^{81}$ Bár szokás 1, 2, 3 ill. 4 hónapos futures árakról beszélni, valójában ez csak durva közelítésnek tekinthető. A pontos definíciókat lásd itt: http://www.eia.gov/dnav/pet/TblDefs/pet_pri_fut_tbldef2.asp.
} 
előrejelzésnél a csütörtöki nap jelenti az utolsó időszakot. Az alacsony esetszám miatt itt megint arra lehet számítani, hogy a becslési eredményt érdemben nem befolyásolják a hiányzó értékek.

Az idősorokat a következő struktúrában használom fel:

- a tanuló minta minden esetben 2002.01.02-án indul (Kilian [2009] szerint a világgazdasági reál aktivitás ettől az évtől kezdve gyorsult fel, amit az ázsiai azon belül is elsősorban a kínai - keresletnövekedés táplált, és az olajpiaci folyamatokat is nagyban befolyásolta)

- a tanuló minta első végpontja 2010.12.31-ére esik, utána folyamatosan tolódik (ökonometriai modelleknél - kivéve ARIMA - mindig 1-1 napot, gépi tanulásnál és ARIMA-nál pedig 1-1 évet ugorva), a választást az indokolja, hogy a neurális hálókhoz használt validációs mintában így nincs 2010 előtti adat, ez pedig mérsékli annak veszélyét, hogy a korábban tapasztalt trendszerüen emelkedő/csökkenő dinamikára tanul rá az algoritmus

- SVM esetén az „éves” előrejelzési periódusok (tesztminták) kezdete rendre 2011.01.03., 2012.01.03., 2013.01.02. és 2014.01.02., míg az ezekhez tartozó utolsó olyan nap, ahonnan még elörejelzés kezdődik rendre 2011.12.30., 2012.12.31., 2013.12.31 és 2014.10.31. ${ }^{82}$

- neurális hálók esetén ez a felosztás annyiban módosul, hogy az eddigi tanuló minta utolsó 1 évét validációs mintának használom, rendre 2010.01.04., 2011.01.03., 2012.01.03. és 2013.01.02. kezdési időpontokkal (a validációs minta utolsó eleme pedig a tesztminta első napját megelőző kereskedési nap lesz)

- a kiértékelés az „éves” tesztmintákon külön-külön történik

A vizsgált időszakban a WTI alakulását a 34. ábra mutatja. Látható, hogy a 2002-ben indult - a dinamikusan bővülő ázsiai kereslet táplálta - árnövekedés egy kisebb megtorpanást követően 2007-től új erőre kapott, majd a pénzügyi válság eszkalálódása nyomán a 2008.07.03-án mért 145,31 USD/hordós csúcsról nagyot zuhant. Később a jegyzés korrigált, és a 80-110 dollár/hordós sávban mozgott ${ }^{83}$. A különbözö

\footnotetext{
${ }^{82}$ Ebből következően egy 2014.10.31-én induló 3 napos elörejelzés október 31-re, ill. november 3-ára és 4-ére is ad becslést.

${ }^{83}$ Ezt követően bőven 80 dollár alá is süllyedt a WTI hordonkénti ára, de az elemzés ezt az időszakot már nem tartalmazza.
} 
olajszármazékok árai 2011-ig ezzel nagyjából együtt mozogtak, onnantól kezdve azonban növekedtek a különbségek (lásd 35. ábra). A futures áraknál nem történt hasonló törés.

34. ábra: Napi WTI spot ár (USD/hordó, 2002.01.02-2014.11.04.)

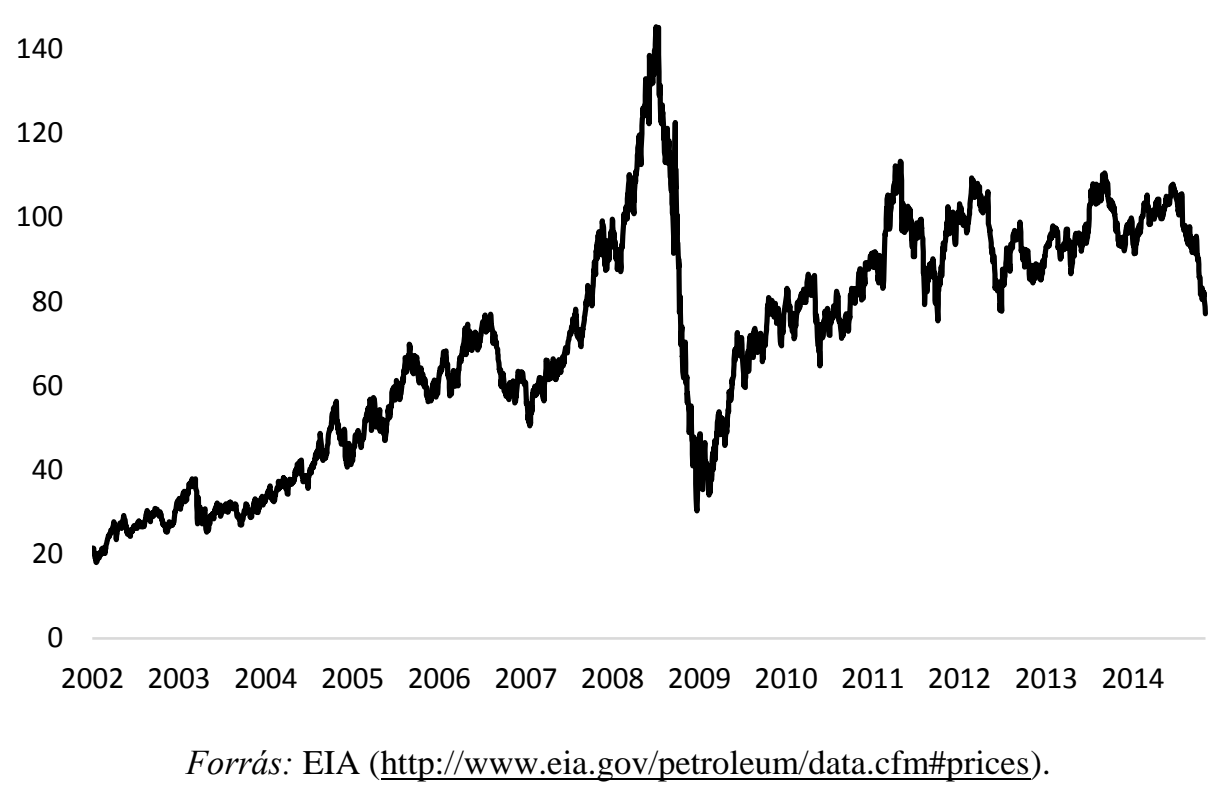

35. ábra: Benzin és fütőolaj spreadek (2002.01.02-2014.11.04.)

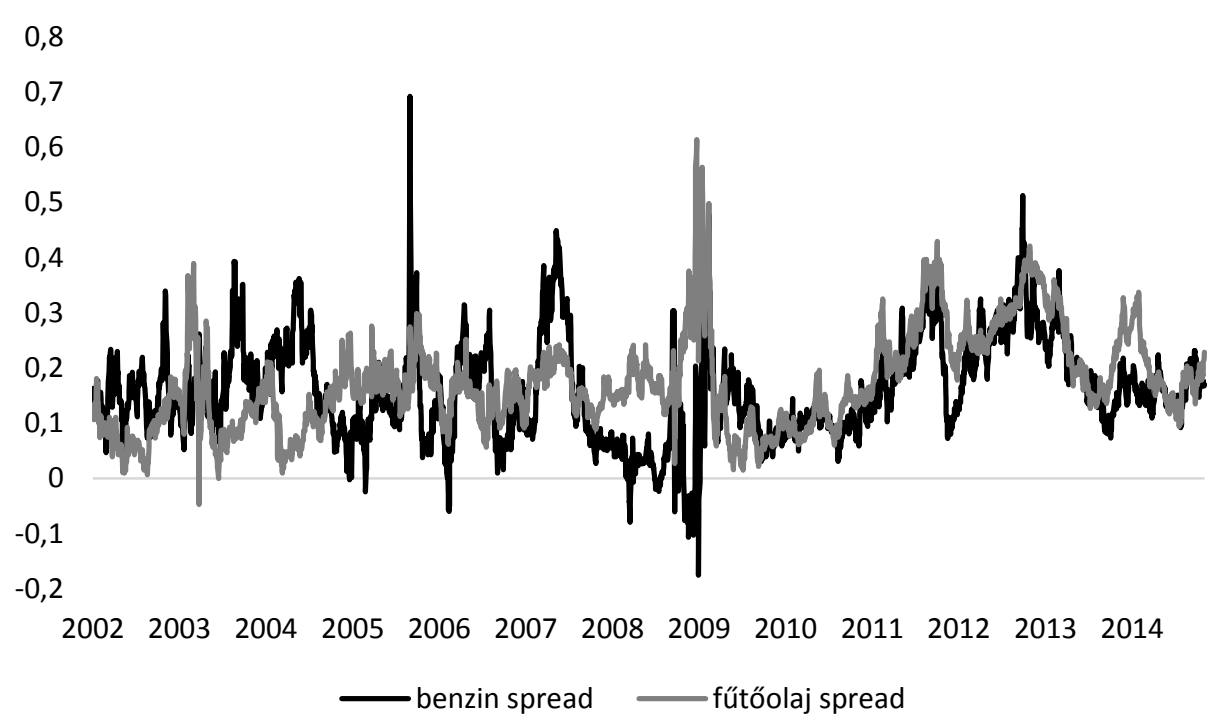

Forrás: EIA (http://www.eia.gov/petroleum/data.cfm\#prices).

A 6. táblázatban az egyes változók dlog idősorainak leíró statisztikái láthatók a teljes időszakra vonatkozóan. Minden esetben nulla közelében vannak az átlag és medián értékek, és az interkvartilis terjedelem (ahová az értékek középső 50\%-a esik) is kivétel 
nélkül 3 százalékpont alatt marad. Ugyanakkor alkalmanként előfordulnak jelentős, változótól függően 10-25\%-os elmozdulások is.

6. táblázat: A dlog idősorok leíró statisztikái (2002.01.02-2014.11.04.)

\begin{tabular}{|c|c|c|c|c|c|c|c|}
\hline & $\begin{array}{c}\text { WTI } \\
\text { spot }\end{array}$ & Benzin & Fütőolaj & WTI F1 & WTI F2 & WTI F3 & WTI F4 \\
\hline Átlag & 0,0004 & 0,0004 & 0,0004 & 0,0004 & 0,0004 & 0,0004 & 0,0004 \\
\hline Medián & 0,0010 & 0,0014 & 0,0000 & 0,0010 & 0,0009 & 0,0009 & 0,0010 \\
\hline Szórás & 0,0233 & 0,0269 & 0,0215 & 0,0229 & 0,0210 & 0,0201 & 0,0196 \\
\hline Minimum & $-0,1519$ & $-0,1789$ & $-0,1104$ & $-0,1307$ & $-0,1143$ & $-0,1038$ & $-0,1260$ \\
\hline Maximum & 0,1641 & 0,2351 & 0,1102 & 0,1641 & 0,1278 & 0,1212 & 0,1147 \\
\hline Terjedelem & 0,3160 & 0,4140 & 0,2206 & 0,2948 & 0,2421 & 0,2250 & 0,2407 \\
\hline 25. perc. & $-0,0114$ & $-0,0139$ & $-0,0115$ & $-0,0117$ & $-0,0111$ & $-0,0106$ & $-0,0101$ \\
\hline 75. perc. & 0,0128 & 0,0151 & 0,0128 & 0,0126 & 0,0120 & 0,0115 & 0,0110 \\
\hline IQR & 0,0243 & 0,0290 & 0,0244 & 0,0243 & 0,0231 & 0,0221 & 0,0211 \\
\hline
\end{tabular}

A spread idősorok hasonló értékeit a 7. táblázat mutatja. A benzin és a fütőolaj esetén tapasztalt többletek abból erednek, hogy nem ugyanannak a terméknek a két (spot és futures) árai kerülnek összevetésre, így a spread mutatók egyensúlyi értéke - feltéve, hogy egyáltalán létezik ilyen - a pozitív tartományba esik. Érdekes megfigyelés továbbá, hogy a futures árak esetén a horizont (hány „hónapos” határidő) növekedésével párhuzamosan (de nem arányosan) távolodnak az eloszlás kitüntetett pontjai a nullától, így az eloszlás terjedelme is folyamatosan növekszik. Ez megfelel az előzetes várakozásoknak, hiszen minél távolabb tekintünk a jövőbe, annál nagyobb elmozdulások lehetségesek. Az is látható azonban, hogy az 1 ill. 2 „hónapos” futures árak között van a legnagyobb ugrás, utána a változás üteme mérséklődik. 
7. táblázat: A spread [ln(változó)-ln(WTI spot)] idősorok leíró statisztikái (2002.01.022014.11.04.)

\begin{tabular}{|c|c|c|c|c|c|c|}
\hline & Benzin & Fütőolaj & WTI F1 & WTI F2 & WTI F3 & WTI F4 \\
\hline Átlag & 0,1590 & 0,1730 & 0,0007 & 0,0054 & 0,0073 & 0,0074 \\
\hline Medián & 0,1490 & 0,1604 & 0,0001 & 0,0047 & 0,0079 & 0,0109 \\
\hline Szórás & 0,0909 & 0,0864 & 0,0100 & 0,0244 & 0,0370 & 0,0474 \\
\hline Minimum & $-0,1755$ & $-0,0472$ & $-0,1780$ & $-0,2335$ & $-0,2488$ & $-0,2615$ \\
\hline Maximum & 0,6922 & 0,6139 & 0,2526 & 0,3279 & 0,3705 & 0,4028 \\
\hline Terjedelem & 0,8677 & 0,6611 & 0,4306 & 0,5614 & 0,6193 & 0,6643 \\
\hline 25. perc. & 0,0963 & 0,1117 & $-0,0006$ & $-0,0048$ & $-0,0132$ & $-0,0220$ \\
\hline 75. perc. & 0,2112 & 0,2180 & 0,0015 & 0,0124 & 0,0215 & 0,0285 \\
\hline IQR & 0,1148 & 0,1063 & 0,0022 & 0,0172 & 0,0347 & 0,0504 \\
\hline
\end{tabular}

Forrás: saját szerkesztés.

\section{IV.4. Eredmények}

A különböző eljárások teljesítményének mérésére az alábbi benchmark-okat használom:

- RMSE: eltolás nélküli véletlen bolyongás

- MAE: eltolásos véletlen bolyongás

- találati arány: eltolásos véletlen bolyongás, ami mindig növekedést jelez elöre, de abban az esetben, ha ez 50\% alatti eredményt ad (ez történik 2014-ben), akkor a szigorúbb 50\%-os küszöböt alkalmazom

- profit: a „,buy and hold” stratégia, tehát az éves hozam az időszak végén és elején fennálló árak hányadosából számolódik (mivel 2012-ben és 2014-ben ez negatív hozamot eredményezne, ezekben az években a 0\%-os értéket használom viszonyítási alapnak)

A küszöbszintek megválasztása az elörejelzés jósága alapján történt. A teljes vizsgált 2011-2014-es - periódusban RMSE tekintetében az eltolás nélküli, míg az átlagos abszolút hibánál az eltolásos véletlen bolyongás teljesített jobban. Mivel 2014 kivételével az árváltozás iránya az esetek legalább felében pozitív volt, ezért itt a benchmark a mindig növekedést elörejelző heurisztikus modell lett, aminek eredménye egybeesik az eltolásos véletlen bolyongással. A profitmutatónál a szokásos „,buy and hold” stratégiával dolgozom, de mivel ez két évben $(2012,2014)$ is negatív hozamot eredményez, ezért egy 
szigorúbb korlátot használok, és az ominózus periódusokban 0\%-ra állítom a küszöbszintet. A viszonyítási alapok konkrét értékeit a 8-11. táblázatok mutatják.

8. táblázat: RMSE benchmark értékek (eltolás nélküli véletlen bolyongás, USD/hordó)

\begin{tabular}{|c|c|c|c|c|}
\hline & $\mathbf{2 0 1 1}$ & $\mathbf{2 0 1 2}$ & $\mathbf{2 0 1 3}$ & $\mathbf{2 0 1 4}$ \\
\hline $\mathbf{1}$ napos & 2,0207 & 1,4897 & 1,1291 & 1,2359 \\
\hline $\mathbf{2}$ napos & 2,9043 & 1,9518 & 1,6409 & 1,6548 \\
\hline 3 napos & 3,5494 & 2,3409 & 2,0658 & 1,9636 \\
\hline
\end{tabular}

Forrás: saját szerkesztés.

9. táblázat: MAE benchmark értékek (véletlen bolyongás eltolással, USD/hordó)

\begin{tabular}{|c|c|c|c|c|}
\hline & $\mathbf{2 0 1 1}$ & $\mathbf{2 0 1 2}$ & $\mathbf{2 0 1 3}$ & $\mathbf{2 0 1 4}$ \\
\hline $\mathbf{1}$ napos & 1,5038 & 1,1155 & 0,8911 & 0,8929 \\
\hline $\mathbf{2}$ napos & 2,1716 & 1,5016 & 1,2592 & 1,2269 \\
\hline $\mathbf{3}$ napos & 2,7825 & 1,7523 & 1,6315 & 1,5122 \\
\hline
\end{tabular}

10. táblázat: Találati arány (DA) benchmark értékek (véletlen bolyongás eltolással, kivéve 2014)

\begin{tabular}{|c|c|c|c|c|}
\hline & $\mathbf{2 0 1 1}$ & $\mathbf{2 0 1 2}$ & $\mathbf{2 0 1 3}$ & $\mathbf{2 0 1 4}$ \\
\hline $\mathbf{1}$ napos & $52,78 \%$ & $53,17 \%$ & $52,78 \%$ & $50,00 \%$ \\
\hline $\mathbf{2}$ napos & $52,38 \%$ & $50,00 \%$ & $53,97 \%$ & $50,00 \%$ \\
\hline 3 napos & $56,35 \%$ & $52,38 \%$ & $53,17 \%$ & $50,00 \%$ \\
\hline \multicolumn{4}{|c}{ Forrás: saját szerkesztés. }
\end{tabular}

11. táblázat: Profit benchmark értékek („buy and hold”, kivéve 2012 és 2014)

\begin{tabular}{|c|c|c|c|c|}
\hline & $\mathbf{2 0 1 1}$ & $\mathbf{2 0 1 2}$ & $\mathbf{2 0 1 3}$ & $\mathbf{2 0 1 4}$ \\
\hline Éves hozam & $8,15 \%$ & $0,00 \%$ & $6,90 \%$ & $0,00 \%$ \\
\hline
\end{tabular}

Forrás: saját szerkesztés.

A 12. táblázatban az egyes cellák azt fejezik ki, hogy az oszlop szerinti évben, a sor szerinti hibamutató/előrejelzési horizont pár mentén a vizsgált modellek hány százaléka adott a vonatkozó benchmark-nál jobb eredményt. Megjegyzendő, hogy míg az 1 napos találati arány és a profit mutatók esetén összesen 1654 elörejelzés kerül az elemzésbe, addig a többi esetben csupán 404 modellel dolgozom. A különbséget az 1 napos irányelőrejelzésre épített LPM, logit, SVM és neurális háló modellek okozzák. Az eredményekből megállapítható, hogy az egyes módszerek relatív - a benchmark-hoz 
viszonyított - teljesítménye mind az előrejelzési horizont (1, 2 vagy 3 napos előrejelzés), mind a vizsgált időszak (év) tekintetében erősen volatilis. Az 1 napos projekciók RMSE értékei például évtől függően az esetek 2,5-48\%-ában haladják meg a küszöbszintet, és hasonló nagyságrendű eltérések tapasztalhatók MAE és találati arány tekintetében is. Az előrejelzési horizont változása is nagyban befolyásolja a felülteljesítő modellek arányát: RMSE és MAE mellett is igaz, hogy míg 2013-ban az előrejelzési horizont növekedésével párhuzamosan bővült a benchmark-ot legyőző modellek hányada, ez a „trend” 2014-ben megfordult.

12. táblázat: A benchmark értékeknél jobban teljesítő modellek aránya az összes modellhez képest

\begin{tabular}{|c|c|c|c|c|c|}
\hline \multicolumn{2}{|c|}{} & $\mathbf{2 0 1 1}$ & $\mathbf{2 0 1 2}$ & $\mathbf{2 0 1 3}$ & $\mathbf{2 0 1 4}$ \\
\hline \multirow{3}{*}{ RMSE } & I napos & $2,72 \%$ & $9,90 \%$ & $5,45 \%$ & $48,27 \%$ \\
\cline { 2 - 6 } & 2 napos & $2,72 \%$ & $0,99 \%$ & $14,11 \%$ & $33,91 \%$ \\
\cline { 2 - 6 } & 3 napos & $12,13 \%$ & $0,00 \%$ & $36,39 \%$ & $23,76 \%$ \\
\hline \multirow{3}{*}{ MAE } & I napos & $11,88 \%$ & $15,59 \%$ & $9,16 \%$ & $53,22 \%$ \\
\cline { 2 - 6 } & 2 napos & $4,95 \%$ & $23,27 \%$ & $16,09 \%$ & $57,43 \%$ \\
\cline { 2 - 6 } & 3 napos & $58,66 \%$ & $3,22 \%$ & $44,80 \%$ & $26,73 \%$ \\
\hline \multirow{3}{*}{ DA } & I napos & $16,38 \%$ & $16,26 \%$ & $45,53 \%$ & $82,04 \%$ \\
\cline { 2 - 6 } & 2 napos & $55,94 \%$ & $68,07 \%$ & $13,61 \%$ & $63,12 \%$ \\
\cline { 2 - 6 } & 3 napos & $34,16 \%$ & $5,20 \%$ & $9,90 \%$ & $29,70 \%$ \\
\hline PROFIT & & $47,28 \%$ & $26,54 \%$ & $53,39 \%$ & $13,72 \%$ \\
\hline
\end{tabular}

Forrás: saját szerkesztés.

Az eredmények alapján tehát kijelenthető, hogy a legtöbb modell relatív teljesítménye az előrejelzési horizont és a vizsgált periódus függvényében változik. Kérdés azonban, hogy létezik-e a modelleknek olyan szük részhalmaza, amely a többséggel ellentétben mentes az efféle robusztusságbeli hiányosságoktól, és képes folyamatosan legyőzni a benchmarkot. A 13. táblázat elemei mutatják, hogy a sor szerinti hibamutató/előrejelzési horizont pár tekintetében a modellek hány százaléka teljesített jobban 0, 1, 2, 3 ill. 4 alkalommal (évben) a heurisztikus eljárásnál. Az RMSE benchmark-ot - föleg a 2012-es kivetítések pontatlansága miatt - egyetlen módszer sem tudta minden évben felülteljesíteni, és három alkalommal is csak egy meglehetősen szük körük (1-8\%) volt rá képes. A nagy eltéréseket kevésbé büntető MAE mutatónál már valamivel jobb a helyzet, de itt is csak a 2, illetve 3 napos elörejelzéseknél sikerült néhány olyan modellt találni, amely minden évben 
felülteljesített (az összes modell 0,5-1,5\%-a). Találati arány esetén ez az érték előrejelzési horizonttól függően 0-2 százalék, míg a profitmutatónál 1,15\%.

13. táblázat: A benchmark értékeknél 0, 1, 2, 3 ill. 4 alkalommal (évben) is jobban teljesítő modellek aránya az összes modellen belül

\begin{tabular}{|c|c|c|c|c|c|c|}
\hline \multicolumn{2}{|c|}{} & $\mathbf{0 x}$ & $\mathbf{1 x}$ & $\mathbf{2 x}$ & $\mathbf{3 x}$ & $\mathbf{4 x}$ \\
\hline \multirow{3}{*}{ RMSE } & 1 napos & $44,06 \%$ & $46,78 \%$ & $7,92 \%$ & $1,24 \%$ & $0,00 \%$ \\
\cline { 2 - 7 } & 2 napos & $61,63 \%$ & $26,98 \%$ & $9,41 \%$ & $1,98 \%$ & $0,00 \%$ \\
\cline { 2 - 7 } & 3 napos & $57,18 \%$ & $21,78 \%$ & $12,62 \%$ & $8,42 \%$ & $0,00 \%$ \\
\hline \multirow{3}{*}{ MAE } & 1 napos & $39,60 \%$ & $39,36 \%$ & $12,62 \%$ & $8,42 \%$ & $0,00 \%$ \\
\cline { 2 - 7 } & 2 napos & $34,16 \%$ & $38,86 \%$ & $18,56 \%$ & $7,92 \%$ & $0,50 \%$ \\
\cline { 2 - 7 } & 3 napos & $20,79 \%$ & $38,37 \%$ & $28,96 \%$ & $10,40 \%$ & $1,49 \%$ \\
\hline \multirow{3}{*}{ DA } & 1 napos & $9,13 \%$ & $32,35 \%$ & $48,79 \%$ & $8,65 \%$ & $1,09 \%$ \\
\cline { 2 - 7 } & 2 napos & $2,48 \%$ & $23,02 \%$ & $48,02 \%$ & $24,26 \%$ & $2,23 \%$ \\
\cline { 2 - 7 } & 3 napos & $40,35 \%$ & $41,58 \%$ & $16,83 \%$ & $1,24 \%$ & $0,00 \%$ \\
\hline \multirow{2}{*}{ PROFIT } & & $13,18 \%$ & $43,53 \%$ & $33,62 \%$ & $8,52 \%$ & $1,15 \%$ \\
\hline
\end{tabular}

Forrás: saját szerkesztés.

Bizonyos esetekben tehát léteznek olyan eljárások, amelyek tartósan elérik/meghaladják a küszöbszintet. További kérdés, mennyire stabil e halmaz az előrejelzési horizont dimenziójában, azaz jellemző-e, hogy az 1 napos viszonylatban legtöbbször felülteljesítő modell 2 és 3 napos kivetítésnél is megőrzi e kedvező tulajdonságát. Ennek eldöntéséhez a 14. táblázat nyújt segítséget, amelynek elemei azt fejezik ki, hogy az oszlop szerinti mutató esetén hány modell esik a benchmark-ot legtöbbször legyőzők halmazába 1, 2 és 3 napos projekciónál, illetve mekkora e halmazok metszete.

14. táblázat: A benchmark értékeknél a legtöbb alkalommal jobban teljesítő modellek halmazának közös része

\begin{tabular}{|c|c|c|c|c|c|c|c|c|c|}
\hline & \multicolumn{3}{|c|}{ RMSE } & \multicolumn{3}{c|}{ MAE } & \multicolumn{3}{c|}{ DA } \\
\cline { 2 - 10 } & 1 napos & 2 napos & 3 napos & 1 napos & 2 napos & 3 napos & 1 napos & 2 napos & 3 napos \\
\hline 1 napos & 5 & 0 & 3 & 34 & 2 & 2 & 18 & 0 & 0 \\
\hline 2 napos & - & 8 & 8 & - & 2 & 2 & - & 9 & 0 \\
\hline 3 napos & - & - & 34 & - & - & 6 & - & - & 5 \\
\hline
\end{tabular}

Forrás: saját szerkesztés. 
RMSE-nél például 5 eljárás esik a legjobb 1 napos előrejelzők csoportjába (kivétel nélkül 5 késleltetést alkalmazó ARX modellek, amelyek a futures és a spot árak közti spread értékeket használják), míg hosszabb távon 8 (2 napos) és 34 (3 napos) modell tartozik ugyanebbe a halmazba. Érdekes megfigyelés, hogy kivétel nélkül futures árakat használó ARX spread modellekről van szó, azaz RMSE tekintetében jellemzően a határidős áraktól vett eltérés bevonásával javítható az előrejelzés pontossága. Ugyanakkor az előrejelzési horizonttól függően változik e modellek köre: az 1 és 2 napos kivetítéseknek nincs közös részhalmaza, de a 2 napos távlatban legjobb modellek kivétel nélkül a 3 napos felülteljesítők kategóriájába esnek, azaz a 2 nap alatt megszerzett „előny” a következő 24 órában is kitart. Az eltolás nélküli véletlen bolyongáshoz képest egyébként nem túl nagy a javulás mértéke, jellemzően 1\% alatt marad a csökkenés, ami alól csak a 2014-es év jelent kivételt, amikor a negatív trend miatt könnyebb megverni a változatlan árak kivetítését (akár 2-3\%-kal is). Ennek tudatában nem meglepő, hogy az utolsó időszakot leszámítva a benchmark és a modellalapú előrejelzések „,azonosságának” nullhipotézise csak ritkán utasítható $\mathrm{el}^{84}$.

MAE esetén a benzin spread-et használó ARX eljárások jelentik a három halmaz közös részét ( 1 ill. 2 késleltetéssel $)^{85}$, és továbbra is jellemző, hogy a legjobbak közé kevés kivételtől eltekintve ARX spread modellek kerültek, de míg RMSE-nél kizárólag a határidős árak szerepeltek, itt már többször előjönnek a különböző olajszármazékokat használó eljárások. Ez arra enged következtetni, hogy az olajszármazékok és a WTI spot árak különbségét használó elörejelzések relatíve gyakran vétettek nagy hibát. Ez külünösen a 2014-es évre igaz, ahol a trendforduló utáni csökkenő árakat a futures modellek sokkal jobban le tudták követni: míg a 2011-2013-as időszakban az olajszármazék spread-re építő ARX becslések DA mutatóinak átlaga, mediánja és 90. percentilise szinte minden év/elörejelzési horizont pár esetén magasabb volt, addig a 2014-es évben jóval a futures csoport hasonló mutatói alá estek (lásd a 15. táblázatot), az ezzel járó nagyobb előrejelzési hibák következtében pedig az RMSE értékek is megugrottak. Mivel az első három évben az olajszármazékos csoport jobb találati arányai

\footnotetext{
${ }^{84}$ A tesztelés során Clark és West [2006] eljárását alkalmaztam, ahol a nullhipotézis szerint a két modell által adott elörejelzések négyzetes hibáinak különbsége várható értékben minden nap nulla. A részletes eredmények megtalálhatóak a Függelékben, a 23-25. táblázatokban.

${ }^{85}$ Ugyanakkor az eltolásos véletlen bolyongáshoz képest minimális a javulás mértéke. Sosem haladja meg az 1\%-ot, és a Diebold-Mariano teszthez (Diebold és Mariano [1995]) is végig 10\% feletti p-értékek tartoznak. A DM teszt nullhipotézise szerint a két modell által adott elörejelzések abszolút hibáinak különbsége várható értékben minden napon nullával egyenlö. A részletes eredmények megtalálhatóak a Függelékben, a 26-28. táblázatokban.
} 
ellenére is jellemzőbb volt a magasabb RMSE mutató, gyanítható, hogy a nagyobb előrejelzési hibák eleve gyakrabban előfordulnak ebben a körben, a trendtörés pedig csak ráerősített e tulajdonságra. Bár konkrét bizonyíték nincs rá, könnyen elképzelhető, hogy a futures árak gyorsabban reagálnak a megjelenő hírekre, így felhasználásukkal csökkenthető a nagy elörejelzési hibák előfordulásának valószínűsége.

15. táblázat: Az olajszármazék és futures spread modellek találati arányainak jellemző értékei (átlag, medián, 90. percentilis)

\begin{tabular}{|c|c|c|c|c|c|c|c|c|c|}
\hline & \multicolumn{2}{|c|}{2011} & \multicolumn{2}{|c|}{2012} & \multicolumn{2}{|c|}{2013} & \multicolumn{2}{|c|}{2014} \\
\hline & & Olajsz. & Futures & Olajsz. & Futures & Olajsz. & Futures & Olajsz. & Futures \\
\hline \multirow{3}{*}{$\begin{array}{c}1 \\
\text { napos }\end{array}$} & Átlag & $52,78 \%$ & $51,65 \%$ & $51,87 \%$ & $49,79 \%$ & $50,64 \%$ & $49,86 \%$ & $51,41 \%$ & $55,65 \%$ \\
\hline & Medián & $51,98 \%$ & $51,19 \%$ & $52,38 \%$ & $49,60 \%$ & $50,79 \%$ & $49,60 \%$ & $51,18 \%$ & $55,92 \%$ \\
\hline & 90.p. & $56,75 \%$ & $53,57 \%$ & $53,57 \%$ & $51,75 \%$ & $52,86 \%$ & $53,21 \%$ & $54,50 \%$ & $58,34 \%$ \\
\hline \multirow{3}{*}{$\begin{array}{c}2 \\
\text { napos }\end{array}$} & Átlag & $55,11 \%$ & $53,48 \%$ & $51,96 \%$ & $50,70 \%$ & $51,51 \%$ & $49,67 \%$ & $49,28 \%$ & $53,89 \%$ \\
\hline & Medián & $55,95 \%$ & $54,17 \%$ & $52,18 \%$ & $50,60 \%$ & $51,39 \%$ & $48,81 \%$ & $48,82 \%$ & $53,79 \%$ \\
\hline & 90. $p$. & $58,73 \%$ & $57,14 \%$ & $53,97 \%$ & $53,17 \%$ & $55,16 \%$ & $53,21 \%$ & $53,55 \%$ & $55,92 \%$ \\
\hline \multirow{3}{*}{$\begin{array}{c}3 \\
\text { napos }\end{array}$} & Átlag & $57,29 \%$ & $55,63 \%$ & $51,00 \%$ & $49,58 \%$ & $50,99 \%$ & $50,56 \%$ & $46,41 \%$ & $52,13 \%$ \\
\hline & Medián & $57,94 \%$ & $56,35 \%$ & $51,59 \%$ & $49,80 \%$ & $50,40 \%$ & $50,79 \%$ & $46,21 \%$ & $52,37 \%$ \\
\hline & 90.p. & $59,17 \%$ & $57,58 \%$ & $52,78 \%$ & $52,38 \%$ & $55,56 \%$ & $52,38 \%$ & $48,39 \%$ & $54,98 \%$ \\
\hline
\end{tabular}

Forrás: saját szerkesztés.

Megjegyzés: A kiemelés jelzi azokat az eseteket, amikor a futures modellek bírnak magasabb DA értékkel.

Visszatérve a 14. táblázathoz, megállapítható, hogy találati arány szempontjából az 1 napos kivetítéseknél túlnyomórészt bináris függő változós modellek kerülnek a halmazba, és az SVM révén itt már a gépi tanulás is képes a folyamatos felülteljesítésre. Mind itt, mind a 2-3 napos projekcióknál jellemző, hogy a modellek között egyaránt van olajszármazék vagy határidős árat (esetleg mindkettőt) használó eljárás, azaz nincs olyan magyarázó változó halmaz, amely előrejelzés tekintetében dominálná a másikat. Ennek következtében a három halmaz metszete üres, ami abban a tekintetben nem meglepetés, hogy az 1 napos irány-előrejelzéseknél a korábbinál jóval bővebb, körülbelül négyszer akkora elemszámú csoportból lettek kiválogatva a módszerek. Megjegyzendő továbbá, hogy minden év/elörejelzési horizont pár esetén valahol 55-60\% környékén található a legnagyobb találati aránnyal bíró modell, azaz a korábban hivatkozott (Haidar és 
Kulkarni [2009], Yu et al. [2008]) tanulmányokban található 80\% feletti értékek valós idejű elörejelzésnél nem tarthatóak hosszú távon ${ }^{86}$.

Az egyes bináris függő változós modellekhez tartozó, éveken át a viszonyítási alap fölött teljesítő irány-előrejelzések pontossága alighanem hozzájárul ahhoz, hogy döntően e módszerekből kerülnek ki a legnagyobb profitot eredményező eljárások is. Bár az összes vizsgált módszer mintegy 2/3-a bináris függő változót használ, a legjobban teljesítők között ennél jóval nagyobb az arányuk (84\%), csak elvétve találni egy-két folytonos függő változójú modellt. Itt ugyanakkor érdemes kitérni a „legjobban teljesítő” definíciójára. Ha ugyanis az eddigiekhez hasonlóan a teljesítményt abban mérjük, hogy hányszor tudta felülmúlni az elörejelzés a benchmark-ot, akkor a jó relatív teljesítmény robusztusságáról beszélünk, míg egy kereskedőnek adott esetben fontosabb lehet a hosszú távon, tehát a teljes időszak során realizált profit. Az eredményekből kitünik, hogy a két halmaz nem esik egybe: míg a folyamatos felülteljesítők között elsősorban bináris függő változós ökonometriai (LPM és logit) modellek szerepelnek, amelyek mind az olajszármazékok spot, mind az olaj határidős árait felhasználják, addig a közel 4 év egésze alatt begyüjtött legmagasabb hozamok az SVM eljáráshoz tartoznak. A 16. táblázatból leolvasható, hogy a futures spread-eket használó SVM-ek akár 70-80\%-os profitot is hozhattak, ám egyikük sem fér bele az eddig használt „legjobb modellek” definíciójába. A 18 késleltetéssel dolgozó, „2 hónapos” futures spread-et használó SVM például hiába eredményezi a legnagyobb bővülést, ennek felhalmozása döntően az időszak elejére esik, és az utolsó két évben már nem éri el a küszöbszintet ${ }^{87}$. Ez az eredmény megerősíti azt a következtetést, amely szerint az eljárások rangsora attól függ, hogy az időszak, előrejelzési horizont és hibamutató „,paramétereknek” milyen kombinációját használjuk.

\footnotetext{
${ }^{86}$ Annál is inkább, mivel a legjobb modellek halmazába egyetlen olyan eljárás sem került, amelynél mind a 4 évben el lehetett volna utasítani a Pesaran-Timmermann teszt nullhipotézisét (Pesaran és Timmermann [1992]). A részletes eredmények megtalálhatóak a Függelékben, a 29-31. táblázatokban.

${ }^{87}$ Míg 2011-ben közel 65\%-os többletet eredményezett, utána rendre 6,5\%, 5,3\% ill. -2,3\% volt a modell hozadéka.
} 
16. táblázat: A teljes előrejelzési periódus (2011-2014) alatt a 20 legmagasabb profitmutatót eredményező modell

\begin{tabular}{|c|c|c|}
\hline Modell & Késleltetés & Profit (2011-2014) \\
\hline$S V M \_S \_F 2$ & 18 & $80,35 \%$ \\
\hline SVM_S_F3 & 18 & $76,38 \%$ \\
\hline LOGIT_D_MINDEN* & 10 & $72,79 \%$ \\
\hline LOGIT_D_MINDEN* & 12 & $70,48 \%$ \\
\hline SVM_S_F4 & 18 & $69,34 \%$ \\
\hline LOGIT_D_F1234* & 12 & $66,87 \%$ \\
\hline LOGIT_D_F1234* & 10 & $65,08 \%$ \\
\hline LOGIT_S_Fl & 5 & $63,07 \%$ \\
\hline LOGIT_D_MINDEN & 8 & $62,99 \%$ \\
\hline$L P M \_S \_F 1$ & 5 & $62,78 \%$ \\
\hline LPM_S_F1* & 4 & $62,44 \%$ \\
\hline LOGIT_S_F1* & 4 & $61,34 \%$ \\
\hline LPM_D_F1 & 9 & $60,67 \%$ \\
\hline LPM_D_MINDEN* & 11 & $60,34 \%$ \\
\hline LPM_D_F1234 & 9 & $60,28 \%$ \\
\hline$S V M \_S \_F 2$ & 5 & $60,20 \%$ \\
\hline LPM_D_MINDEN* & 12 & $60,20 \%$ \\
\hline LOGIT_D_MINDEN* & 19 & $59,55 \%$ \\
\hline LOGIT_D_F1234* & 9 & $59,08 \%$ \\
\hline LOGIT_S_F1 & 7 & $58,31 \%$ \\
\hline
\end{tabular}

Forrás: saját szerkesztés.

Megjegyzés: Az első oszlopban a modell neve (módszertan + típus ( $\mathrm{S}$ - spread, D - dlog) + magyarázó változók (FX - X „hónapos” futures, MINDEN - 4 futures ill. benzin és fütőolaj spot)), a másodikban a késleltetések száma (p) szerepel. A *-gal jelölt és félkövér betütípussal kiemelt modelleken alapuló kereskedési stratégiák mind a 4 év során a küszöbszintet meghaladó profitot eredményeztek.

Végül érdemes megvizsgálni az ökonometriai és gépi tanulásos modellek egymáshoz viszonyított teljesítményét. Az egyszerüség kedvéért az elemzés csupán az egyes csoportokra jellemző jósági mutatók medián értékeire fókuszál. A 17. táblázatban a gépi tanuláson alapuló modellekhez tartozó RMSE, MAE és DA hibaértékek mediánjainak, valamint az ökonometriai eljárások hasonló mutatóinak hányadosai szerepelnek. A hipotetikus profitfüggvény esetén a medián hozamok közti különbséget („gépi tanulás mínusz ökonometria") vizsgálom. Ennek megfelelően a 100\% alatti RMSE és MAE, illetve a $100 \%$ feletti DA, valamint a pozitív profit mutatók jelölik a gépi tanulás jobb 
medián teljesítményét (ezeket az eseteket a táblázatban is kiemeltem). Az eredmények alapján nem lehet egyértelmü összefüggést találni, hol az egyik, hol a másik csoport szerepel jobban. Ez rávilágít arra, hogy bár a gépi tanuláson alapuló modellek ritkán tudták elérni a kijelölt küszöbszinteket, medián teljesítményük még így sem maradt el az ökonometriai módszerekétől. Ezért a tanuló algoritmusok paramétereinek optimalizálása, a megfelelő késleltetési struktúra megtalálása, illetve a kalibrálás - jelenleg éves gyakoriságának növelése révén akár az is elképzelhető, hogy a hiányolt robusztusság elérhető.

17. táblázat: A gépi tanulásos modellek ökonometriai modellekhez mért relatív teljesítménye (mediánok hányadosa)

\begin{tabular}{|c|c|c|c|c|c|}
\hline & & $\mathbf{2 0 1 1}$ & $\mathbf{2 0 1 2}$ & $\mathbf{2 0 1 3}$ & $\mathbf{2 0 1 4}$ \\
\hline \multirow{3}{*}{ RMSE } & 1 napos & $\mathbf{9 9 , 6 6 \%}$ & $\mathbf{9 9 , 1 4 \%}$ & $\mathbf{9 9 , 6 1 \%}$ & $100,69 \%$ \\
\cline { 2 - 6 } & 2 napos & $100,08 \%$ & $100,64 \%$ & $\mathbf{9 9 , 8 3 \%}$ & $100,10 \%$ \\
\cline { 2 - 6 } & 3 napos & $100,01 \%$ & $100,20 \%$ & $100,12 \%$ & $\mathbf{9 9 , 4 1 \%}$ \\
\hline \multirow{3}{*}{ MAE } & 1 napos & $\mathbf{9 9 , 7 5 \%}$ & $\mathbf{9 9 , 0 1 \%}$ & $\mathbf{9 9 , 3 9 \%}$ & $100,84 \%$ \\
\cline { 2 - 6 } & 2 napos & $100,45 \%$ & $100,30 \%$ & $\mathbf{9 9 , 8 9 \%}$ & $100,88 \%$ \\
\cline { 2 - 6 } & 3 napos & $100,06 \%$ & $100,13 \%$ & $100,27 \%$ & $\mathbf{9 9 , 3 9 \%}$ \\
\hline \multirow{3}{*}{ DA } & 1 napos & $99,22 \%$ & $\mathbf{1 0 0 , 7 8 \%}$ & $95,56 \%$ & $95,68 \%$ \\
\cline { 2 - 6 } & 2 napos & $94,43 \%$ & $98,12 \%$ & $\mathbf{1 0 2 , 1 1 \%}$ & $99,04 \%$ \\
\cline { 2 - 6 } & 3 napos & $96,37 \%$ & $\mathbf{1 0 3 , 4 1 \%}$ & $\mathbf{1 0 2 , 4 6 \%}$ & $\mathbf{1 0 4 , 0 0 \%}$ \\
\hline \multirow{2}{*}{ profit } & & $\mathbf{0 , 7 1 \%}$ & $-0,19 \%$ & $-4,99 \%$ & $-4,84 \%$ \\
\hline
\end{tabular}

Forrás: saját szerkesztés.

Megjegyzés: RMSE, MAE és DA esetén a medián hibamutatók hányadosa, profitnál a hozamok különbsége szerepel. Kiemelve szerepelnek azok az esetek, ahol a gépi tanuláson alapuló modellek jobb „medián” elörejelzőnek bizonyultak.

A fentiek ismeretében az alábbi konklúziók vonhatók le:

1) Függetlenül attól, hogy az időszak, előrejelzési horizont és hibamutató „paraméterek” milyen kombinációját alkalmazzuk, az olajszármazék spot ill. az olaj futures árak bevonásával javítható az előrejelzés pontossága. Míg RMSE tekintetében egyértelmüen a futures spread-ekre épülő modellek használata javallott, addig az átlagos abszolút hiba, a találati arány vagy a bemutatott hipotetikus profitfüggvény esetén mindkét változócsalád alkalmazható. 
2) Az ökonometriai modellek robusztusság tekintetében ugyan jobban teljesítenek a gépi tanulásnál, azonban összehasonlításuk több szempontból is problémás. Egyrészt a machine learning eljárásoknál évente csak egyszer frissülnek a modellek, másrészt a tanuló algoritmusok paramétereinek kioptimalizálása nem történt meg, azok egyetlen beállítás mellett futnak. Könnyen előfordulhat, hogy a megfelelő módosításokkal ez a modellcsalád is versenyképessé válna. Ugyanakkor már most is lehet olyan mutatót (profit) találni, amelynél az SVM kifejezetten jó teljesítményt nyújt (legalábbis a teljes időszak során elért hozamok tekintetében), ráadásul a gépi tanulásos modellek medián teljesítménye egyáltalán nem rosszabb az ökonometriai megközelítésekénél.

3) A legjobb modellek halmaza mind az elörejelzési horizont, mind a vizsgált időszak függvényében változik, és csak néhány olyan eljárás van, ami hosszabb távon végig felülteljesít. Mivel összesen 4 év vizsgálata történt meg, ezért elképzelhető, hogy ez csupán a véletlen müve, és hosszabb tesztelési mintával dolgozva már nem lennének képesek folyamatosan túlteljesíteni a küszöbszintet. Ennek azért is nagy az esélye, mert sem az RMSE, sem a MAE, sem pedig a DA mutatóknál nem volt olyan modell, ami minden évben szignifikánsan jobb lett volna a benchmark-nál.

4) Ebböl az is következik, hogy bár az eredmények alapján úgy tünik, lehetséges az egyszerű heurisztikus szabályoknál jobb modellt építeni, ennek időbeli robusztussága megkérdőjelezhető, és sosem lehetünk biztosak abban, hogy egy éveken át felülteljesítő modell a következő hónapokban/években is megőrzi e képességét.

\section{IV.5. Kiegészítés: előzetes szelekció alkalmazása}

$\mathrm{Az}$ eddig ismertetett megközelítés hátránya, hogy nincs lehetőség minden létező modell/input változó párnak a végigpróbálására, ugyanakkor léteznek olyan eljárások, amelyek előzetes szelekció révén segítenek kialakítani a változók halmazát és a modell késleltetési struktúráját. Az egyik az ún. ,stepwise” regresszió, ami szignifikancia alapján válogatja össze a jobb oldali változókat. Hátránya azonban, hogy idősorok előrejelzéséhez nem feltétlenül szükséges a bevont változók koefficienseinek 
szignifikanciája, és a szelekció során egyáltalán nem veszi figyelembe a predikciós teljesítményt. Azonban egy másik eljárás, a $\mathrm{LASSO}^{88}$ regresszió, már képes erre.

\section{IV.5.1. LASSO}

A módszer részleteinek ismertetésétől ezúttal eltekintek, arról bővebb leírás található Tibshirani [1996] munkájában. Az eredmények értelmezéséhez elég annyit tudni, hogy jelen esetben az alábbi optimalizálási feladat megoldása a cél:

$$
\min _{\beta_{0}, \beta_{1}, \ldots, \beta_{k}}\left[\frac{1}{2 n} \sum_{i=1}^{n}\left(y_{i}-\beta_{0}-\beta_{1} x_{1 i}-\ldots-\beta_{k} x_{k i}\right)^{2}+\lambda \sum_{j=1}^{k}\left|\beta_{j}\right|\right]
$$

Ahol $n$ a megfigyelések, míg $k$ a lehetséges jobb oldali változók száma. $\lambda$ paraméter nagysága a nem nulla koefficiensek „költségét” fejezi ki. Látható, hogy az eljárás a klasszikus legkisebb négyzetek módszerére épül ( $\lambda=0$ esetén egybeesik vele), de annak célfüggvényét egy plusz taggal bővíti ${ }^{89}$. Ennek révén az optimumban egy vagy akár több változó koefficiense is nulla lesz, így ezeket elhagyhatjuk az elemzésböl. Két dologra azonban érdemes figyelni. Egyrészt a változók mértékegységei a meredekségi paramétereken keresztül befolyásolják a kimenetet. Ezt a problémát sztenderdizálással tudjuk kiiktatni. A másik lehetséges buktató a $\lambda$ paraméter kalibrálása. Könnyen belátható, hogy minél nagyobb értéket vesz fel, a modell annál jobban bünteti a nullától eltérő koefficienseket, így egyre kevesebb változót hagy meg a folyamat végén. Mivel a cél a WTI spot árának minél pontosabb elörejelzése, $\lambda$ beállítását keresztvalidációval végzem. Ennek során az alábbi eljárást követem:

- a becslési mintát véletlenszerủen 10 egyenlő elemszámú részre bontom (az egyes részeknek nem kell összefüggő időszakokat alkotniuk)

- 100 különböző $\lambda$ értéket generálok, melyek mindegyikére lefuttatom a becslést

- adott $\lambda$ melletti optimalizáció valójában 10 becslést jelent: minden alkalommal csak a minta 90\%-ra becsülöm meg a paraméterek értékeit, a maradék 10\%-on

\footnotetext{
${ }^{88}$ Least Absolute Selection and Shrinkage Operator

${ }^{89}$ A LASSO az elasztikus hálók egy speciális esete. Ennek egy másik ismert formája a ridge regresszió, ami csupán annyiban különbözik a LASSO-tól, hogy a koefficiensek abszolút értéke helyett azok négyzetét teszi a célfüggvénybe. Ennek egyik következménye, hogy bár a kevésbé meghatározó változók paraméterei közel esnek nullához, az egyenlőség jellemzően nem fog teljesülni.
} 
pedig előrejelzést végzem a kapott modellel, és kiszámítom az ehhez tartozó átlagos négyzetes hiba (MSE) nagyságát

- a 10 futáshoz tartozó MSE értékeket átlagolom, az így kapott hibamutató lesz a kiértékelés alapja

- megkeresem azt a $\lambda_{\min }$ értéket, amely mellett a legkisebb az elörejelzés egyes részmintákon elkövetett átlagos négyzetes hibáinak átlaga

- azt a legnagyobb $\lambda$-t tekintem irányadónak, amire teljesül, hogy a hozzá tartozó hibamutató értéke legfeljebb egy standard hibányival haladja meg a $\lambda_{\min }$ melletti átlagos MSE-t ${ }^{90}$

- ezt követően a kiválasztott $\lambda$ mellett a teljes mintán elvégzem a becslést

- azon változók, amelyekhez nem nulla koefficienst rendel az algoritmus, bekerülnek az elörejelző modellekbe

Ahogy az utolsó pontból kiderül, a LASSO eljárást itt csupán az input változók szelekciójára, és nem a közvetlen előrejelzésre használom. A prognózisok készítése során az alábbi megközelítéssel dolgozom:

- a függő változó az olajár (kiinduló helyzethez viszonyítva 1, 2 ill. 3 napos) logaritmikus differenciája vagy iránya (pozitív elmozdulás esetén 1 , különben 0 )

- a potenciális input változók a WTI spot és futures, valamint az olajszármazékok azonnali áraiból számolt logaritmikus differenciák, illetve a spread változók késleltetett értékei (mindkét esetben legfeljebb 20 késleltetést megengedve)

- a változók sztenderdizált formában kerülnek a modellbe, kivéve, amikor az elmozdulás iránya a függő változó, ekkor ugyanis csak az input oldalra érvényes, hogy minden tag nulla várható értékü és egységnyi szórású valószínüségi változóként szerepel ${ }^{91}$

A korábbiakhoz képest tehát annyi az eltérés, hogy minden modellel 1-3 napos valós idejü kivetítést fogok végezni (nincs dinamikus előrejelzés), ahol az input változókat egy - az eddiginél bővebb - halmazból elöre kiszüröm. Összesen 12 modellt becsülök, melyeket

\footnotetext{
${ }^{90}$ Itt az MSE-hez tartozó standard hibáról van szó. Megjegyzendő továbbá, hogy az 1 napos irányelörejelzésre használt LASSOGLM-nél $\lambda_{\min }$-t használom, máskülönben csak egy konstans szerepelne az input változók között.

${ }^{91}$ Az irány elörejelzéséhez a LASSOGLM eljárással is elvégeztem a szelekciót, mégpedig standard logisztikus eloszlású hibatag feltevése mellett. A becslési eredmények legfeljebb minimális különbséget mutattak az „LPM-szerü” (szintén LASSOGLM) megközelítéstől, az esetek többségében a kiszürt változók halmaza megegyezett.
} 
a már ismertetett benchmarkokhoz viszonyítok. A modellek input változóit minden előrejelzési év elején LASSO-val választom ki, majd egész évben (2011, 2012, 2013 vagy 2014) ezekkel a változókkal töltöm fel őket. Az ár előrejelzéseknél csak a sima LASSO, míg az iránynál a LASSOGLM (bináris függő változós eset) által megjelölt változóhalmazzal is elvégzem az elemzést.

Ár elörejelzése

Az árak 1-3 napos előrejelzésére OLS-t és neurális hálót használok. OLS esetén minden egyes nap újrakalibrálom a modellt, és a frissített paraméterek mellett végzem el a projekciót. Neurális hálóknál továbbra is évenkénti újrabecsléssel dolgozom, és nagyrészt minden korábban ismertetett beállítást megtartok. Az egyetlen eltérés, hogy nem 50, hanem 200 szimulációt futtatok, azoknak az olajár logaritmikus differenciájára vonatkozó előrejelzéseit átlagolom, majd ebből nyerem ki a WTI jövőbeli árára vonatkozó predikciót.

Irány elörejelzése

Az utolsó ismert árhoz viszonyított változás irányának előrejelzéséhez évente és naponta frissülő paraméterű modelleket egyaránt használok. Az LPM és a logit modelleket minden nap, a neurális hálókat viszont évente csak egyszer becsülöm újra ${ }^{92}$. Az SVM-et mind napi, mind éves gyakoriságú frissítés mellett futtatom. Ez összesen 5 modellt jelentene az egyes elörejelzési horizontokon (1, 2 ill. 3 napos kivetítéseknél), ugyanakkor minden esetben kétféle változóhalmazzal dolgozom. Egyszer az árváltozásra felírt LASSO, egyszer pedig az annak irányára fókuszáló LASSOGLM által leválogatott idősorokat használom fel.

\footnotetext{
92 Itt is 200 szimulációt futtatok, majd többségi elv alapján határozom meg a modell elörejelzését: akkor és csak akkor várok növekedést, ha legalább 101 alkalommal emelkedő árat prognosztizál a neurális háló. Az optimalizáláshoz minden esetben a Levenberg-Marquardt eljárást használom.
} 


\section{IV.5.2. Eredmények}

A szelekciós eljárások során a futures árak dlog és spread transzformációinak késleltetett értékei kerültek relatív túlsúlyba, és különösen a legközelebbi lejárat („,következő havi termék") volt az, ami gyakran ment át a szürőn.

A 18. táblázatban található az eljárások előrejelzési képességének kiértékelése a teljes 2011-2014-es időszakra vonatkozóan. Az ár előrejelzése mind az OLS, mind a neurális háló esetén a viszonyítási alapoknál (RMSE-nél RW, MAE-nál RWD) rosszabb illeszkedést mutat, ráadásul a Diebold-Mariano teszt szerint a szokásos szignifikancia szintek mellett elutasítható a két modell (RWD vs. OLS, illetve RWD vs. NN) prognózisaiból képzett abszolút különbségek nulla várható értékének nullhipotézise. A találati arány vizsgálatából több érdekes következtetést is levonhatunk:

- Általában javított az előrejelzés pontosságán, ha a szelekciós eljárás során már eleve az irány becslése került a fókuszba. Az SVM-et leszámítva majdnem minden modell/elörejelzési horizont pár esetén igaz, hogy a LASSOGLM használatával nagyobb hányadban sikerült eltalálni a változás irányát. Amikor ez nem történt meg, akkor is csak minimálisan maradt el a teljesítmény a sima LASSO-tól.

- Nem javított az SVM előrejelző képességén a sűrübb kalibrálás. A napi és az éves gyakoriságú frissítés mellett is nagyjából hasonló találati arányokat sikerült produkálni.

- A hipotetikus profitfüggvény szerint a „buy and hold” stratégia a közel 4 éves időszak alatt -11,9\%-os hozamot eredményezett volna. Bár az esetek többségében sikerült ennél nagyobb profitot realizálni, csupán a LASSOGLM használata segítségével lehetett érzékelhetően $0 \%$ fölé kerülni. Itt elsősorban az 1 napos kivetítésekben amúgy is jól teljesítő LPM, logit és neurális háló modelleket érdemes kiemelni, amelyek 33-37\%-os növekmény biztosítására voltak képesek. Igaz, ezzel az eredménnyel esélyük sem lett volna felférni a 16. táblázatban bemutatott „TOP20”-as listára. 
18. táblázat: Illeszkedési mutatók a teljes mintán (2011-2014)

\begin{tabular}{|c|c|c|c|c|c|c|c|c|c|c|c|}
\hline & \multicolumn{3}{|c|}{ RMSE } & \multicolumn{3}{|c|}{ MAE } & \multicolumn{3}{|c|}{ DA } & \multirow[t]{2}{*}{ PROFIT } \\
\hline & & D1 & D2 & D3 & D1 & D2 & D3 & D1 & D2 & D3 & \\
\hline \multirow{7}{*}{ ○ } & OLS & 1,55 & 2,18 & 2,65 & $1,15^{* * *}$ & $1,62 * * *$ & $2,00 * * *$ & $49,3 \%$ & $50,6 \%$ & $50,6 \%$ & $-15,7 \%$ \\
\hline & $\mathbf{N N}$ & 1,56 & 2,18 & 2,66 & $1,16 * * *$ & $1,61 * * *$ & $1,99 * *$ & $50,9 \%$ & $49,9 \%$ & $51,8 \%$ & $-6,7 \%$ \\
\hline & LPM & & & & & & & $51,6 \%$ & $49,2 \%$ & $52,4 \%$ & $-1,5 \%$ \\
\hline & logit & & & & & & & $51,3 \%$ & $49,9 \%$ & $53,1 \%$ & $-11,2 \%$ \\
\hline & NN_binary & & & & & & & $51,7 \%$ & $50,3 \%$ & $52,6 \%$ & $0,3 \%$ \\
\hline & SVM_Y & & & & & & & $49,7 \%$ & $50,1 \%$ & $52,0 \%$ & $-31,1 \%$ \\
\hline & SVM_D & & & & & & & $49,1 \%$ & $49,9 \%$ & $51,6 \%$ & $-19,4 \%$ \\
\hline \multirow{5}{*}{ 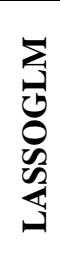 } & LPM & & & & & & & $53,6 \% *$ & $51,1 \%$ & $52,5 \%$ & $34,1 \%$ \\
\hline & logit & & & & & & & $53,7 \% *$ & $50,4 \%$ & $52,0 \%$ & $36,7 \%$ \\
\hline & NN_binary & & & & & & & $54,4 \%$ ** & $50,5 \%$ & $52,5 \%$ & $33,0 \%$ \\
\hline & SVM_Y & & & & & & & $49,8 \%$ & $48,1 \%$ & $47,4 \% *$ & $7,9 \%$ \\
\hline & SVM_D & & & & & & & $49,6 \%$ & $46,8 \%$ ** & $49,5 \%$ & $-12,8 \%$ \\
\hline
\end{tabular}

Forrás: saját szerkesztés.

Megjegyzés: A sötétszürke kiemelés jelzi a benchmarknál rosszabb (és a kapcsolódó teszt nullhipotézisét elutasító), míg a világosszürke hátterü, félkövér kiemelés az annál jobb teljesítményeket. A benchmarkoknál ezúttal nem használtam fel a 0 , illetve 50\%-os plusz megkötéseket. A ***, **, * jelölések mutatják, hogy a megfelelö teszt p-értéke 1, 5 vagy 10\% alatt van-e. Az alkalmazott tesztek: RMSE - Clark és West [2006], MAE - Diebold és Mariano [1995], DA - Pesaran és Timmermann [1992]. A táblázatban található rövidítések jelentése: OLS (legkisebb négyzetek módszere), NN (neurális háló), LPM (lineáris valószínűségi modell), logit (logisztikus regresszió), NN_binary (neurális háló bináris - 0/1 - függő változóval), SVM_Y (évente frissülő support vector machine), SVM_D (naponta frissülő support vector machine), DX (X napos elörejelzés).

Ami a robusztusságot illeti, a 32-35. táblázatok (Függelék) alapján a következő konklúziók vonhatók le:

- Az ár projekciója végig a bencmarknál nagyobb pontatlanság mellett valósult meg. Ez alól csupán a 2014-es 2 és 3 napos prognózisok MAE mutatói a kivételek, amikor a negatív trendet a folyton növekvő árak kivetítésénél némileg kisebb hibával sikerült előrejelezni, ám a Diebold-Mariano teszt nullhipotézise ekkor sem volt elutasítható.

- A találati arány előrejelzési időszak és horizont mentén egyaránt instabilnak bizonyult, a DA mutató értéke hol a benchmark fölött, hol az alatt teljesített, még úgy is, hogy ezúttal nem használtam az 50\%-os alsó küszöb megkötését. Így nem volt olyan modell/horizont pár, amely minden évben meghaladta volna a folyton az árak növekedésére számító stratégia teljesítményét. Megjegyzendő azonban, hogy a LASSOGLM-re épülő LPM, logit és bináris NN modellek a másnapi 
előrejelzésnél végig 50\% feletti találati aránnyal dolgoztak, és még ha el is maradtak a benchmark értéktöl, a különbség marginálisnak bizonyult. Ennek következménye a 18. táblázatban látható jó összteljesítmény.

- A ,buy and hold” stratégia hozamát csak a LASSOGLM-re épülö LPM és logit modellek tudták minden évben felülteljesíteni. Ugyanakkor a többi eljáráshoz hasonlóan ezek sem voltak képesek a 2012-es és a 2014-es években a pozitív tartományba lökni a profitmutatót, azaz a korábban használt 0\%-os megkötések mellett már ezek sem kerültek volna be a felülteljesítők halmazába.

Összegezve: a bemutatott szelekciós eljárásokkal sem sikerült olyan modellt építeni, ami konzisztensen a „legjobb modellek” halmazába került volna, a robusztusság hiánya ezúttal is fennáll. Természetesen a változók előzetes kiválasztására a LASSO-n kívül számos más módszer alkalmazható. Ezek között kiemelendő a „spike and slab” regresszió (Varian [2014]), illetve a Bayesi Strukturális Idősorok (BSTS) technikája (Scott és Varian [2013], [2014]), melyek a LASSO-hoz hasonlóan a gépi tanulás területéhez sorolandók. Ezek alkalmazása a kutatás egy potenciális továbblépési iránya lehet.

\section{IV.6. A fejezet összefoglalása}

A fejezet célja az olajár elörejelzésére használható módszerek egy igen széles körének bemutatása, a modellek teljesítőképességének összehasonlítása volt. A West Texas Intermediate (WTI) napi spot idősorát ökonometriai modellekkel és gépi tanulással jeleztem elöre, felhasználva a WTI futures ill. két olajszármazék (benzin és fütőolaj) spot referencia árait. Az elemzés során 1-3 napos valós idejű kivetítéseket generáltam a 2011 januárjától 2014 novemberéig terjedő tesztidőszakra, így a kapott eredmények megmutatják, milyen hatékonysággal müködtek a modellek a gyakorlatban. A kiértékelés során több alternatív mutatót (RMSE, MAE, találati arány, profit) is használtam, és a ,jó modellek" halmazát a mutatónként eltérő benchmark modell eredményeihez képest határoztam meg. Konklúzióm szerint a „legjobb” modellek halmaza erősen függ az elörejelzési horizont nagyságától, valamint a tesztidőszak és a hibamutató megválasztásától. A fundamentális változók bevonása ugyanakkor minden esetben preferált, a legtöbb évben felülteljesítő modellek köre szinte kivétel nélkül felhasználja az olaj futures és/vagy az olajszármazékok spot árait. Hogy pontosan milyen modellt, és milyen változókkal, késleltetési struktúrával érdemes használni, már a felhasználó 
konkrét céljától (a hibamutató megválasztásától) függ. Arra utaló eredmények is születtek, hogy bizonyos esetekben (a hipotetikus profitfüggvény maximalizálásakor) érdemes lehet átlépni az ökonometriai modellek határát, és a gépi tanulás eszközeihez folyamodni. Azonban itt is szembetünő a robusztusság hiánya, előfordul, hogy az egyik évben kiválóan teljesítő modell már a következő időszakban a heurisztikus szabálynál rosszabb előrejelzést produkál, és ezen az előzetes változószelekció sem segít. Figyelembe véve a legjobb modellek halmazának erős változékonyságát, nem szabad egyetlen eljárásra támaszkodni, és ígéretesebbnek tünik a különböző kivetítések között szelektálni, illetve azokat kombinálni. A gépi tanuláson alapuló modellek paramétereinek optimalizálása, új módszerek kipróbálása bővítené az ehhez használható előrejelzések körét. 


\section{FEJEZET: Befejezés}

Az értekezés három fő részből állt. Előbb az olajár makrogazdasági hatásainak időbeli alakulását, valamint a korábbiakhoz képest mérsékeltebb stagflációs nyomás okait kutattam az Egyesült Államok példáján. Ezt követően Svédország, illetve Norvégia esetén folytonos wavelet transzformációkkal vizsgáltam az olajár és a fontosabb makrogazdasági változók közti kapcsolatot, időben és frekvenciatérben egyaránt. Végül a WTI olajtípus spot árának rövid távú (1-3 napos), valós idejü előrejelezhetőségét teszteltem a modellek egy meglehetősen széles körén, idősorelemzési és gépi tanulásos módszerek felhasználásával.

A II. fejezetben bemutattam, hogy a kőolaj árát számos fundamentális tényező befolyásolja. Bár gyakran csak a kitermelést érintő, vagy legalábbis kockázatossá tevő geopolitikai események kapnak nagyobb figyelmet, a világgazdasági növekedés, a technológiai fejlődés, a piaci hangulat, a dollár ereje, az OPEC müködési környezete mind fontos meghatározói az áralakulásnak. Szintén ebben a fejezetben került bemutatásra az áremelkedés hatásainak begyürüzése a makrogazdasági folyamatokba. A pénzromlás gyorsulását, a munkanélküliség növekedését és a GDP visszaesését nem kizárólag az input költségek emelkedése, valamint az elkölthető jövedelem csökkenése magyarázhatja, hanem az olyan közvetett, aszimmetrikus hatások is, mint az energiaintenzív iparágakból történő elvándorlás (allokációs hatás), a beruházások és a tartós fogyasztási cikkek vásárlásának elhalasztása (bizonytalansági hatás), valamint a monetáris politika alakulása. Ezek egyben arra is választ adhatnak, miért nem követte dinamikus növekedés az 1980-as és 1990-es évek nagy olajár eséseit. Azt azonban nem magyarázzák, miért nem okozott stagflációt a 2000-es években végbement áremelkedés. Egyesek szerint a gazdaság jobb ellenálló képessége (Blanchard és Galí [2007]), míg mások szerint az áremelkedés eltérő forrása (Kilian [2010]) áll a háttérben. Blanchard és Gali [2007] az olajár makrogazdasági hatásainak mérséklődését a technológiai fejlődésre, a rugalmasabb munkaerő-piacra és a hatékonyabb monetáris politikára vezették vissza, Kilian [2010] az olajpiaci áremelkedést előidéző (kínálati, aggregált és specifikus keresleti) sokkok közti különbséget jelölte meg elsődleges okként. A kérdés megválaszolása azért különösen időszerű, mert 2014 nyarán az olajárak meredek esésbe kezdtek, ami egyes elemzők szerint számottevő befolyással bír az importőr és exportőr 
országok gazdasági teljesítményére (Arezki és Blanchard [2014]). Bár e visszaesés hatásainak számszerü előrejelzésére a dolgozatban nem vállalkoztam, a korábbi évek tapasztalatai és saját kutatási eredményeim némi útmutatást adhatnak a várható következményekről.

$\mathrm{Az}$ értekezésben Kalman-szürő segítségével igazoltam, hogy a két megközelítés kiegészíti egymást, ugyanis bár valóban releváns szerepet játszanak az olajár változását kiváltó tényezők, e sokkok hatásairól is belátható, hogy az évtizedek során jelentős változáson mentek keresztül. Ehhez előbb Kilian [2009] strukturális vektorautoregresszív modelljét egy kibővített mintán becsülve generáltam a kitermelést érintő kínálati, a nyersanyagpiacok egészére vonatkozó aggregált keresleti, valamint a kifejezetten az olajvásárlásokat befolyásoló specifikus keresleti sokkok idősorait. Ezt követően megbecsültem e sokkok makrogazdasági hatásait, amiből kiderült összhangban Kilian eredményeivel, de nagyobb mintán és több változóra vonatkozóan , hogy a teljes időszak átlagában a kitermeléshez kötődő sokkhatások nem voltak érdemi befolyással sem az olaj reálárának, sem a vizsgált makromutatóknak (CPI, PCE, GDPdeflátor, PPI, GDP, munkanélküliségi ráta) az alakulására. Ellenben a specifikus és aggregált keresleti sokkok alkalmanként szignifikánsan befolyásolták e változók értékeit. A fejezet fő hozzáadott értéke az ezt követő elemzés, amiben a már említett Kalmanszürős eljárással becsültem a sokkok makrohatásainak - az impulzus válasz függvényeiknek - az időbeli alakulását. Az eredményekből kiderült, hogy az aggregált és specifikus keresleti sokkok hatása az elmúlt évtizedekben több változó esetén is kimutathatóan gyengült, vagy legalábbis mélyponton volt a 2000-es években, amikor az ázsiai növekedés generálta aggregált keresleti sokkok fütötték az áremelkedést. Tehát az olajár és a makrogazdaság közti összefüggés mérséklődése nem csupán az eltérő típusú sokkok következménye, hanem azok időbeli enyhülése, azaz mind Blanchardéknak, mind Kiliannek igaza volt. Igaz, a kutatás nem terjedt ki a Blanchard és Galí [2007] által megjelölt okok tesztelésére, mindenesetre azok potenciális magyarázattal szolgálhatnak a sokkok gyengülő makrogazdasági hatásaira. Emellett arra utaló eredmények is születtek, hogy bizonyos esetekben az olajár emelkedését kiváltó sokkok az utolsó években akár élénkíthették is az amerikai reálgazdaságot, ami összefüggésben állhat az észak-amerikai olajszektor térnyerésével. A specifikus keresleti sokkokra kapott eredmények például azt sugallják, hogy a 2008-as válság utáni kilábalás alatt a növekvő olajárak nem hátráltatták, inkább segítették az amerikai gazdaságot a növekedés 
gyorsításán és a munkanélküliség mérséklésén keresztül. Azonban a 2014-ben indult, föleg a negatív specifikus sokkok által kiváltott masszív áresés kedvezőtlenül érinthette az USA reálgazdaságát, bár a hatás csak rövid ideig, legfeljebb 1-2 negyedéven át tekinthető szignifikánsnak. Ez szöges ellentétben áll a több évtizeden át megfigyelt összefüggéssel, és arra hívja fel a figyelmet, hogy a folytatódó strukturális változás jelentősen befolyásolja majd az amerikai gazdaság sokkokra adott reakcióját, egyszersmind rávilágít a sokkok finomabb felbontásának szükségességére, valamint az importőr és exportőr gazdaságok közti fundamentális különbségekre. Ezért a következő fejezetben egy olajexportőr ország példáján vizsgáltam az összefüggések időbeli alakulását.

A III. fejezet célja, hogy Norvégián keresztül mutassa be egy (speciális helyzetben lévő) exportőr makrogazdasági teljesítményének az olajárral történő együttmozgását. Az Európában irányadónak számító Brent olajtípus jegyzéseit, valamint a CPI inflációt, az ipari termelés és a GDP százalékos változásait használtam az elemzéshez. Az összehasonlíthatóság kedvéért Svédországra is elvégeztem a becsléseket. A fejezet fó hozzáadott értéke nem a norvég gazdaság kitettségének vizsgálata, ezt ugyanis korábban már többen megtették (Bjornland [2000], Jimenez-Rodriguez és Sanchez [2005], Peersman és Van Robays [2012], Bjornland és Thorsrud [2014]), hanem a frekvenciatérben történő elemzés. A folytonos wavelet transzformációk segítségével a kutatás számos értékes eredményre vezetett. Kiderült, hogy az együttmozgás különbözö frekvenciákon valósulhat meg, ugyanabban az időpontban akár ellentétes előjellel, ami indokolja, hogy az idősoros megközelítést a frekvenciatérben történő vizsgálattal egészítsük ki. Az is nyilvánvalóvá vált, hogy a kapcsolat időbeli változása már a frekvencia tartományok szintjén is kimutatható, és gyakran előfordul, hogy ez a dinamika a sima korrelációs elemzéssel rejtett marad. Az eredmények arra utalnak, hogy az olajár és a makrováltozók közti összefüggés módosulása részben az árváltozás eltérő összetételének (a különböző sokkoknak), részben a sokkok változó (többnyire enyhülö) makrogazdasági hatásainak a következménye. A reálgazdasági változók tekintetében Svédországban inkább a kapcsolat gyengülése tapasztalható, míg Norvégiában nem lehet egyértelmű választ adni, úgy tünik, hogy a mintaidőszak során végig képesek voltak többé-kevésbé sikeresen függetleníteni gazdasági teljesítményüket az olaj árától. Az inflációs folyamatok esetében mindkét országban az figyelhető meg, hogy előbb a 3-8, majd a 2000-es években az 1-3 éves frekvencia tartományban mutattak szignifikáns 
kapcsolatot a nominális olajár változásával. Összességében úgy tünik, hogy Norvégiában valamivel lazább a makrováltozók és az olajár kapcsolata, mint a nyersanyagot importáló Svédországban, bár a sokkokkal való együttmozgás a teljes mintaidőszakot tekintve már erősebb volt, legalábbis a reálgazdasági változók esetében. Ennek ellenére kijelenthető, hogy több exportőrrel szemben a norvég gazdaságot nem jellemzi az olajárak volatilitásának (vagy az ezt kiváltó sokkoknak) való erős kitettség.

Végezetül a IV. fejezetben különböző ökonometriai és gépi tanuláson alapuló modellekkel vizsgáltam a spot WTI olajár rövid távú (1-3 napos), valós idejü előrejelezhetőségét. ARIMA, ARX, LPM, logit, SVM és neurális hálós eljárásokkal, WTI futures, valamint benzin és fütőolaj spot árakkal készítettem projekciókat a 2011-2014es tesztidőszakra. A kiértékelést több mutató (MAE, RMSE, találati arány, realizált profit) mentén is elvégeztem, az egyes években jól teljesítő modellek halmazát pedig az eltolásos vagy eltolás nélküli véletlen bolyongásból származó benchmark értékhez történő viszonyítással alakítottam ki. Az eredmények alapján a legjobb modellek halmaza meglehetősen instabil, mind az előrejelzési horizont (1, 2 vagy 3 napos kivetítés), mind a tesztminta (2011, 2012, 2013 vagy 2014) megválasztása erősen befolyásolja azt, és az alkalmazott hibamutató is sokat számít. Nincs olyan univerzális eljárás, ami az évek során tartósan a benchmarknál pontosabb elörejelzéseket biztosított volna minden horizont/hibamutató pár mentén. Ha kizárólag egyetlen illeszkedési vagy hibamutatóra szorítkozunk, akkor is előfordul, hogy nincs a benchmarkot minden évben legyőző modell, vagy ha igen, akkor sem találni olyat, ahol a viszonyítási alaptól való eltérés minden évben szignifikáns lett volna. Ugyanakkor az olaj futures valamint az olajszármazék spot árak bevonásával valamelyest javítható az előrejelzés pontossága, a legjobb modellek halmazában legalábbis erősen felülreprezentáltak ezek a megközelítések. Bár az elemzés során inkább ökonometriai eljárások kerültek a priorizált csoportba, a gépi tanulás alkalmazása még komoly potenciált rejthet magában, ami a hipotetikus profitmutatók nagyságából, valamint az idősorelemzési, illetve gépi tanulásos modellek medián teljesítményeinek összehasonlításából látható. Megjegyzendő továbbá, hogy a változók LASSO-val és LASSOGLM-mel történő előzetes szelekciója sem oldotta meg a robusztussági problémát, föleg a pontbecslés esetében volt jellemző a benchmarknál rosszabb elörejelzési teljesítmény. 


\section{Függelék}

\section{F1. SVM (support vector machine)}

Ebben a részben az SVM (support vector machine) eljárás részletei kerülnek bemutatásra. Előbb a lineárisan szeparálható eseteket vizsgálom, majd megnézem, mi történik, ha lineárisan nem szeparálható problémával állunk szemben. A levezetés során végig felteszem, hogy a függő változó bináris, és csupán két kimenet lehetséges $\left(y_{i} \in\{-1 ; 1\}\right)$. A szeparációt $k$ darab magyarázó változó mentén végzem, és összesen $n$ megfigyelés áll rendelkezésre, azaz $x_{i} \in \mathbb{R}^{k}$, ahol $i=1,2, \ldots, n$.

\section{A lineárisan szeparálható eset}

Először felteszem, hogy a megfigyelések két lineárisan szétválasztható csoportba sorolhatók (pl. növekvő/csökkenő árak)! Könnyen belátható, hogy ekkor végtelen sok szeparáló hipersík létezik, és az optimális hipersík kiválasztása a felhasználó céljaitól függ. Az SVM eljárás ebben az esetben azt a hipersíkot választja, amely a lehető legtávolabb van a két megfigyeléscsoport széleitől. A kategóriák széleit jelen esetben azok a megfigyelések jelentik, amelyek a legközelebb vannak a szeparáló hipersíkhoz. Formálisan ez a következőt jelenti:

- A szeparáló hipersík egyenlete: $w^{T} x+b=0$, ahol $w$ és $x$ kx1-es oszlopvektorok, $b$ konstans.

- A két katagória szélső megfigyelései (a tartó vektorok) a hipersíkkal párhuzamos egyeneseken helyezkednek el, mégpdig: $w^{T} x+b=-1$ vagy $w^{T} x+b=1$.

- Ekkor a két párhuzamos egyenes távolsága $2 /\|w\|$-val lesz egyenlő.

Ebből kifolyólag az SVM a következő optimalizációs problémával ekvivalens:

$$
\begin{gathered}
\min _{w, b} \frac{1}{2}\|w\|^{2} \\
\text { s.t.: } y_{i}\left(w^{T} x_{i}+b\right) \geq 1(\forall i-r e)
\end{gathered}
$$


Kihasználva, hogy $\|w\|^{2}=w^{T} w$, felírható a Lagrange-függvény:

$$
\mathcal{L}=\frac{1}{2} w^{T} w+\sum_{i=1}^{n} \alpha_{i}\left[1-y_{i}\left(w^{T} x_{i}+b\right)\right]
$$

Ahol $\alpha_{i} \geq 0 \quad(\mathrm{i}=1 ; \ldots ; \mathrm{n})$ jelöli a Lagrange-multiplikátorokat. Innen az elsőrendü feltételeket az $\mathcal{L}$ függvény $w$ és $b$ szerinti deriválásával kapjuk:

$$
\begin{gathered}
w=\sum_{i=1}^{n} \alpha_{i} y_{i} x_{i} \\
\sum_{i=1}^{n} \alpha_{i} y_{i}=0
\end{gathered}
$$

Ezeket visszaírva a Lagrange-függvénybe, némi egyszerüsítés és behelyettesítés után a következő kifejezéshez jutunk:

$$
\mathcal{L}=\sum_{i=1}^{n} \alpha_{i}-\frac{1}{2} \sum_{i=1}^{n} \sum_{j=1}^{n} \alpha_{i} \alpha_{j} y_{i} y_{j} x_{i}^{T} x_{j}
$$

Ebben a felírásban már kizárólag a Lagrange-multiplikátorok az ismeretlenek, azaz nem muszáj az eredeti primál feladat megoldására koncentrálni, elég ha a jóval egyszerübben kezelhető duál megközelítést használjuk. Az optimalizációs feladat:

$$
\begin{aligned}
& \max _{\alpha_{1} ; \ldots ; \alpha_{n}} \sum_{i=1}^{n} \alpha_{i}-\frac{1}{2} \sum_{i=1}^{n} \sum_{j=1}^{n} \alpha_{i} \alpha_{j} y_{i} y_{j} x_{i}^{T} x_{j} \\
& \text { s.t.: } \alpha_{i} \geq 0(\forall i-r e) \text { és } \sum_{i=1}^{n} \alpha_{i} y_{i}=0
\end{aligned}
$$


A fenti kvadratikus programozási feladat megoldásaként előálló $\alpha_{i}$ paraméterekből a $w=$ $\sum_{i=1}^{n} \alpha_{i} y_{i} x_{i}$ összefüggéssel már ki lehet számolni a szeparáló hipersík képletét:

$$
\sum_{i=1}^{n} \alpha_{i} y_{i} x_{i}^{T} x+b=0
$$

Ugyanakkor az $\alpha_{i}$ paraméterek többsége nulla lesz, kizárólag a tartó vektorokhoz tartozó súlyok kapnak pozitív értéket:

$$
\sum_{i \in S V} \alpha_{i} y_{i} x_{i}^{T} x+b=0
$$

Ahol $S V$ a tartó vektorok (support vectors) halmazát jelöli. A $b$ paraméter értékét bármely tartó vektor segítségével ki lehet számolni, pl. az y=1-es kategóriába eső $x_{j}$ tartóvektor esetén a $\sum_{i \in S V} \alpha_{i} y_{i} x_{i}^{T} x_{j}+b=1$ képletböl. Az új megfigyelések besorolása pedig attól függ, hogy a szétválasztó egyenes melyik oldalára esnek. Legyen például az új megfigyelés $\mathbf{z}$ ! Ekkor $\sum_{i \in S V} \alpha_{i} y_{i} x_{i}^{T} z+b>0$ esetén az SVM becslése $\hat{y}=1$, különben $\hat{y}=-1$.

Az olajárak változását modellező alkalmazásnál az optimalizáció SMO (sequential minimal optimatization) eljárással történik, melynek főbb lépései a következők:

- véletlenszerüen választ egy olyan induló pontot ( $\alpha$ értékeket), amelyek teljesítik a feltételeket

- ezek közül véletlenszerüen kiválaszt kettőt, és a többi paraméter változatlanságának feltétele mellett megoldja a kvadratikus programozási feladatot

- ezután újra véletlenszerüen kiválaszt két paramétert, és megismétli az optimalizálást, ezúttal is a többi változatlanságának feltételezése mellett (de a korábban már kiválasztásra került paramétereknél a legfrissebb értékeket használja)

- az eljárást a konvergenciáig (a globális optimum megtalálásáig) ismétli

Az eljárás során problémát okozhat, ha egyes input változók széles, míg mások szük skálán mozognak, ekkor ugyanis előfordulhat, hogy az első csoport tagjai dominálják a 
másodikba eső változókat, és a hipersík kialakításakor a kelleténél nagyobb súlyt kapnak. Ennek kiküszöbölésére sztenderdizálást használhatunk.

\section{A lineárisan nem szeparálható eset és a kernel-trükk}

$\mathrm{Az}$ empirikus alkalmazások többségében lineárisan nem szeparálható példákkal találkozunk, így az ismertetett SVM-nek nincs megoldása (nem létezik olyan hipersík, ami a megadott változók mentén tökéletesen elválasztaná egymástól a két csoportot). Ebben az esetben a cél a lehető legkisebb hibával járó klasszifikáció. A hiba itt egyrészt a rossz csoportba való besorolást, másrészt ennek a téves klasszifikációnak a „mértékét” jelenti. Utóbbi alatt azt kell érteni, hogy minél távolabb esik a hipersíktól a rossz helyre sorolt megfigyelés, annál jobban bünteti a célfüggvény. Formálisan ez azt jelenti, hogy a primál feladat célfüggvényét egy újabb taggal egészítjük ki:

$$
\begin{gathered}
\min _{w, b, s} \frac{1}{2}\|w\|^{2}+c \sum_{i=1}^{n} g\left(s_{i}\right) \\
\text { s.t.: } y_{i}\left(w^{T} x_{i}+b\right) \geq 1-s_{i} \text { és } s_{i} \geq 0(\forall i-r e)
\end{gathered}
$$

Ahol $s_{i}$ segédváltozó a hiba mértékét mutatja, $g\left(s_{i}\right)$ ennek a célfüggvényben szereplő transzformáltja, $c$ pedig a ,távolság” büntetésének súlya. Az SVM empirikus alkalmazásaiban az $\mathrm{L}^{1}\left(g\left(s_{i}\right)=s_{i}\right)$ és $\mathrm{L}^{2}\left(g\left(s_{i}\right)=s_{i}^{2}\right)$ normák használata a legelterjedtebb. Az olajár-változás irányának előrejelzésére az előbbi felírást használom.

A lineárisan szeparálható eset analógiájára belátható, hogy ekkor a duál feladat:

$$
\begin{gathered}
\max _{\alpha_{1} ; \ldots ; \alpha_{n}} \sum_{i=1}^{n} \alpha_{i}-\frac{1}{2} \sum_{i=1}^{n} \sum_{j=1}^{n} \alpha_{i} \alpha_{j} y_{i} y_{j} x_{i}^{T} x_{j} \\
\text { s.t.: } c \geq \alpha_{i} \geq 0(\forall i-r e) \text { és } \sum_{i=1}^{n} \alpha_{i} y_{i}=0
\end{gathered}
$$

Ez a feladat gyakorlatilag ekvivalens a korábban levezetett kvadratikus programozási problémával, így megoldása is hasonló módon (SMO eljárással) történik. 
A lineárisan nem szeparálható esetekben ugyanakkor jellemzően felmerül a nemlineáris szeparáció igénye. E megközelítés azonban túlságosan általános, lényegében végtelen sok lehetőség közül választhatunk, és könnyen előfordulhat a túlillesztés. A kernel-trükk lényege, hogy továbbra is az SVM által meghatározott hipersíkkal metszi két részre a teret, ezt azonban nem az eredeti térben teszi. Illusztrációként tekintsük a következő esetet, ahol az első $(y=-1)$ csoport tagjait körök, míg a második $(y=1)$ csoport tagjait négyzetek jelölik!

Látható, hogy egyetlen egyenessel nem tudjuk pontosan elválasztani a halmazokat, azonban egy másik térben tekintve a problémát már lehetséges a lineáris szeparáció. Ehhez elég ábrázolnunk az $\mathrm{f}(\mathrm{x})=\mathrm{x}^{2}$ függvényt:

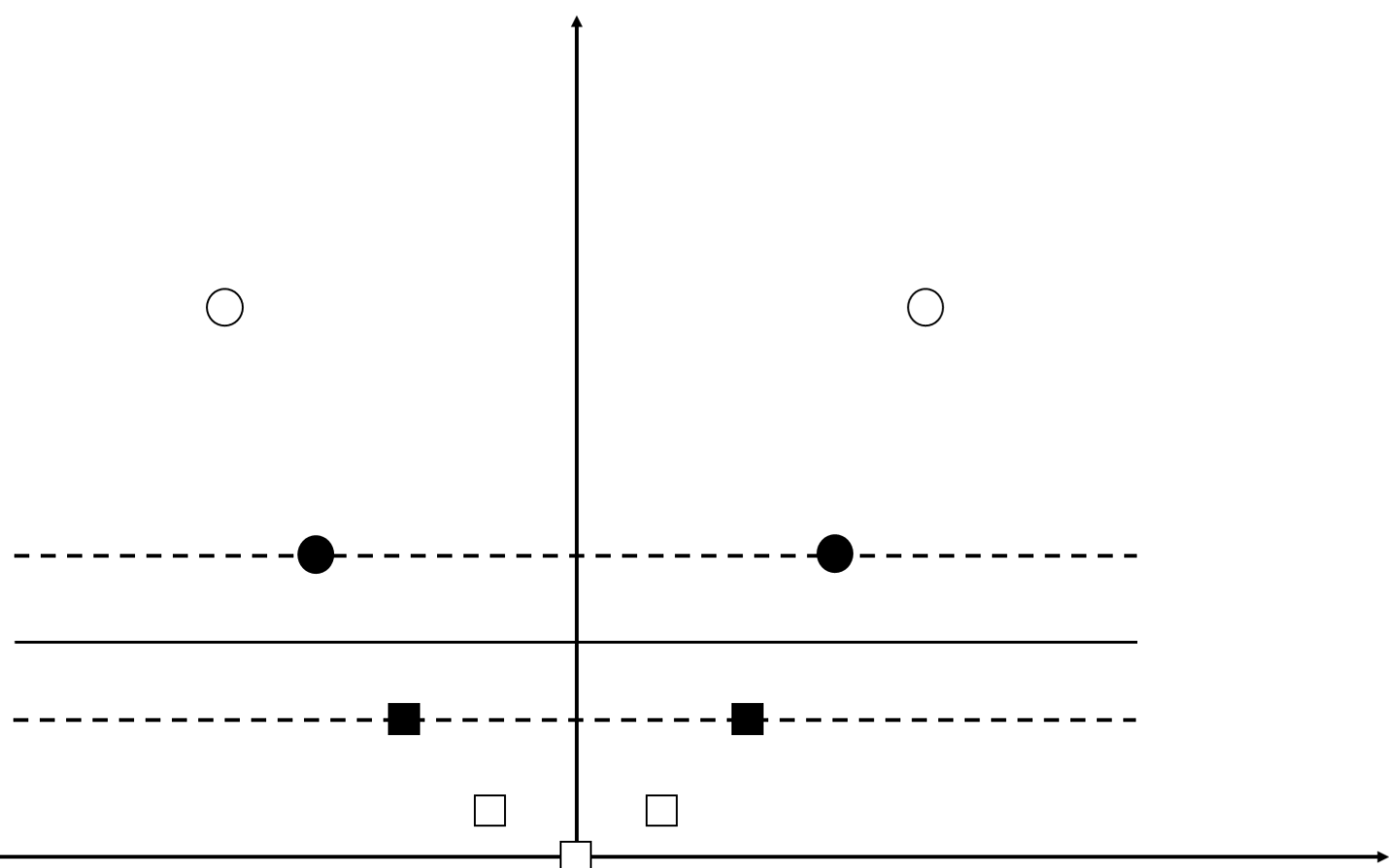


A probléma magasabb dimenziójú térbe való átírása, és az SVM eljárás e térben történő alkalmazása tehát jó megoldást ad, ugyanakkor komplexebb feladatoknál nincs lehetőség minden szóba jöhető esetet megvizsgálni, és az sem reális elvárás, hogy a modellező magától rájöjjön a helyes transzformációra. Ezért alkalmazzák a kernel-trükköt, aminek lényege, hogy egy kernel függvényt illesztenek a duál feladat célfüggvényébe:

$$
\begin{aligned}
& \max _{\alpha_{1} ; \ldots ; \alpha_{n}} \sum_{i=1}^{n} \alpha_{i}-\frac{1}{2} \sum_{i=1}^{n} \sum_{j=1}^{n} \alpha_{i} \alpha_{j} y_{i} y_{j} K\left(x_{i}, x_{j}\right) \\
& \text { s.t.: } c \geq \alpha_{i} \geq 0(\forall i-r e) \text { és } \sum_{i=1}^{n} \alpha_{i} y_{i}=0
\end{aligned}
$$

Ahol $K\left(x_{i}, x_{j}\right)=\varphi\left(x_{i}\right)^{T} \varphi\left(x_{j}\right)$ jelöli a pozitív definit kernel függvényt, $\varphi($.$) pedig a$ magasabb dimenziójú térbe történő transzformációt (amit azonban nem kell ismerni a feladat megoldásához). A kernel függvény gyakorlatilag egy hasonlósági mérték, és jó választással a hasonlósági függvények egy széles halmazát tudjuk vele közelíteni. A két leggyakrabban használt kernel függvény:

- magasabb rendü polinom: $K\left(x_{i}, x_{j}\right)=\left(x_{i}^{T} x_{j}+1\right)^{k}$

- radiális bázisfüggvény $(\mathrm{RBF}): K\left(x_{i}, x_{j}\right)=e^{\frac{\left\|x_{i}-x_{j}\right\|^{2}}{2 \sigma^{2}}}$

A feladat megoldása továbbra is SMO algoritmussal történik, az új megfigyeléseket pedig szintén a korábban leírtak analógiájára soroljuk egyik vagy másik csoportba.

Érdemes még megjegyezni, hogy az SVM-nek számos kiterjesztése létezik. Bekövetkezési valószínüségeket rendelhetünk a becsült kimenetekhez, megkülönböztethetünk kettőnél több kategóriát, használhatjuk regressziós becsléshez (SVR, support vector regression) stb. Mivel az olajár-előrejelzés megvalósításához nem használom ezeket az eszközöket, így ismertetésüktől eltekintek. 


\section{F.2. Ábrák}

36. ábra: A sokkok kumulált hatása az Egyesült Államok PPI és PCE mutatóira (0-12 negyedév)

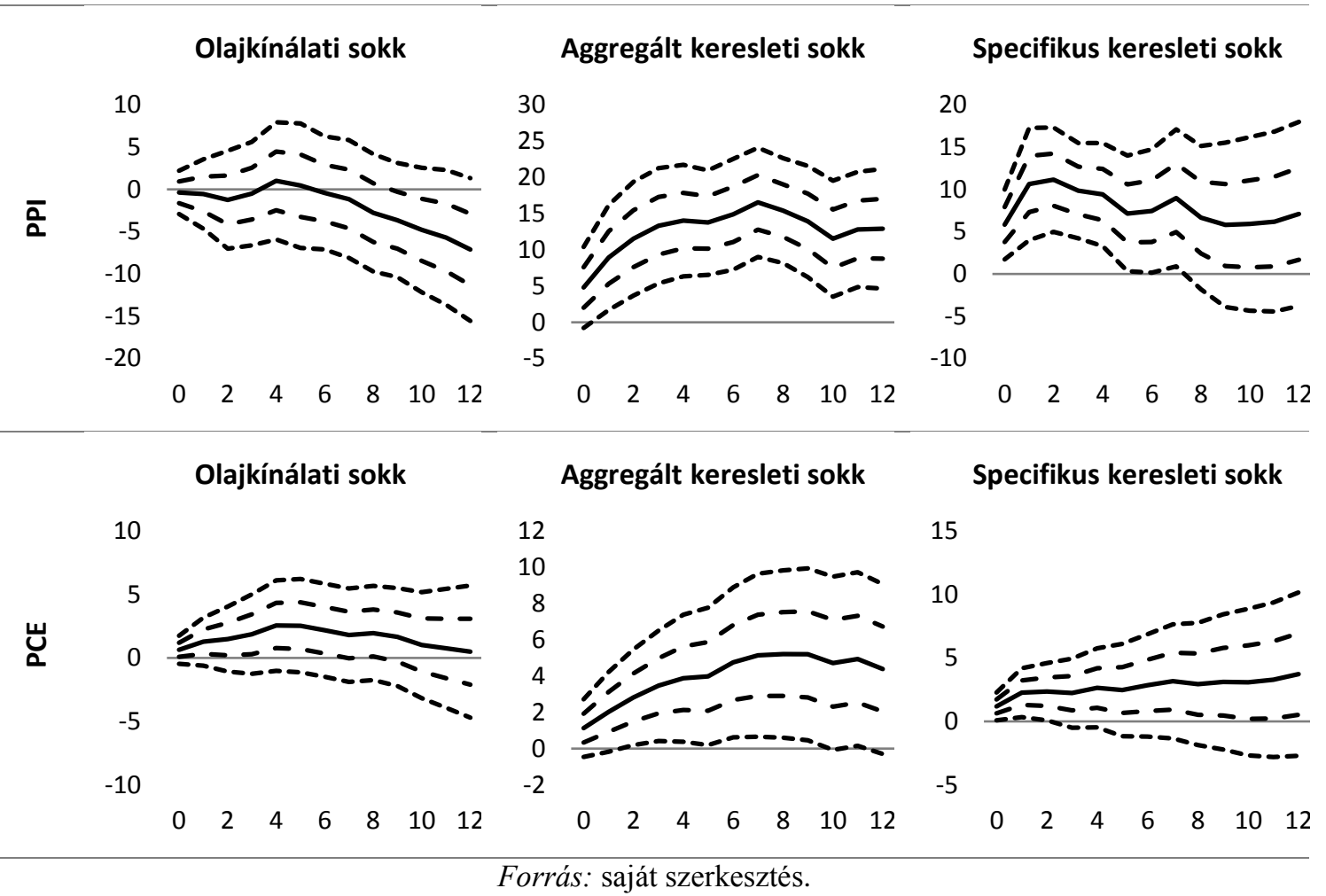


37. ábra: Egységnyi sokk kumulált hatása az amerikai PPI indexre (időben változó paraméterü modell eredményei)
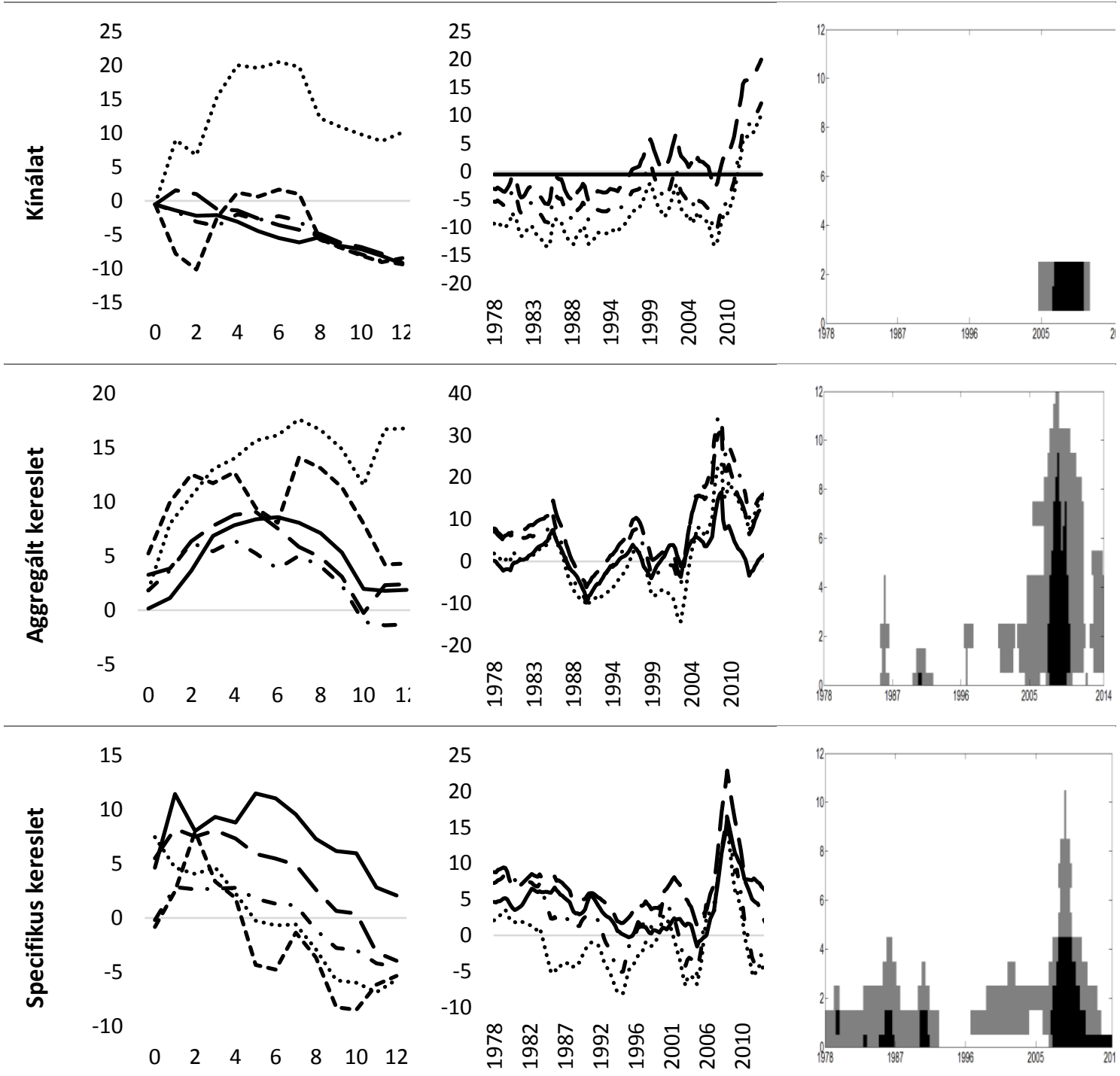

Forrás: lásd a 9. ábrát. 
38. ábra: Egységnyi sokk kumulált hatása az amerikai PCE indexre (időben változó paraméterü modell eredményei)
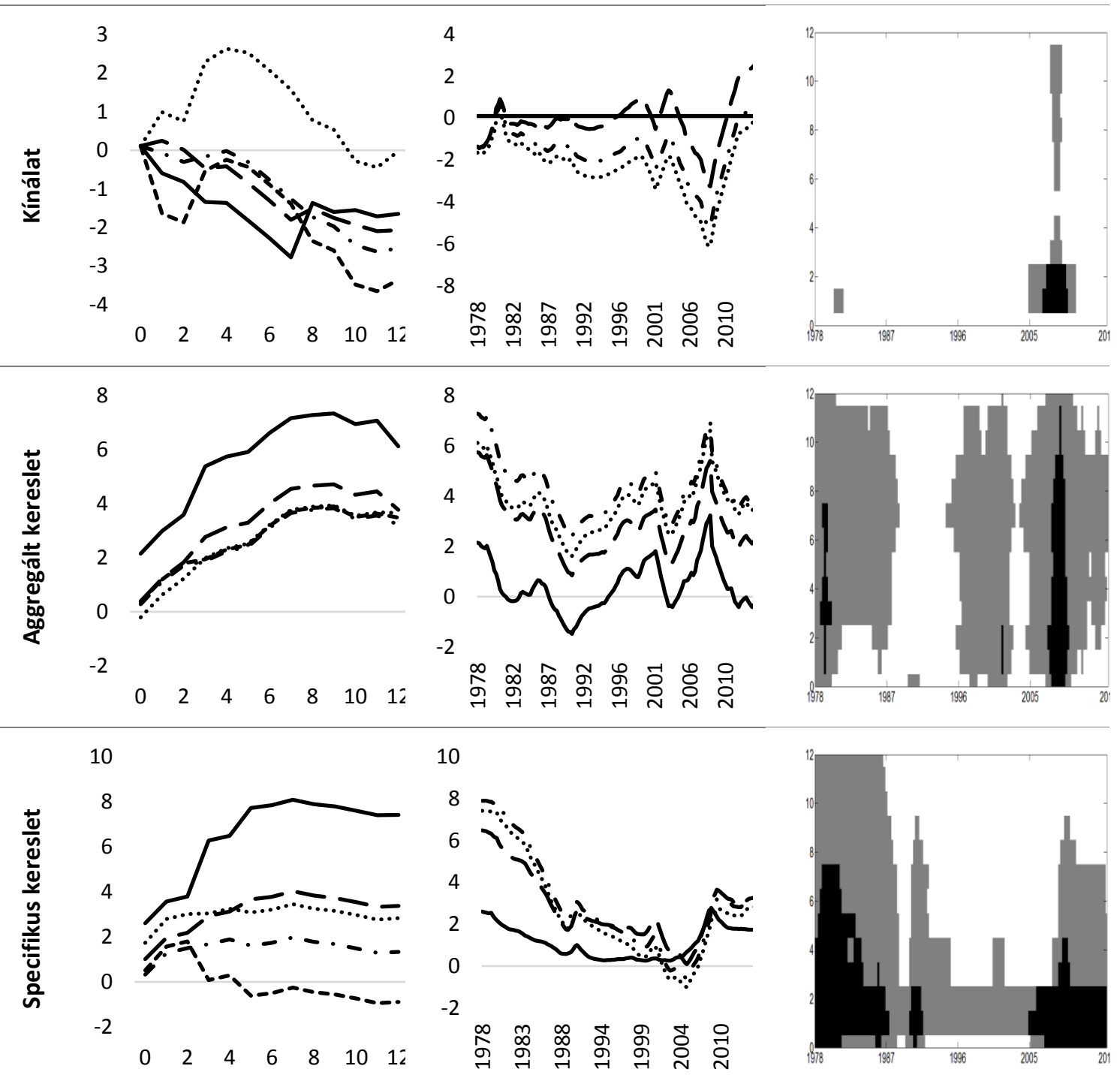

Forrás: lásd a 9. ábrát. 
39. ábra: Egységnyi sokk kumulált hatása az amerikai CPI-re (Kilian [2009] féle modell eredményei a minta első és második felére külön megbecsülve)

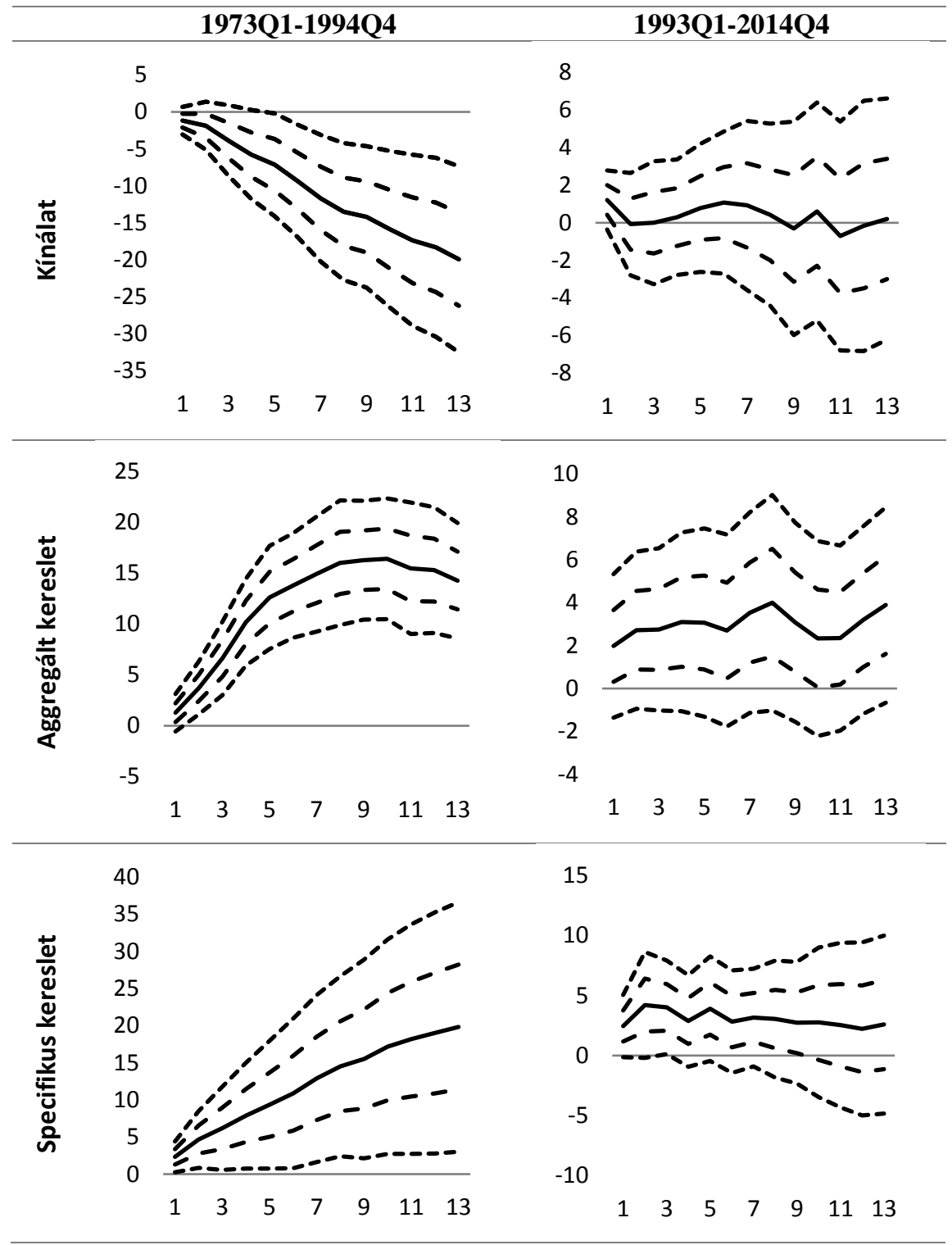

Forrás: lásd a 8 . ábrát. 
40. ábra: Egységnyi sokk kumulált hatása az amerikai GDP-re (Kilian [2009] féle modell eredményei a minta első és második felére külön megbecsülve)

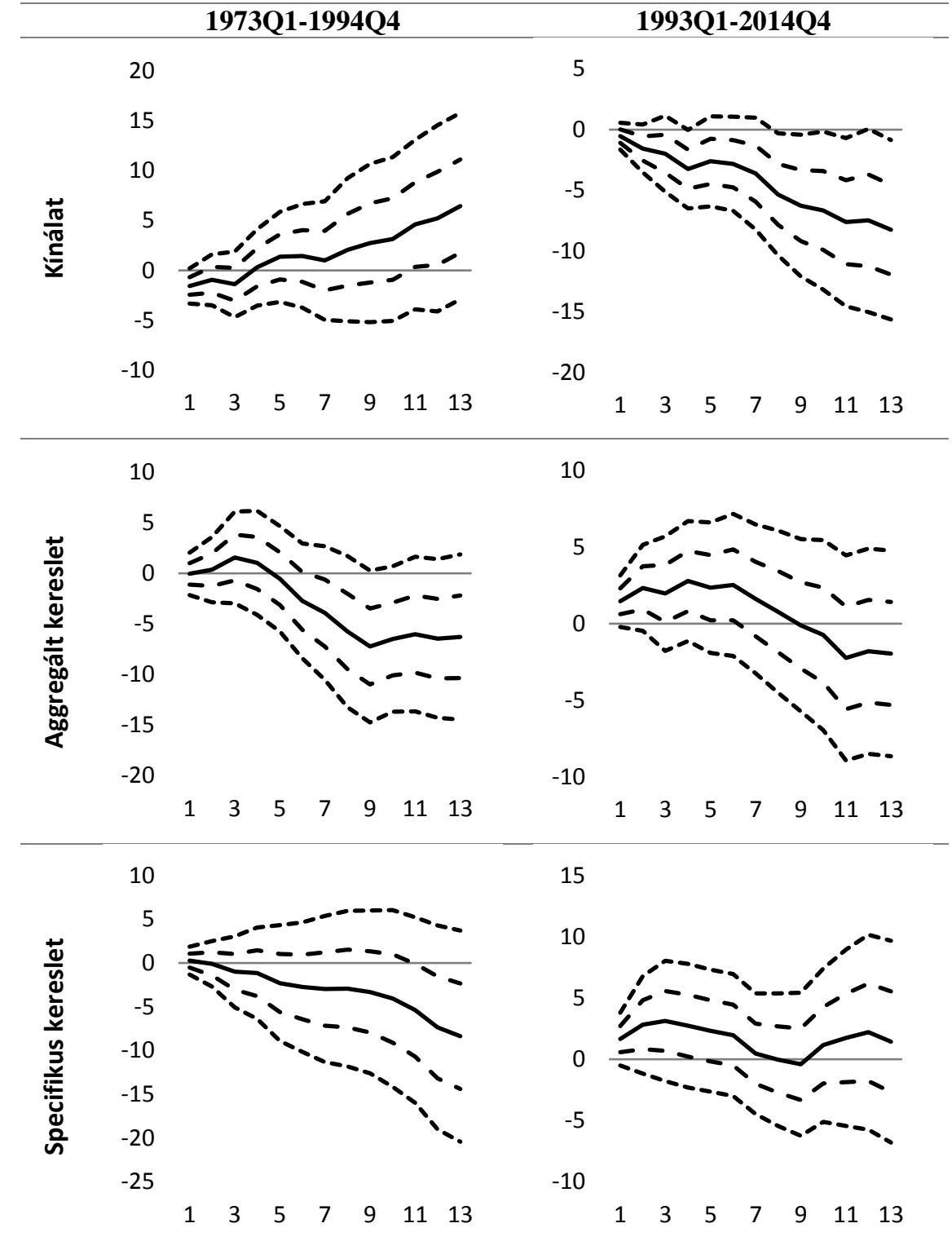

Forrás: lásd a 8 . ábrát. 
41. ábra: Egységnyi sokk kumulált hatása az amerikai implicit árindexre (Kilian [2009] féle modell eredményei a minta első és második felére külön megbecsülve)

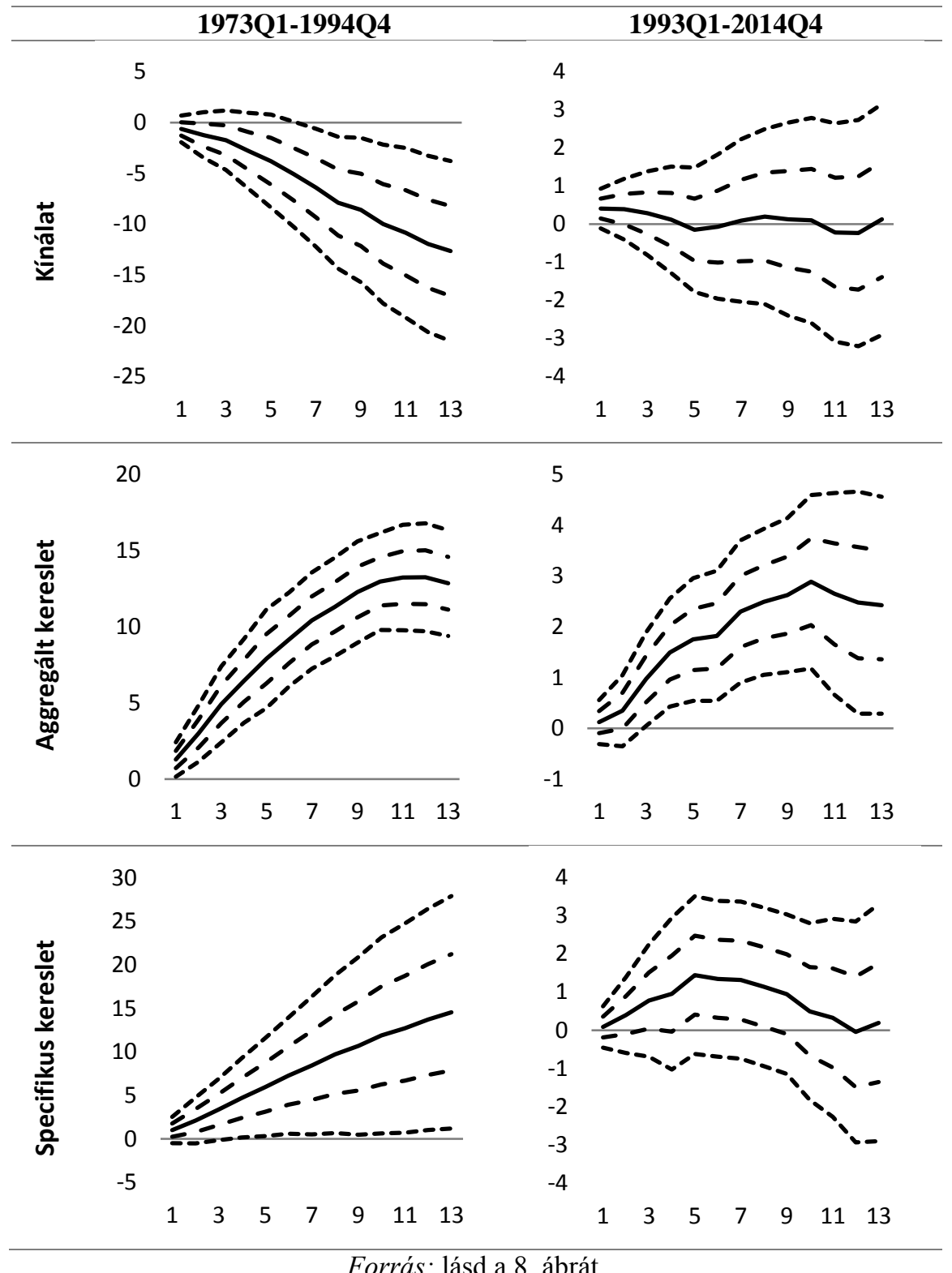


42. ábra: Egységnyi sokk kumulált hatása az amerikai PCE-re (Kilian [2009] féle modell eredményei a minta első és második felére külön megbecsülve)

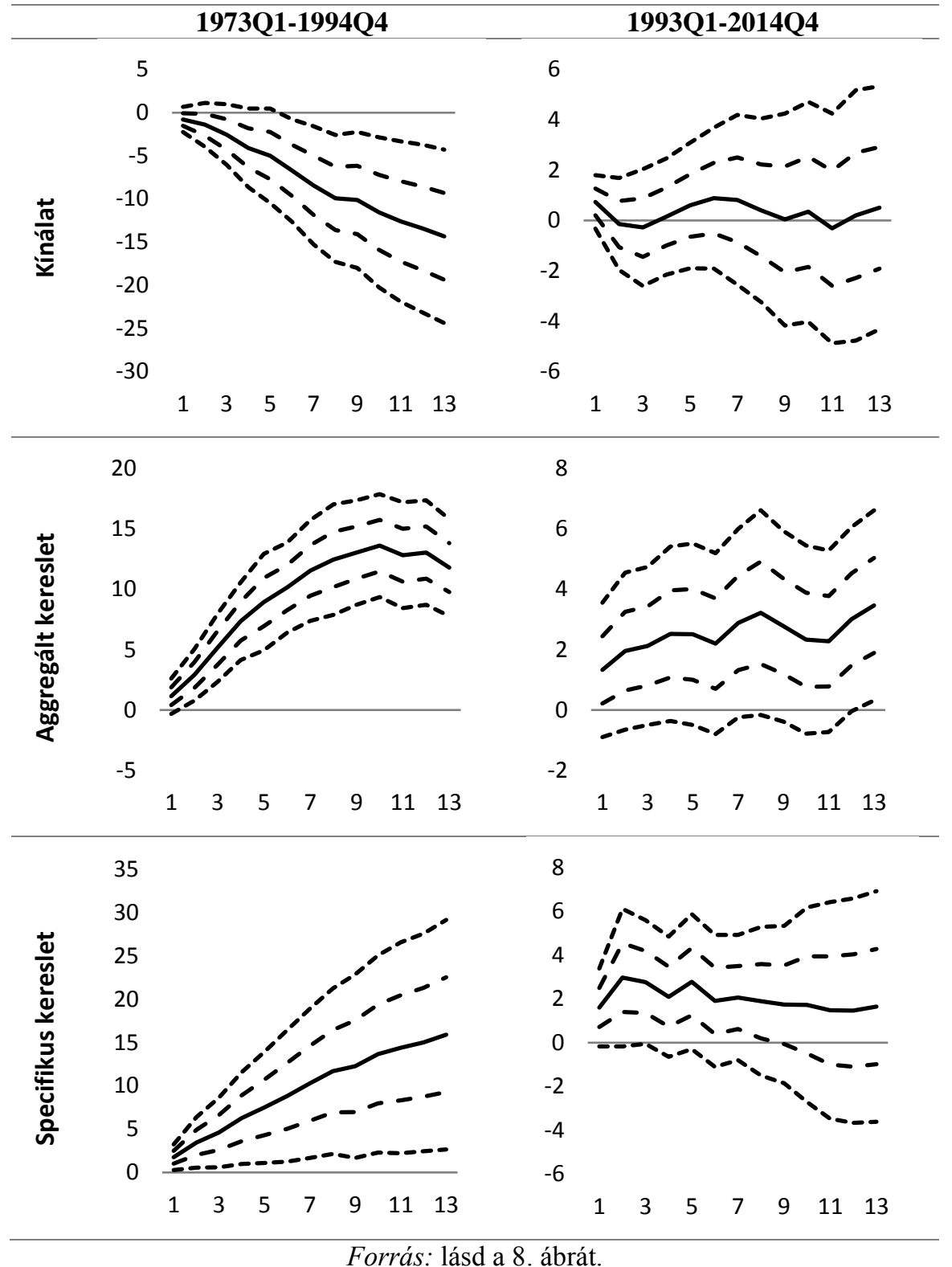


43. ábra: Egységnyi sokk kumulált hatása az amerikai PPI-re (Kilian [2009] féle modell eredményei a minta első és második felére külön megbecsülve)

(19)


44. ábra: Egységnyi sokk kumulált hatása az amerikai munkanélküliségi rátára (Kilian [2009] féle modell eredményei a minta első és második felére külön megbecsülve)

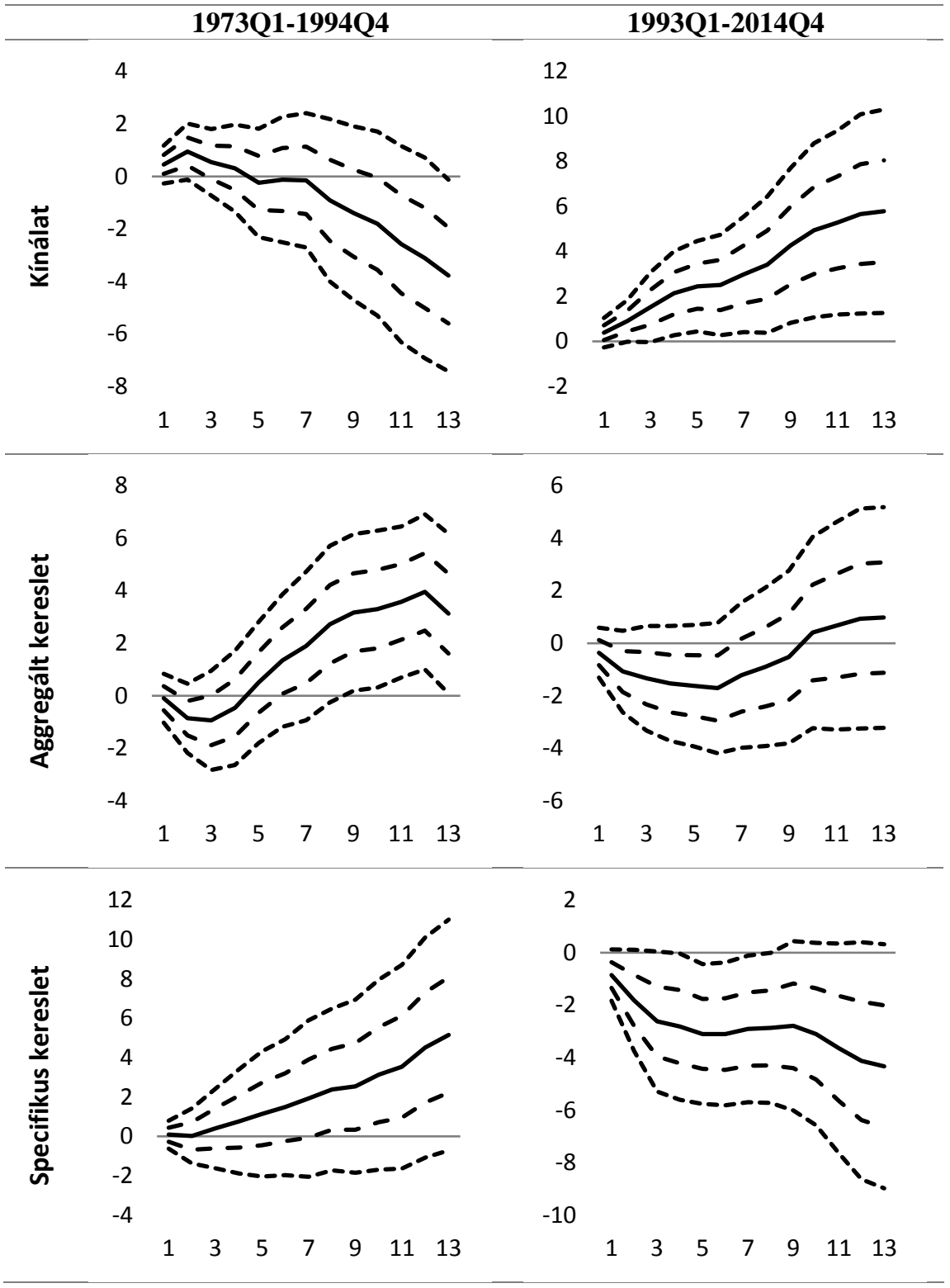

Forrás: lásd a 8. ábrát. 
45. ábra: Egységnyi kínálati sokk hatása az Egyesült Államok makrogazdasági mutatóira (időben változó paraméterü bővített modell eredményei)
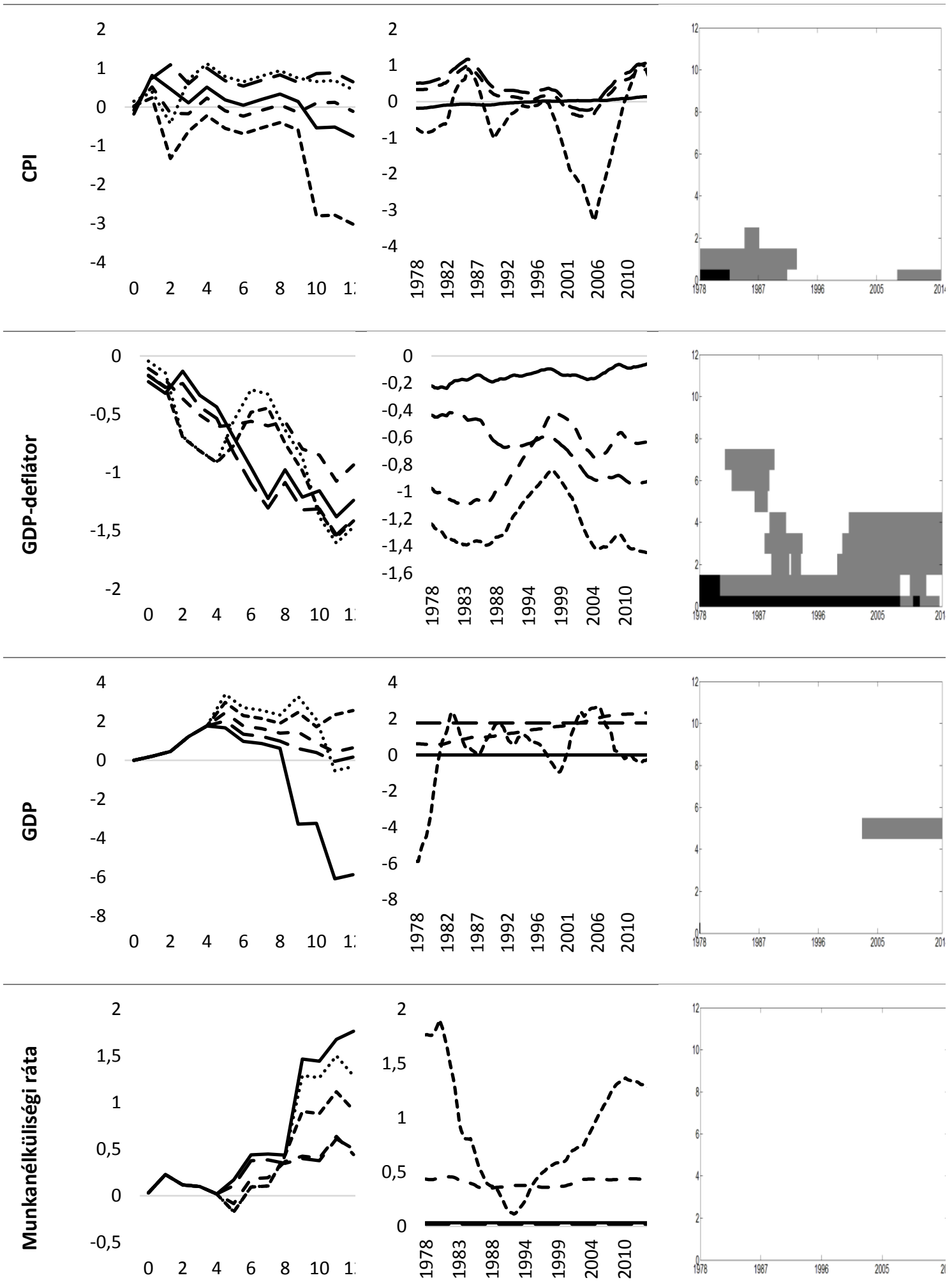

Forrás: lásd a 9. ábrát. 
46. ábra: Egységnyi aggregált keresleti sokk hatása az Egyesült Államok

makrogazdasági mutatóira (időben változó paraméterü bővített modell eredményei)
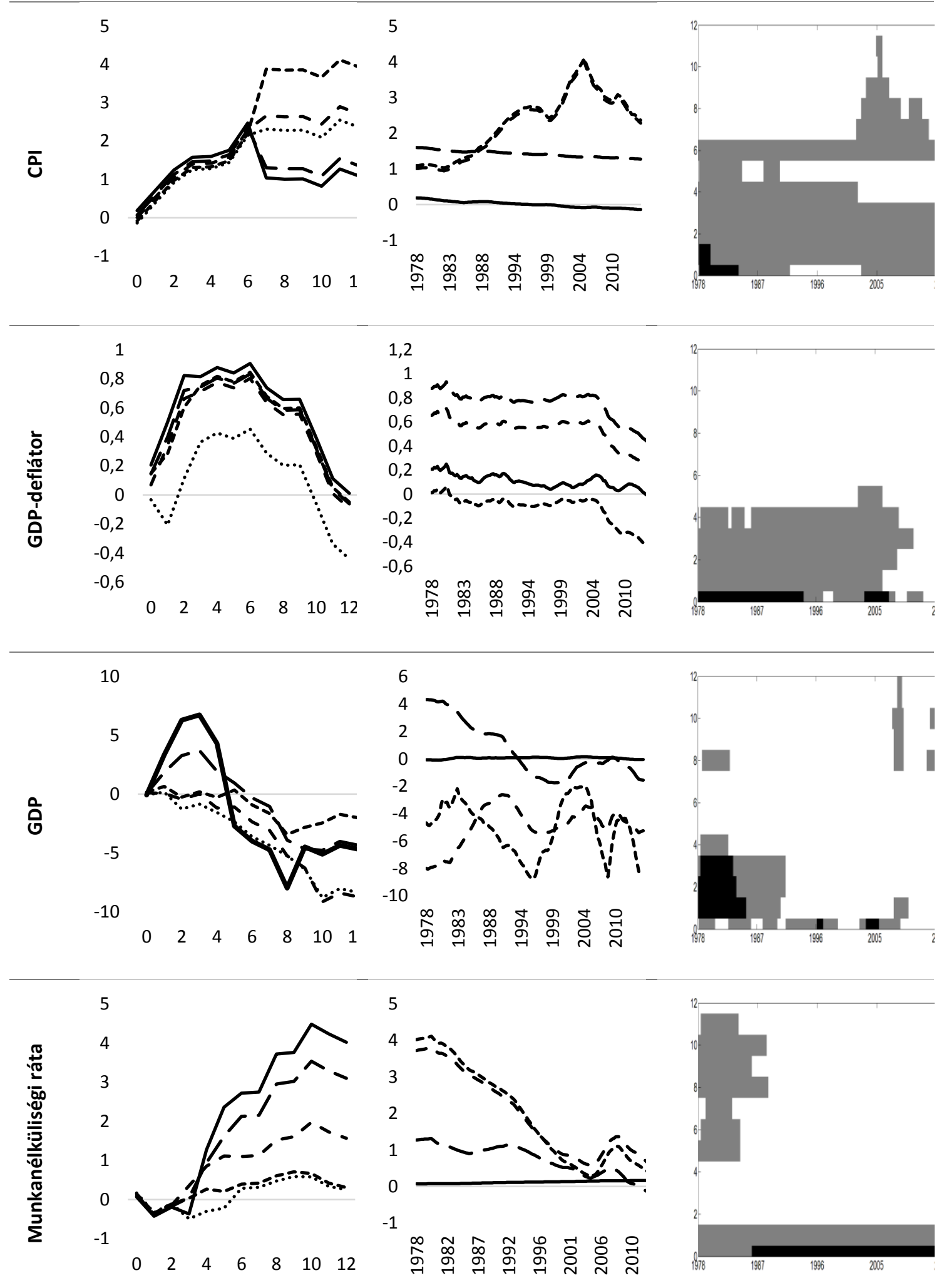

Forrás: lásd a 9. ábrát. 
47. ábra: Egységnyi specifikus keresleti sokk hatása az Egyesült Államok makrogazdasági mutatóira (időben változó paraméterü bővített modell eredményei)
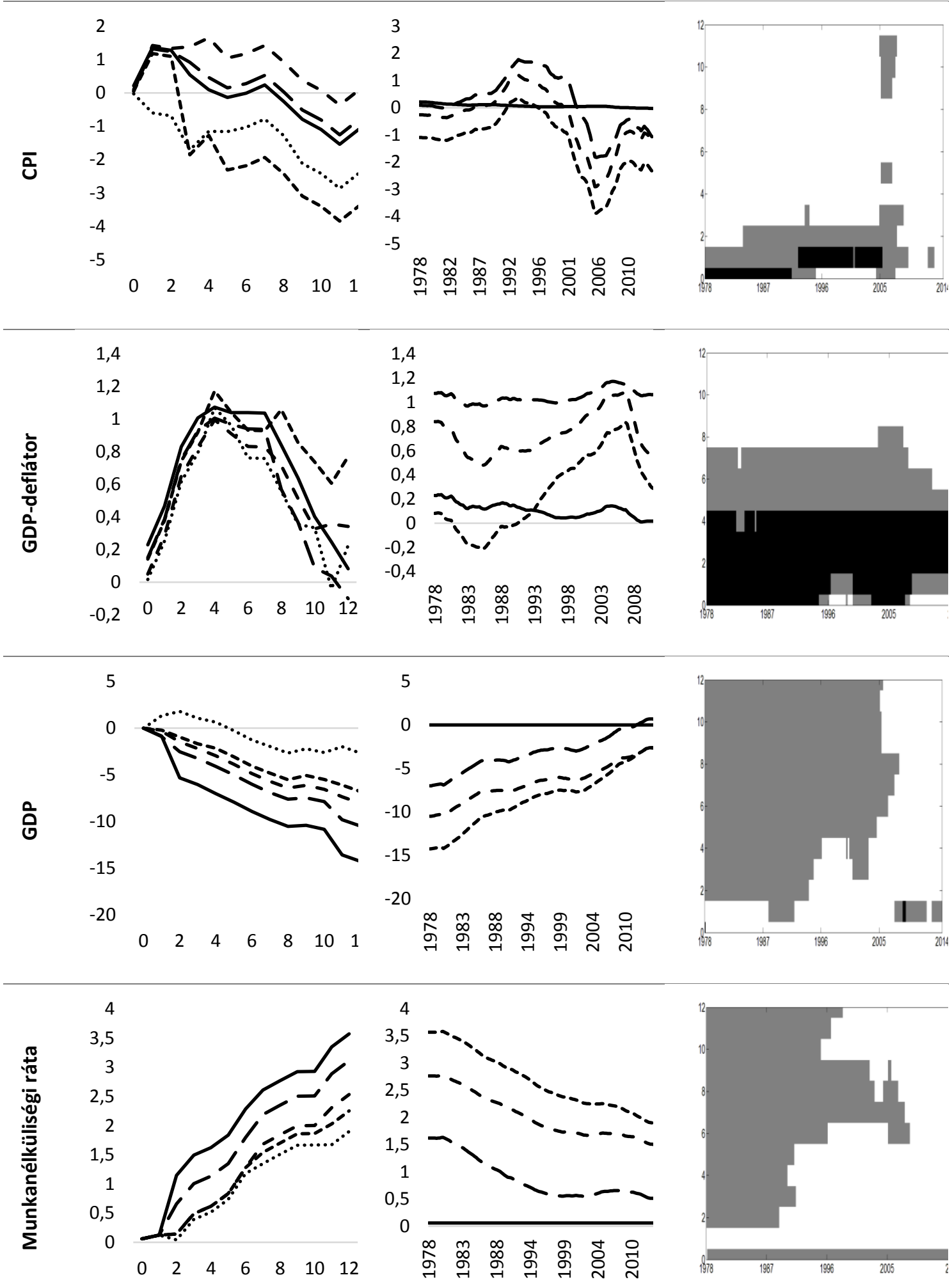

Forrás: lásd a 9. ábrát. 


\section{F.3. Táblázatok}

\section{F.3.1. Robusztussági vizsgálatok}

19. táblázat: A Kalman-szürőből származó kumulált IVF-ek negyedéves értékeiből számolt átlagok különbsége a minta első és második fele között

\begin{tabular}{|c|c|c|c|c|c|c|c|c|c|c|c|c|c|c|c|c|c|c|}
\hline & \multicolumn{3}{|c|}{ CPI } & \multicolumn{3}{|c|}{ GDP } & \multicolumn{3}{|c|}{ GDPDEF } & \multicolumn{3}{|c|}{ PCE } & \multicolumn{3}{|c|}{ PPI } & \multicolumn{3}{|c|}{ Munkanélk. } \\
\hline & $\mathbf{S}$ & $A D$ & SD & $\mathbf{S}$ & $A D$ & SD & $\mathbf{S}$ & AD & SD & $\mathbf{S}$ & $A D$ & SD & $\mathbf{S}$ & AD & SD & $S$ & AD & SD \\
\hline 0 & 0 & 1 & 1 & 1 & 1 & 1 & 1 & -1 & -1 & 0 & 1 & -1 & 0 & 1 & -1 & 1 & 0 & -1 \\
\hline 1 & -1 & -1 & 1 & 1 & -1 & 1 & 1 & -1 & -1 & -1 & 1 & -1 & -1 & 1 & -1 & 1 & 0 & -1 \\
\hline 2 & -1 & -1 & 1 & 1 & -1 & 1 & -1 & -1 & -1 & -1 & 1 & -1 & -1 & 1 & 1 & 1 & 0 & -1 \\
\hline 3 & 1 & -1 & -1 & -1 & -1 & 1 & -1 & -1 & -1 & 1 & -1 & -1 & 1 & 1 & 1 & 1 & 1 & -1 \\
\hline 4 & 1 & -1 & -1 & -1 & -1 & 1 & -1 & -1 & 1 & 1 & -1 & -1 & 1 & 1 & -1 & 1 & -1 & -1 \\
\hline 5 & 1 & -1 & -1 & 1 & -1 & -1 & -1 & -1 & -1 & 1 & -1 & -1 & 1 & 1 & -1 & 1 & -1 & -1 \\
\hline 6 & 1 & -1 & -1 & 1 & -1 & -1 & 1 & -1 & -1 & 1 & -1 & -1 & 1 & 1 & -1 & 1 & -1 & -1 \\
\hline 7 & 1 & -1 & -1 & 1 & -1 & -1 & 1 & -1 & -1 & 1 & -1 & -1 & 1 & 1 & -1 & 1 & -1 & -1 \\
\hline 8 & 1 & -1 & -1 & 1 & 1 & -1 & 1 & -1 & -1 & -1 & -1 & -1 & 1 & 1 & -1 & 1 & -1 & -1 \\
\hline 9 & 1 & -1 & -1 & 1 & -1 & -1 & 1 & -1 & -1 & -1 & -1 & -1 & 1 & 1 & -1 & 1 & -1 & -1 \\
\hline 10 & -1 & -1 & -1 & -1 & -1 & -1 & 1 & -1 & -1 & -1 & -1 & -1 & 1 & 1 & -1 & 1 & -1 & -1 \\
\hline 11 & -1 & -1 & -1 & -1 & -1 & -1 & 1 & -1 & -1 & -1 & -1 & -1 & 1 & 1 & -1 & 1 & -1 & -1 \\
\hline 12 & 1 & -1 & -1 & -1 & -1 & -1 & 1 & -1 & -1 & -1 & 1 & -1 & 1 & 1 & 1 & 1 & -1 & -1 \\
\hline
\end{tabular}

Forrás: saját szerkesztés.

Megjegyzés: Az első oszlopban a sokk bekövetkezése óta eltelt negyedévek száma szerepel, míg a többiben az adott változó/sokk párhoz tartozó kumulált IVF-nek a minta második (1995Q1-2014Q4) és első (1975Q1-1994Q4) felére vonatkozó átlagaiból képzett különbség előjele. Ennek megfelelően „„” jelöli az adott negyedévi kumulált IVF értékének növekedését, ,,-1” pedig a csökkenését. A második sorban található S, AD, SD jelölések rendre a kínálati, aggregált keresleti, valamint specifikus keresleti sokkokat jelölik. 
20. táblázat: A Kalman-szürőből származó kumulált IVF-ek negyedéves értékeiből számolt lineáris trendparaméter előjele és szignifikanciája

\begin{tabular}{|c|c|c|c|c|c|c|c|c|c|c|c|c|c|c|c|c|c|c|}
\hline & \multicolumn{3}{|c|}{ CPI } & \multicolumn{3}{|c|}{ GDP } & \multicolumn{3}{|c|}{ GDPDEF } & \multicolumn{3}{|c|}{ PCE } & \multicolumn{3}{|c|}{ PPI } & \multicolumn{3}{|c|}{ Munkanélk. } \\
\hline & $S$ & AD & SD & $S$ & $A D$ & SD & $S$ & AD & SD & $S$ & $A D$ & SD & $S$ & AD & SD & $S$ & AD & SD \\
\hline 0 & 2 & -1 & 1 & 1 & 3 & 3 & 3 & -3 & -1 & 0 & 0 & -3 & -2 & 3 & 1 & 3 & 3 & -3 \\
\hline 1 & -3 & -3 & 1 & 1 & -1 & 3 & 3 & -3 & -1 & -3 & 0 & -2 & -3 & 3 & 0 & 3 & 0 & -3 \\
\hline 2 & -3 & -3 & 1 & 1 & -3 & 3 & -3 & -3 & -3 & -3 & 0 & -2 & -3 & 3 & 3 & 3 & 3 & -3 \\
\hline 3 & 3 & -3 & -1 & -3 & -3 & 3 & -3 & -3 & -3 & 2 & -3 & -3 & 3 & 3 & 0 & 3 & 2 & -3 \\
\hline 4 & 3 & -3 & -1 & 0 & -3 & 3 & -3 & -3 & 3 & 3 & -3 & -3 & 3 & 3 & 0 & 3 & -3 & -3 \\
\hline 5 & 3 & -3 & -3 & 3 & 0 & -3 & -3 & -3 & -3 & 3 & -3 & -3 & 3 & 3 & -3 & 3 & -3 & -3 \\
\hline 6 & 3 & -3 & -3 & 3 & 0 & -3 & 0 & -3 & -3 & 3 & -3 & -3 & 3 & 3 & -3 & 3 & -3 & -3 \\
\hline 7 & 3 & -3 & -3 & 3 & 0 & -3 & 3 & -3 & -3 & 3 & -3 & -3 & 3 & 3 & -3 & 3 & -3 & -3 \\
\hline 8 & 0 & -3 & -3 & 3 & 3 & -3 & 2 & -3 & -3 & -3 & -3 & -3 & 3 & 3 & -3 & 3 & -3 & -3 \\
\hline 9 & 0 & -3 & -3 & 3 & -3 & -3 & 2 & -3 & -3 & -3 & -3 & -3 & 3 & 3 & -3 & 3 & -3 & -3 \\
\hline 10 & 0 & -3 & -3 & 3 & -3 & -3 & 2 & -3 & -3 & -3 & -3 & -3 & 3 & 3 & -3 & 3 & -3 & -3 \\
\hline 11 & 0 & -3 & -3 & 3 & 0 & -3 & 0 & -3 & -3 & -3 & -3 & -3 & 3 & 3 & -2 & 3 & -3 & -3 \\
\hline 12 & 3 & -3 & -3 & 3 & 0 & -3 & 0 & -3 & -3 & -3 & -3 & -3 & 3 & 3 & 0 & 3 & -3 & -3 \\
\hline
\end{tabular}

Forrás: saját szerkesztés.

Megjegyzés: Az első oszlopban a sokk bekövetkezése óta eltelt negyedévek száma szerepel, míg a többiben az adott változó/sokk párhoz tartozó kumulált IVF-nek az „időbeli változása”. Inszignifikáns trendparaméter esetén 0 érték szerepel, $10 \%$ melletti szignifikanciánál 1/-1,5\%-osnál 2/-2, míg 1\%-osnál 3/-3. Az előjelet (és a színt) a trendparaméter előjele határozza meg: pozitív elmozdulásnál nullánál nagyobb, egyébként nullánál kisebb érték kerül a cellába. A második sorban található $\mathrm{S}, \mathrm{AD}, \mathrm{SD}$ jelölések rendre a kínálati, aggregált keresleti, valamint specifikus keresleti sokkokat jelölik. 
21. táblázat: Az időben lineáris trend szerint változó hatások indulóértékei

\begin{tabular}{|r|c|c|c|c|c|c|c|c|c|c|c|c|c|c|c|c|c|c|}
\hline & \multicolumn{4}{|c}{ CPI } & \multicolumn{3}{|c|}{ GDP } & \multicolumn{3}{c|}{ GDPDEF } & \multicolumn{3}{c|}{ PCE } & \multicolumn{3}{c|}{ PPI } & \multicolumn{2}{c|}{ Munkanélk. } \\
\cline { 2 - 7 } & S & AD & SD & S & AD & SD & S & AD & SD & S & AD & SD & S & AD & SD & S & AD & SD \\
\hline $\mathbf{0}$ & 1 & 0 & 1 & -2 & -1 & -1 & 1 & 2 & 1 & 1 & 1 & 1 & 1 & 1 & 0 & 0 & 0 & 1 \\
\hline $\mathbf{1}$ & 1 & 1 & 1 & -1 & 0 & -1 & 1 & 2 & 2 & 1 & 2 & 1 & 1 & 0 & 1 & 1 & 0 & 1 \\
\hline $\mathbf{2}$ & 1 & 1 & 1 & -1 & 0 & -1 & 1 & 2 & 2 & 1 & 2 & 1 & 1 & 1 & 0 & 0 & 0 & 1 \\
\hline $\mathbf{3}$ & 0 & 2 & 1 & 0 & 0 & -1 & 1 & 2 & 2 & 0 & 2 & 2 & 0 & 1 & 1 & 0 & 0 & 1 \\
\hline $\mathbf{4}$ & 0 & 2 & 1 & 0 & 0 & -1 & 1 & 2 & 2 & 0 & 2 & 1 & 0 & 1 & 1 & 0 & 0 & 1 \\
\hline $\mathbf{5}$ & 0 & 2 & 1 & 0 & 0 & 0 & 1 & 2 & 2 & 0 & 2 & 1 & 0 & 1 & 1 & 0 & 0 & 1 \\
\hline $\mathbf{6}$ & 0 & 1 & 1 & 0 & 0 & 0 & 1 & 2 & 2 & 0 & 2 & 2 & 0 & 1 & 1 & 1 & 0 & 1 \\
\hline $\mathbf{7}$ & 0 & 1 & 1 & 0 & 0 & 0 & 0 & 2 & 2 & 0 & 2 & 2 & 0 & 1 & 1 & 0 & 0 & 1 \\
\hline $\mathbf{8}$ & 0 & 1 & 1 & 0 & 0 & 0 & 0 & 2 & 2 & 0 & 1 & 1 & 0 & 1 & 1 & 0 & 0 & 1 \\
\hline $\mathbf{9}$ & 0 & 1 & 1 & 0 & 0 & 0 & 0 & 2 & 2 & 0 & 1 & 1 & 0 & 0 & 1 & 0 & 0 & 1 \\
\hline $\mathbf{1 0}$ & 0 & 1 & 1 & 0 & 0 & 0 & 0 & 2 & 2 & 0 & 1 & 1 & 0 & 0 & 1 & 0 & 0 & 1 \\
\hline $\mathbf{1 1}$ & 0 & 1 & 1 & 0 & 0 & 0 & 0 & 2 & 2 & 0 & 1 & 1 & 0 & 0 & 1 & 0 & 0 & 1 \\
\hline $\mathbf{1 2}$ & 0 & 1 & 1 & 0 & 0 & 0 & 0 & 2 & 2 & 0 & 1 & 1 & 0 & 0 & 1 & 0 & 0 & 1 \\
\hline
\end{tabular}

Forrás: saját szerkesztés.

Megjegyzés: Az első oszlopban a sokk bekövetkezése óta eltelt negyedévek száma szerepel, míg a többiben az adott változó/sokk párhoz tartozó kumulált IVF-nek a kezdő (1975Q1-es) értéke. Amennyiben a nulla nem esik bele a 1 standard hibányi intervallumba, akkor 1/-1, amennyiben a 2 standard hibányiba se, akkor 2/-2 szerepel a táblázatban (különben nulla). Az előjelet (és a színt) a paraméter előjele határozza meg: pozitív koefficiensnél nullánál nagyobb, egyébként nullánál kisebb érték kerül a cellába. A második sorban található $\mathrm{S}, \mathrm{AD}, \mathrm{SD}$ jelölések rendre a kínálati, aggregált keresleti, valamint specifikus keresleti sokkokat jelölik. A becslés során Newey-West féle heteroszkedaszticitás és autokorreláció robusztus standard hibákat használtam. 
22. táblázat: Az időben lineáris trend szerint változó hatások trendparaméterei

\begin{tabular}{|c|c|c|c|c|c|c|c|c|c|c|c|c|c|c|c|c|c|c|}
\hline & \multicolumn{3}{|c|}{ CPI } & \multicolumn{3}{|c|}{ GDP } & \multicolumn{3}{|c|}{ GDPDEF } & \multicolumn{3}{|c|}{ PCE } & \multicolumn{3}{|c|}{ PPI } & \multicolumn{3}{|c|}{ Munkanélk. } \\
\hline & $\mathbf{S}$ & $A D$ & SD & $S$ & $A D$ & SD & S & AD & SD & $S$ & $A D$ & SD & S & AD & SD & $S$ & $A D$ & SD \\
\hline 0 & 0 & 0 & 0 & 1 & 1 & 1 & -1 & -2 & -1 & -1 & 0 & 0 & -1 & 0 & 0 & 0 & 0 & -1 \\
\hline 1 & -1 & 0 & 0 & 0 & 0 & 2 & -1 & -2 & -1 & -1 & -1 & 0 & -1 & 0 & 0 & 0 & 0 & -1 \\
\hline 2 & -1 & -1 & 0 & 0 & 0 & 2 & -1 & -2 & -1 & -1 & -1 & 0 & -1 & 0 & 0 & 0 & 0 & -2 \\
\hline 3 & 0 & -1 & -1 & 0 & 0 & 1 & -1 & -2 & -1 & 0 & -1 & -1 & 0 & 0 & 0 & 0 & 0 & -2 \\
\hline 4 & 0 & -1 & 0 & 0 & 0 & 1 & -1 & -2 & -1 & 0 & -1 & -1 & 0 & 0 & 0 & 0 & 0 & -2 \\
\hline 5 & 0 & -1 & -1 & 0 & 0 & 1 & -1 & -2 & -1 & 0 & -1 & -1 & 0 & 0 & 0 & 0 & 0 & -1 \\
\hline 6 & 0 & -1 & -1 & 0 & 0 & 0 & -1 & -2 & -1 & 0 & -1 & -1 & 0 & 0 & 0 & 0 & 0 & -1 \\
\hline 7 & 0 & -1 & -1 & 0 & 0 & 0 & 0 & -2 & -1 & 0 & -1 & -1 & 0 & 0 & 0 & 0 & 0 & -1 \\
\hline 8 & 0 & -1 & -1 & 0 & 0 & 0 & 0 & -2 & -1 & 0 & -1 & -1 & 0 & 0 & 0 & 0 & 0 & -1 \\
\hline 9 & 0 & -1 & -1 & 0 & 0 & 0 & 0 & -2 & -1 & 0 & -1 & -1 & 0 & 0 & 0 & 0 & 0 & -1 \\
\hline 10 & 0 & -1 & -1 & 0 & 0 & 0 & 0 & -2 & -1 & 0 & -1 & -1 & 0 & 0 & 0 & 0 & 0 & -1 \\
\hline 11 & 0 & 0 & -1 & 0 & 0 & 0 & 0 & -2 & -1 & 0 & -1 & -1 & 0 & 0 & 0 & 0 & 0 & -1 \\
\hline 12 & 0 & 0 & 0 & 0 & 0 & 0 & 0 & -2 & -1 & 0 & 0 & -1 & 0 & 0 & 0 & 0 & 0 & -1 \\
\hline
\end{tabular}

Forrás: saját szerkesztés.

Megjegyzés: Az első oszlopban a sokk bekövetkezése óta eltelt negyedévek száma szerepel, míg a többiben az adott változó/sokk párhoz tartozó kumulált IVF időbeli változásának iránya és szignifikanciája. Amennyiben a nulla nem esik bele a 1 standard hibányi intervallumba, akkor 1/-1, amennyiben a 2 standard hibányiba se, akkor 2/-2 szerepel a táblázatban (különben nulla). Az elöjelet (és a színt) a kumulált trendparaméterek előjele határozza meg: pozitív koefficiensnél nullánál nagyobb, egyébként nullánál kisebb érték kerül a cellába. A második sorban található $\mathrm{S}, \mathrm{AD}, \mathrm{SD}$ jelölések rendre a kínálati, aggregált keresleti, valamint specifikus keresleti sokkokat jelölik. A becslés során Newey-West féle heteroszkedaszticitás és autokorreláció robusztus standard hibákat használtam.

\section{F.3.2. RMSE}

23. táblázat: 1 napos elörejelzések tekintetében az RMSE benchmarkot a legtöbb évben (3 alkalommal) meghaladó modellek

\begin{tabular}{|c|c|c|c|c|c|}
\hline Modell & Késleltetés & $\mathbf{2 0 1 1}$ & $\mathbf{2 0 1 2}$ & $\mathbf{2 0 1 3}$ & $\mathbf{2 0 1 4}$ \\
\hline ARX_S_F1 & 5 & 99,93 & 101,41 & 99,76 & 97,53 \\
\hline ARX_S_F2 & 5 & 99,86 & 101,08 & 99,92 & $\mathbf{9 8 , 2 9} * * *$ \\
\hline ARX_S_F3 & 5 & 99,94 & 101,09 & 99,99 & $\mathbf{9 8 , 8 3} * *$ \\
\hline ARX_S_F4 & 5 & 99,98 & 101,09 & 100,00 & $\mathbf{9 9 , 0 7} * *$ \\
\hline ARX_S_F1234 & 5 & 99,95 & 101,48 & 99,91 & 97,61 \\
\hline
\end{tabular}

Forrás: saját szerkesztés.

Megjegyzés: Az első oszlopban a modell neve (módszertan + típus ( $\mathrm{S}$ - spread, D - dlog) + magyarázó változók ( $F X$ - X „hónapos” futures, $B$ - benzin, $F$ - fütőolaj, MINDEN - 4 futures ill. benzin és fütőolaj spot)), a másodikban a késleltetések száma (p), a 3-6. oszlopokban pedig a benchmarkhoz képest elkövetett relatív RMSE értékek (\%) szerepelnek. A Clark-West teszt (Clark és West [2006]) alapján az adott évben 1, 5 és $10 \%$-os szinten szignifikáns eltéréseket $* * *, * *$ és * jelöli. Ugyanez érvényes a $24-25$. táblázatokra is. 
24. táblázat: 2 napos elörejelzések tekintetében az RMSE benchmarkot a legtöbb évben (3 alkalommal) meghaladó modellek

\begin{tabular}{|c|c|c|c|c|c|}
\hline Modell & Késleltetés & $\mathbf{2 0 1 1}$ & $\mathbf{2 0 1 2}$ & $\mathbf{2 0 1 3}$ & $\mathbf{2 0 1 4}$ \\
\hline ARX_S_F1 & 1 & 99,88 & 100,16 & 99,64 & 97,10 \\
\hline ARX_S_F1 & 2 & 99,88 & 100,11 & 99,68 & 97,06 \\
\hline ARX_S_F2 & 1 & 99,86 & 100,10 & 99,92 & $\mathbf{9 8 , 8 0 *}$ \\
\hline ARX_S_F2 & 2 & 99,87 & 100,03 & 99,98 & $\mathbf{9 8 , 7 5 ^ { * }}$ \\
\hline ARX_S_F3 & 1 & 99,91 & 100,13 & 99,99 & $\mathbf{9 9 , 3 9 *}^{*}$ \\
\hline ARX_S_F4 & 1 & 99,94 & 100,14 & 100,00 & 99,66 \\
\hline ARX_S_F1234 & 1 & 99,90 & 100,25 & 99,78 & 97,01 \\
\hline ARX_S_F1234 & 2 & 99,90 & 100,19 & 99,83 & 96,97 \\
\hline
\end{tabular}

25. táblázat: 3 napos előrejelzések tekintetében az RMSE benchmarkot a legtöbb évben (3 alkalommal) meghaladó modellek

\begin{tabular}{|c|c|c|c|c|c|}
\hline Modell & Késleltetés & 2011 & 2012 & 2013 & 2014 \\
\hline ARX_S_F1 & 1 & 99,78 & 100,16 & 99,85 & 97,52 \\
\hline ARX_S_F1 & 2 & 99,77 & 100,16 & 99,85 & 97,52 \\
\hline ARX_S_F1 & 3 & 99,85 & 100,47 & 99,87 & 97,44 \\
\hline ARX_S_F1 & 4 & 99,83 & 100,51 & 99,91 & 97,37 \\
\hline ARX_S_F1 & 5 & 99,93 & 100,69 & 99,54 & 97,59 \\
\hline ARX_S_F1 & 6 & 99,97 & 100,69 & 99,51 & 97,67 \\
\hline ARX_S_F1 & 7 & 99,86 & 100,89* & 99,49 & 97,87 \\
\hline ARX_S_F1 & 8 & 99,94 & 100,91 & 99,74 & 98,21 \\
\hline ARX_S_F1 & 9 & 99,94 & 100,91 & 99,76 & 98,22 \\
\hline ARX_S_F1 & 10 & 99,95 & 100,92 & 99,72 & 98,27 \\
\hline ARX_S_F1 & 11 & 99,97 & 100,91 & 99,68 & 98,32 \\
\hline ARX_S_F2 & 1 & 99,83 & 100,10 & 99,96 & 98,88* \\
\hline ARX_S_F2 & 2 & 99,83 & 100,10 & 99,96 & 98,88* \\
\hline ARX_S_F2 & 3 & 99,89 & 100,40 & 99,99 & 98,79 \\
\hline ARX_S_F2 & 5 & 99,97 & 100,63 & 99,65* & 98,95 \\
\hline ARX_S_F2 & 7 & 99,90 & 100,85 & 99,59 & 99,25 \\
\hline ARX_S_F2 & 8 & 99,98 & 100,87 & 99,85 & 99,60 \\
\hline ARX_S_F2 & 9 & 99,98 & 100,87 & 99,87 & 99,61 \\
\hline ARX_S_F2 & 10 & 99,99 & 100,87 & 99,83 & 99,67 \\
\hline ARX_S_F3 & 1 & 99,88 & 100,12 & 100,00 & $99,44 *$ \\
\hline ARX_S_F3 & 2 & 99,88 & 100,12 & 99,99 & 99,43* \\
\hline ARX_S_F3 & 7 & 99,95 & 100,87 & 99,61 & 99,85 \\
\hline ARX_S_F4 & 1 & 99,91 & 100,13 & 100,00 & 99,68 \\
\hline ARX_S_F4 & 2 & 99,91 & 100,13 & 100,00 & 99,68 \\
\hline ARX_S_F1234 & 1 & 99,80 & 100,17 & 99,88 & 97,28 \\
\hline ARX_S_F1234 & 2 & 99,80 & 100,17 & 99,88 & 97,27 \\
\hline ARX_S_F1234 & 3 & 99,88 & 100,48 & 99,90 & 97,14 \\
\hline ARX_S_F1234 & 4 & 99,85 & 100,52 & 99,94 & 97,07 \\
\hline ARX_S_F1234 & 5 & 99,96 & 100,71 & 99,58 & 97,28 \\
\hline ARX_S_F1234 & 7 & 99,89 & $100,92 *$ & 99,52 & 97,57 \\
\hline ARX_S_F1234 & 8 & 99,98 & 100,94 & 99,79 & 97,91 \\
\hline ARX_S_F1234 & 9 & 99,98 & 100,94 & 99,82 & 97,92 \\
\hline ARX_S_F1234 & 10 & 99,99 & 100,95 & 99,78 & 97,97 \\
\hline ARX_S_F1234 & 11 & 100,00 & 100,94 & 99,76 & 98,01 \\
\hline
\end{tabular}




\section{F.3.3. MAE}

26. táblázat: 1 napos elörejelzések tekintetében a MAE benchmarkot a legtöbb évben (3 alkalommal) meghaladó modellek

\begin{tabular}{|c|c|c|c|c|c|}
\hline Modell & Késleltetés & 2011 & 2012 & 2013 & 2014 \\
\hline $\mathbf{A R}(\mathbf{p})$ & 2 & 99,97 & 99,64 & 100,29 & 99,71 \\
\hline $\mathbf{A R}(\mathbf{p})$ & 3 & 99,83 & 99,81 & $101,04 *$ & 99,44 \\
\hline $\mathbf{A R}(\mathbf{p})$ & 5 & 99,32 & 100,92 & 99,79 & 98,82 \\
\hline ARX_S_BENZIN & 1 & 100,17 & 99,92 & 99,44 & 99,94 \\
\hline ARX_S_BENZIN & 2 & 100,08 & 99,95 & 99,68 & 99,72 \\
\hline ARX_S_BENZIN & 5 & 99,68 & 101,08 & 99,26 & 98,63 \\
\hline ARX_S_BENZIN & 7 & 99,58 & 101,72 & 99,99 & 98,72 \\
\hline ARX_S_FÜTŐOLAJ & 2 & 99,99 & 99,71 & 100,31 & 99,72 \\
\hline ARX_S_FÜTŐOLAJ & 3 & 99,86 & 99,79 & $101,02 *$ & 99,40 \\
\hline ARX_S_FÜTŐOLAJ & 5 & 99,31 & 100,96 & 99,78 & 98,81 \\
\hline ARX_S_B+F & 2 & 100,07 & 99,75 & 99,62 & 99,96 \\
\hline ARX_S_B+F & 5 & 99,67 & 100,96 & 99,12 & 98,99 \\
\hline ARX_S_B+F & 6 & 99,96 & 101,08 & 99,43 & 99,48 \\
\hline ARX_S_B+F & 7 & 99,48 & 101,51 & 99,92 & 99,16 \\
\hline ARX_S_F_ & 1 & 100,34 & 99,63 & 99,88 & 99,29 \\
\hline ARX_S_F2 & 5 & 99,83 & 100,95 & 99,57 & $98,32 *$ \\
\hline ARX_S_F3 & 1 & 100,24 & 99,62 & 99,92 & 99,44 \\
\hline ARX_S_F3 & 5 & 99,67 & 100,91 & 99,59 & $98,37 *$ \\
\hline ARX_S_F3 & 6 & 99,88 & 101,07 & 99,84 & 98,80 \\
\hline ARX_S_F4 & 1 & 100,19 & 99,61 & 99,93 & 99,55 \\
\hline ARX_S_F4 & 5 & 99,58 & 100,89 & 99,60 & $98,42 *$ \\
\hline ARX_S_F4 & 6 & 99,81 & 101,05 & 99,86 & 98,90 \\
\hline ARX_D_BENZIN & 1 & 100,04 & 99,40 & 99,97 & 99,96 \\
\hline ARX_D_F2 & 5 & 99,76 & 100,93 & 100,00 & 98,53 \\
\hline ARX_D_F3 & 1 & 100,04 & 99,59 & 100,00 & 99,92 \\
\hline ARX_D_F3 & 2 & 99,98 & 99,58 & 100,29 & 99,69 \\
\hline ARX_D_F3 & 3 & 99,89 & 99,72 & 101,14* & 99,35 \\
\hline ARX_D_F3 & 5 & 99,63 & 100,78 & 99,88 & 98,71 \\
\hline ARX_D_F4 & 1 & 100,03 & 99,56 & 99,97 & 99,92 \\
\hline ARX_D_F4 & 2 & 99,91 & 99,55 & 100,35 & 99,71 \\
\hline ARX_D_F4 & 3 & 99,76 & 99,65 & $101,06 *$ & 99,41 \\
\hline ARX_D_F4 & 4 & 99,83 & 99,76 & 101,04 & 99,41 \\
\hline ARX_D_F4 & 5 & 99,49 & 100,69 & 99,74 & 98,86 \\
\hline ARX_D_F4 & 6 & 99,54 & 100,88 & 99,99 & 99,29 \\
\hline
\end{tabular}

Megjegyzés: Az első oszlopban a modell neve (módszertan + típus $(\mathrm{S}$ - spread, D - dlog) + magyarázó változók ( $\mathrm{FX}-\mathrm{X}$,hónapos” futures, $\mathrm{B}$ - benzin, $\mathrm{F}$ - fütőolaj, MINDEN - 4 futures ill. benzin és fütőolaj spot)), a másodikban a késleltetések száma (p), a 3-6. oszlopokban pedig a benchmarkhoz képest elkövetett relatív MAE értékek (\%) szerepelnek. A Diebold-Mariano teszt (Diebold és Mariano [1995]) alapján az adott évben 1, 5 és 10\%-os szinten szignifikáns eltéréseket ***,** és * jelöli. Ugyanez érvényes a 27-28. táblázatokra is. 
27. táblázat: 2 napos előrejelzések tekintetében a MAE benchmarkot a legtöbb évben (4 alkalommal) meghaladó modellek

\begin{tabular}{|c|c|c|c|c|c|}
\hline Modell & Késleltetés & $\mathbf{2 0 1 1}$ & $\mathbf{2 0 1 2}$ & $\mathbf{2 0 1 3}$ & $\mathbf{2 0 1 4}$ \\
\hline ARX_S_BENZIN & 1 & 99,78 & 99,86 & 99,70 & 99,93 \\
\hline ARX_S_BENZIN & 2 & 99,89 & 99,70 & 99,78 & 99,83 \\
\hline
\end{tabular}

28. táblázat: 3 napos előrejelzések tekintetében a MAE benchmarkot a legtöbb évben (4 alkalommal) meghaladó modellek

\begin{tabular}{|c|c|c|c|c|c|}
\hline Modell & Késleltetés & $\mathbf{2 0 1 1}$ & $\mathbf{2 0 1 2}$ & $\mathbf{2 0 1 3}$ & $\mathbf{2 0 1 4}$ \\
\hline ARX_S_BENZIN & 1 & 99,55 & 99,96 & 99,72 & 99,83 \\
\hline ARX_S_BENZIN & 2 & 99,54 & 99,96 & 99,72 & 99,83 \\
\hline ARX_S_F1 & 1 & 99,95 & 99,86 & 99,93 & 98,10 \\
\hline ARX_S_F1 & 2 & 99,95 & 99,86 & 99,93 & 98,10 \\
\hline ARX_S_F1234 & 1 & 99,99 & 99,99 & 99,96 & $\mathbf{9 7 , 9 0 *}$ \\
\hline ARX_S_F1234 & 2 & 99,99 & 99,99 & 99,96 & $\mathbf{9 7 , 9 0}^{*}$ \\
\hline
\end{tabular}

Forrás: saját szerkesztés.

\section{F.3.4. Találati arány}

29. táblázat: 1 napos elörejelzések tekintetében a DA benchmarkot a legtöbb évben (4 alkalommal) meghaladó modellek

\begin{tabular}{|c|c|c|c|c|c|}
\hline Modell & Késleltetés & $\mathbf{2 0 1 1}$ & $\mathbf{2 0 1 2}$ & $\mathbf{2 0 1 3}$ & $\mathbf{2 0 1 4}$ \\
\hline AR(p) & 2 & $\mathbf{5 5 , 9 5 *}$ & 54,37 & 53,17 & 51,66 \\
\hline ARX_S_BENZIN & 2 & 53,97 & $\mathbf{5 3 , 5 7}$ & 55,56 & 51,18 \\
\hline ARX_S_F3 & 1 & 53,17 & $\mathbf{5 4 , 3 7} *$ & 55,95 & 55,45 \\
\hline ARX_S_F4 & 1 & 53,17 & $\mathbf{5 3 , 9 7} *$ & 56,35 & $\mathbf{5 6 , 4 0} *$ \\
\hline ARX_D_B+F & 2 & 54,37 & 54,37 & 53,17 & 50,24 \\
\hline ARX_D_F2 & 2 & 54,37 & 53,97 & 53,57 & 52,13 \\
\hline LPM_D_BENZIN & 4 & 53,17 & 53,57 & 53,57 & 51,66 \\
\hline LPM_D_MINDEN & 8 & 53,97 & 53,57 & 55,56 & $\mathbf{5 5 , 4 5}^{* *}$ \\
\hline LPM_D_MINDEN & 12 & 53,57 & 53,57 & 53,97 & $\mathbf{5 4 , 9 8}^{*}$ \\
\hline LPM_S_BENZIN & 1 & 53,97 & 53,57 & 53,57 & 50,24 \\
\hline LOGIT_D_B+F & 2 & 53,17 & 54,37 & 53,17 & 51,18 \\
\hline LOGIT_D_MINDEN & 8 & $\mathbf{5 5 , 9 5 *}$ & $\mathbf{5 4 , 7 6 *}$ & 56,35 & $\mathbf{5 7 , 3 5 * * *}$ \\
\hline LOGIT_D_MINDEN & 9 & 53,97 & 53,97 & 53,97 & $\mathbf{5 6 , 4 0} * *$ \\
\hline LOGIT_D_MINDEN & 10 & $\mathbf{5 6 , 3 5 *}$ & 54,37 & 53,17 & $\mathbf{5 5 , 4 5 *}$ \\
\hline LOGIT_D_MINDEN & 12 & 53,17 & 53,57 & 54,37 & $\mathbf{5 6 , 4 0} * *$ \\
\hline LOGIT_S_BENZIN & 1 & 53,97 & 53,57 & 53,57 & 50,24 \\
\hline SVM_S_F2 & 1 & 54,37 & 54,37 & 53,17 & 52,13 \\
\hline SVM_S_F3 & 1 & 54,76 & 54,37 & 53,17 & 50,24 \\
\hline
\end{tabular}

Forrás: saját szerkesztés.

Megjegyzés: Az első oszlopban a modell neve (módszertan + típus ( $\mathrm{S}$ - spread, D - dlog) + magyarázó változók (FX - X ,hónapos” futures, B - benzin, F - fütőolaj, MINDEN - 4 futures ill. benzin és fütőolaj spot)), a másodikban a késleltetések száma (p), a 3-6. oszlopokban pedig a találati arányok (\%) szerepelnek. A Pesaran-Timmermann teszt (Pesaran és Timmermann [1992]) alapján az adott évben 1, 5 és 10\%-os szinten szignifikáns eltéréseket ***,** és * jelöli. Ugyanez érvényes a 30-31. táblázatokra is. 
30. táblázat: 2 napos előrejelzések tekintetében a DA benchmarkot a legtöbb évben (4 alkalommal) meghaladó modellek

\begin{tabular}{|c|c|l|l|l|l|}
\hline Modell & Késleltetés & $\mathbf{2 0 1 1}$ & $\mathbf{2 0 1 2}$ & $\mathbf{2 0 1 3}$ & $\mathbf{2 0 1 4}$ \\
\hline AR(p) & 7 & 55,56 & 53,57 & 55,56 & 50,71 \\
\hline ARX_S_BENZIN & 6 & $\mathbf{5 5 , 5 6}^{*}$ & 50,79 & 54,76 & 54,03 \\
\hline ARX_S_BENZIN & 7 & $\mathbf{5 7 , 5 4 * *}$ & 51,98 & 54,37 & 53,55 \\
\hline ARX_S_BENZIN & 8 & $\mathbf{5 9 , 5 2 * * *}$ & 50,79 & 54,37 & 50,71 \\
\hline ARX_S_B+F & 5 & 53,97 & 51,59 & 55,16 & 50,24 \\
\hline ARX_S_B+F & 6 & 54,76 & 52,78 & 54,37 & 51,18 \\
\hline ARX_D_FÜTŐOLAJ & 3 & 53,17 & 50,79 & 54,76 & 52,13 \\
\hline ARX_D_F3 & 6 & 53,17 & $\mathbf{5 4 , 7 6 *}$ & 55,95 & 51,66 \\
\hline ARX_D_F1234 & 9 & 53,57 & 50,79 & 55,56 & 50,71 \\
\hline
\end{tabular}

Forrás: saját szerkesztés.

31. táblázat: 3 napos elörejelzések tekintetében a DA benchmarkot a legtöbb évben (3 alkalommal) meghaladó modellek

\begin{tabular}{|c|c|c|c|c|c|}
\hline Modell & Késleltetés & $\mathbf{2 0 1 1}$ & $\mathbf{2 0 1 2}$ & $\mathbf{2 0 1 3}$ & $\mathbf{2 0 1 4}$ \\
\hline ARX_S_BENZIN & 4 & 55,56 & 52,78 & $\mathbf{5 6 , 3 5}$ & 50,24 \\
\hline ARX_S_BENZIN & 5 & $\mathbf{5 8 , 7 3} * *$ & 53,17 & 54,76 & 45,50 \\
\hline ARX_S_F4 & 8 & $\mathbf{5 7 , 9 4 * *}$ & 53,17 & 50,00 & 51,66 \\
\hline ARX_S_F1234 & 18 & $\mathbf{5 6 , 7 5 *}$ & 52,78 & 46,43 & 51,18 \\
\hline ARX_D_MINDEN & 1 & 56,75 & 52,78 & 53,57 & 44,08 \\
\hline
\end{tabular}

Forrás: saját szerkesztés.

\section{F.3.5. Szelekciós eljárások}

32. táblázat: Illeszkedési mutatók (2011)

\begin{tabular}{|c|c|c|c|c|c|c|c|c|c|c|c|}
\hline & \multicolumn{3}{|c|}{ RMSE } & \multicolumn{3}{|c|}{ MAE } & \multicolumn{3}{|c|}{ DA } & \multirow[t]{2}{*}{ PROFIT } \\
\hline & & D1 & D2 & D3 & D1 & D2 & D3 & D1 & D2 & D3 & \\
\hline \multirow{7}{*}{ 号 } & OLS & 2,07 & 2,98 & 3,63 & $1,58 * * *$ & $2,25^{*}$ & 2,81 & $46,4 \%$ & $52,0 \%$ & $52,8 \%$ & $-6,5 \%$ \\
\hline & $\mathbf{N N}$ & 2,09 & 3,03 & 3,70 & $1,61 * * *$ & $2,30 * *$ & 2,84 & $50,4 \%$ & $47,6 \%$ & $52,4 \%$ & $10,3 \%$ \\
\hline & LPM & & & & & & & $48,0 \%$ & $50,0 \%$ & $52,4 \%$ & $-6,5 \%$ \\
\hline & logit & & & & & & & $47,6 \%$ & $49,6 \%$ & $54,0 \%$ & $-10,1 \%$ \\
\hline & NN_binary & & & & & & & $49,2 \%$ & $51,2 \%$ & $51,2 \%$ & $-3,0 \%$ \\
\hline & SVM_Y & & & & & & & $51,6 \%$ & $52,0 \%$ & $57,1 \%$ & $8,3 \%$ \\
\hline & SVM_D & & & & & & & $51,6 \%$ & $52,8 \%$ & $57,5 \% *$ & $30,9 \%$ \\
\hline \multirow{5}{*}{ 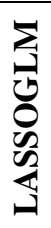 } & LPM & & & & & & & $52,0 \%$ & $51,2 \%$ & $54,8 \%$ & $26,8 \%$ \\
\hline & logit & & & & & & & $50,8 \%$ & $51,2 \%$ & $54,4 \%$ & $24,8 \%$ \\
\hline & NN_binary & & & & & & & $53,6 \%$ & $49,6 \%$ & $55,2 \%$ & $34,3 \%$ \\
\hline & SVM_Y & & & & & & & $53,2 \%$ & $46,0 \%$ & $48,0 \% *$ & $29,7 \%$ \\
\hline & SVM_D & & & & & & & $53,2 \%$ & $47,6 \%$ & $49,2 \%$ & $34,3 \%$ \\
\hline
\end{tabular}

Megjegyzés: a 32-35. táblázatok értelmezéséhez lásd a 18. táblázatot. 
33. táblázat: Illeszkedési mutatók (2012)

\begin{tabular}{|c|c|c|c|c|c|c|c|c|c|c|c|}
\hline & \multicolumn{3}{|c|}{ RMSE } & \multicolumn{3}{|c|}{ MAE } & \multicolumn{3}{|c|}{ DA } & \multirow[t]{2}{*}{ PROFIT } \\
\hline & & D1 & D2 & D3 & D1 & D2 & D3 & D1 & D2 & D3 & \\
\hline \multirow{7}{*}{ 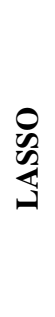 } & OLS & 1,51 & 2,01 & 2,40 & 1,13 & 1,53 & $1,82 * *$ & $50,0 \%$ & $52,0 \%$ & $48,4 \%$ & $-4,7 \%$ \\
\hline & NN & 1,52 & 2,01 & 2,44 & 1,14 & 1,53 & $1,86 * * *$ & $51,2 \%$ & $53,2 \%$ & $49,6 \%$ & $-7,7 \%$ \\
\hline & LPM & & & & & & & $53,2 \%$ & $50,4 \%$ & $55,6 \% *$ & $-1,5 \%$ \\
\hline & logit & & & & & & & $51,6 \%$ & $51,6 \%$ & $54,8 \%$ & $-7,7 \%$ \\
\hline & NN_binary & & & & & & & $52,8 \%$ & $50,8 \%$ & $54,4 \%$ & $-2,8 \%$ \\
\hline & SVM_Y & & & & & & & $48,0 \%$ & $50,4 \%$ & $52,0 \%$ & $-19,4 \%$ \\
\hline & SVM_D & & & & & & & $44,4 \% * *$ & $50,0 \%$ & $50,8 \% *$ & $-33,2 \%$ \\
\hline \multirow{5}{*}{ 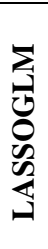 } & LPM & & & & & & & $52,4 \%$ & $55,6 \% * * *$ & $52,8 \%$ & $-6,2 \%$ \\
\hline & logit & & & & & & & $53,2 \%$ & $54,4 \% * *$ & $53,2 \%$ & $-2,1 \%$ \\
\hline & NN_binary & & & & & & & $52,0 \%$ & $52,4 \%$ & $52,0 \%$ & $-8,5 \%$ \\
\hline & SVM_Y & & & & & & & $46,8 \%$ & $52,0 \%$ & $52,0 \%$ & $0,0 \%$ \\
\hline & SVM_D & & & & & & & $42,5 \% * * *$ & $48,4 \%$ & $\begin{array}{c}56,7 \% * \\
*\end{array}$ & $-21,6 \%$ \\
\hline
\end{tabular}

34. táblázat: Illeszkedési mutatók (2013)

\begin{tabular}{|c|c|c|c|c|c|c|c|c|c|c|c|}
\hline & & \multicolumn{3}{|c|}{ RMSE } & \multicolumn{3}{|c|}{ MAE } & \multicolumn{3}{|c|}{ DA } & \multirow[t]{2}{*}{ PROFIT } \\
\hline & & D1 & D2 & D3 & D1 & D2 & D3 & D1 & D2 & D3 & \\
\hline \multirow{7}{*}{ 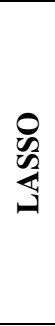 } & OLS & 1,16 & 1,69 & 2,12 & 0,92 & $1,32 * *$ & 1,68 & $49,2 \%$ & $50,0 \%$ & $54,8 \%$ & $3,8 \%$ \\
\hline & $\mathbf{N N}$ & 1,14 & 1,67 & 2,09 & 0,90 & 1,29 & 1,64 & $50,4 \%$ & $49,6 \%$ & $56,0 \% *$ & $5,9 \%$ \\
\hline & LPM & & & & & & & $52,8 \%$ & $51,6 \%$ & $54,0 \%$ & $13,3 \%$ \\
\hline & logit & & & & & & & $51,6 \%$ & $51,2 \%$ & $54,8 \%$ & $8,8 \%$ \\
\hline & NN_binary & & & & & & & $54,0 \%$ & $52,8 \%$ & $54,8 \%$ & $11,6 \%$ \\
\hline & SVM_Y & & & & & & & $52,8 \%$ & $51,6 \%$ & $50,8 \%$ & $4,9 \%$ \\
\hline & SVM_D & & & & & & & $52,4 \%$ & $49,6 \%$ & $49,6 \%$ & $8,5 \%$ \\
\hline \multirow{5}{*}{ 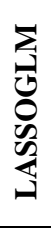 } & LPM & & & & & & & $53,6 \%$ & $49,2 \%$ & $53,2 \%$ & $14,6 \%$ \\
\hline & logit & & & & & & & $54,4 \%$ & $48,8 \%$ & $53,2 \%$ & $15,0 \%$ \\
\hline & NN_binary & & & & & & & $56,7 \% * *$ & $51,6 \%$ & $52,8 \%$ & $22,2 \%$ \\
\hline & SVM_Y & & & & & & & $51,2 \%$ & $45,6 \%$ & $45,6 \%$ & $4,4 \%$ \\
\hline & SVM_D & & & & & & & $51,6 \%$ & $43,7 \% * *$ & $45,6 \%$ & $-1,2 \%$ \\
\hline
\end{tabular}

35. táblázat: Illeszkedési mutatók (2014)

\begin{tabular}{|c|c|c|c|c|c|c|c|c|c|c|c|}
\hline & \multicolumn{3}{|c|}{ RMSE } & \multicolumn{3}{|c|}{ MAE } & \multicolumn{3}{|c|}{ DA } & \multirow[t]{2}{*}{ PROFIT } \\
\hline & & D1 & D2 & D3 & D1 & D2 & D3 & D1 & D2 & D3 & \\
\hline \multirow{7}{*}{ 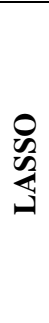 } & OLS & 1,25 & 1,69 & 2,04 & $0,95 * *$ & 1,33 & 1,64 & $52,1 \%$ & $47,9 \%$ & $45,5 \% * *$ & $-8,8 \%$ \\
\hline & NN & 1,24 & 1,65 & 1,93 & $0,93 *$ & 1,26 & 1,52 & $51,7 \%$ & $49,3 \%$ & $48,8 \%$ & $-13,4 \%$ \\
\hline & LPM & & & & & & & $52,6 \%$ & $44,1 \% *$ & $46,9 \%$ & $-5,6 \%$ \\
\hline & logit & & & & & & & $55,0 \%$ & $46,9 \%$ & $47,9 \%$ & $-1,7 \%$ \\
\hline & NN_binary & & & & & & & $50,7 \%$ & $45,5 \%$ & $49,8 \%$ & $-4,8 \%$ \\
\hline & SVM_Y & & & & & & & $46,0 \%$ & $45,5 \%$ & $47,4 \%$ & $-24,7 \%$ \\
\hline & SVM_D & & & & & & & $47,9 \%$ & $46,9 \%$ & $47,9 \%$ & $-15,0 \%$ \\
\hline \multirow{5}{*}{ 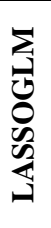 } & LPM & & & & & & & $56,9 \% * *$ & $47,9 \%$ & $48,8 \%$ & $-1,6 \%$ \\
\hline & logit & & & & & & & $56,9 \% * *$ & $46,4 \%$ & $46,4 \%$ & $-2,7 \%$ \\
\hline & NN_binary & & & & & & & $55,5 \% *$ & $47,9 \%$ & $49,8 \%$ & $-11,5 \%$ \\
\hline & SVM_Y & & & & & & & $47,9 \%$ & $48,8 \%$ & $43,1 \% *$ & $-20,2 \%$ \\
\hline & SVM_D & & & & & & & $51,7 \%$ & $47,9 \%$ & $46,0 \%$ & $-16,1 \%$ \\
\hline
\end{tabular}




\section{Hivatkozások}

Aguiar-Conraria, L. - Soares, M. J. [2011]: Oil and the macroeconomy: using wavelets to analyze old issues. Empirical Economics. Vol. 40. 3. sz. 645-655. old. DOI: http://dx.doi.org/10.1007/s00181-010-0371-x

Aguiar-Conraira, L. - Soares, M. J. [2014]: The Continuous Wavelet Transform: moving beyond uni- and bivariate analysis. Journal of Economic Surveys. 28. évf. 2. sz. 344-375. old. DOI: http://dx.doi.org/10.1111/joes.12012

Aleisa, E. - Dibooglu, S. [2004]: Oil Prices, Terms of Trade Shocks, and Macroeconomic Fluctuations in Saudi Arabia. Contemporary Economic Policy. 22. évf. 1. sz. 50-62. old. DOI: http://dx.doi.org/10.1093/cep/byh005

Alquist, R. - Kilian, L. [2010]: What do we learn from the price of crude oil futures? Journal of Applied Econometrics. 25. évf. 4. sz. 539-573. old. DOI: http://dx.doi.org/10.1002/jae.1159

Alquist, R. - Kilian, L. - Vigfusson, R. J. [2011]: Forecasting the Price of Oil. C.E.P.R. Discussion Paper. No. 8388. DOI: http://dx.doi.org/10.2139/ssrn.1911194

Anzuini, A. - Pagano, P. - Pisani, M. [2014]: Macroeconomic effects of precautionary demand for oil. Journal of Applied Econometrics. DOI: http://dx.doi.org/10.1002/jae.2419

Arezki, R. - Blanchard, O. [2014]: Seven Questions about the Recent Oil Price Slump. IMFdirect - The IMF Blog, December 22, 2014.

Atkeson, A. - Kehoe, P. J. [1999]: Models of Energy Use: Putty-Putty Versus Putty-Clay. American Economic Review. 89. évf. 4. sz. 1028-1043. old. DOI: http://dx.doi.org/10.1257/aer.89.4.1028

Badics, M. [2014]: Tőzsdei idösorok elörejelzése adatbányászati módszerekkel. Hitelintézeti szemle. 13. évf. 4. sz. 207-227. old.

Barsky, R. B. - Kilian, L. [2001]: Do We Really Know that Oil Caused the Great Stagflation? A Monetary Alternative. NBER Chapters, in: NBER Macroeconomics Annual 2001, 16. évf. 1. sz. 137-183. old. DOI: http://dx.doi.org/10.1162/088933601320224900

Barsky, R. B. - Kilian, L. [2004]: Oil and the Macroeconomy Since the 1970s. Journal of Economic Perspectives, American Economic Association. 18. évfolyam 4. sz. 115-134. old. DOI: http://dx.doi.org/10.1257/0895330042632708

Bashiri, B. N. - Manso, P. J. R. [2013]: Crude Oil Price Forecasting Techniques: A Comprehensive Review of Literature. DOI: http://dx.doi.org/10.2139/ssrn.2275428 
Baumeister, C. - Kilian, L. [2013]: Forecasting the Real Price of Oil in a Changing World: A Forecast Combination Approach. Bank of Canada Working Paper. No. 2013-28. Ottawa.

Baumeister, C. - Kilian, L. - Zhou, X. [2013]: Are Product Spreads Useful for Forecasting? An Empirical Evaluation of the Verleger Hypothesis. Bank of Canada Working Paper. No. 2013-25. Ottawa.

Baumeister, C. - Peersman, G. [2012]: The Role of Time-Varying Price Elasticities in Accounting for Volatility Changes in the Crude Oil Market. Journal of Applied Econometrics. 28. évf. 7. sz. 1087-1109. old. DOI: http://dx.doi.org/10.1002/jae.2283

Baumeister, C. - Peersman, G. [2013]: Time-Varying Effects of Oil Supply Shocks on the US Economy. American Economic Journal: Macroeconomics. 5. évf. 4. sz. 128. old. DOI: http://dx.doi.org/10.1257/mac.5.4.1

Baxter, M. - King, R. [1999]: Measuring business cycles: Approximate band-pass filters for economic time series. The Review of Economics and Statistics. Vol. 81. 4. sz. 575-593. old. DOI: http://dx.doi.org/10.1162/003465399558454

Benedictow, A. - Fjærtoft, D. - Løfsnæs, O. [2013]: Oil dependency of the Russian economy: an econometric analysis. Economic Modelling. 32. évf. 1. sz. 400428. old. DOI: http://dx.doi.org/10.1016/j.econmod.2013.02.016

Berk, R. A. [2008]: Statistical Learning from a Regression Perspective. Springer Series in Statistics. New York.

Berkowitz, J. - Kilian, L. [2000]: Recent developments in bootstrapping time series. Econometric Reviews. 19. évf. 1. sz. 1-48. old. DOI: http://dx.doi.org/10.1080/07474930008800457

Bernanke, B. S. [1983]: Irreversibility, Uncertainty, and Cyclical Investment. The Quarterly Journal of Economics, MIT Press. Vol. 98. 1. sz. 85-106. old. DOI: http://dx.doi.org/10.2307/1885568

Bernanke, B. - S. Gertler, M. [1995]: Inside the Black Box: The Credit Channel of Monetary Policy Transmission. Journal of Economic Perspectives, American Economic Association. 9. évf. 4. sz. 27-48. old. DOI: http://dx.doi.org/10.1257/jep.9.4.27

Bernanke, B. S. - Mark Gertler, M. - Watson, M. [1997]: Systematic Monetary Policy and the Effects of Oil Price Shocks. Brookings Papers on Economic Activity, Economic Studies Program, The Brookings Institution. 28. évf. 1. sz. 91-157. old. DOI: http://dx.doi.org/10.2307/2534702

Bjornland, H. C. [2000]: The dynamic effects of aggregate demand, supply and oil price shocks - A comparative study. The Manchester School. Vol. 68. 5. sz 578-607. old. DOI: http://dx.doi.org/10.1111/1467-9957.00220 
Bjornland, H. C. - Thorsrud, L. A. [2014]: What is the effect of an oil price decrease on the Norwegian economy? Working Paper. http://home.bi.no/a0310125/BT_OilPrice_2014.pdf

Blanchard, O. J. - Galí, J. [2007]: The Macroeconomic Effects of Oil Price Shocks: Why are the 2000s so different from the 1970s? NBER Chapters, in: International Dimensions of Monetary Policy, 373-421. old. DOI: http://dx.doi.org/10.3386/w13368

Bodenstein, M. - Guerrieri, L. [2011]: Oil efficiency, demand, and prices: a tale of ups and downs. International Finance Discussion Papers 1031. Board of Governors of the Federal Reserve System (U.S.).

Bodenstein, M. - Guerrieri, L. - Kilian, L. [2012]: Monetary Policy Responses to Oil Price Fluctuations. IMF Economic Review. 60. évf. 4. sz. 470-504. old. DOI: http://dx.doi.org/10.1057/imfer.2012.19

Bradley, P. C. - Polson, N.G. - Stoffer, D.S. [1992]: A Monte Carlo Approach to Nonnormal and Nonlinear State-Space Modeling. Journal of the American Statistical Association. Vol. 87. 493-500. old. DOI: http://dx.doi.org/10.1080/01621459.1992.10475231

Brooks, C. - Rew, G. - Alistair, S. - Ritson, S. [2001]: A trading strategy based on the lead-lag relationship between the spot index and futures contracts for the FTSE 100. International Journal of Forecasting. 17. évf. 1.sz. 31-44. old. DOI: http://dx.doi.org/10.1016/s0169-2070(00)00062-5

Brown, S. P. A. - Yücel, M. K. [2013]: The Shale Gas and Tight Oil Boom: US States' Economic Gains and Vulnerabilities. Council on Foreign Relations (October).

Christiano, L. J. - Fitzgerald, T. J. [2003]: The band pass filter. International Economic Review. 44. évf. 2. sz. 435-65. old. DOI: http://dx.doi.org/10.1111/14682354.t01-1-00076

Clark, T.E. - West, K. D. [2006]: Using out-of-sample mean squared prediction errors to test the martingale difference hypothesis. Journal of Econometrics. Vol. 135. 12. sz. 155-186. old. DOI: http://dx.doi.org/10.1016/j.jeconom.2005.07.014

Cristianini, N. - Shawe-Taylor, J. [2000]: An Introduction to Support Vector Machines and Other Kernel-based Learning Methods. First Edition. Cambridge University Press. Cambridge. DOI: http://dx.doi.org/10.1017/cbo9780511801389

Crowley, P. - Mayes, D. [2008]: How fused is the Euro area core? An evaluation of growth cycle co-movement and synchronization using wavelet analysis. OECD Journal: Journal of Business Cycle Measurement and Analysis. 4. évf. 1. sz. 6395. old. DOI: http://dx.doi.org/10.1787/jbcma-v2008-art4-en

Darvas, Zs. - Varga, B. [2014]: Inflation persistence in central and eastern European countries. Applied Economics. 46. évf. 13. sz. 1437-1448. old. DOI: http://dx.doi.org/10.1080/00036846.2013.875113 
Diebold, F. X. - Mariano, R. S. [1995]: Comparing predictive accuracy. Journal of Business and Economic Statistics. 13. évf. 3. sz. 253-263. old. DOI: http://dx.doi.org/10.1080/07350015.1995.10524599

Dhawan, R. - Jeske, K. [2008]: Energy Price Shocks and the Macroeconomy: The Role of Consumer Durables. Journal of Money, Credit and Banking. 40. évf. 7. sz. 1357-1377. old. DOI: http://dx.doi.org/10.1111/j.1538-4616.2008.00163.x

Edelstein, P. - Kilian, L. [2009]: How sensitive are consumer expenditures to retail energy prices? Journal of Monetary Economics. 56. évf. 6. sz. 766-779. old. DOI: http://dx.doi.org/10.1016/j.jmoneco.2009.06.001

Fattouh, B. - Kilian, L. - Mahadeva, L. [2013]: The Role of Speculation in Oil Markets: What Have We Learned So Far? The Energy Journal. 34. évf. 3. sz. DOI: http://dx.doi.org/10.5547/01956574.34.3.2

Fattouh, B. - Mahadeva, L. [2014]: Causes and Implications of Shifts in Financial Participation in Commodity Markets. Journal of Futures Markets. 34. évf. 8. sz. 757-787. old. DOI: http://dx.doi.org/10.1002/fut.21674

Feldstein, M. [2008]: The Dollar Hits an Oil Slick. Project Syndicate, 2008. május 23. http://www.project-syndicate.org/commentary/feldstein2/English

Fernandez, V. [2010]: Forecasting energy spot prices. Proceedings of the 4th International Conference on Mining Innovation. IV. fej. Mineral Economics and Finance. 271-278. old.

Feyrer, J. - Mansur, E. - Sacerdote, B. [2015]: Geographic Dispersion of Economic Shocks: Evidence from the Fracking Revolution. NBER Working Papers 21624, National Bureau of Economic Research. DOI: http://dx.doi.org/10.3386/w21624

Finn, M. G. [2000]: Perfect Competition and the Effects of Energy Price Increases on Economic Activity. Journal of Money, Credit and Banking. 32. évf. 3. sz. 400416. old. DOI: http://dx.doi.org/10.2307/2601172

Foufoula-Georgiou, E. - Kumar, P. [1994]: Wavelet Analysis in Geophysics: An Introduction. Wavelet Analysis and Its Applications. 4. évf. 1-43. old. DOI: http://dx.doi.org/10.1016/b978-0-08-052087-2.50007-4

Goncalves, S. - Kilian, L. [2004]: Bootstrapping autoregressions with conditional heteroskedasticity of unknown form. Journal of Econometrics, Elsevier. Vol. 123. 1. sz. 89-120. old. DOI: http://dx.doi.org/10.1016/j.jeconom.2003.10.030

Goupillaud, P. - Grossman, A. - Morlet, J. [1984]: Cycle-octave and related transforms in seismic signal analysis. Geoexploration. 23. évf. 1. sz. 85-102. old. DOI: http://dx.doi.org/10.1016/0016-7142(84)90025-5 
Green, E. J. - Porter, R. H. [1984]: Noncooperative Collusion under Imperfect Price Information. Econometrica, Econometric Society. 52. évf. 1. sz. 87-100. old. DOI: http://dx.doi.org/10.2307/1911462

Haidar, I. - Kulkarni, S. [2009]: Forecasting Model for Crude Oil Price Using Artificial Neural Networks and Commodity Futures Prices. International Journal of Computer Science and Information Security. 2. évf. 1. sz. 81-88. old.

Haidar, I. - Wolff, C. R. [2011]: Forecasting crude oil price. Proceedings of the 30th USAEE Conference.

Hamilton, J. D. [1988]: A Neoclassical Model of Unemployment and the Business Cycle. Journal of Political Economy, University of Chicago Press. 96. évf. 3. sz. 593617. old. DOI: http://dx.doi.org/10.1086/261553

Hamilton, J. D. [1994]: Time series analysis. Princeton University Press. Princeton.

Hamilton, J. D. [2003]: What is an oil shock? Journal of Econometrics, Elsevier. Vol. 113. 2. sz. 363-398. old. DOI: http://dx.doi.org/10.1016/s0304-4076(02)002075

Hamilton, J. D. [2009a]: Causes and Consequences of the Oil Shock of 2007-08. Brookings Papers on Economic Activity, Economic Studies Program, The Brookings Institution. 40. évf. 1. sz. 215-261. old. DOI: http://dx.doi.org/10.1353/eca.0.0047

Hamilton, J. D. [2009b]: Understanding Crude Oil Prices. The Energy Journal. 30. évf. 2. sz. 179-206. old. DOI: http://dx.doi.org/10.5547/issn0195-6574-ej-vol30no2-9

Hamilton, J. D. [2011]: Historical Oil Shocks. NBER Working Papers 16790, National Bureau of Economic Research. DOI: http://dx.doi.org/10.3386/w16790

Harris, F. J. [1978]: On the use of windows for harmonic analysis with the discrete Fourier transform. Proceedings of the IEEE. Vol. 66. 1. sz. 51-83. old. DOI: http://dx.doi.org/10.1109/proc.1978.10837

Hotelling, H. [1931]: The Economics of Exhaustible Resources. Journal of Political Economy. 39. évf. 2. sz. 137-175. old. DOI: http://dx.doi.org/10.1086/254195

Hudgins, L. - Friehe, C. - Mayer, M. [1993]: Wavelet transforms and atmospheric turbulence. Physics Review Letters. 71. évf. 20. sz. 3279-3282. old. DOI: http://dx.doi.org/10.1103/physrevlett.71.3279

IMF [2011]: Oil Scarcity, Growth and Global Imbalances. World Economic Outlook, International Monetary Fund, Washington D.C., 89-124. old.

IMF [2014]: Regional Economic Outlook. Statistical Appendix. Middle East and Central Asia Department. https://www.imf.org/external/pubs/ft/reo/2014/mcd/eng/pdf/menapst0514.pdf 
IMF [2015]: Regional Economic Outlook. Middle East and Central Asia. https://www.imf.org/external/pubs/ft/reo/2015/mcd/eng/pdf/menap1015.pdf

Jiménez-Rodríguez, R. - Sánchez, M. [2005]: Oil price shocks and real GDP growth: empirical evidence for some OECD countries. Applied Economics. 37. évf. 2. sz. 201-228. old. DOI: http://dx.doi.org/10.1080/0003684042000281561

Kang, S.H. - Kang S.M. - Yoon, S.M. [2009]: Forecasting Volatility of Crude Oil Markets. Energy Economics. 31. évf. 1. sz. 119-125. old. DOI: http://dx.doi.org/10.1016/j.eneco.2008.09.006

Kilian, L. [2008]: Exogenous Oil Supply Shocks: How Big Are They and How Much Do They Matter for the U.S. Economy? The Review of Economics and Statistics, MIT Press. 90. évf. 2. sz. 216-240. old. DOI: http://dx.doi.org/10.1162/rest.90.2.216

Kilian, L. [2009]: Not All Oil Price Shocks Are Alike: Disentangling Demand and Supply Shocks in the Crude Oil Market. American Economic Review. Vol. 99. 3. sz. 1053-1069. old. DOI: http://dx.doi.org/10.1257/aer.99.3.1053

Kilian, L. [2010]: Oil Price Shocks, Monetary Policy and Stagflation. RBA Annual Conference Volume, in: Renée Fry \& Callum Jones \& Christopher Kent (ed.), Inflation in an Era of Relative Price Shocks Reserve Bank of Australia.

Kilian, L. [2014]: Oil Price Shocks: Causes and Consequences. Annual Review of Resource Economics. 6. évf. 1. sz. 133-154. old. DOI: http://dx.doi.org/10.1146/annurev-resource-083013-114701

Kilian, L. - Lee, T. K. [2014]: Quantifying the speculative component in the real price of oil: The role of global oil inventories. Journal of International Money and Finance. Vol. 42. 71-87. old. http://dx.doi.org/10.1016/j.jimonfin.2013.08.005

Kilian, L. - Murphy, D. P. [2013]: The Role of Inventories and Speculative Trading in the Global Market for Crude Oil. Journal of Applied Econometrics. 29. évf. 3. sz. 454-478. old. DOI: http://dx.doi.org/10.1002/jae.2322

Kilian, L. - Park, C. [2009]: The Impact Of Oil Price Shocks On The U.S. Stock Market. International Economic Review, Department of Economics, University of Pennsylvania and Osaka University Institute of Social and Economic Research Association. Vol. 50. 4. sz. 1267-1287. old. DOI: http://dx.doi.org/10.1111/j.1468-2354.2009.00568.x

Knittel, C. - Pindyck, R. [2013]: The Simple Economics of Commodity Price Speculation. DOI: http://dx.doi.org/10.3386/w18951

Kriesel, D. [2007]: A Brief Introduction to Neural Networks. http://www.dkriesel.com 
Krugman, R. [1991]: Target zones and exchange rate dynamics. The Quarterly Journal of Economics. Vol. 106. 3. sz. 669-682. old. DOI: http://dx.doi.org/10.2307/2937922

Lanza, A. - Manera, M. - Giovannini, M. [2005]: Modeling and forecasting cointegrated relationships among heavy oil and product prices. Energy Economics. 27. évf. 6. sz. 831-848. old. DOI: http://dx.doi.org/10.1016/j.eneco.2005.07.001

Lee, K. - Shawn, N. - Ratti, R. [1995]: Oil Shocks and the Macroeconomy: The Role of Price Variability. The Energy Journal. 16. évf. 4. sz. 39-56. old. DOI: http://dx.doi.org/10.5547/issn0195-6574-ej-vol16-no4-2

Li, Z. - Zhao, H. [2011]: Not all demand oil shocks are alike: disentangling demand oil shocks in the crude oil market. Journal of Chinese Economic and Foreign Trade $\begin{array}{llllll}\text { Studies. } & 4 . & \text { évf. } & \text { sz. } 28-44 . & \text { old. DOI: }\end{array}$ http://dx.doi.org/10.1108/17544401111106798

Loungani, P. [1986]: Oil Price Shocks and the Dispersion Hypothesis. The Review of Economics and Statistics. 68. évf. 3. sz. 536-539. old. DOI: http://dx.doi.org/10.2307/1926035

Ma, T. - Liu, Z. - Zhou, Z. [2013]: Inhibition of Envelope Correction Method to EMD End Effect. Applied Mechanics and Materials. Vol. 347-350. 3940-3944. old. DOI: http://dx.doi.org/10.4028/www.scientific.net/amm.347-350.3940

MacKinnon, J. G. [1996]: Numerical distribution functions for unit root and cointegration tests. Journal of Applied Econometrics. 11. évf. 6. sz. 601-618. old. DOI: http://dx.doi.org/10.1002/(sici)1099-1255(199611)11:6\%3C601::aidjae417\%3E3.0.co;2-t

Mankiw, G. N. [1999]: Makroökonómia. Osiris Kiadó. Budapest.

Meinhold, R.J. - Singpurwalla, N.D. [1989]: Robustification of Kalman Filter Models. Journal of the American Statistical Association. Vol. 84. 479-486. old. DOI: http://dx.doi.org/10.2307/2289933

Mendoza, O. - Vera, D. [2010]: The Asymmetric Effects of Oil Shocks on an Oil-exporting Economy. Latin American Journal of Economics. Vol. 47. No. 135. 3-13. old. DOI: http://dx.doi.org/10.4067/s0717-68212010000100001

Merino, A. - Ortiz, A. [2005]: Explaining the So-called 'Price Premium' in Oil Markets. OPEC Energy Review. 29. évf. 2. sz. 133-152. old. DOI: http://dx.doi.org/10.1111/j.0277-0180.2005.00148.x

Milgrom, P. - Roberts, J. [1982]: Limit Pricing and Entry under Incomplete Information: An Equilibrium Analysis. Econometrica. Econometric Society. 50. évf. 2. sz. 443-459. old. DOI: http://dx.doi.org/10.2307/1912637 
Montana, G. - Triantafyllopoulos, K. - Tsagaris, T. [2009]: Flexible Least Squares for Temporal Data Mining and Statistical Arbitrage. Expert Systems with Applications. Vol. 36. 2. sz. 2. rész, 2819-2830. old. DOI: http://dx.doi.org/10.1016/j.eswa.2008.01.062

Mork, K.A. [1989]: Oil and the Macroeconomy when Prices Go Up and Down: An Extension of Hamilton's Results. Journal of Political Economy. 97. évf. 3. sz. 740-744. old. DOI: http://dx.doi.org/10.1086/261625

Mork, K. A. [1994]: Business Cycles and the Oil Market. The Energy Journal. 15. évf. 1. sz. 15-37. old. DOI: http://dx.doi.org/10.5547/issn0195-6574-ej-vol15-nosi-3

Naveau, P. - Genton, M. G. - Shen, X. [2005]: A skewed Kalman filter. Journal of Multivariate Analysis. Vol. 94. 2. sz. 382-400. old. DOI: http://dx.doi.org/10.1016/j.jmva.2004.06.002

Peersman, G. - Stevens, A. [2010]: Oil Demand and Supply Shocks: an Analysis in an Estimated DSGE-Model. http://www.qass.org.uk/2010-May_Brunelconference/Stevens.pdf

Peersman, G. - Van Robays, I. [2012]: Cross-country differences in the effects of oil shocks. Energy Economics. 34. évf. 5. sz. 1532-1547. old. DOI: http://dx.doi.org/10.1016/j.eneco.2011.11.010

Perotti, R. [2012]: The "Austerity Myth": Gain Without Pain? NBER Chapters, in: Fiscal Policy after the Financial Crisis. National Bureau of Economic Research. DOI: http://dx.doi.org/10.3386/w17571

Pesaran, M. H. - Timmermann, A. [1992]: A simple nonparametric test of predictive performance. Journal of Business and Economic Statistics. 10. évf. 4. sz. 461465. old. DOI: http://dx.doi.org/10.2307/1391822

Ramsey, J. - Lampart, C. [1998a]: Decomposition of economic relationships by time scale using wavelets. Macroeconomic Dynamics. 2. évf. 1. sz. 49-71. old.

Ramsey, J. - Lampart, C. [1998b]: The decomposition of economic relationships by time scale using wavelets: Expenditure and income. Studies in Nonlinear Dynamics and Econometrics. 3. évf. 1. sz. 23-42. old. DOI: http://dx.doi.org/10.2202/15583708.1039

Rotemberg, J. J. - Woodford, M. [1996]: Imperfect Competition and the Effects of Energy Price Increases on Economic Activity. Journal of Money, Credit and Banking. 28. évf. 4. sz. 549-577. old. DOI: http://dx.doi.org/10.2307/2078071

Rua, A. [2010]: Measuring comovement in the time-frequency space. Journal of Macroeconomics. 32. évf. 2. sz. 685-691. old. DOI: http://dx.doi.org/10.1016/j.jmacro.2009.12.005 
Rua, A. [2012]: Wavelets in economics. Economic Bulletin. Banco de Portugal. 18. évf. 2. $\quad$ sz. 71-79. old. https://www.bportugal.pt/enUS/BdP\%20Publications\%20Research/AB201208_e.pdf

Rua, A. - Nunes, L. C. [2009]: International comovement of stock market returns: A wavelet analysis. Journal of Empirical Finance. 16. évf. 4.sz. 632-639. old. DOI: http://dx.doi.org/10.1016/j.jempfin.2009.02.002

Rua, A. - Silva Lopes, A. [2014]: Cohesion within the euro area and the U. S.: a waveletbased view. OECD Journal: Journal of Business Cycle Measurement and Analysis. 10. évf. 2. sz. 63-76. old. DOI: http://dx.doi.org/10.1787/jbcma-20145js1j15792zp

Scott, S.L. - Varian, H.R. [2013]: Predicting the Present with Bayesian Structural Time Series. SSRN Journal. DOI: http://dx.doi.org/10.2139/ssrn.2304426

Scott, S.L. - Varian, H.R. [2013]: Bayesian Variable Selection for Nowcasting Economic Time Series. http://people.ischool.berkeley.edu/ hal/Papers/2012/fat.pdf

Shabri, A. - Samsudin, R. [2014]: Daily Crude Oil Price Forecasting Using Hybridizing Wavelet and Artificial Neural Network Model. Mathematical Problems in Engineering. DOI: http://dx.doi.org/10.1155/2014/201402

Silvapulle, P. - Mossa, A. [1999]: The relation between spot and future prices: Evidence from the crude oil market. The Journal of Futures Markets. 19. évf. 2. sz. 175193. $\quad$ old. DOI: http://dx.doi.org/10.1002/(sici)10969934(199904)19:2\%3C175::aid-fut3\%3E3.3.co;2-8

Smith, R. L. - Miller J. E. [1986]: A non-Gaussian state space model and application to prediction of records. Journal of the American Statistical Association. Series B. 48. évf. 1. sz. 79-88. old.

Statnikov, A. - Hardin, D. - Aliferis, C.F. [2006]: Using SVM Weight-Based Methods to Identify Causally Relevant and Non-Causally Relevant Variables. Proceedings of the Neural Information Processing Systems (NIPS) 2006 Workshop on Causality and Feature Selection.

Tang, L. - Hammoudeh, S. [2002]: An empirical exploration of the world oil price under the target zone model. Energy Economics. 24. évf. 6. sz. 577-596. old. DOI: http://dx.doi.org/10.1016/s0140-9883(02)00057-9

Tibshirani, R. [1996]: Regression Shrinkage and Selection via the Lasso. Journal of the American Statistical Association. Series B. 58. évf. 1. sz. 267-288. old.

Uliha, G. [2012]: Az olajár makrogazdasági hatásai: mitöl lett egyre gyengébb? Külgazdaság. 56. évf. 5-6. sz. 78-92. old.

Uliha G. [2015]: Rövid távú olajár-előrejelzések teljesitményének stabilitása. Statisztikai Szemle. 93. évf. 3. sz. 189-224. old. 
Uliha, G. [2016a]: Az olajár és a makrogazdaság kapcsolatának elemzése folytonos wavelet transzformáció segitségével. Megjelenés alatt (Statisztikai Szemle. 94. évf. 5. sz.).

Uliha, G. [2016b]: Az olajár gyengülő makrogazdasági hatásai: két versengö elmélet szintézise. Előkészületben.

Vapnik, V. N. [1995]: The nature of statistical learning theory. Second Edition. SpringerVerlag. New York. DOI: http://dx.doi.org/10.1007/978-1-4757-2440-0

Varga, Balázs [2011]: Időben változó változó együtthatójú ökonometriai modellek. Statisztikai Szemle. 89. évf. 7-8. sz. 813-838. old.

Varga, Balázs [2014]: Méri-e a tőkepiacok nyitottságát a beruházás és a megtakaritás időben változó kapcsolata? Statisztikai Szemle. 92. évf. 3. sz. 225-252. old.

Varian, H.R. [2014]: Big Data: New Tricks for Econometrics. Journal of Economic Perspectives. 28. évf. 2. sz. 3-28. old. DOI: http://dx.doi.org/10.1257/jep.28.2.3

Wang, S.Y. - Yu, L. - Lai, K.K. [2004]: A novel hybrid AI system framework for crude oil price forecasting. Lecture Notes in Computer Science. 3327. 233-242. old. DOI: http://dx.doi.org/10.1007/978-3-540-30537-8_26

Wang, G. C. S. - Jain, C. L. [2003]: Regression analysis - Modeling and Forecasting. Graceway Publishing Company. Great Neck.

Wooldridge, J. M. [2012]: Introductory Econometrics: A Modern Approach. Fifth Edition. South-Western Cengage Learning. Mason.

Xie, W. - Yu, L. - Xu, S. - Wang, S. [2006]: A new method for crude oil price forecasting based on support vector machines. International Conference on Computational Science (Part IV). 444-451. old. DOI: http://dx.doi.org/10.1007/11758549_63

Ye, M. - Zyren, J. - Shore, J. [2005]: A Monthly Crude Oil Spot Price Forecasting Model Using Relative Inventories. International Journal of Forecasting. 21. évf. 3. sz. 491-501. old. DOI: http://dx.doi.org/10.1016/j.ijforecast.2005.01.001

Ye, M. - Zyren, J. - Shore, J. [2006]: Forecasting Short-run Crude Oil Price Using High and Low Inventory Variables. Energy Policy. 34. évf. 17. sz. 2736-2743. old. DOI: http://dx.doi.org/10.1016/j.enpol.2005.03.017

Yousefi, S. - Weinreich, I. - Reinarz, D. [2005]: Wavelet-based prediction of oil prices. Chaos, Solitons and Fractals. 25. évf. 2. sz. 265-275. old.

Yu, L. - Wang, S.Y. - Lai, K.K. [2008]: Forecasting crude oil price with an EMD-based neural network ensemble learning paradigm. Energy Economics. 30. évf. 5. sz. 2623-2635. old. DOI: http://dx.doi.org/10.1016/j.eneco.2008.05.003 


\section{A szerző témában született publikációi}

Uliha, G. [2012a]: Az olajár makrogazdasági hatásai: mitől lett egyre gyengébb? Külgazdaság. 56. évf. 5-6. sz. 78-92. old.

Uliha, G. [2012b]: Az olajár gyengülö makrogazdasági hatásai: két versengő elmélet szintézise. VIII. KDI konferencia

Uliha G. [2014]: Olajár elörejelzések összehasonlitása. X. KDI konferencia

Uliha G. [2015]: Rövid távú olajár-elörejelzések teljesitményének stabilitása. Statisztikai Szemle. 93. évf. 3. sz. 189-224. old.

Uliha, G. [2016a]: Az olajár és a makrogazdaság kapcsolatának elemzése folytonos wavelet transzformáció segítségével. Megjelenés alatt (Statisztikai Szemle. 94. évf. 5. sz.).

Uliha, G. [2016b]: Az olajár gyengülő makrogazdasági hatásai: két versengő elmélet szintézise. Elökészületben. 